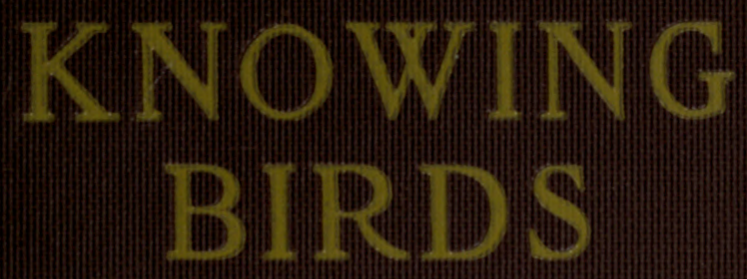

THROUGH STORIES

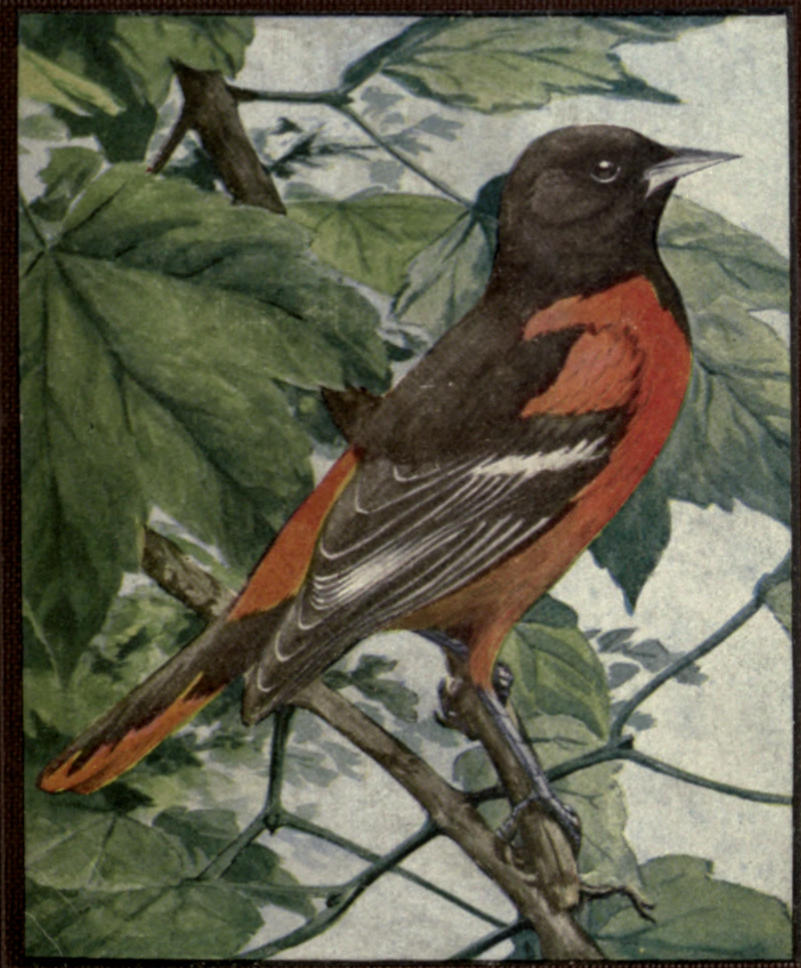

FLOYD BRALLIAR 


\section{GIFT Or}

A. F. Morrison

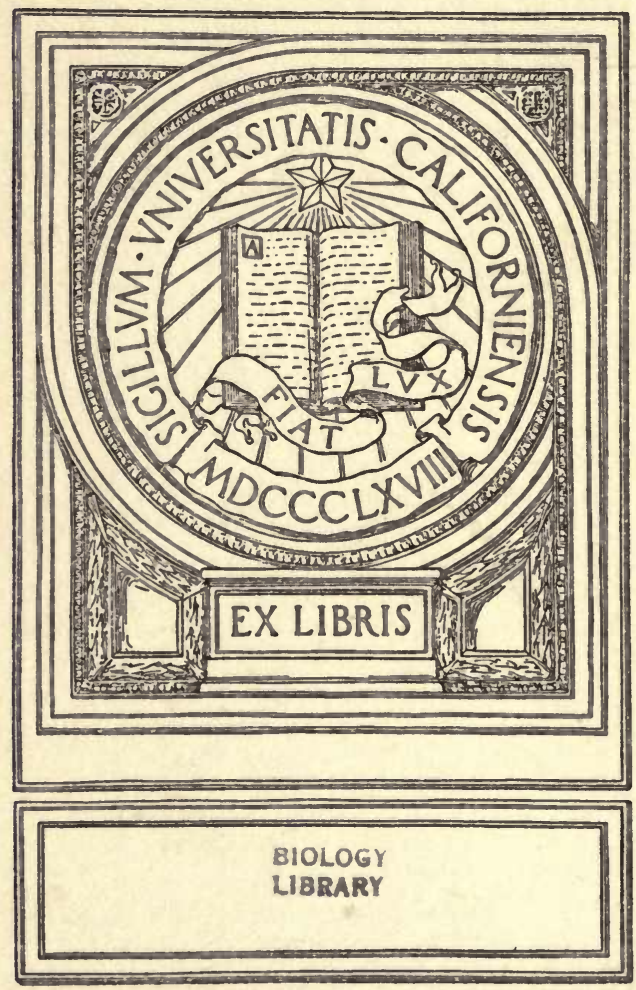






\section{KNOWING BIRDS THROUGH STORIES}




\section{By the same author \\ KNOWING INSECTS THROUGH STORIES}

IN this delightful work Mr. Bralliar delicately 1 reveals some of the most surprising truths about insect life in the plainest, simplest language; and in his characteristically attractive way of moulding his material into stories, he fascinates both the child and the adult reader.

The truly wonderful things the author tells about bees, butterflies, moths, grasshoppers, wasps, ants, flies, and other denizens of the woods and fields fairly astound: The butterfly with the thousand eyes, the worm with its handle and peculiar antecedence, hornets that make paper, the praying mantis that devours her husband, idiosyncrasies of Madam Doodlebug the murderess, marvellous physical power of the caddis fly in moving stones, the nations and kingdoms of ants, insects with air bladders on their feet, giant assassin bugs, fairy acrobats, the danger of mosquitoes and the dreaded housefly.

While pleasingly simple the book is scientifically accurate and forms an easy first course in natural history. With six color plates, eight half tones and text illustrations.

12mo. Cloth. S2s Pages. \$1.75, Net.

FUNK \& WAGNALLS COMPANY, Publishers 354-360 Fourth Avenue, New York 



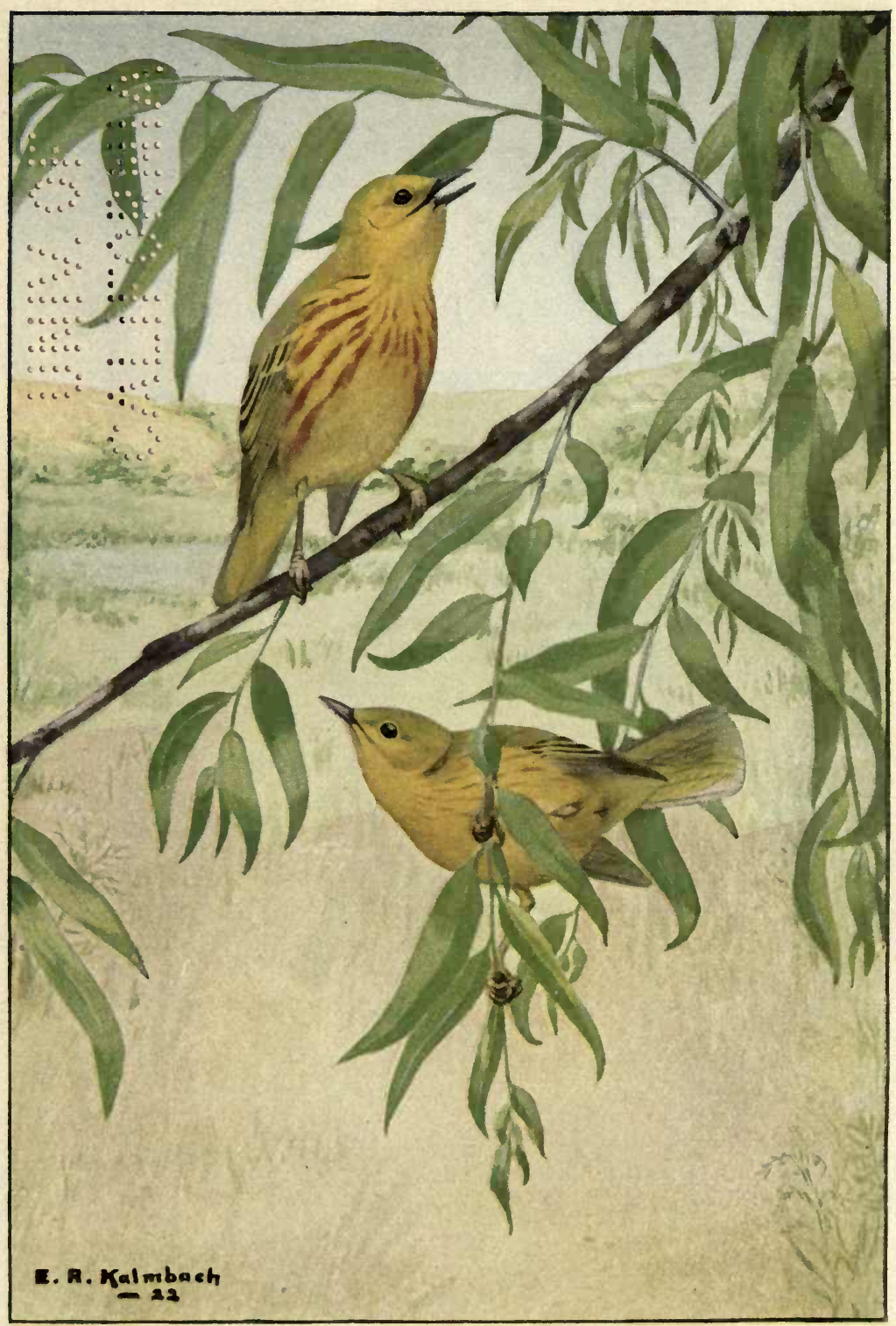




\section{Knowing Birds Through Stories}

BY

FLOYD BRALLIAR

AUTHOR OF

"KNOWING INSECTS THROUGH STORIES"

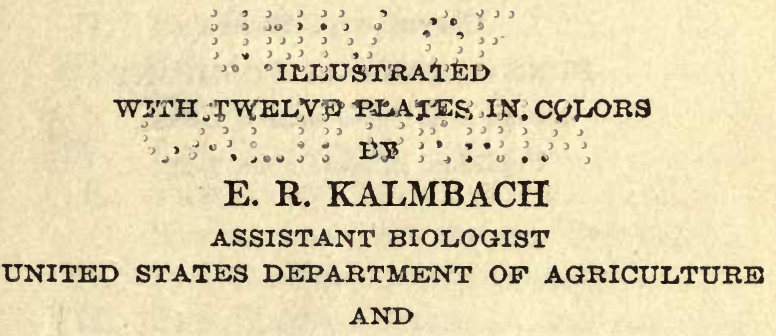

OTHER ILLUSTRATIONS IN BLACK-AND-WHITE

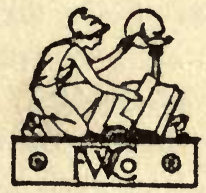

FUNK \& WAGNALLS COMPANY

NEW YORK AND LONDON 


\section{GIFT OF \\ A. F morerisol \\ - Coprriant, 1922, ș FUNK \& WAGNALLS COMPANY

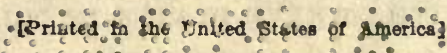 "Published in Norember, igé} of the Pan-Americen Republics ard the

Cnited States, August 11, 1910. 


\section{CONTENTS}

PAGE

Preface ......................... xi Key to the Orders of North American Birds... xiv CHAPTER

I. The Lesson a Goose Started..... 1

II. The Horned Grebe........... 5

III. The Great Diver............ 11

Key to Prgopodes ............ 17

IV. The California Gull.......... 18

V. The Black Tern............. 26

Key to Longipennes and Tubinares. 32

VI. The Double-crested Cormorant.... 33

VII. The White Fisher............ 37

Key to Steganopodes.......... 44

VIII. Johnnit Greenhead .......... 45

IX. Jimmy the Goose............. 59

X. LADY J JNE THE SWAN........... 65

XI. The SHITEPoKe ............ 75

Key to Herodiones ........... 80

XII. The Silent Dancer........... 81

XIII. The Sora RaIl.............. 88

XIV. The American Соot............ 93

Key to Palddicolez............ 97

XV. The KILLDEER .............. 98

Key to Lrmicol ............. 103

XVI. Lady BetTy's Husband.......... 104 
OHAPTER

XVII. ThB PratrIE Chicken........... 111

Key to Gallna............... 119

XVIII. Thв MoUnNing Dove ........... 120

XIX. THE TURKet BUzzard .......... 126

XX. The Bald Eagle ............. 132

XXI. Fleetwing the Sparrow HaWK. . . . . 137

XXII. Silmat Wrig the Great Horned Owl 144

KeY to Raptores ............. 156

XXIII. The Belted Kingfishar.......... 157

$\mathrm{Ker}$ to Coccyges .............. 166

XXIV. PicUs THE FLICKer............ 167

XXV. A Strange Nest............. 175

XXVI. The Chrmate Swift........... 181

XXVII. RUBYTHROAT .............. 188

KEY TO MACROCHIRES ........... 197

XXVIII. J JRRY THE KingBIRD. . . . . . . . . . 199

XXIX. SAM BLACK ................ 208

XXX. Тне ВовоцINк .............. 219

XXXI. The Grafter ................ 224

XXXII. THE Mradow LarK ............ 229

XXXIII. The HangING BIRD ............ 234

XXXIV. PETER the GoldFINCH........... 241

XXXV. The Song Sparrow ........... 247

XXXVI. THE TowHEE ............... 250

XXXVII. The Cardinal ............. 253

XXXVIII. The Indigo Bunting ........... 258

XXXIX. The Summer Tanager .......... 261

XL. Flygood aNd FleEtwing......... 265

XLI. The Cedar WaxwING .......... 275

XLII. The Butcher BIRD .......... 279

XLIII. The ReD-Eyed VIREo........... 284

XLIV. THE YELLOW WARBLER .......... 287 
CHAPTER

XLV. The Yellow-Breasted Chat ..... 290 XLVI. The Mocking Bird ............ 294 XLVII. Sally the House Wren.......... 300 XLVIII. The Brown Creeper............. 307 XLIX. Creepy the White-breasted Nut-

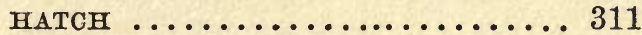

L. The Black-Capped Chickadee..... 316 LI. The Blue-Gray Gnatcatcher...... 320 LII. The Wood Thrush ........... 323 LIII. The AMERICAN Robin ......... 326 LIV. AzUre Wings the Bluebird........ 333 Ket to Passeres ............. 338 



\section{LIST OF ILLUSTRATIONS}

PAGE

PaIR of Yallow Warblers (In Colors).... Frontispiece FOOT OF THREE-TOEd WOODPECKER........... xiv Foot of Four-TOEd WoOdPECKER ........... xiv Horned Grebes with Nest (In Colors)........ 8 California Gulls Gathering Insects (In Colors) .. 20 Calmfornta Gulls .................... 24 OLd ANd Young RING-BILled GULls.......... 24

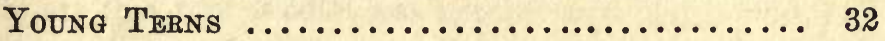
Young Double-Crested Cormorants ......... 32 Nests of Double-Crested Cormorants ........ 33 Fully Webbed Foot of One of the Staganopodes. 44 Male and Female Mallard............. 48 MaLlakd Drake ..................... 48 Canada Goose ......................... 48 The Trumpeter Swan (In Colors)......... 68 The Green Heron (In Colors) ............ 80 Pair of Sandhill Cranes at Home (In Colors).. 84 Nest and Young American Coot........... 96 Young KILLDEER ...................... 96 KILldeER and Nest..................... 97 Fоот оғ Соот..................... 97 MaLe Bobwhite....................... 108 Bobwhite's Nest . ..................... 108

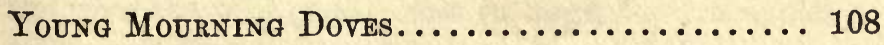
Pratrie Chickens (In Colors) .............. 116 Young TuRkey Buzzard................. 128 ix 
Sparrow Hawk Eating Mouse.............. 128

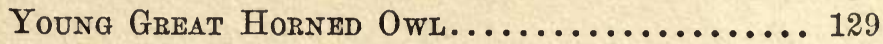

The Sparrow Hawk (In Colors)........... 140

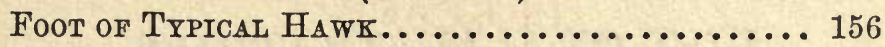

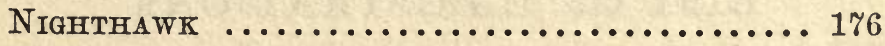

Nighthawk's Nest in Pasture............ 176

TaIL and Foot of Swift................. 198

The Baltimore Oriole (In Colots).......... 240

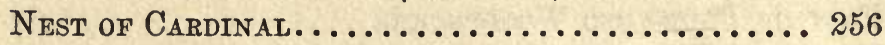

Pair of Indigo Buntings (In Colors) ......... 260

The Migrant Shrike (In Colors).......... 280

Yellow-Breasted Chats (In Colors) .......... 292

Head of Cardinal .................... 340 


\section{PREFACE}

W ${ }^{\text {HEN my father and his Southern bride came back }}$ from the Ozark country to his boyhood home in Southeastern Iowa and purchased a claim, their first thought was not of the crops their land could be forced to produce and the money they might make. When a site was selected for the new house it was located on the southern edge of a woodlot, ten acres of which were set aside as a playground. Possibly it would be more accurate to say that this woodlot was selected as a playground, and the house was located so as to be convenient. Be this as it may, because of their natural taste and pioneer training, great importance was attached to this plot, selected because of its location as well as the large variety of trees and plants that grew on it. Specimens of every additional wild plant and flower they could obtain were transplanted to this grove. It was fenced and the underbrush retained, except that here and there a specimen clump was removed, while only such stock as would do no harm were allowed to pasture there. Even those were kept out most of the year.

Like most pioneers, father was a great hunter, but in this grove nothing was ever allowed to be disturbed by the crack of a gun. There we children went to find the first bloodroot or anemone in the spring, and there we gathered the last black haws and wild grapes in the fall. Nowhere else were the wild gooseberries so large, the crabapples so yellow and fragrant, or the plums so red. Much of every Sabbath, when it was not raining, and every spare hour 
of the week between, we children spent in this grove. Best of all, father and mother were as anxious to go to "the grove" as any. of us; and when they did go, we children were always delighted, for there was sure to be a story, a bit of information, or a reminiscence connected with a tree or a flower.

With a stream of living water running through it, and the orchard, corn pens, barn, and cattle sheds on its border, it is small wonder that this grove became the haven for birds of every description, and many of them became so tame that they did not resent my assisting in their household affairs by furnishing prepared nesting material and by giving the babies an occasional treat of worms and bugs. It was here I learned to know and love the birds; and it is the story of some of these birds with a few others I have met elsewhere that I mean to tell in this book. I have traveled far and wide, but never have I seen any other place of nearly the same size that was inhabited by so many kinds of birds, or where they were so unconcerned when we were around. This grove was a haven for over thirty years, and doubtless several generations of birds taught their young that there they could find safety.

Hawks and crows were the only birds not allowed to nest there, and when they attempted to do so they were caught by setting a steel trap in their nest, as that would not disturb their neighbors. Like other children, we hunted birds' nests, and were always alert to see what our feathered friends were doing, but we did not take the eggs. Even to this day I have never made a collection of birds' eggs. To mother, a bird's nest was a sort of sanctuary, and I have never been able to get far enough from her training to regard it in any other light. 
In selecting the birds as subjects of the stories in this book, an attempt has been made not only to choose one or more from each of the important families but to select as far as possible those that are widely known in the United States. If, in telling the story of a bird, I do not mention the slightly different species of the same group, it is in order that the book may not become confusing to the reader. For this collection of stories is not intended to be a complete guide to the birds of America. It is hoped, however, that any boy or girl who reads the book may learn to what order any bird he or she sees belongs. To this end the keys are intended to be complete enough to enable him to identfy the family of most of the common birds.

The plan is the same as that of the author's "Knowing Insects Through Stories," and that book has been so kindly received by the public that it is hoped they will also like "Knowing Birds Through Stories."

I wish to acknowledge my indebtedness to Dr. Harry C. Oberholser for making the keys, reading the manuscript and offering many helpful suggestions; to A. F. Ganier, Frank G. Pellett, T. E. Musselman, H. S. Vaughn and A. H. Eastgate for lending photographs to be used for illustrations; and to Mr. E. R. Kalmbach for able work in drawing the colored illustrations. 


\section{Key to the Orders of North American Birds}

\section{WITH 3 TOES.}

TURINares-Albatrosses.

With 3 toes in front and tubular nostrils.

Pygopodes-Auks.

With 3 toes in front, nostrils not tubular, toes fully webbed, wings and tail short, and legs placed far behind the middle of body.

LONGIPENNES-Gulls.

With 3 toes in front, nostrils not tubular, toes fully webbed, wings and tail long, and legs placed near the middle of body.

IIMICOLA-Shore Birds.

Like LONGIPENNES but toes not fully webbed.

PrCI-Woodpeckers.

With 2 toes in front and one behind.

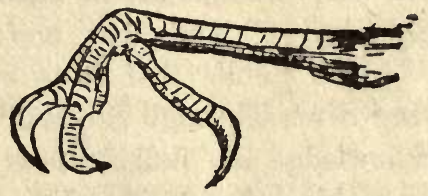

Foot of Three-toed Woopprcriz

\section{WITH 4 TOES.}

With 2 toes in front and 2 behind.

Psitraci-Parrots.

With a strongly hooked bill and unfeathered skin (cere) on the base of the upper mandible.

PICI-Woodpeckers.

With bill not strongly hooked and without a cere on the base of the upper mandible; bill chisel-like; tail stiff and its feathers pointed.

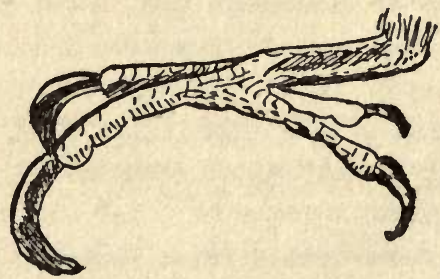

Foot of Four-toed Woopracrax 


\section{Coccyges.}

Bill not strongly hooked and without a cere, but rather long and somewhat hooked, and tail feathers not stiff or pointed.

With 3 toes in front and 1 behind.

Strganopodes-Pelicans, Cormorants, and their allies. All 4 toes connected by a web.

Only front toes fully webbed.

TuBinares-Petrels and Shearwaters. With tubular nostrils.

Anseres-Ducks and Geese.

Nostrils not tubular, and edges of bill more or less fringed or saw-like.

Pygopodes-Loons.

Like Anseres but edges of bill not fringed, tail short, and legs placed far back.

LONGIPENNES-Gulls and Terns.

Like Anseres but edges of bill not fringed, tail long, and legs placed near the middle of body.

Front toes not fully webbed.

Odon togLoss $x$-Flamingoes.

Bill bent abruptly downward at its middle; neck and legs long.

COLUMBE-Pigeons.

Bill not bent abruptly downward at its middle, the upper mandible with a soft cere, bill slightly if at all hooked; legs short.

RApTORES-Hawks and Owls.

Upper mandible with cere at base not soft, bill strongly hooked.

Pygopones-Grebes.

Upper mandible without naked skin (cere) at base; tail absent or practically 60 ; toes with lobes, or flaps.

HrRodiones-Herons.

Tail well developed, lower part of thighs naked, or bill long and grooved on each side; outer toe separate from the middle toe for its whole length; space around the eye and between the eye and the bill not feathered; neck and legs long.

Paludicols-Cranes, Rails, an Gallinules.

Like Herodiones but space around the eye and between the eye and the bill feathered; hind toe on the same level as the front toes, or else bird over 3 feet long.

LIMICoLe-Shore Birds.

Like Paludicole but hind toe short and inserted above the level of the front toes, or else bird not over 3 feet long.

Gallin $8-$ Gallinaceous Birds.

Lower portion of thighs feathered, or else the outer toe united to the middle toe for half its length; bill, if long, not grooved on the side; the hind toe elevated, or else the longest wing quill not twice as long 28 the secondaries.

Coccrges-Cuckoos.

Hind toe inserted on the same level as the front toes, and the outer toe united to the middle toe for half its length.

MACrochires-Goatsuckers, Swifts, and Hummingbirds.

The outer toe not united to the middle toe for half its length; tail feathers, 10.

Passeres-Perching Birds.

Similar to Macrochires but with 12 tail feathers. 



\section{I \\ THE LESSON A GOOSE STARTED}

WELL remember the first time I learned that any 1 two kinds of birds were more alike than any other two. It was a raw day early in March and my rheumatism did not allow me to be out of doors. Naturally this was a trial to me. It was raining in a desultory sort of way and there were great pools of water wherever there was not ice and slush. I was very impatient over the situation and was begging mother to let me go out of doors. Finally, her work done for the time, she came over and sat down by me and began to talk about the geese that were playing out in the water. I remember I asked why it was that they were having such a fine time while the chickens were standing around, as much disgruntled and disappointed with the weather as I. I could not see why the geese should be swimming and having just the best time possible while the chickens were humped up under the old hay shed, looking as if they had lost their last friend. I remember that while I felt sorry for the chickens, my sympathies were with the geese, and I longed to get out and paddle with them.

Presently an old goose stuck her head under the water and, kicking her feet up in the air, stood in this grotesque position for some moments while the water bubbled up around her neck. Mother explained that the geese belong: 
to the swimmers gind the they were feeding on plant roots and stems's and whatever else they could find under the wiatęr whieh live and pling in the: nater. She said they were especially fitted for this by the fact that they have a large amount of fat on their bodies under the feathers and skin, and that this keeps them from feeling the cold. This old goose was simply standing on her head while she chewed off some choice morsel of food under the water. She then explained that the swimmers have not only the ordinary feathers that all birds have but also a thick coat of down next to the skin, so that even though the outside feathers get wet this down keeps the water from getting to the skin. She told me that they also have a great deal of oil on their feathers and that this oil keeps the feathers from getting wet, as the feathers of a chicken do.

I was interested at once and began to ask questions about these swimmers, and learned that they all have webbed feet, altho the web is not the same on all of the different kinds. Moreover, many of them have a broad, flat bill, so that when feeding they can gather up a great mouthful of whatever they happen to find, and by sucking the water back and forth through this bill they can wash clean whatever is eatable before swallowing it. I learned that some of the swimmers have very small wings and spend nearly all of their time in the water, and can fly only when the wind is right. Still others have formed such a love for the water that they do not pretend to fly, and in consequence their wings have grown so small and weak that they could not fly if they tried. These birds of course live only on the shores of some large body of water, but none of them in our country. The swimmers are geese, ducks, swans, pelicans, sea-gulls, loons, etc. 
Mother told me that there is another large group of birds called waders. Unlike the swimmers they have very small or no webs on their feet and could not swim rapidly if they desired; but they have long legs and wade along the shores of rivers and streams catching frogs, minnows, and such things as come their way. Some have long necks as well, and so can get their food down deep in the water. Some of these waders also run over the land and use their long bills for picking up worms, insects, etc. The waders are the cranes, storks, snipes, sandpipers, herons, etc.

Next I learned about the birds of prey that have strong beaks with a hook on the end for tearing flesh. These birds all have powerful wings, so that they can fly long distances quickly. If it were not for these powerful wings they might not be able to catch their prey. Most of these birds, except owls, have a sharp hooked beak, and strong claws called talons which enable them to catch and hold their prey. Some of these birds live on dead animals, but even they have the hooked beak and the talons in order to tear their food into pieces. It is easy to recognize this group of birds by their beaks and talons. They are the hawks, vultures, and eagles.

"Did you ever notice," she said, "that on every bright, clear day the old hens get out and scratch in the dirt for their food and how they like to wallow in dust and ashes?" There is a great group of birds that have strong feet and legs with stout nails for doing just this sort of thing, and they are known as the scratchers. In this group come the quails, pheasants, turkeys, guineas, chickens, etc. They have plump heavy bodies and comparatively short stubby wings; and while they fly very rapidly they fly only short distances before alighting.

By this time I was so interested that I could be per- 
fectly happy sitting at the window, watching the birds, and trying to decide in my own mind which of the ones I saw belonged to these different groups. Mother promised that some other time she would tell me about the other great tribes of birds; but those groups contain so many birds and are so easy to distinguish one from another and from the other birds that this lesson has always been of great help to me in deciding to what family any particular bird belongs. I give it to you just as she gave it to me without mentioning the other groups of birds at this time. You will find it interesting and of great help to you to turn to the key in this book and pick out the different families of birds that come under each of these groups. Further on in the book you may learn about the other groups. 


\section{II}

\section{THE HORNED GREBE}

HAD a sister twelve or fourteen years older than I who 1 was teaching school on the other side of the river three or four miles from our place, and it was my job every Monday morning to ride behind her on a horse to her boarding place and then bring the horse back. One morning in May, as it had been raining heavily, my older brothers decided to go with us and see whether the river was over its banks, in the hope that they might be able to spear some fish. The Skunk River overflows its banks practically every spring, and at this time many large fish go out into the shallow water that spreads over the low bottoms and pass into the shallow ponds, for in such places they can get an abundance of food. At such times father and we boys used to take the old "gig" and often found little trouble in spearing fifty to one hundred pounds of fish within an hour or two.

On the way home when we reached Sellar's pond we noticed a duck, or at least what we supposed was a duck, in the middle of the pond. We promptly dismounted, tied our horses to the fence and ran over to the pond. As he went, Brother John filled his pockets with stones. Brother John was expert at throwing stones. Many a time I have seen him kill squirrels or birds in this way, and he hoped 
he might be able to get within throwing distance of this duck. Any one who knows anything about wild ducks knows that no duck would remain on the pond and allow a boy to come near enough to kill it with a stone, but any one who knows anything about boys also knows that boy would nevertheless make the attempt.

This bird remained about the middle of the pond and seemed to pay very little attention to us. The pond was not more than a hundred yards wide at the widest place so of course it was no trouble to get within throwing distance. John began throwing stones, but the bird paid no attention to him whatever except that every time a stone came so near that there was danger of being hit he would dive. Frequently the stone struck the place where this bird had been sitting only an instant before, but he was never there when the stone arrived. Presently he would come up fifty or a hundred feet away and was again ready to play his part in the game. After we had all thrown till our arms were completely tired, we decided to wade after this bird. My brother had decided by this time what the bird was, and said it was a "didipper."

Presently one of the neighbors came by and joined in the chase. We carried clubs and rocks and were determined that we would keep this bird under the water until he was so exhausted for breath that we would be able to catch him. For fully two hours we chased hither and thither, back and forth across the pond. Whenever the bird appeared we tried to surround him so that he could not dive past us. Then we would throw clubs and rocks, but even tho we were not more than fifteen or twenty feet away no one could throw quickly enough to hit this wonderful diver. Once he dived straight into my legs, but before I could 
make a move he was gone, and two or three times the other boys had the same experience. It was a most exciting chase, and of course we felt sure that if we persisted long enough we would be able to catch the poor bird. Finally the bird became too wary to come up and swim on the surface. Instead he would merely stick his bill out of the water so that he could breathe and there he would remain until some one spied him and threw at the beak. Finally we no longer attempted to throw, but endeavored to find his bill sticking out of the water and slip up to it quietly in the vain hope that the bird could not see with his eyes under water. It was very interesting to see how wary this bird finally became. He would stick his bill out of the water for a few moments and then without making the least ripple, would quietly sink beneath the surface and dive away to another place perhaps fifty or a hundred feet away, when just as noiselessly he would poke his beak above the water again. Altho we started the chase before nine o'clock, it was nearly noon before we finally gave up and started for home. We left because we could not find our bird any longer. I thought he had been under water till he had drowned, but when we were on our horses ready to start we looked back and there was our bird swimming about as tho nothing had happened.

When we reached home we had much to tell father and mother and were eager to know more of this bird. Father said that when a man attempts to shoot one of these birds, they often hit the place where it had been, but the bird sees the flash and manages to get under the water before the shot reaches him and for this reason they are the hardest of all swimmers to shoot. Of course this is not true with 
our modern guns which have no cap to flash. These birds do not even try to fly when hunted. In fact it is commonly believed that they can not fly. Some of the old hunters claim that they travel only by swimming or by waddling across country from pond to pond or from stream to stream. Father said he knew better than this because, in the early days of the country when they were much more abundant, he had seen them fly and was aware that they are very rapid flyers. They migrate the same as other birds do, and it is preposterous to suppose that a bird would travel hundreds of miles every year by swimming. He said that he had seen them rise into the air and fly away, starting from some bank or high place, and that they always started to fly directly into the teeth of the wind. He believed that on still days they can not rise. These birds are rather common throughout the Mississippi valley, often spending the winter where there is open water on the ponds or along the shores of the rivers.

In general appearance they look much like small ducks. I remember shooting one on the old crabapple pond one June. It was a beautiful bird, but I was surprized at its small size. These birds build their nests on floating vegetation found at the edge of a pond or along the shore of a stream and lead the little ones into the water when they are only a few hours old. They are perfectly harmless, feeding on snails, crawfish, etc., with grass and such other food as they can pick up about the ponds to supplement their menu. They are our most common representative of those birds whose wings are too small for ordinary flight, and so have adapted themselves to swimming and diving.

The old settlers claimed they could dive rapidly enough 


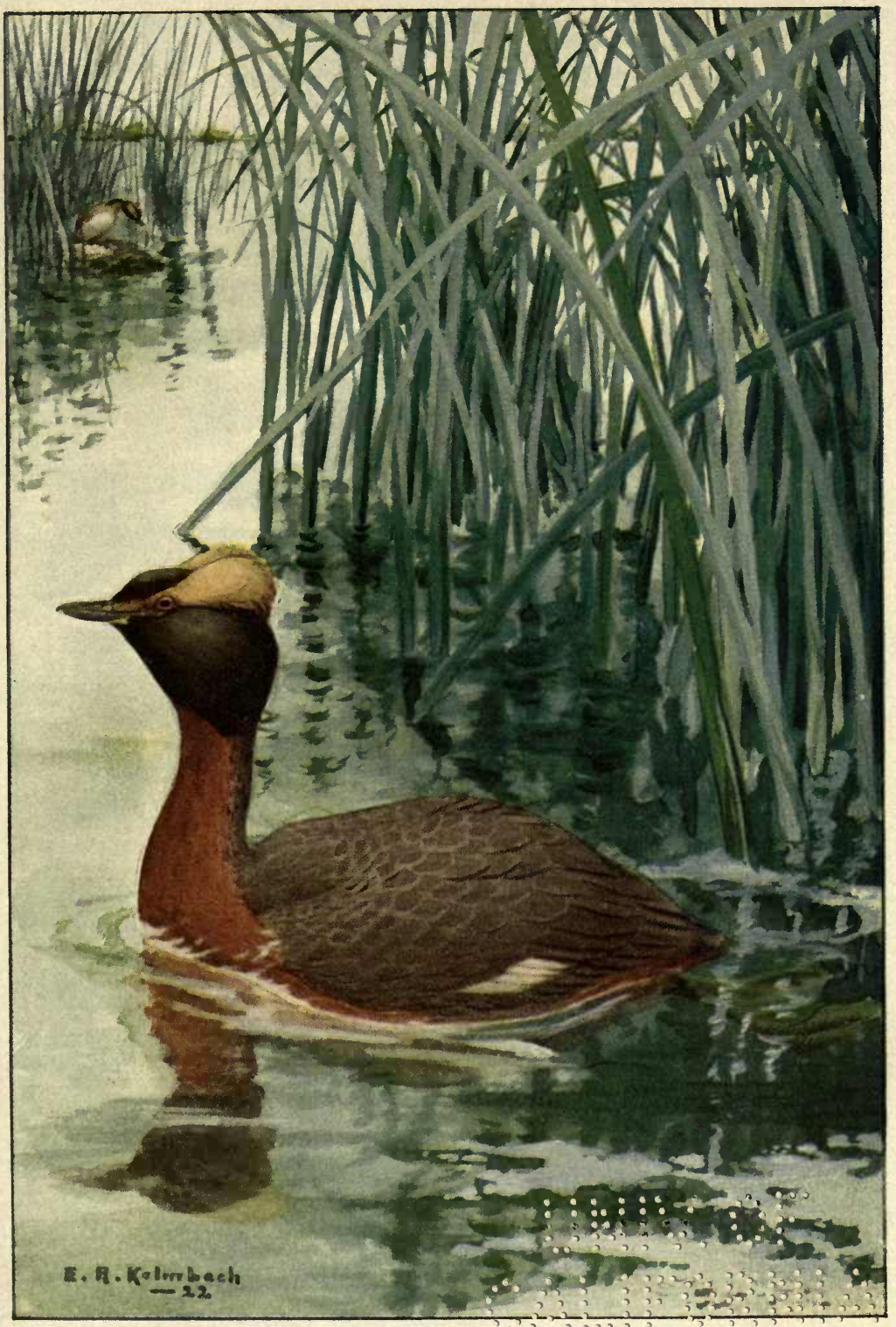



to catch fish under water. Whether this is true or not I do not know, but no bird with which I am acquainted is more expert at diving. They are usually found either solitary or in pairs; altho in my childhood it was not unusual to find flocks of a dozen or more. Now they are rare.

Some months ago my old father found one of these birds waddling about among the "buckbrush" on our school farm very near my house. Evidently it was migrating and for some reason or other had been forced to the ground. Here it was all but helpless, and father had no trouble in catching it. The poor creature had evidently been wandering about for hours, trying to reach water; but it was found more than a quarter of a mile from the Cumberland river, its nearest safety. Any bird or beast of prey passing that way would have found an easy breakfast. We kept it for a few hours, let the children see it, and then carried it off to the river. We attempted to feed it, but it refused all food and was perfectly delighted when it finally got its feet in the water. The first thing it did was to dive as far out from the shore as it could go, evidently still fearing that our intentions were to do it injury in spite of the fact that we had been its rescuers.

I have not told you that these birds were grebes. Grebes are queer looking birds. Their legs are set so far back that they walk almost straight up, as they have no tail. Few birds find it harder to walk, which probably accounts for this one's habit of nesting on a raft.

We have several kinds of grebes, but the horned variety is one of the most abundant species. It is called "horned" because in mating time the male develops brilliantly colored "horns" that are very conspicuous. Now they mostly 
nest north of the United States, tho formerly they nested as far south as Iowa. They visit us every fall and spring when migrating. The mother frequently carries her young on her back during the first few days of their life. She swims in and out among the rushes, catching tadpoles and small water bugs which she feeds to her young by jerking her head back over her shoulder so skillfully that she does not shake them from their perch. The male does not seem to take part in this feeding, tho he always remains near and seems very solicitous for his family's safety.

The young can swim as soon as they hatch, but some claim they must be taught to dive, and that the old bird teaches them to do this, when she thinks they are old enough, by the simple device of throwing them into the air by a quick flit of her wings. This is done in such a way as to throw them under the water head first, so there is nothing for them to do but to learn to dive. Whether this be true or not, they soon become as expert divers as their parents. 


\section{III}

\section{THE GREAT DIVER}

NE bright day early in June the great diver, with a kick and a sprawl, rolled out of his eggshell prison and rested for a time, and when his mother finally left the nest, opened his eyes, blinked painfully at the light, and as he gradually became accustomed to it began to notice his surroundings. He found himself lying in a nestlike depression on a heap of decaying moss and rushes in the shallow water, fifteen or twenty feet from the shore of a beautiful lake in Northern Maine. Of course he was not aware of this latter fact.

Tall green rushes, interspersed with the broken, brown, and blackened growth of the previous year, stood like a forest on all sides, but his nest heap was sufficiently elevated to allow him to look out over the expanse of the lake. He was more fortunately situated than many of his fellows who first see the light of day on the shores of our northern lakes, in that his parents had elected to build their home in the water. They had piled up two or three bushels of rushes, moss, and other vegetable matter and anchored them to the rushes in such a way that should the water rise the nest would float but could not leave its moorings, but should the water recede would rest on the muddy bottom 


\section{2}

\section{KNOWING BIRDS THROUGH STORIES}

and still be surrounded with abundance of water. This, soaking up through the bottom of the heap, would cause it to ferment and so make the nest always warm and snug. Many of their fellows elected to build by wallowing a depression in the earth near the edge of the water, and when their young hatched they found themselves in an apparently dangerous position, for many of the animals that hunt the shores of lakes would use them in the form of a good meal.

As the great diver gazed over the delightful expanse of water, at some distance he saw a handsome bird almost as large as a goose but with shorter neck, gliding over the surface of the water. Instinct told him that this was his mother. This bird had a black head and neck, while her black back and wings were heavily and irregularly spotted with white. Her belly and breast were whitish, tho he could not see much of this, for she swam so low that only the top of her back showed above the water.

At the other end of the lake a similar bird was diving and playing in the water. This was his father who, choosing to leave the feeding grounds near the nest to his busy wife, did his own fishing farther away. Suddenly the mother disappeared under the surface of the lake and presently arose with a fish in her mouth. Carrying this to the edge of the nest she proceeded to tear off strips of flesh and after thoroughly macerating these she placed them in the diver's mouth and he ate them greedily.

When his appetite was satisfied, his mother cleaned out the remaining pieces of egg shell from the nest, put her house in order and clambered on the nest to brood her off- 
spring and perchance hatch the other great brown egg that still remained in the nest. This egg was almost as large as a goose's egg, rather long in shape, and somewhat pointed at one end. It was chocolate brown, more or less marked and splashed with a deeper color. Only two had been laid in this nest, altho the common loon occasionally lays three eggs.

Presently, from the far end of the lake came a long laughing idiotic call, very much like the hysterical laugh of a lunatic, weird, wild, but not unmusical. The weather was warm, and recognizing this as the call of her mate, the mother slid into the water and swam rapidly down the lake to join him. With her wings tightly folded on her back she swam with long, alternating sweeps of her great webbed feet, making a speed that is possible to only a few of the swimming birds. Before she reached her lord, she noticed a young shiny trout in the clear water below and, diving, set chase. The startled trout, recognizing his danger, darted away with the utmost speed, but the great bird gained rapidly in spite of his exertions. Presently she caught him some six or eight feet under water and crunching his body two or three times gave him a quick twirl and catching him by the head swallowed him before she reached the surface.

Joining her lord they played about over the surface of the lake for some time, then, mindful of her baby, she returned to her brooding. Things ran along in this way for two or three days, when the great diver became impatient to get into the water; the mother loon, finding that the remaining eggs did not hatch, permitted him to do this. That night the little family rested together on 
the water near the edge of the lake. With the first gleam of dawn they were awake and their weird cries were echoing far and near. Soon the father bird raised himself straight up in the water facing the rising sun and began flapping his wings. Immediately his wife joined in his weird morning dance and the great diver, seeing his parents go through this ceremony, imitated them as best he could.

This was the regular morning ceremony with which they greeted the rising sun, and is an interesting characteristic of the loon. This ceremony over, the father departed to his feeding ground at the far end of the lake and the mother led the great diver to the shallow water near the nest.

One day soon after the diver had left the nest a man chanced to see him and his mother as they floated on the bosom of the lake. They were near the nest and the man pushed his canoe into the water so as to cut them off from the body of the lake. When the mother saw the man in his boat she gave a peculiar cry which the diver understood to be a danger cry. He promptly disappeared beneath the water and dived through the rushes away from the boat. His mother almost immediately dived and coming up a few yards on the other side of the boat, flapped the water with her wings and feet as loudly as possible to attract the man's attention. But the man knew something of birds and was not to be deceived by the mother; so keeping a keen eye on the water among the rushes he saw the baby loon rise to the surface, where he remained perfectly still. With two or three strokes of the paddle the boat glided toward the spot where he was hidden. The mother again uttered her warning cry and the 
great diver boldly dived out into the lake toward his mother. Again she dived and coming up very near the boat made a great splattering of the water to attract attention to herself.

Back and forth the chase continued for some time, when the great diver growing more wary dived into some brush that overhung the bank and rising just high enough to allow his nostrils to stick out of the water remained perfectly hidden.

The man was outwitted at last. He knew the bird was somewhere in the neighborhood doing this very thing, but could not locate him; so he gave up the chase and rowed down the lake. When he had rounded the point the mother loon uttered a low call and her son came to meet her. Swimming to him and letting her body down until only her head stuck out of the water she received him on her back and then rising to the surface swam rapidly down the lake. She swam, dived, and even caught fish with her young on her back, and so successfully was it done that he was not dislodged.

As the days went by, the loon family began to take an occasional flight. Loons cannot rise directly from the water as some ducks do, but run for a considerable distance over the surface, paddling with their feet, flapping their wings, and making great speed. Finally they are able to rise into the air. These three birds would race across the water as rapidly as possible, but when the parent birds rose the great diver was not able to follow. Disconsolate he watched them fly away and when after a time they returned and plunged into the lake with terrific force he was overjoyed. Loons have very heavy bodies and comparatively short wings and so find it hard to rise from the 
water, but when they succeed in taking flight they fly with great rapidity. They are not able to check their speed much and still remain in the air. When ready to alight, they circle over the water getting lower each time until finally they often plunge in with almost the velocity of an express train, making a tremendous noise and half run, half swim, for a considerable distance before they are able to stop.

Within another week the great diver was able to take to the air himself, and then he accompanied his parents on their daily excursions. In the meantime he had learned to be almost as expert in diving and fishing as his parents.

One day he accompanied them on a prolonged trip to the sea shore. While he was fishing his parents disappeared, he knew not where. At first he was lonely, but he soon discovered many young birds like himself fishing in the same region and made friends with them. These birds soon learned to wander far out at sea, sometimes gathering in large flocks at night to sleep on the surface of the ocean. However, they preferred to sleep on the shore.

As the weather grew colder, one after another departed for the Southland, and one day the great diver went also. After spending the winter fishing in the lakes and on the coast of Florida he selected a mate with whom he flew to the Northland, and seeking out a lake that was not already occupied by loons set up housekeeping for himself.

There are several kinds of loons, all of which are much alike in their habits. They breed from the northern part of the United States to Alaska. They love solitude, so seldom more than one pair nest in a lake unless it be a large one. They seem not to breed as far South as they did in 
my boyhood days, but are often seen migrating over much of the country, and are to be seen at some time of the year on most of the larger streams of the United States.

Aside from the common loon we have the yellow-billed loon, the Pacific loon, and the red-throated loon. They are such skilled divers that it takes a very good marksman indeed to shoot one, though they practically never fly when pursued. Occasionally loons stay in the north too long, and a sudden cold spell freezes so much ice on the borders of their lake that they have no room to run on the water far enough to take flight so they must stay where they are. Finally the lake freezes over and they starve to death.

\section{COLYMBIDE-Grebes.}

\section{Key to the Families of Pygopodes} Without a tail and with lobed feet.

Alcros-Guillemots, Aüks, and Marres.

With a tail and with webbed feet, but with no hind toe.

GaviIDE-Loons.

With a tail, webbed feet, and with a hind toe. 


\section{IV}

\section{THE CALIFORNIA GULL'}

$\mathrm{N}$ the fall of $189 \%$ I went to Provo City, Utah, and spent
something like two years in teaching. Having always been a lover of gardening and farming, the next spring in partnership with a friend I rented a piece of land not far from the city for gardening, since I could do this without interfering with my teaching, especially as the heavy part of the gardening work would come during the summer vacation. Along in April I hired a team and went to plow this land. About ten o'clock the first forenoon I was surprized to see a large flock of white birds approaching. In a moment they were alighting on all sides, squealing, running over the plowed ground, and having a good time in general. As long as I plowed in this field these birds remained. At times a few would fly away, but others were always coming to take their places. Before long there were two or three hundred of these birds in the field, fussing and quarreling over every bug and worm my plow turned up. They were so anxious to get these worms that they would fly ahead of the plow and sit as close as they possibly could until I passed them. Sometimes when a worm showed in the furrow I have had a gull jump in just ahead of the turning soil and would feel sure it would be plowed under, but some way it always managed to get out just in 
the nick of time. They were in the furrow behind, on the plowed ground ahead, and on all sides, hunting and pecking about constantly, and every one chirping or squealing until the field was noisier than a barnyard at feeding time.

These birds seem a little larger than the ordinary domestic duck, but not so large as the largest Peking ducks I have seen. Their bodies are much more graceful than the body of a duck and they have much longer wings and shorter necks; altho the bill is rather broad at the base, it is not flat like a duck's bill but comes almost to a point and has a decided hook at the end much like the beak of a hawk. They were bluish gray over the back and white on the breast, the belly, and the quills of the tails. I had seen gulls before far out on Lake Michigan, tho they were not like these; and I had read enough to know at once that they were sea gulls of some kind. I was surprized to find so many sea gulls a thousand miles from the ocean, but learned that they visit this part of the country regularly every spring by the tens of thousands on their way to their nesting grounds farther north. Sometimes a few stay in Utah and nest there.

They are considered a great blessing in Utah, because they stay until after most of the grasshoppers are hatched and destroy them by the tens of thousands. The old settlers will tell you how in the early days the grasshoppers, really the black crickets, were destroying all the crops, when one April day in 1850, just as these insects were hatching by millions, the gulls came in flocks, and de, roured them and saved the country. They will tell you that they eat grasshoppers until they are gorged and then fly to the lake or some stream and drink themselves full of water when they disgorge the grasshoppers they have 
eaten and then go back and eat more. I know that they eat grasshoppers for awhile and then fly to the water; but there is no reason for believing that they lose their grasshoppers after drinking. None that I have ever watched lost any. I presume the idea is obtained from the fact that they eat so much that people who knew little of the birds thought it impossible that they digested all.

As the season advances most varieties of sea gulls fly to Northern United States and northward, where they nest on barren islands. Those who have seen their nesting places say that they have often found thousands of nests on a space of only an acre or two. It is when these birds are going to their nesting grounds that we sometimes see them flying over the central States. I have frequently seen them in Iowa and Nebraska, but have never known them to stay any length of time. In fact, they seldom alight in those States except where there are lakes. Some species nest on the coast of Washington and Oregon, some on our Atlantic coast, while a few nest inland.

But I had never had an opportunity to know much about sea gulls at home until my first visit to Seattle, Washington. There they are to be found by thousands, especially from early autumn until late spring. When they were coming in from their breeding grounds in the autumn I have seen them arrive by thousands every day. Each morning it was plain that there were many more than the day before, and for an hour or two before dark they arrived in a seemingly endless stream. There are many varieties of sea gulls, but the habits of all are much the same and for the purpose of this story it is not necessary to tell the differences. We have twenty-two species in the United States. Those of you who live where sea gulls 


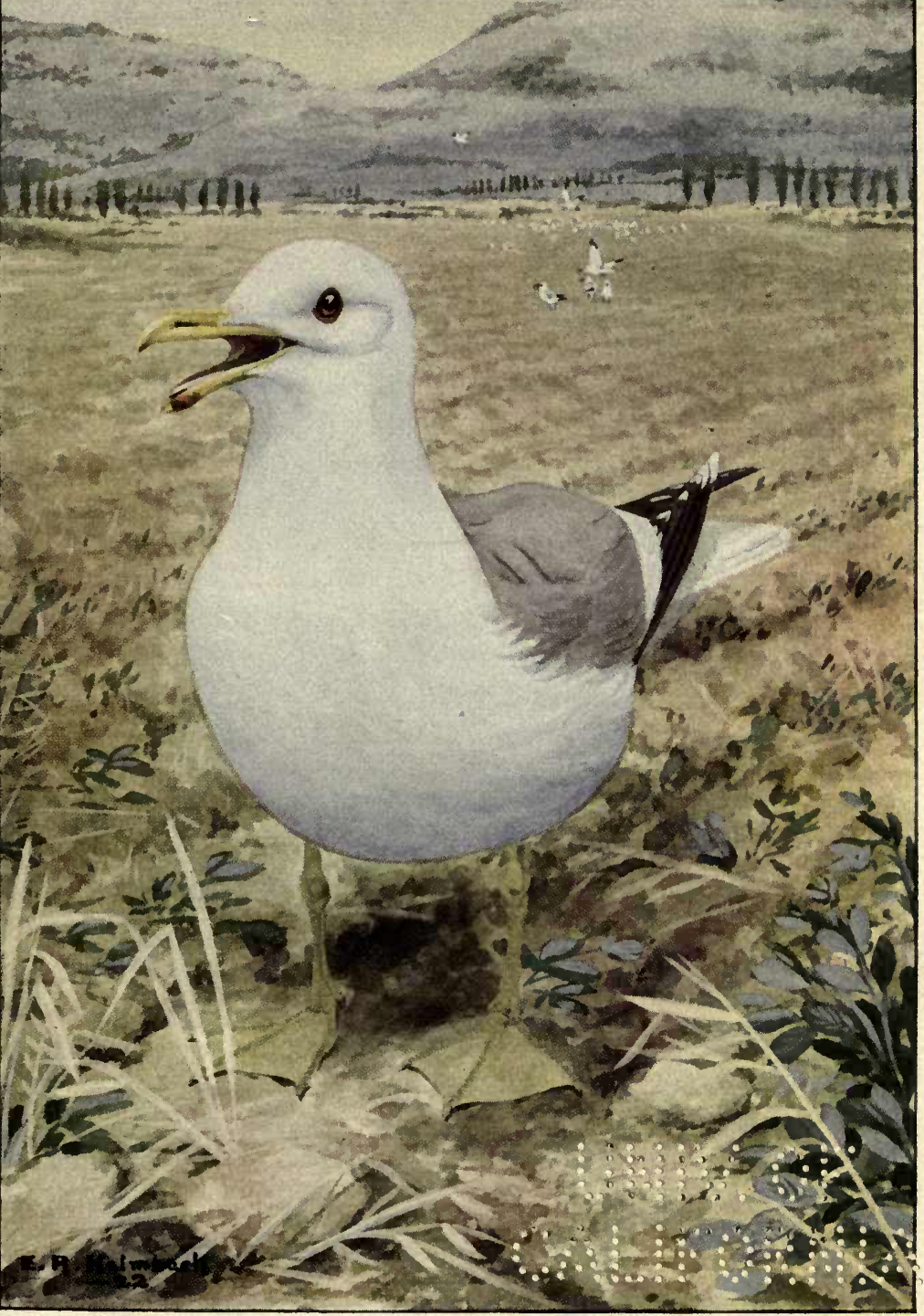




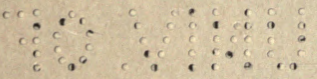

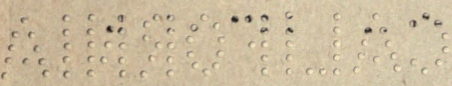


are plentiful and wish to know how to recognize the different kinds can obtain a government bulletin on gulls that will enable you to identify at least the most common ones. The greater part of the readers of this book are located where sea gulls are not common and for this reason they will not be interested in knowing much about the different kinds.

The gulls are great lovers of the water, and are known as sea gulls because they frequent the shores of the ocean everywhere. Of course we find them on practically all of the large fresh water lakes. A few years ago my friend Captain Graham, who has been a salmon fisher most of his life either on Puget Sound or on Columbia River, invited me to go with him to lift his salmon nets. Early the next morning we got into his gasoline launch and started down the sound to the nets. We did not notice an unusual number of gulls on the way and even when we reached the nets and the men began raising them $I$ did not notice more than an occasional specimen flying about. It took something like an hour to raise the nets and get ready to take out the fish. I noticed that as the work progressed gulls in ever-increasing numbers flew about, apparently much interested in what was going on; but not being well acquainted with their habits I did not pay much attention to this, and the fishermen were so used to their presence that they said nothing. When the scow was pulled up along side and the men began taking the fish out of the net, the gulls came from all directions by hundreds. The fisherman's net in modern days is very much like those on the Sea of Galilee of which the Savior said, "The kingdom of heaven is like unto a net that was cast into the sea, and gathered of every kind, 
which when it was full they drew to shore, and sat down, and gathered the good into vessels, but cast the bad away."

These fishermen had a one-pronged fork not so very different from the forks a farmer uses in making hay except in the number of prongs. With this they took the fish from the net, sticking the prong through each fish and lifting it out of the net-the most convenient way to handle them. The good fish are thrown into the scow to go to the canning factory, while those that are not salable are thrown back into the sea. Most of these are fatally injured by the fork, and some thousands of the dying fish were soon floating over the surface of the sound in every direction.

Then the gulls were happy. They came from every direction by scores. A bird would alight on a fish and begin tearing at it with his hook-like bill. If the fish were dead, all well and good; the bird would tear off piece after piece of flesh and eat until the fish became lighter on one side, rolled over, and tumbled the bird into the water. With a scream he would rise into the air and again alight on his fish, but he was always too interested in eating to keep this from happening again. Sometimes, however, a bird alighted on a fish that was not dead, and when he began tearing its flesh of course the poor fish would flop and attempt to swim away. It was amusing to see the surprize and apparent fear of the gull when a fish made a great stroke with its tail and perhaps dodged the gull. With screams of protest he would hover about, pecking and tearing at the fish, but usually ended by trying another victim. It took most of the forenoon to empty the fish nets. Thousands of pounds of good fish were taken out, but I am quite sure there were two pounds of worth- 
less fish in the net for every pound of salable ones. Most of the gulls had not yet gone to their breeding grounds and so there was a royal feast for them all day long. I am sure I never saw so many gulls at one time in my life before or since.

But fishermen are not lifting their nets every day in the year, and it is only for a short season that these birds are enabled to feast on fresh fish as they did that day. Ordinarily they follow ships back and forth watching for the cook to empty the slops from the kitchen into the water or for some interested passenger to throw food to them. They eat almost any sort of food. I have seen them fight as earnestly over potato parings, bread crusts, and other refuse as over fish thrown into the water. When the tide is going out they often gather in large numbers along the shore, feeding on any small creatures that may be left stranded. I have never seen them eat starfish, but they will feed on sea cucumbers and small crabs and shell fish as well as on dead minnows that are washed ashore. Because of these habits of feeding, those who have tried to eat gulls tell me that their flesh is so strong and rank they are not fit for food; so they are never killed for that purpose. As they are enormous eaters and are always ready to pick up anything that is thrown into the sea, they are valuable as scavengers to the people who live along the shore. In fact, anywhere in the United States or Canada it is against the law to kill sea gulls. I have never seen one shot, altho I have frequently seen the stuffed skins. They are powerful in flight, often remaining on the wing for hours at a time; when they tire they settle on the water to rest. They have webbed feet like the rest of the swimmers and are consequently able to swim as well 
as any duck; but their feeding habits are so different that they do not swim nearly as much as do most of the swimming birds.

You will have no difficulty in recognizing sea gulls from ducks and geese, but there are some other birds from which it is not so easy to distinguish them. These are the petrels and the albatrosses. The albatrosses are all larger birds than the gulls. They are usually found along with the gulls and feed in very much the same way, tho they are much more expert in catching food in mid-air. I have stood on deck and thrown food into the air in full sight of an albatross that was at least one hundred-fifty feet away and altho the food had to fall only ten or fifteen feet to the water the albatross usually managed to catch it in the air. The gull is rather more slender and graceful than the albatross, and this coupled with the fact that it is not so large makes it possible to distinguish it while in flight. Most of the petrels on the other hand are smaller than the gulls, have relatively longer and more slender wings, and are more graceful and rapid in flight. They do not come ashore as aften as do the gulls except when nesting, and are usually seen at considerable distance out at sea. From the fact that they are distinctly sea-faring birds they are often called Mother Carey's Chickens. When the weather is so stormy that the gulls are forced ashore, the petrels seem to be in their element. They seem to delight to fly about in wind that is blowing a hurricane and will even dash through the crest of the white caps in search of a bit of food. If it is remembered that they are smaller and that their flight is more rapid and that they dart up and down more than the gulls, one will soon learn to distinguish them from each other. 


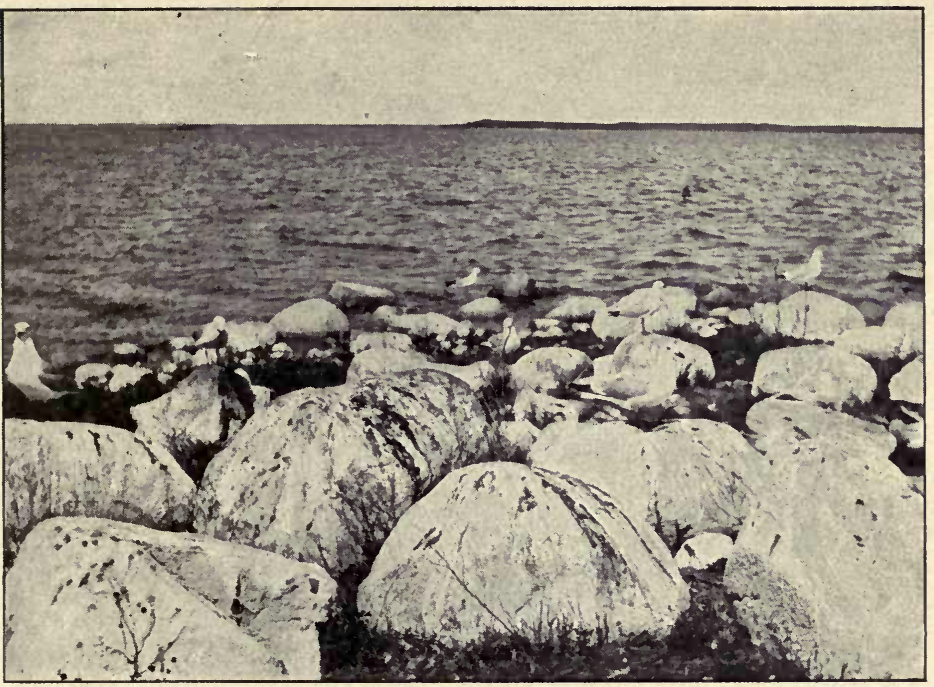

CALIFORNIA GULLS

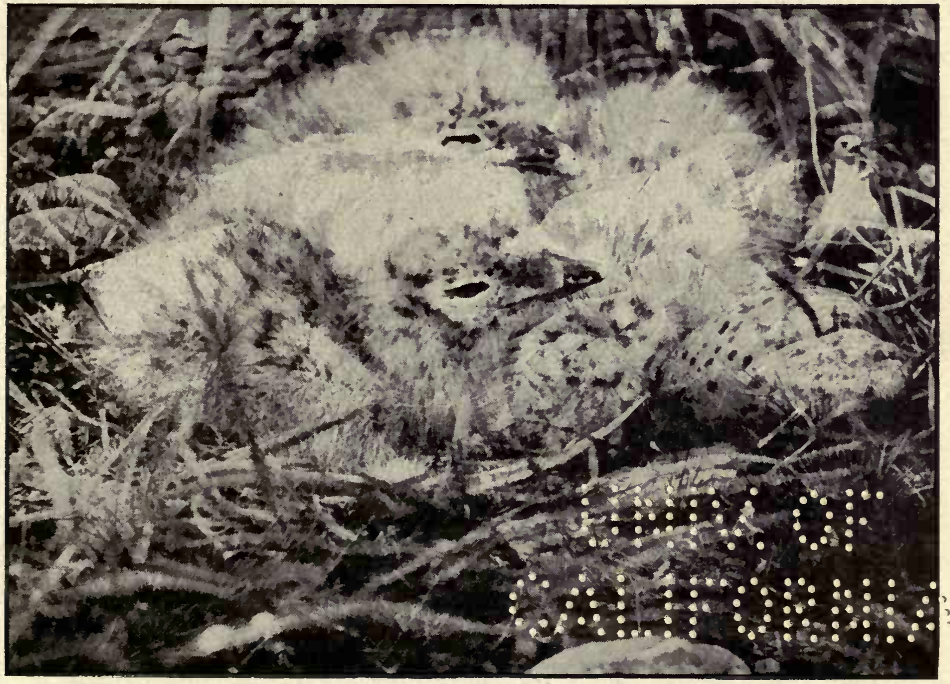



Few of the readers of this book will have the privilege of seeing a sea gull's nest, for, as before stated, they nest for the most part either in the far North or on the coasts, building their nests directly on the ground, often on a small shelf no more than a foot wide with a steep or sheer cliff hundreds of feet above or below or both. Of course during the nesting season they are not common in our waters except where they breed, but they fly all over the United States during the rest of the year. They do not mind the cold of winter, and one sees them following boats back and forth all winter long in New York or Boston harbors. 


\section{${ }_{1} \mathrm{~V}$ \\ THE BLACK TERN}

NE of the most wonderful things about God's creation is the wonderful way each object is fitted to the conditions under which it lives and for gathering the food on which it subsists.

Among the water birds we have already learned that there are two great groups, one of which has long slender legs and as a rule long necks and long bills, just the things that make it possible for them to catch frogs, pollywogs, and other creatures that live along the shores of lakes and rivers where they feed. The other group of water birds has rather short legs with webbed feet, the web acting as an oar making it possible for them to swim very rapidly. Those that feed largely on regetable matter have broad bills which they use as shovels for digging in the bottom of shallow ponds for the tender roots and stems they like so much.

Others, like the gulls that live largely on meat, have more or less of a hook on the end of the rather broad bill to assist them in tearing fish and other flesh-food in pieces. Since it is often necessary for these birds to catch their food among the schools of small fish that swim far out in the sea, they have powerful wings and are therefore able to fly for hours at a time. In some 
ways the terns interest me more than any other water fowl because their provision for swimming seems almost unnecessary. In fact, I have never been quite able to understand why they are water fowl at all. They resemble the gulls in shape and general appearance, but are smaller, some varieties being scarcely as large as a pigeon. All of them have rather long sharp bills, better adapted for feeding on insects than for eating fish or collecting tender roots and stems under the water.

No bird is more gracefully beautiful than a tern. Every curve of its body seems to be especially shaped to give grace and speed in flight, and its wings are strong and so long that they reach well beyond the end of the body. It is no wonder these birds delight in nothing so much as flying. No matter what the weather, they seem always to be in the air, the mother bird scarcely. sparing the time necessary to brood her eggs.

When I was a boy we had very few terns about home. In fact, in Southeastern Iowa it is only occasionally that terns of any kind are seen and those are mostly migrating. However, I used to make occasional trips further north into the northwestern part of the State where I found those birds rather common, especially the black terns whose story I mean now to tell, because undoubtedly it is the most widely distributed of our American terns.

It was not till I went West, however, that I became really well acquainted with even the hlack tern. I shall never forget my first trip through .orthwestern $\mathrm{Ne}$ braska and Eastern Colorado-not the first time I ever rode through on a train, but the first when I had opportunity to drive over some of this country and become acquainted with its birds and flowers. I happened to 
get off at a small station and drive several miles into the country, and to my surprize our road led us past a cluster of small lakes, the largest covering perhaps one hundred acres. These lakes evidently were not deep, for the cat-tails, rushes, and other plants grew in profusion for several rods along the shore. I was surprized to find these beautiful little lakes where I did not know there was any water, and was doubly surprized at the swarm of birds living on their shores. Blackbirds, killdeers, curlews, several kinds of ducks, a few gulls, and black terns were there in such numbers as I have seldom seen anywhere. In fact, I have often said that on the shores of these lakes water fowl were as thick as the chickens in the barnyard at home, and many of them seemed almost as fearless.

It was the last of May or the first of June, I am not sure just which, and knowing that this was the time most of these birds would be nesting I could not forego the pleasure of spending some time looking for nests and young birds. Here was a mallard duck leading half a dozen balls of fluffy down into the tall rushes, and there was a pintail duck, equally bent on hiding her youngsters among the cat-tails on the other side, while nests of the red-winged blackbird were to be seen on every hand. I started to pick my way along the edge of one of these little lakes when suddenly a black tern began to circle over my head and scream in the most excited way. "A-ha," I thought. "You have a nest somewhere near. I wonder if I shall be able to find it." I moved a few feet further and she became more and more excited every moment, circling closer and closer and screaming louder and louder. Somehow I missed her nest and 
when I passed on a few rods she become less excited and less loud in her protests of anger.

When I was a boy we used to play a game called magic music. A boy or girl was sent from the room and the rest of the party agreed on some object which he was to find on his return. When he again entered the room some one began playing a violin, playing slowly and softly when he was no where near the thing agreed upon and faster and louder as he approached the object he was to find. Guided by this music alone he was supposed to discover what the company had decided upon. Now it struck me that this bird and I were playing a game of magic music. At any rate, had it been her greatest anxiety to help me find her nest she could not have done it better. I turned and retraced my steps, when her outcry became more constant and more excited and again she began darting close to my head. When I came within three or four feet of her nest she actually struck my hat. I stopped at once and peering about saw the nest-a pile of rushes and reeds apparently dumped with no particular order in the edge of the shallow water among the rushes. She had not even taken the trouble to wallow a respectable depression in the top of this pile, but had merely laid her three eggs together on the top. I never have been able to understand how she could brood these eggs; first, because there were so many openings in the under side of the nest that I do not see how she could keep them warm, placed as they were only four or five inches above the water; second, I do not see how she could hover and turn them, as every bird must turn her eggs, without their rolling apart if not into the water.

Her eggs must be wonderfully vital and capable of 
hatching at a comparatively low temperature, for not only is she handicapped by not having a warm nest in which to brood them, but she is so fond of playing in the balmy air that she seemingly finds little time to sit. I have never seen a black tern sitting on her nest. Undoubtedly she does so, but when or how I am unable to say. Audubon, that great authority on birds, tells us that both the male and the female sit and undoubtedly he knew what he was talking about, but certainly neither sits long enough to grow tired. We are told that it takes seventeen days to hatch a black tern's egg. When the eggs are hatched the young birds are such a wonderful mixture of brownish black and other neutral colors that it is almost impossible to see them, and, more than that, by the time they are three days old they do not hesitate to slip into the water and swim away and hide under the bank or among the rushes whenever the nest is even slightly disturbed. Their parents feed them mostly on water spiders and other water loving insects, but do not hesitate to add to their bill of fare butterflies, grasshoppers, dragon-flies, and any other insects that may come handy. The parent birds seem to be in the air almost all the time, flitting and circling about hither and thither and back and forth hunting food. As they can catch that swiftest of insects, the dragon-fly, in a fair race, and as they feed on any of the flying insects, doubtless they have little trouble in picking up an abundance of food. However they do not hesitate to feed on grass and on land-living insects when occasion demands.

The black tern raises only one brood each summer, tho if the first nest is broken up it will build another. The young develop their wings quickly and are soon 
able to look after themselves in the matter of flying and catching food. These birds are abundant over the northern part of the United States and the southern part of Canada from Northern Ohio to the Pacific coast. I have seen them in the breeding season in Michigan and northern Indiana, and they occasionally are found as far south as the northern part of Missouri, tho certainly this is rare. With the return of fall they fly to the seashore and unite with the great flocks of gulls and other terns that congregate there for the winter, becoming active fishers. I do not think they do much fishing during the summertime, but in the winter they are often active in picking minnows out of the water even at a considerable distance from the shore. In Florida and the other gulf districts, however, they undoubtedly catch a great many insects even in winter.

Terns in general and the black tern in particular are birds evidently intended by the great Creator for our pleasure. They do no harm in any way, living as they do along creeks, ponds, and lakes. Doubtless the insects on which they largely feed are not the ones that would do our crops much injury, so we would not class them among our most beneficial birds; but it seems to me that it is nothing short of barbarous to sacrifice the lives of millions of terns, as has been done in the past, merely to ornament women's hats. Fortunately the law now gives them protection, and it is to be hoped that before many years we shall again see them in the great numbers in which they existed thirty or forty years ago about the streams and ponds of the Dakotas, Minnesota, Colorado, and adjoining districts. 


\section{KNOWING BIRDS THROUGH STORIES}

\section{Key to the Families of Longipennes}

RYNCHOPIDE-Skimmers.

With the lower mandible much longer than the upper.

LARIDX-Gulls and Terns.

With the lower mandible not longer than the upper, and with the upper mandible in one piece.

Stercorarimde-Jaegers.

With the upper mandible composed of three pieces, one a saddle-like basal portion.

\section{Key to the Families of Tubinares}

DIOMEDEIDE-Albatrosses.

With the nasal tubes separated and situated on sides of the upper mandible.

Procrllarifdx-Petrels and Shearwaters.

With the nasal tubes united and situated on the top of the basal portion of the upper mandible. 


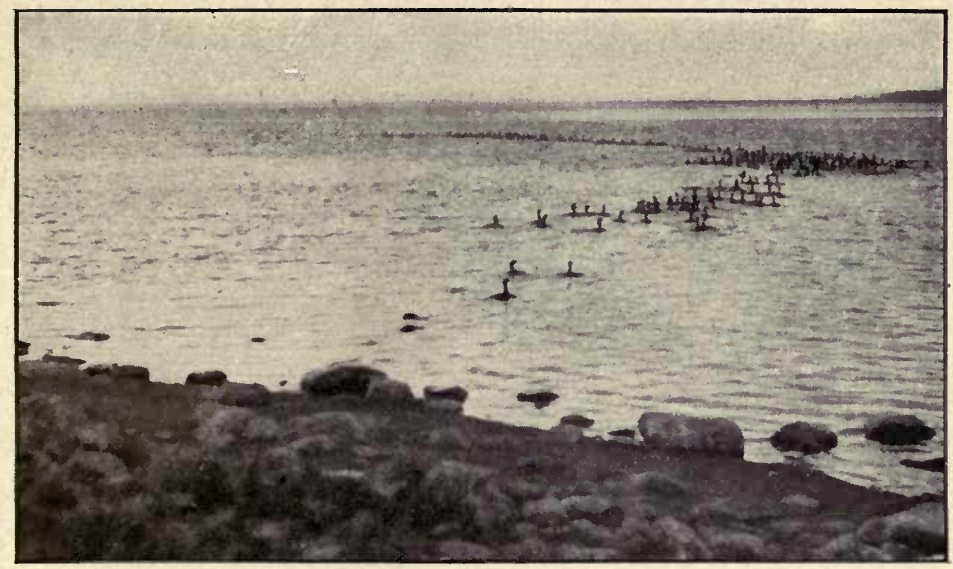

YOUNG DOUBLE-CRESTED CORMORANTS

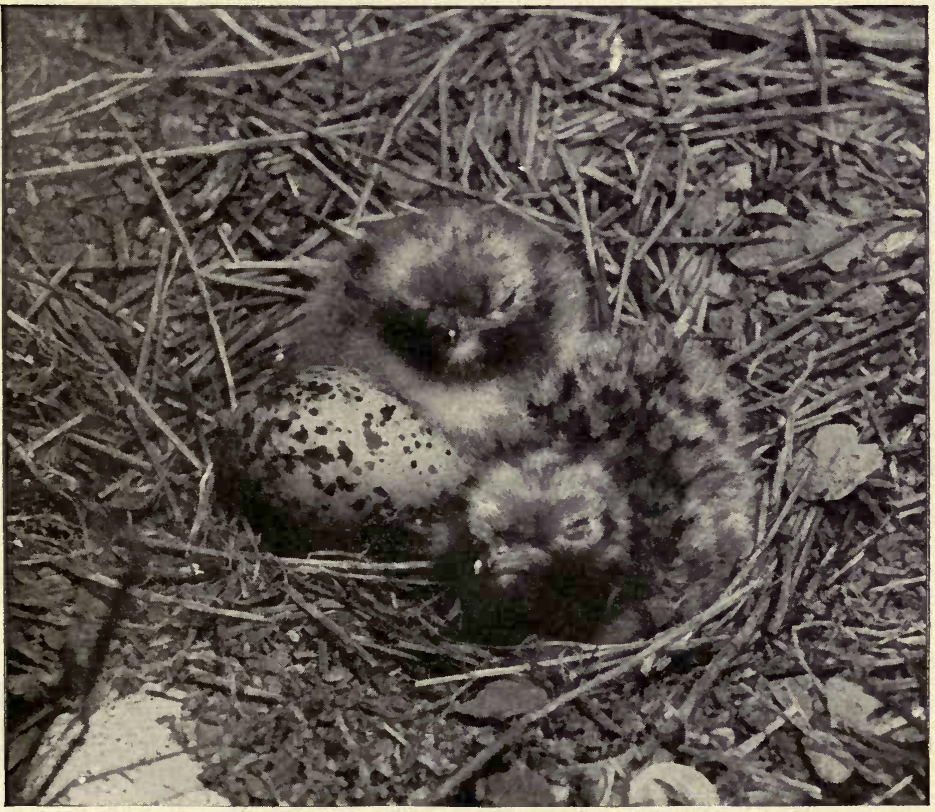

YOUNG TERNS

(See Chapter 5) 


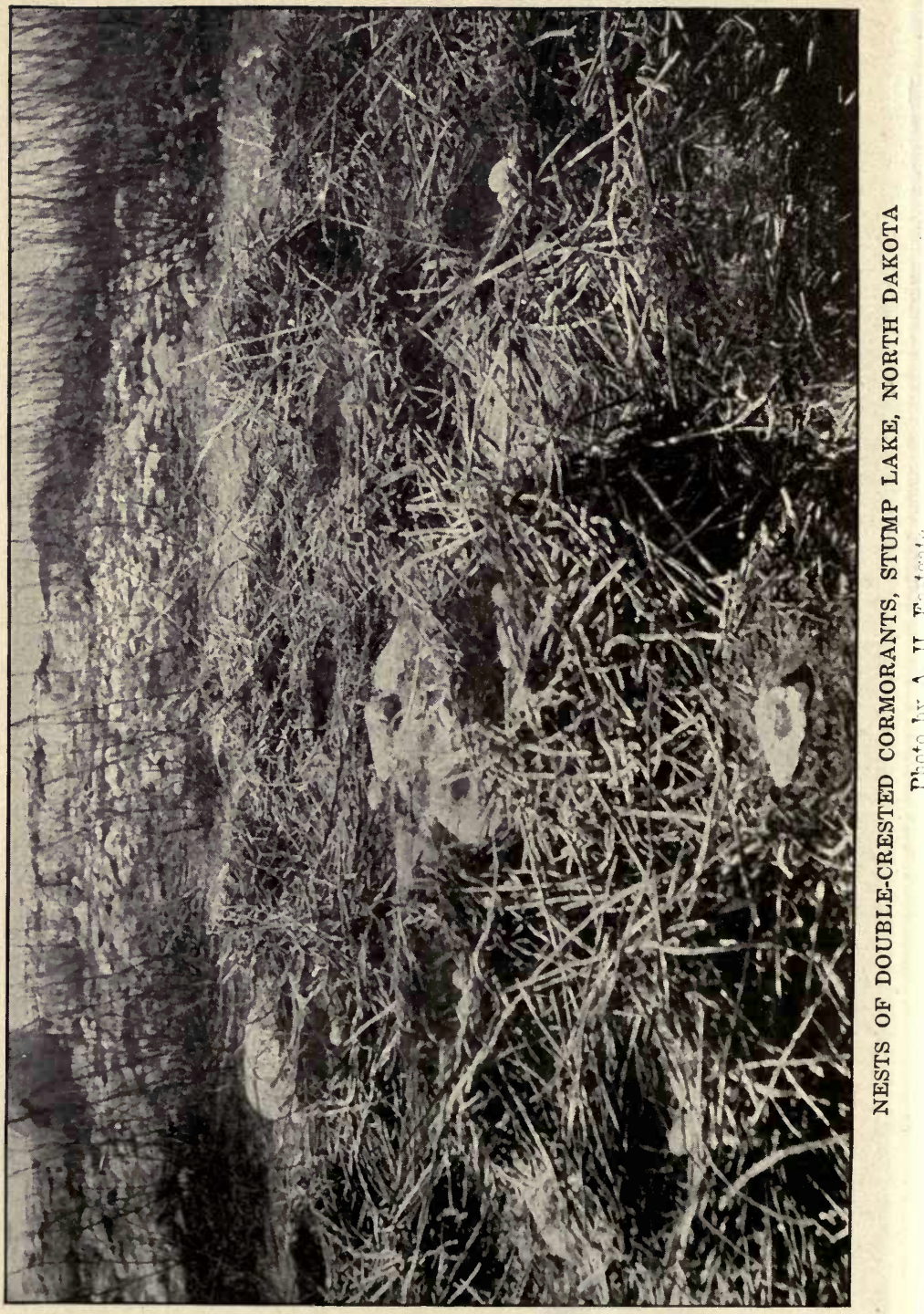




\section{VI}

\section{THE DOUBLE-CRESTED CORMORANT}

COME birds, like some people, do not always follow the $D$ good and wise habits of their forefathers. The cormorants evidently belong to this class. Having feet similar to a goose's and a body that closely resembles that of a duck, they have lost the custom of eating roots, grass, grain, and the tender shoots of plants and turned to be meat-eaters. The bill, altho not broad at the base like the duck's, is stout throughout its whole length and is hooked like that of a bird of prey. Cormorants differ from loons and many other diving birds in that they retain strong powers of flight and are able to rise out of the water almost as easily as a goose or a duck.

Doubtless because they find a better supply of food there, they are confined largely to the coast and are therefore not found inland except on suitable bodies of water. They live during the summer time mostly on the islands off the coast of Labrador and Newfoundland, where they congregate in great numbers. They are especially numerous in those parts of the country that are so sterile and forbidding that no man lives there and only occasional fishermen come. They nest preferably on high rocky cliffs, but they also build nests by the thousands along the shore out of reach of tidewater. Other forms of this 
species breed on the Pacific coast and on the large lakes of the Far West.

The old birds gather dead weeds, a few sticks, moss and seaweed by the bushel and often build their nest as much as two feet high. The nests are built about as close together as they can be placed, these birds seemingly feeling more secure when close together.

Audubon, who visited the nesting grounds, tells us that when his boat landed, the parent birds all rose together and flew out to sea, alighting well out of range of their guns, where they remained until his party had finished their explorations and left the nests. He says he found young birds of all sizes as well as eggs, which makes it plain that these birds do not all nest at the same time. When they drew near to the nests the young birds which were old enough to do so promptly scrambled out of the nest and huddled together in little groups of fifteen or twenty, while others hid themselves in the crevices and crannies in the rock. They tried their best to flatten themselves out against the rocks and earth so that they would be as inconspicuous as possible and then crept along very much as I used to do when I was trying to creep up on game. Not being possessed of both hands and feet as I am, they did their best by using their wings, their feet, and even their bills in pulling themselves along over the surface.

If any one approaches closely they begin to make their necks writhe very much like the writhing of a snake. As Audubon says, this motion has such a snakelike appearance that it is positively revolting, nor does the resemblance end here. No sooner does the intruder get close than the birds begin hissing loudly and continuously. They doubtless feel that they will be able to frighten away their 
enemies, and probably they are sometimes able to do this. Not so with the fishermen, however. That fishermen are used to a rough, sea-faring life, and as they must make their living from the fish they catch they are always anxious to secure an abundance of good bait. They made it a practise to land on the cormorant's nesting grounds and kill the young birds by the hundreds or even thousands, using them for bait in their sea-fishing. It seems strange, but fish, when they are looking for a delicate tit-bit, often prefer the creatures that live on land to those that live in the water, just as most carnivorous animals and birds often prefer fish to other animals.

These birds ordinarily lay two to four eggs, which, if they were thoroughly cleaned, would be of a greenish color like a duck's egg. As it is they are usually covered with a whitish deposit and are often so plastered with mud and filth that it is difficult to tell the real color. When the young birds hatch they are queer, ugly little creatures, covered with a muddy black down. They are helpless, being blind for more than a week. For perhaps two weeks the mother birds feed them by emptying their own stomach into the throat of the young bird. When the bird is old enough to see well and is beginning to be quite well feathered, say by the time he is two weeks old, he should weigh about two pounds.

Now the mother begins to place whole fish in his mouth and allows him to tear them up for himself. In a few days she will cease taking even this much trouble, but will lay the fish on the side of the nest or on the ground by the nest and expect the young bird to get them when he is hungry. The young grow very rapidly, but they stay in the nest, or at least do not leave it for more than a short 
time, until they are able to fly, or at least swim well. As soon as they can fly, they are deserted by their parents, who seem to feel that now they should be able to look after themselves.

The favorite food of the cormorant is fish and other small aquatic animals near the shore, and they eat also thousands of young cod and other fish. Feeding as they do, their flesh is never used for food. In fact, even their eggs are so strongly flavored that the fisherfolk who collect the eggs of gulls and other water birds for food never think of eating the cormorant's eggs.

In the late fall the birds migrate to the coast of northeastern United States. In flight, one not used to them might mistake them for large ducks as they usually fly in a straight line as the ducks fly. Sometimes, however, they form a $\mathrm{V}$ shaped line like wild geese.

This cormorant is dull grayish-brown on back and wings, black with a faint greenish sheen elsewhere. On his head in the breeding season are two plume-like tufts of feathers which curl forward, making a conspicuous double crest, which gives the bird its name, the double-crested cormorant. We have several varieties of cormorants, but the double-crested one and its sub-species is the one most generally seen in our country but is not the most beautiful. As his habits are very similar to those of the other members of the family, it is not necessary to tell the story of the others. 


\section{VII}

\section{THE WHITE FISHER'}

W ${ }^{\mathrm{HEN}}$ I was a small boy I was sometimes allowed to accompany my older brother on a duck hunting expedition to Skunk River, two or three miles away. We usually got away from home before daylight and walked with the expectation of reaching the ponds by sunrise, for that is the time at which there is the best chance of getting wild ducks. One spring we had not been able to get away from home and go hunting as often as we wished, which would have been a great many times indeed. I am ashamed now that I ever went hunting at all in the spring, for at this time birds are so intent on love making and nest building that they do not have a fair chance; and besides a bird killed at this time means several more that they might have reared that season.

Along about the last of April, after most of the ducks and geese had gone north, some one told us that there was a flock of ducks staying in the crabapple pond. That was very interesting news, for hunters had long since gone to the more profitable business of plowing for corn, and so we boys were sure that our chance of securing some of these ducks would be very good. As there were not so many hunters along the river, we thought it would not be necessary to go early in the morning; so after break- 
fast we did up the chores about the place, got on old Phoebe, Brother John riding in front and carrying the gun, and I behind, and started for the river. It was an uncommon thing indeed for us to be allowed to go duck hunting on horseback, but we had promised that if we might take a horse we would get back for dinner and that brother woald plow in the afternoon.

We reached the vicinity of Sellar's pond about nine o'clock in the morning, tied old Phoebe to a tree, slipped into the field, and began creeping on hands and knees toward the pond. There was a high hill rising abruptly above Sellar's pond on the side away from the river, and we were on the brow of this hill. This gave us some advantage, for a bird sitting on the water a hundred feet below is not so apt to notice objects on the top of the hill as those that are somewhere near the level of the water. There was a small clump of buck brush just on the brow of this hill, and we crept up behind this. When we were able to see the water below, we both gasped with pleasure and excitement, for on the far side of the pond were fire giant white birds as big as small sheep. To our excited eyes they looked as large as cows.

Neither of us had ever seen any birds like these at anything like close range before. They were snow white, all but the quill feathers of the wings, which were black, making a black bar across the side of the body. The body was large and plump and the neck comparatively short. I say comparatively, because it was not nearly so long as the neck of a swan, the only water bird anywhere near their size; but the thing about these birds that attracted our attention most was their enormous bills. These bills were nearly a foot long, and had a tremendous pouch under the 
lower mandible that looked as though it might hold a gallon of water. We were close enough to see them very clearly. I whispered, "What are they?" and John answered, "Pelicans." We had a few times seen great white birds fly silently over head, flapping very slowly yet showing great strength and power of flight, and had been told that they were pelicans. In fact, father and mother had told us that in the early days, when they first settled in Iowa, pelicans were common along the river; but that was in the days gone by, and only on rare occasions had any one in years seen one in those parts, much less known them to alight. True, only the year before we had been surprized to see a flock of more than a hundred fly over, and father had taken this occasion to tell us wonderful stories of the days when pelicans used to nest on Holmes Lake and keep the ducks and geese and eren the swans away from their neighborhood.

We watched these birds for several minutes, forgetting all about the wonderful opportunity of shooting them. They evidently were hungry, and had alighted in this pond because it was well stocked with minnows. At the lower end there was a sort of slough through which at high water the river ran across the field to the Crabapple pond a few hundred yards below. This shallow neck narrowed down almost to a point. Evidently those pelicans had not been long on this pond, or else they had roosted there and, having fed to the full the evening before, were just getting ready for breakfast. At any rate, though they had been quietly floating on the water when we first saw them, an old pelican suddenly raised his head, flapped his wings and started swimming across the pond toward this shallow neck. The other pelicans very quickly fell in line, swimming 
three or four feet apart, moving very much as a company of soldiers would move in making a charge. When they came to where the water was shallow they evidently began to see fish, or now they quickened their pace, and began beating the water with their great wings, making it splash in every direction as all bore down toward this shallow point. We watched in breathless interest until they drove down to where the water was scarcely deep enough to swim in, when suddenly they ceased their rapid advance and begun scooping their great bills down into the water. A pelican would use his bill as I would use a small net when catching minnows. Making a rapid scoop through the water, then closing the bill just tightly enough that no fish could escape, would raise his head and allow the water to run out. Then he would swallow the fish he had caught and make another scoop.

They worked very rapidly for ten or fifteen minutes, moving forward to the very point of the little neck of water. Of course I never know how many fish they caught, but I know the trick they had practised very well, for we small boys had learned that when we wished to catch fish in a minnow seine, if we formed in line across a stream and move forward, splashing the water and making a commotion, the frightened fish would run ahead, and when the proper time came we could use our coffee sack seine and catch dozens of minnows. It seemed wonderful to us that these birds should have learned this trick and were wise enough to work in concert.

By the time the birds had chased the minnows down into the lower end of the pond and our curiosity had been satisfied by watching them fish, they were out of range of our old army musket, which had been reamed out to make 
a shot gun. We were not wise enough to lie still and wait until they came back into range, but brother told me to lie still and watch and he would creep down the brow of the hill till he got within gunshot. He started on this expedition, but had gone only two or three rods when the pelicans, having finished their fishing, turned about and started to swim back up the pond. One of them spied his head and the end of his gun above the skyline and gave utterance to a low noise very much like that you make by blowing into a large bottle, and without more ado they all took flight. We watched them go down the river and disappear behind the crabapple grove on the bank of Crabapple Pond. Supposing they had alighted in this pond and resumed their fishing, we followed.

We spent most of the forenoon following these birds from pond to pond and it seemed to me that we must have crawled miles on our bellies in the vain attempt to get within gunshot again. They apparently were not wild, for they never flew far at a time, merely going from pond to pond, but for some reason or other they were on the alert and saw to it that we never again got within gunshot. Once or twice during the morning a flock of wild ducks flew overhead within range; but we were stalking pelicans, and the desire to kill one of them was so strong that we would not shoot at smaller game lest the noise of the gun frighten away the larger birds that we hoped to get a little later.

When noon came and we had to go home, the only thing we had to take with us was a wonderfully interesting story -which is, after all, the most valuable thing a hunter can get. The next day father determined to go to the river and get one of these pelicans. He had long since 
giren up duck hunting, but pelicans were different. Accordingly he shouldered his gun and tramped to the river before daylight. Along about one o'clock in the afternoon he came home carrying five or six wild ducks but reported that he had not seen any trace of the larger birds.

Evidently they had gone north during the night.

These were the last of their kind I ever saw until I went to Utah some ten or fifteen years later, in the year 1898. I spent two years at Provo City, which is situated near the beautiful fresh water Utah Lake. This lake is some twelve or fifteen miles wide, and has a small rocky island near the middle. The island is neither more nor less than a low mountain rising from the bosom of the lake. A number of pelicans nested regularly on this island. It is in such places that they always prefer to live. They either nest on some high rocky point or select a low or high rocky island at some considerable distance from the shore, usually choosing an island that has no human inhabitants. There they build their nests by merely making a shallow depression in the ground or by making a heap of earth and lining it with grass and feathers or sometimes with sticks and rubbish. Their eggs are very large, among the largest of the eggs of birds which live in America.

I used to like to go down to the shore of Utah Lake of an evening and watch the pelicans. They seldom fish in flocks during the mating season. In fact, while others claim that they usually fish in flocks, I never had the good fortune of seeing them do so except as I have described above. Utah Lake was so full of minnows and fish of all kinds that perhaps it was unnecessary to fish in bands. At any rate the usual procedure was for an old pelican to come flapping across the lake, flying very low 
so that he might easily observe any fish in the water below. At the upper end there were a number of small streams that flowed into the lake close to each other. At the point where these streams entered, the water was shallow for a considerable distance, and was grown up with rushes and cat-tails. No one could wade here and it was too shallow to go with a boat. Among these reeds thousands of small fish played during the hot summer days, for not only was there food abundant but they were safe from larger fish. The pelicans always headed for this part of the lake. Here a single bird could drive the minnows into a nook and quickly catch them. When the old bird had eaten all he wished, he would fill his pouch to the brim and lazily fly over to the island to feed his young.

I have never had the opportunity of seeing one of these birds feed its young, so I do not know how it is done; but I do know that one day a pelican flew reasonably near and a friend of mine who was with me in a boat shot at him. Of course he did not hurt the pelican, but it was frightened so badly that it dropped two or three fish out of its pouch. We rowed quickly to where those fish fell to see if they were dead or alive. We knew that if they were injured they would be found floating on the surface of the water, but as we could find nothing of them we were convinced that they were uninjured.

The white pelican is no longer found over the greater part of the United States, except during migration, altho in the early history of this country it was found much more extensively. It is recognized by its giant bill with a large pouch beneath. Several varieties are often seen in our city parks, but our American species differs from all of the others in that it has a bony protuberance 
on the top of the bill during the breeding season. The pelican is one of the largest of North American birds. He is still found in numbers in the Yellowstone National Park, where he nests on the islands in the Yellowstone Lake, and at isolated localities in the Western United States.

\section{Key to the Families of Steganopodes}

Phaethontide-Tropic-birds.

With the head wholly feathered and the nostrils easily seen.

ANHINGIDE-Anhingas.

With the head not wholly feathered, the nostrils not easily seen, the bill slender and sharply pointed, the tail and its feathers rounded.

SulIDE-Gannets and Boobies.

With the bill stout but not hooked, the tail more or less wedgeshaped and its feathers more or less pointed.

Fregatide-Man-o'. War Birds.

With bill distinctly hooked, tail forked, and space around eye feathered.

Pelecantde-Pelicans.

With bill having a large pouch beneath, extending to the tip of the lower mandible.

Phalacrocoracide-Cormorants.

With bill narrow and distinctly hooked, a small throat pouch not extending to the middle of lower mandible and the tail not forked.

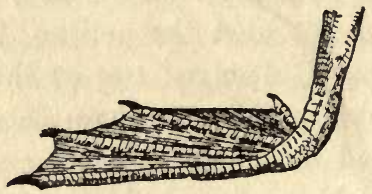

Fully Webbed Foot of one of the Stranopodes 


\section{VIII}

\section{JOHNNIE GREENHEAD}

THE boy had been wandering up and down Skunk River 1 all one Sabbath morning in the hope that he might be able to surprize a "thunderpump" (or bittern, as I would probably now call it), and so be able to learn just how he makes his thundering noise. The old hunters of the neighborhood differed so widely in their opinions on this point that the boy had made up his mind that there was only one way to decide the matter-to see for himself. The morning was bright and the sun was doing its best to warm everything into activity. Squirrels scolded in the trees,flowers bloomed on the ground, and birds were singing everywhere. In fact, it was just the kind of day that calls man to worship in "God's first tabernacles," the woods. There being no convenient church privileges, the boy's parents believed that no boy ever receives any impression other than those of reverence and good when alone with nature, and so did not hesitate to let him go to the woods at any time.

Suddenly, not far from the old willow mill, the noise of a "thunderpump" was heard. The boy knew this bird must be on the shore of the river just around the bend and determined to creep up, making no noise, and catch it unawares. Slipping through the underbrush as quietly 
as possible, he poked his head over the edge of the bank to see this "thunderpump" disappearing around the bend of the river above. Disappointed and tired from his long crawl, the boy dropped on the sod and began looking about with no purpose in particular. Finally his eye rested on a hollow snag, perhaps a hundred yards away, just in time to see a wood duck enter the hollow. The boy had never been told that the wood duck differs from most ducks in that at times it not only lights in trees, but actually nests in hollow trees, so of course he was interested.

While he was watching this hole and wondering whether it were possible to catch the duck while she was inside, as he had sometimes been able to catch mother screech owl or father redhead, the woodpecker, the duck flew out of the hole with something in her mouth. This was still more amazing to the boy. He had seen crows carry eggs in their bill, but a duck-who ever heard of such a thing as a duck carrying anything in its bill? And granting that ducks do carry things in their bills, what could this duck have found in a hollow tree? Surely ducks do not rob birds' nests.

But he did not have to speculate long, for this mother of the forest, unaware of his presence, flew toward the high bank on which the boy was resting, where the river made $a$ bend and the water was perfectly quiet-at least no current was noticeable. As she came near, the boy was astounded to see that she was carrying a baby duckling in her mouth. Flying to within some ten feet of the water, she dropped her burden and started back to the tree. The baby duckling dropped into the water without injury and began paddling round and round not more than fifty feet from where the boy lay. In a few moments, the mother 
returned with another duckling which she dropped in the same way. Now the two ducklings swam round and round together while the mother went back for a third. This was kept up until fourteen baby ducklings had been dropped into the water, when the mother herself alighted and led them across the river to where the water was shallow and the reeds were plentiful, where they began to feed.

This certainly was to be a red letter day for the boy. He not only had learned that the wood duck nests in trees, but had been so fortunate as actually to witness her carrying her brood to the water, now that they were old enough to require food and not to be injured by swimming in the water.

Some Sabbath days, if the weather was fair, the boy stayed in the woods most of the day, and he decided that this was going to be one of those days. After spending two or three hours watching this mother wood duck feed her babies, he followed the river up to the mouth of Wymore's branch and decided to follow this creek home. Not far from where this creek runs into the river in those days there was a small marsh, no more than a rod or two square, in which bulrushes and sweet flags grew. The boy was fond of chewing sweet flag root, calamus he called it, and he decided to get a piece of this root. Carefully picking his way from tussock to tussock in order to reach the finest calamus bed, he was startled by seeing a mother mallard duck fly out of a clump of rushes. He had been told that wood ducks occasionally still nested along the Skunk River, but to find a mallard's nest was a surprize indeed. In this nest were a dozen green eggs a little larger than a hen's egg. The boy put them into his hat, that con- 
venient receptacle in which he carried everything that he found in the woods from strawberries to mud turtles, and trudged home with his treasures, determined to set them under his old duck-legged hen, that wonderful motherchicken of his which had grown so old that she seldom laid more than a few eggs in a clutch, and could always be pursuaded to sit by merely placing her in a barrel with a nest full of eggs and covering her up for a day or two. This hen had not only incubated but cared for birds and fowls of every description for the boy, from barred owls and red-tailed hawks to quails, guineas and peacocks. It would not be a hard matter to induce her to become foster mother to a flock of mallard ducks. In fact, it was doubtful whether this mother hen would ever know that her wards differed from the domestic ducks that she was accustomed to care for every summer.

On reaching home, the eggs were put in a large dish in the cupboard with the expectation they would be set in the morning. The family cooking was done in a wood stove that stood not more than three or four feet from this cupboard, and of course the air in the cupboard was warm as a result of getting the evening meal. When the doors were closed for the night, this air would remain warm until morning.

Next morning, when breakfast was about ready, the good mother as usual called the boy to help by setting the table. Opening the cupboard to get the dishes, what was his surprize to find not his duck eggs, but twelve fluffy, little ducklings. All had hatched over night. No matter, mother hen could be induced to take care of almost any kind of orphan, whether she were sitting or not; so she was placed in a coop with these ducklings and given a dish of water 


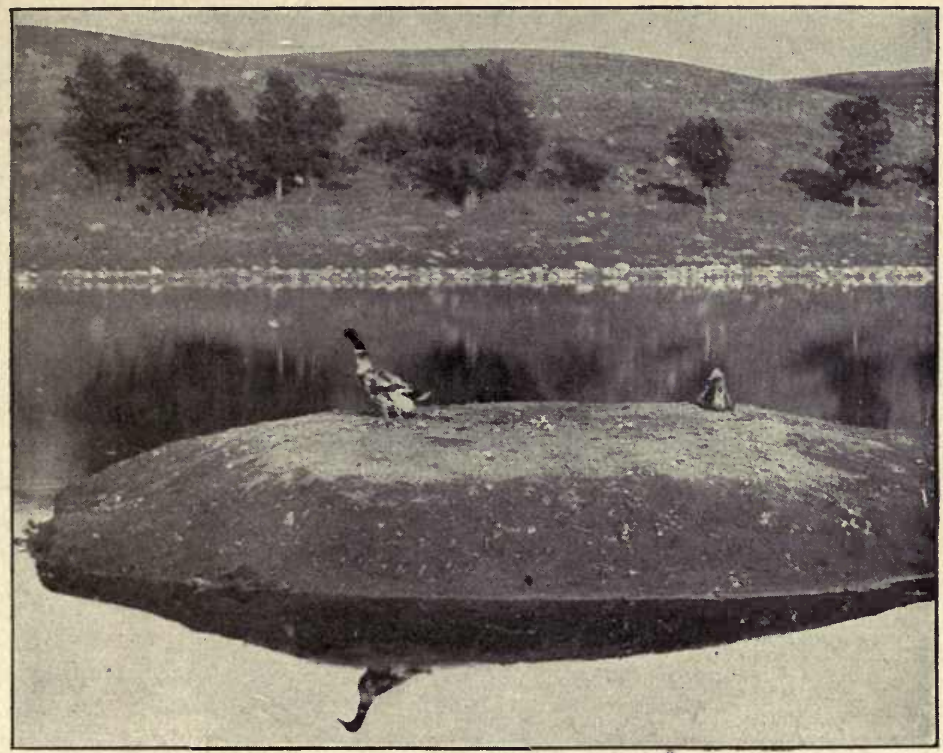

MALE AND FEMALE MALLARD

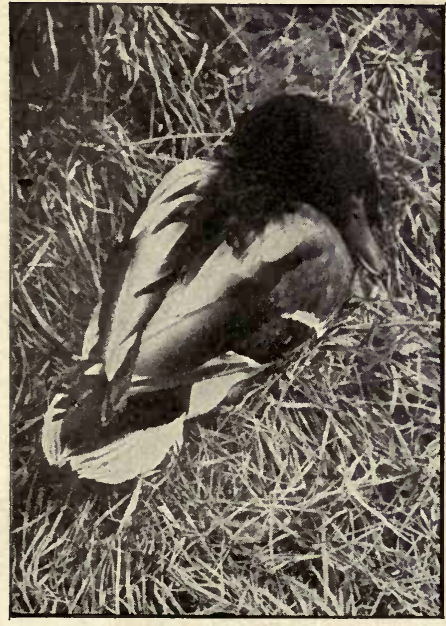

MALLARD DRAKE

Photo by Frank C. Pellett

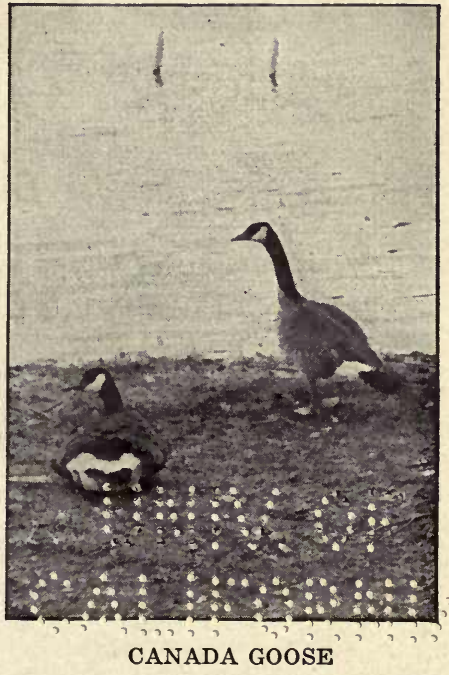

(See Chapter 9) 

and some corn meal mixed with sand and enough water to form a stiff crumbly dough.

Those babies of the wood were exceedingly shy. In fact, there is nothing more surprizing than to see how different are the actions of newly hatched domestic fowls from those of wild birds of the same kind. Whereas newly hatched domestic ducklings would have been content with this chicken mother and would have remained with her as readily as with their own mother, this was not true with these baby mallards. It was only with difficulty they were persuaded to accept her care. In time they became tame enough to allow themselves to be fed by the members of the family, but they were always shy when strangers came about and were continually running away from their foster mother. When they grew older, one after another disappeared. Whether they died or ran away or were stolen, the boy was never quite sure, but when fall came, only Johnnie Greenhead remained. His companions gone, he gradually accepted the company of the domestic ducks; and as they were greenhead ducks themselves, probably descendants of mallard ancestors of less than a hundred years before, he came in time to feel quite at home with them. Having been fed the best of everything from babyhood, he grew to be a giant of his race. Not only was he larger than a wild mallard, but larger than the largest of the domestic drakes in the farmyard.

The boy's mother was a provident soul and believed that ducks and geese should be picked several times a year, for were not feathers necessary if one desired a warm, comfortable bed or good soft pillows? When picking time came, all of the victims resented the operation more or less, but to Johnnie Greenhead it was a tragedy, the more so 
perhaps because he not only had his body feathers plucked, but the quills were pulled out of one of his wings. This latter was to prevent his being able to disappear as had his fellows. Picking ceased, however, about the first of October, for fowls must have an abundance of warm feathers during the cold Iowa winters.

When the wild ducks came trooping southward from the nesting grounds of northern Iowa and Minnesota, Johnnie often flopped his wings and tried in vain to join them; but it was of no avail, for no bird can fly with one full wing and the other plucked.

By the time he had grown wing feathers the ducks had long since ceased passing over, so he settled down with more or less content for the winter. By spring every one took it for granted that Johnnie was fully domesticated, and he seemed to share the general opinion. At least he seemed contented to stay with the flock that spring and summer, and for that matter the next fall and winter. No one thought of keeping his wings plucked any more. But Johnnie brooded over his troubles every time he was picked, and finally he began to lead the flock to the brook that ran past the wild grape arbor and the crabapple thicket. No one thought much of this, for it was the custom of the farmstead to pen the ducks every night during laying season and not to give them their liberty until eight- or nineo'clock the next morning, by which time all the eggs were laid. The rest of the day they were allowed to run at will, for the mistress believed that ducks always do better if they are allowed to swim and feed in the water at least a part of the day, especially during the breeding season. Johnnie became still more resentful when one day, as a result of his leading the flock to Wymore's Branch, a 
half mile away, they were shut in the horse lot and were not allowed to go to the brook to swim. Evidently the love of freedom was fast coming to outweigh the feeling of security and the love of plenty of good feed at home, or was it that Johnnie had no idea of the hardships of the wildlings? However this may be, late in April he decided to leave his friends and the only home he had ever known.

One bright morning, just at daybreak, he rose into the air and flew straight toward the river some two miles away.

It was fortunate for Johnnie that the weather had come off warm and fair and every one was busy sowing oats or plowing corn. Had he decided to leave ten days earlier, when there were hunters stalking every pond and every bend of the river, his fate would have been certain, for his training had taught him that the instinct to fear man was only a delusion.

With a glad quack he lighted in the crabapple pond and began swimming around and feeding on the luscious water grass that lined the shore. If only the rest of the flock had come with him he would have been perfectly happy, but he was not so sure about being alone. But as he was growing lonesome and was hesitating in his mind whether he ought to return to the farmstead or remain where he was, a lone duck, one of his own race which had her wing injured by a stray shot and so was left behind by the flock but had sufficiently recovered to be able to fly again, chanced to light in this pond, and this settled the matter. Both were overjoyed at the meeting. For two or three days they remained in the vicinity, every day Johnnie Greenhead learning more wisdom from his new found friend. Finally, both growing more strong of wing and sure of themselves, Johnnie permitted himself to be led, as 
every wild husband does, by his bride, in search of a nesting place. Out into the open blue they flew, mounting higher and higher until they were well above the range of the best guns, and then through the biting cold air on their journey northward. With a speed that would carry them many a mile every hour, it did not require long to bring them to the lakes and marshes, where his wife informed him they were to stay for the summer. Already they were two weeks behind time, so without many preliminaries they established a home on a point that projected into a shallow marsh lake. The female wallowed a hole in the ground among the tops of a fallen tree, carefully lined it with grass and with down plucked from her own breast, and soon a new pearl was being added every day to the treasure trove it contained.

Others of their race were nesting at different points around this lake, and it was from these companions that Johnnie learned much of his wisdom. In the farmyard he had learned to fear nothing except being caught on picking day. Even there he had learned that if he could escape from the flock and manage to hide under the straw in the old straw pile or to creep into the dried leaves caught by an old brush pile whenever any one attempted to drive the flock into the barn, he could escape; and when the picking was over he might return to the flock in safety, for the mistress would not go to the trouble to catch and pick only one duck.

He had learned that when a dog comes about, one is pretty sure to be safe if he pays no attention to it, for then the dog takes it for granted that he belongs where he is; but he had had no experience with wolves, the wild dogs of the forests. One day a wolf wandered by where Johnnie 
was feeding and when his mate hastily swam into the deep water, Johnnie totally ignored his presence as he had learned to do to a dog in the farmyard. He did not realize his mistake until the wolf sprung for him, but luck was with him. The creature fell just short of the mark and Johnnie escaped with the loss of only a handful of feathers. All of his hatred of being picked now centered around the sight and smell of a wolf. Never again would he sit still and allow such a creature to approach.

When there were ten eggs in the nest, Mrs. Johnnie began to sit. Now Johnnie was disconsolate. In the farmyard the ducks never hatched their own eggs and to be left alone was a new experience. For two or three days he stood about the nest or paddled about in the water near by. His mate, after carefully covering her eggs with down and grass, left the nest for a few moments every day to feed, but then she was too preoccupied to be a good companion. When one fortunate morning he learned that there was a drake's club organized by the heads of the mallard families in the neighborhood who found themselves in the same fix he was, he joined at once. He quickly fell into their way of making this one long gala day, visiting every nook on the lake and feeding to the full. From them he learned to dive to escape from hawks and to dash into the first brush possible when pursued in the air. $\mathrm{He}$ saw a companion which could find no cover when pursued, overtaken by a hawk that tore his throat open and carried him away lifeless. His wife, however, did not feel slighted by his absence, for she felt much safer alone while sitting, for then she could crouch in the grass which exactly matched her color and not be seen. Anyway, he soon lost so many feathers that he could not fly for two weeks or 
more, so he would have been only a source of worry had he stayed about home. His wife, because of sitting, escaped this midsummer molt.

But when, in twenty eight days, his wife led ten ducklings to the water's edge, Johnnie's cup of happiness was full to the brim. Perhaps because of his training on the farm, he joined her at once and together they swam away through the reeds and rushes bent on finding the best feeding grounds for the youngsters. An old hawk that was nesting in a great tree at the upper end of the lake had been watching for some days for just such an event, and her keen eye caught sight of the procession as it swam down the lake. With a cry of exultation she flew toward them, feeling confident she was soon to dine on warm duck. The mother duck had been trained from babyhood to be on the lookout for danger on every hand and she saw the danger approaching first and with a sharp "quack, quack" of warning to the little ones, who led by that strange instinct that tells the wildling what to do as soon as he is out of the egg, scurried away to hide under the bushes. Not knowing what else to do, Johnnie followed and from his hiding place saw the great hawk swoop down to catch his beloved mate. She was on the alert and just as the hawk was within an ace of striking her, she struck the water with her wings and threw up a shower of water, deluging him and disappeared beneath the water to come up a hundred feet away ready to renew the struggle when the hawk struck again. After this was repeated three or four times and the wild mother felt sure the bewildered hawk had lost all thought of the family, she dived and came up in a clump of cat-tails out of sight of the hawk. The baffled hawk flew back to his lookout at the upper end of the lake and 
the mother duck rejoined the family. Then keeping under the shadow of the bank, she swam around the bend out of sight and quietly resumed feeding.

But hawks were not the only enemies against whom these mallards had to contend. One day the mother duck swam out into the deep water and part of the babies followed her. Suddenly there was a lurch and a splash and one of the ducklings disappeared down the throat of a mighty pickerel who had been sleeping in the deep below. She got her family into the shallows among the reeds and rushes as quickly as possible. Not for three weeks did she again dare to cross this deep, and by that time the ducklings were too large for a fish to eat.

Those weeks while the ducklings were small enough to be eaten by large fish were full of anxiety to the mallard family. So long as they remained concealed in the rushes they were safe from hawks; but several times a wandering coyote came near, and the sure danger that could be seen caused them to forget the danger that was not seen and the flock scurried into the middle of the lake. This was precisely what the old hawk was looking for; and twice she carried away one of the ducklings, and a fish accounted for another.

The nights were even more to be dreaded. It was unsafe for the flock to roost in the middle of the lake, for the large fish are much more active at night than by day. On the other hand several coons and mink hunted the shores of the lake every night, and every one of these animals liked nothing better than duck, young or old, and would not hesitate to swim half way across the lake if need be to secure it. Had it not been that there were a dozen other families of ducks on the shore of the same lake, and had 
there not been an abundance of fish for the mink, of crawfish for the coons, and of frogs for both, no doubt there would have been none of Johnnie's children left by the time they were a month old. As it was a mink got two and a coon one before they were large enough to roost with safety in the middle of the lake, and it was a happy time for Johnnie Greenhead and his spouse when at the age of six weeks their remaining family were able to fly, for now they were not only able to escape from their four-legged enemies by flight, but were on a more nearly equal footing with the duck hawks.

Every dawn they flew away from the lake and surveyed the surrounding country, sometimes swimming or feeding in one of the many lakes of the vicinity. According to the traditions of their race, the parents taught their family to rise high at once on taking flight and to fly above the range of a shotgun. Moreover, they taught the equally important habit of circling over a place and examining it carefully before alighting. Their excursions led them farther and farther away until they were well acquainted with all the country for many miles about.

One dawn, while flying over a small pond near a cabin, they saw some objects in the water that looked like ducks. Forgetting their usual caution they settled, almost to the water's edge, when there was a flash and a deafening noise and Johnnie and several of his family felt the sting of shot in their flesh. Fortunately the shot were small and the ducks were at the opposite of the pond. None were killed, but for days they were sore. Johnnie had learned the lesson of decoys, a lesson most ducks iever learn, and never again would he make the mistake of alighting without carefully examining 
every inch of the ground, even tho other ducks were there.

Soon this little family were joined by a flock of ten youngsters whose parents had been caught by the old hawk at the head of the lake. Autumn was here and the wild rice was ripening everywhere. Then for hours they would swim among the wild rice, securely hidden from their enemies, and reaching up they would let the ripe grain literally run down their throats until they could hold no more; or if fancy directed, they would suddenly poke their sensitive bills deep into the mud, turn their tails straight up, and feel about for small animal life or sweet roots. Tho these ducks are practically vegetarians, they sometimes vary their diet by eating some of the small life that crawls on the bottom of shallow ponds. When fed to the full they became happy and spent much time in noisy clamor or in half running, half flying, diving and splashing about in high glee, for mallards are the most playful of ducks; but always one of the parents stood guard against possible danger.

Finally winter came and froze the lake and covered the wild rice with snow. The teals, among other birds, had long since departed for the Southland. But not until grim necessity required did Mrs. Johnnie announce the time of departure for the South. When they passed over the old home Johnnie wanted to stop. In fact, they did settle in the brook by the old grape arbor, the only ducks I ever knew to alight on the farm. The boy was in the grove and slipped up behind the wild gooseberry bush to watch. There was Johnnie, easily recognized by his large size, with his family. All seemed perfectly at home save one old duck, doubtless the mother. She could not share 


\section{KNOWING BIRDS THROUGH STORIES}

Johnnie's feeling of security, for she had not been raised there.

The boy, in his interest, leaned out too far and this mother saw him. "Quack, quack," clear and sharp as a bugle's blast, and the flock rose like a flash and were gone! Tracks about the corn pen showed, however, that Johnnie brought his family home once more that night to feed at his favorite dining place before they departed into the great unknown. 


\section{IX \\ JIMMY THE GOOSE}

NE day late in April the boy saw a flock of geese settle in the pond in the large woods pasture not far from the river. This particular flock of geese had been late in starting north, and as the farmers were already busy putting in their crops, they were not bothered. The boy alone knew of their arrival. As he watched them day after day from his hiding place in the bushes, he began hoping they might stay all summer. He had no gun and was careful not to tell any one else of their presence.

Every morning the members of the flock showed great impatience with the leader because she persisted in staying about this pond; but as food was plenty and the days were pleasant, by the time she was ready to lead them to the nearby feeding grounds they had quite forgotten their impatience and were glad to spend another day in the green wheat field beyond the woods. Before the end of the week one old goose and her gander had decided to remain for the summer. After investigating every clump of bushes and brushpile within a hundred yards of the pond, a place was selected under some bushes in the corner of a rail fence enclosing the pasture. A depression was wallowed out in the earth and a little grass piled in it. When this was lined with down and feathers it constituted the nest.

When three or four days later the homesickness of the leader of the flock who had been hatched here was some- 
what abated, and he decided it was time to hie away to the northern breeding grounds, two eggs had already been laid in this nest, and of course no mother would leave her prospective family, so this pair stayed. When there were six eggs in the nest, the boy told his secret to his mother, who promptly removed them and placed them under a sitting hen in the chicken house. Realizing at last that a mistake had been made, the pair of geese followed the call of the north, and built their second nest on the banks of some lake in northern Minnesota or Southern Canada; but the boy had their eggs and thirty days later they hatched into six fuzzy brown goslings. For a day or two these young goslings were exceedingly shy, but as the only thing they. ever received from the hands of man was plenty of food and tender care, before long they were as tame as any domestic goose could be expected to be.

The summer passed uneventfully, four of the goslings growing into adult geese. All fall and winter they were contented to swim in the pond, or to sit about the barn lot eating corn from the crib and clover hay from the stable; but when the call of the north brought the wild geese honking northward the next spring, these geese would answer every flock that passed over. One morning in March three of these geese could stand it no longer, and took wing and joined a flock that was passing over. Jimmy by some mishap or good fortune, according to whose viewpoint you take, happened to be in the corn crib at the time, and the door had been blown shut. When he heard the commotion and realized that his mates were leaving, his loud cries of protest filled the air, for he wished to go along. The boy, when he heard the unusual honking, came out of the house just in time to see his pets depart- 
ing. At the suggestion of his mother he cropped Jimmy's wings before letting him out of the crib.

Jimmy was forlorn for days, but finally made up for his misfortune by hanging about the house and making friends with the good mother. When she sat by the window sewing, Jimmy was quite sure to station himself on the outside. He would sometimes sit for hours just outside the window, watching her as she was about her work. She had the habit of tapping on the window to call Jimmy when she was ready to feed him. In time he associated tapping on the window with food, and from that time, when he wished to be fed, he would come to the window and tap, tap, tap with his bill until the desired food came.

There was an old lady in the neighborhood who always raised a large flock of geese and sold feathers. For years she had believed that if she could get a strain of half-breed wild geese she would not only secure more feathers, but when selling time came she might be able to sell the birds as wild geese for a high price. Accordingly she would not be satisfied until she owned Jimmy.

Aunt Leah possessed a donkey as well as her geese. Jimmy took no interest in her geese at all, but stayed by himself in the donkey's pasture. At first he was furious every time the donkey would bray, and the donkey resented Jimmy's noise every time Jimmy grew lonesome and honked. Sometimes the donkey would try to stamp on Jimmy, but he was too quick for her, and it usually ended by the donkey whirling to kick at Jimmy, who would grasp her by the tail and pound her with his wings. Often he would chase her all over the pasture in this way. But both were lonesome and in time grew to be the closest of friends. Wherever you saw the one the other was sure to 
be. Jimmy and the donkey fed together and slept together a whole year. In cold weather when the donkey found a protected place to lie, Jimmy sat at her side or even warmed his feet by sitting on her woolly coat.

Remembering the experience of the first spring, Jimmy's wing was cropped every year early in February, lest he leave when his own kind began to come north.

A new source of unhappiness came into Jimmy's life when the donkey was sold and taken to Nebraska to work at plowing. Jimmy was utterly disconsolate for a few days, and wandered over the pasture all day long, honking from sheer loneliness. One evening a flock of geese heard him and spent the night with him eating the young tender blue-grass. When they left shortly after sun-up, poor Jimmy tried his best to go along, but his poor cropped wing would not permit. After this, never a honking flock passed over in his hearing that he did not spread his wings and try to follow.

One day Aunt Leah bought two buxom young gray geese and brought them home. They were not adopted by the flock but soon got over into what had been the donkey pasture. In vain Jimmy had tried for days to find his beloved donkey. When his own kind had stopped with him, he had spent one blissful night dreaming of cool lakes, succulent food, and a flock of goslings in the far north. But something was wrong; try as he would, he could not rise high in the air, and at best could fly only in short circles and tumble to the ground. Every day he tried, always hoping that when the next flock passed over he could join them, but already the maples were coming into leaf and no more wild geese were going by.

Seeing these homesick strangers wander into his realm, 
his heart went out to them. His decision was quickly made. He ran to them with a cry of welcome. The attraction seemed mutual so he mated with both, and then was perfectly contented to remain on the farm and finally to run with the flock. For several years he lived the life of a domestic goose, and Aunt Leah, feeling sure that he would not leave his humble mates, never afterward went to the trouble of cropping his wing. He became the father of many hybrid geese that at first were the joy of Aunt Leah's heart, but when she found that they were mules and would not breed, her interest waned. True, they were handsome geese, larger than either parent. They had the beautiful black head and upper neck of the Canada wild goose with a larger and heavier body. Their feathers were flexible and thick like those of their wild parent, with an abundance of down-just the kind of feathers to delight a feather merchant. Nevertheless finally they were all sold to the butcher, and poor unfortunate Jimmy was placed in a city park where he remained, apparently desolate, the last I heard of him.

You may be interested to know more about Jimmy's relatives. We have several species of wild geese in our country. Jimmy was a Canada wild goose. Those geese are especially characterized by the fact that the upper part of the neck and the head are black with large white cheek patches. They are active birds and fly long distances, often flying fifty or sixty miles in an hour. They still breed by the thousands in some parts of the Northland. When I was a boy I have seen them in huge flocks, especially on the Republican and Platte rivers in Nebraska. In our old home in southeastern Iowa it was a common thing for these birds to alight in the wheat or cornfields 
to feed, and they often spent the entire winter on the Skunk river, roosting wherever they could find an open place in the ice, flying back and forth from the fields to the river every day. They usually did their feeding in the late evening or the early morning, leaving the cornfields soon after dawn. When flying they form a Vshaped line, the same bird usually flying at the point of the $V$ and leading the flock.

Often they are hatched and kept on the farm for years, but they do not breed well in captivity, tho sometimes they become really domesticated. It is wise, however, to keep a wing cropped to prevent them from leaving in the early spring or fall. Like all of the geese, in the summer they feed largely on grass, snails, crawfish, and such things as they can get at the edges of the ponds, but in winter they depend largely on seeds and grains. Very few of them now breed in the United States, except in the Yellowstone National Park, where they are protected, and in a few other localities; and if their breeding places are crowded farther north, they may become extinct in our country. 


\section{$\mathbf{X}$ \\ LADY JANE THE SWAN}

THE warm south wind has been blowing now and 1 again for weeks, and already the snow was gone except a few great drifts in the north side of the woods near the creek. Claytonias, anemones, and bloodroot were vieing with each other to see which could attract the attention of the earliest bees. Robins and bluebirds had come trooping north in untold thousands, and every few minutes the boy playing in the yard would hear the honk, honk, of wild geese and a long V-shaped line would come in sight on the southern sky, soon to fade away in the north, while wild ducks were seldom out of sight more than a few minutes at a time. The country was quite thickly populated, and most of the water fowl, growing wise, had decided to go on to the lakes of Northern Iowa and Minnesota in search of new nesting grounds. Already the trumpeter swan had begun to be so scarce as to attract attention whenever a flock passed over.

A few miles north of the forks of Skunk River was a pond which at high water covered several thousands of acres and even in the middle of the summer was more than a mile across. This pond, known locally as Holmes Lake, was never deep even in the middle, and over much of it. a man in high top wading boots could safely wade. Sweet: 
flag, rushes, and cat-tails lined the shore and here myriads of minnows and pollywogs played or hid under sunken logs or clumps of broken reeds. The nearest farms were two or three miles away, and so it is small wonder that some of the bolder of the water fowl hesitated to desert so ideal a home for unexplored regions beyond.

Suddenly the boy was attracted by a loud clear trumpet call like the blast of a French horn, and almost at the same time a voice was heard crying "swans." Soon he saw a dim line approaching which gradually broke into twenty large birds with long necks stretched far ahead and legs sticking back beyond the tail. Even tho they were high in the air, they flashed white as snow in the sunlight. The boy did not have long to watch so novel a sight, for the giant birds flapped their wings with a steady beat that carried them many miles an hour. It was not many days until the rumor went around the neighborhood that a flock of twenty swans was hanging about Holmes Lake. Every hunter in the neighborhood rubbed up his old gun, and at the first opportunity tramped many a weary mile in hopes of gaining the fame of killing a swan. But these birds were no novices. Years of experience had taught them wisdom, and when corn planting time came and the hunters had to turn farmer no hunter could boast of a single trophy.

As the days passed, one pair after another of these swans grew restless and, when they could not get the flock to go, quietly slipped away into the northern sky. At last only two pairs were left, but they refused to leave so delightful a feeding ground.

At some distance from the shore was a small island, with just a few scrubby bushes growing on its banks. After 
much consultation a pair of swans wallowed a shallow depression in the earth under one of these bushes, lined it with rushes, weeds, and grass, and inside this built a nest of softest down plucked from the mother's own body. Here was deposited a great whito egg larger than the largest goose egg. The next day the other pair set up housekeeping under a bush not ten feet away. Every other day the mother swans laid an egg until there were eight in each nest, when they settled down to brood their eggs. For thirty days the mothers spent most of their time sitting on the nest dreaming the dreams of any normal mother, slipping off only for a short time every day to gather a hasty meal from the steaming waters, while their disconsolate mates spent much of the time loitering about looking like a married man in a department store on bargain day.

Tho the mother left the nest for only a few minutes; she always saw to it that the eggs were covered with down to keep them warm and that enough grass and reeds were scattered over all so to make the nest look like any other spot on the island; for she well knew that when a wildling leaves her nest there is no knowing how long she may be compelled to delay her return, and there is no telling what prowling thief may visit the spot in her absence.

One day early in May Dad Oswalt, as he was riding past the lake, was surprized to see a swan fly out of the tall rushes and a number of fluffy balls of down scurry to cover as fast as their little legs could paddle over the water. He had no time to stop, but registered a vow that he would realize a lifetime ambition of owning a pet swan. Not many days afterward he took the boy and rode 
over to Holmes Lake. Quietly slipping through the bushes, they came upon the shore unexpectedly, and sure enough there were four old swans and a dozen young, leisurely feeding near the bank. A swan would thrust its long neck full length under the water and strip off the tender shoots on the rushes and flags, or catch insects, pollywogs, snails, or any other eatable thing that came handy. It was a pretty sight to see a great white bird thrust its long neck under the water and stand with its tail in the air with bubbles coming up every few moments showing where it was feeding. First one foot and then the other would paddle a bit to help the bird keep its balance or to hold it under the water. Dad did not want to shoot any of the birds and had no canoe. He had hoped to catch the birds feeding on the land and by a bold rush secure some of the young before they could get into the water, but altho he and the boy spent most of the day hiding about the lake, the swans, led by that good spirit which protects the wildling, kept well away from the shore.

One thing occurred, however, which interested the boy greatly. Along in the early afternoon a great snapping turtle, quietly slipped off a log and started swimming toward the swans. Both Dad and the boy watched intently. Quietly it moved with only its head sticking above the water until within perhaps twenty feet of the happy family. Then it settled down till only the tip of its nose could be seen. Stealthily it moved forward till within five or six feet, when it disappeared. In a moment a young swan gave a flop and a squawk and disappeared under the water. The wily old turtle had risen from beneath and catching him by one foot had settled to the bottom, pulling the poor bird under, allowing the water to finish the story. 


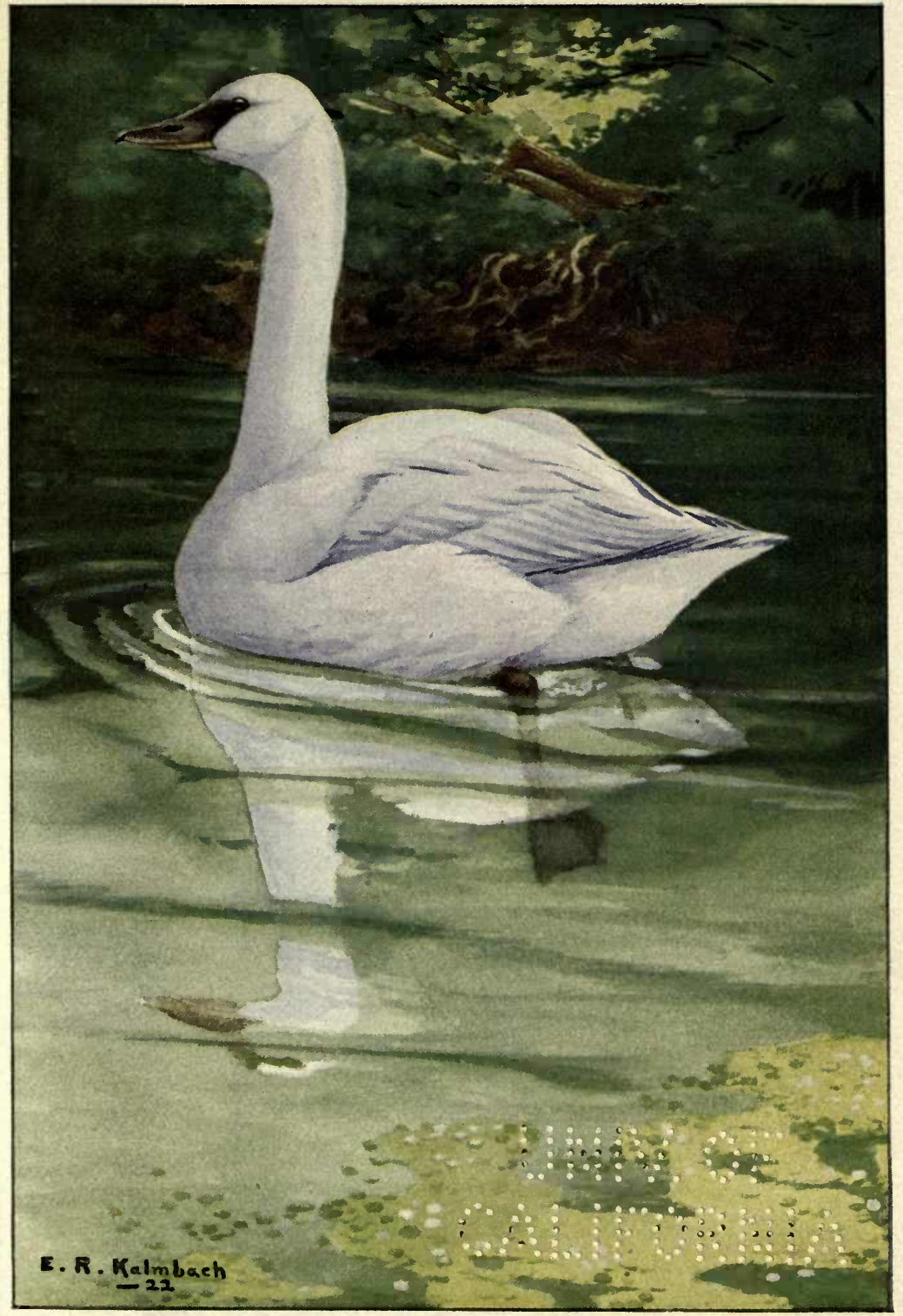



When the swan was drowned the turtle could feast at leisure.

Very many young wild geese, ducks, and other water fowl lose their lives in this way where turtles are abundant. In fact, I have a friend near Ruthven, Iowa, who decided to make use of a small lake near his house by raising ducks by the hundreds, expecting the ducks to live on the abundant food on its shores. As soon as his young ducks were allowed to go to this lake the turtles began catching them, and soon had caught so many that he gave up the attempt and sold the few remaining ducklings.

Early in the fall, Dad Oswalt came back to the lake determined to get a young swan. They were just learning to fly. After trying in vain to catch one, he finally shot it in the wing and it fell some distance from the lake. It was injured badly enough so that it could not fly; but when he tried to catch it, he found that he had a real battle on his hands. Even a young swan will weigh from twenty to twenty-five pounds, and its wings are quite powerful. The swan put up a terrific fight, biting and pounding with its wings until Dad feared he would have to kill it after all. Bruised and bleeding, he finally subdued the bird, and tying its wings over its back, took it home. Binding up the broken wing with a splint he placed it in a pen and fed it as one would a goose or a duck.

Those who have never seen a young swan doubtless do not realize that they are not the beautiful, white bird we often see gliding over the lakes in our city parks. A young swan is not white at all, but an ugly brown, and a young trumpeter swan remains that color until it is almost a year old. That explains why the young can so quickly disap- 
pear among the rushes and cat-tails in the lake, for even before they are feathered they have that peculiar dull tint of brown that blends with almost everything in nature. This sares many a young swan from being caught by hawks or coyotes. The coyote has a keen sense of smell but does not locate his prey by this means alone. When a young swan is down wind from a coyote it can remain among the rushes and be perfectly safe as long as it sits quietly. The old swans do not have this danger, for no hawk is large enough even to hope to kill a swan and a coyote must be brave indeed to make the attempt. A swan's beak is exceedingly powerful, and, driven by the long neck, can strike a powerful blow. More than that, the wings are so strong that they are able to break the bones of even a coyote if they strike him squarely.

Dad Oswalt named his swan Lady Jane. Lady Jane had been in her pen only a few days when Beaver, a sixmonths-old pup discovered her whereabouts. Now Beaver never stopped to question whether this young swan was an intruder or not. It was merely something new, and even tho it might belong to the master, surely it would do no harm to have a little fun at its expense. Accordingly he jumped into the pen and rushed on Lady Jane with the full intent of frightening her out of her wits and having great sport wallowing her and pulling her feathers, as he had sometimes done with a chícken in the barn lot. Several well administered lessons had taught him that chickens were not to be bothered in this way, but no one had said that he must not play with a swan. He would take the chance, anyway. Grandmother saw him bound into the pen, but kept out of sight and watched to see what would happen. Lady Jane had not lived on an island and 
seen her mother chase off the coyotes for nothing. She did not even think it necessary to hiss at this awkward puppy, but raising herself to full height and throwing her head well back, she half raised her wings and waited.

Beaver did not quite like the turn events were taking. He had taken it for granted that she would run as soon as he came near; but he was no coward, and evidently it would be necessary to teach this bird a lesson in manners, for no bird had the right to consider itself above fearing a six-months-old pup. Hesitating a moment, he sprang straight at her, meaning to catch her by the neck. While he was in mid-air out darted the long neck, driving the hard beak full into his face, cutting an ugly gash and knocking the puppy howling to the ground. The swan was not willing to stop here, tho the puppy would have been glad to call it enough. Catching him by the back of his neck, she beat him with her wings till he fairly howled with pain and fright.

As soon as he could get free the thoroughly frightened puppy ran howling to the house. Both pup and swan had learned a lesson. Nevermore would the pup bother a great strange-looking bird, and the swan knew how to fight dogs.

Lady Jane soon became so gentle that she was allowed the freedom of the place. She seemed to feel perfectly at home, and seldom showed any disposition to wander. There was a small pond near by where she could satisfy her appetite for swimming and fishing, and there was plenty of corn about the stable. What more could a swan desire?

She soon became much attached to the master. Even before she had put on her grown-up plumage she followed him wherever he went. It was a comical sight to see the 
old man get on Betsy, his racking mare, and start for town with the swan chasing behind, trumpeting and flapping her wings. The bird never flew in order to keep up, but ran behind flapping her long wings. Sometimes if he rode too fast she would catch the horse by the tail and hang on, flapping her wings, and touching the ground only every few rods. When the old man went into a house Lady Jane had to content herself by sitting on the outside, or, as she more often did, by waiting at the side of Betsy, and wo betide the dog who dared to disturb either. More than once some over-ambitious dog, attracted by the novel sight of a swan following a man on horseback, gave chase. But he always went back a sadder but wiser dog, for Lady Jane looked on the intrusion as a personal insult which she felt in duty bound to avenge. Strange to say, never once did she come out of the fracas second best, for no dog ever proved quick enough to dodge her lightning beak or to escape the terrible hammering of her mighty wings.

As spring came on Lady Jane grew apace. When fully grown, she weighed over forty pounds and could eat corn off the brim of Dad Oswalt's hat when the hat was on his head, and Dad Oswalt was a man six feet tall. Now she was snow white, all but her feet and legs and bill. These were black. The bill is longer than the head, and is flat like that of a goose or a duck. Yet where it joins the head it is thicker than it is broad. This is true of all swans.

Lady Jane could swim faster than any one could row a boat or paddle a canoe. She seemed to like to race in this way, always managing to keep out of reach without getting so far ahead as to discourage her pursuers.

As spring drew on, she developed a desire to fly. She 
never tried to rise out of the water as a duck would, but ran or swam forty or fifty yards in the wind, flapping her wings before finally taking the air. It is doubtful whether this great bird can rise into the air without this preliminary run. It is certain Lady Jane never did.

When the wildlings began to come north, Lady Jane became very restless, and trumpeted a great deal. She would take long flights, but by sundown was always sitting in her own pond, with her long neck curled over her back with just her black bill sticking out of the feathersthe only black spot on a ball of snow.

One morning, just at sunrise, all were startled by a regular trumpet concert. Some were trumpets as heavy as a bass horn, others were as shrill as a flute, and there were all notes in between. One who has never heard such a concert can scarcely imagine its power. These swans can trumpet as loud as a professional horn player. In fact, their voices can be heard for two or three miles.

Peeping out of the window, the boy saw a large flock of swans sitting in the pond. They had doubtless been attracted by Lady Jane. Immediately a gander started making love to her, and she acted perfectly delighted at finding others of her kind.

The flock stayed about the pond most of the forenoon. When the flock left, Lady Jane hesitated, but when they circled back over the pond calling, she finally followed. No one ever again saw her so as to identify her, tho one night in autumn a flock of swans spent the night in the pond where she had lived so long and some of them helped themselves to the corn in the crib.

Of course you have already guessed that swans are web-footed swimming birds, belonging to the Anseres. 
Their sub-family name is Cygnince. The trumpeter swan is now almost extinct in the United States. One day, early in March, 1920, I was crossing the campus of the Nashville Agricultural Normal Institute at Madison, Tennessee, when I was startled by the almost forgotten note of this bird. Scanning the sky, I located two trumpeter swans. They came almost directly over my head and passed out of sight to the northwest. They seemed almost like phantom birds, echoes from the dim past. I have often wondered where these two birds came from and where they were going. Their summer feeding grounds changed, their winter feeding grounds no longer safe, the race has all but given up the struggle. It is to be hoped that these lone wanderers found safety in some place, and that they may live long and become the progenitors of a large family, for the trumpeter swan is one of the most beautiful of our many valuable birds.

We have in America another wild swan that is smaller than the trumpeter swan. It is known as the whistling swan. Many of the swans we see in our city parks are of neither kind, but are of European origin. 


\section{XI \\ THE SHITEPOKE}

UR home farm consisted of two "eighties" that cornered each other. The buildings were located on one, the other was mostly pasture. Wymore's Branch, a beautiful little creek in those days, cut across the pasture "eighty," and a high hill rose abruptly from this creek on one side while the other side was a low-lying bottom. A slough ran lengthwise through this eighty, meeting the creek just before it left the farm. There was a very valuable spring in this slough which flowed as freely in the dry time as it did in wet weather. Near the place where the slough ran into the creek was an acre or two of land that was usually swampy from the overflow of this spring. The creek itself was deep enough to be the favorite fishing place of the small boys of the neighborhood, and our best swimming hole was just at the lower edge of our farm.

We usually had a potato patch and garden truck growing on the bottom land near this spring, and so business or pleasure called me there several times a week throughout the summer. Mother and I used to take our lunch and walk down to this garden and spend the day. We did plenty of work; but, wise woman that she was, mother knew that the way to get plenty of work out of a small 
boy was to allow him a play time as well. Consequently after lunch at noon we often went down to the creek where mother told stories of the wonders of her childhood days in the mountains of Tennessee.

Sometimes I would wade down the creek and leave mother sitting on the bank. It was on one such occasion that I first saw what to me was the queerest looking bird I had ever seen. About fifty feet from the old swimming hole was a very peculiar knoll about forty feet in diameter that was so very symmetrical that $I$ am now inclined to think it was a mound of the prehistoric mound builders. In fact, I have made up my mind that the first vime I get back to the old home, I am going to dig into this mound and find whether it is a prehistoric mound or just a knoll. A few feet from this mound was a small round pool about the size of the mound itself. This pool was always full of pollywogs, crawfish, and small minnows. As it never went dry, minnows that found themselves stranded there after the creek had overflowed its banks could always find plenty to eat until an opportunity came to leave during the next high water. This bird was standing on one foot at the edge of this pool, as immovable as a stick.

The first thing that attracted my attention was his very long, slender legs and his even longer slender neck. His bill, too, was long and pointed, and he wore a crest on the back of his head that stuck out like a plume. As the sunlight flashed over him he showed wonderful shades of green and purple, but when a cloud came over the sun his head and wings and back appeared almost black. It was by the merest accident that I noticed him before he saw me, and curiosity coupled with a knowledge of the wildlings, led me to stand perfectly still and watch him. I do not 
think I was more than fifty feet from him, but as I had been walking along the edge of the creek, my head being lower than the bank, he had not seen me nor heard the sound of my bare feet on the mud. It seemed to me that we stood there an endless length of time, for no reason that I could understand unless it could be that he was asleep, and because $I$ was so anxious to see what he was about I stood almost as still as he-which probably explains why it seemed so long. Finally, like a bolt of lightning out of a clear sky the long neck darted forward and the bill and most of the head flashed under the water. Quicker than I can tell it, he straightened up with a crawfish in his bill. I was fisherman enough to know that if one expects any luck with the finny tribe he must be quiet when he is fishing, but I have never been able, even to the present day, to know why he prefers to stand on one leg with the other drawn up tight to his body when fishing. I was so surprized that I made an exclamation sufficient to attract his attention and away he flew up the creek, keeping near the water so that his body would not be seen above the sky-line. A comical sight he presented, his long legs dangling, his neck sticking out ahead, and his great wings, large out of all proportion to the size of his body, slowly flapping. I followed as rapidly as I could until I reached the place where mother was sitting, eager to call her attention to the bird before it could get out of sight. To my inquiry of "What is it?" she said, "A shitepoke," and she presumed a pair of them must have a nest somewhere in the swamp near the crabapple and plum thicket, just over the fence, in the edge of Graham's brush.

We went back to work, but after that every time I got a chance I would slip down to the creek and watch this 
odd bird and his mate. I found, however, that it was no easy task to slip up on them without being observed. Usually the first I became aware of their presence was when I heard a peculiar croaking grunt and saw them awkwardly flying down the creek. Sometimes, however, I was fortunate enough to observe their fishing. It was always the same old story, the bird never tried to follow up and catch his prey. Instead he always stationed himself at the edge of the creek, or, more frequently still, on the bank of this little pool, his favorite fishing ground, and watched for his prey to come near. The shitepoke must be a bird of wonderful patience for I have known him to stand immovable as a post for more than an hour at a time. He was so absolutely immovable that it seemed impossible for him to be awake; but always, sooner or later, I was startled by the lightning-like dart of his long neck. He certainly is an expert spearsman, for never once did I see one of these birds fail to catch his prey. Sometimes it was a minnow, sometimes it was a tadpole, but more often it was a frog or a crawfish. I do not know whether this was because he especially preferred them to any other food or whether it was because they were more plentiful. If he was fishing for his own dinner he promptly whacked his prey against the ground two or three times and swallowed it; but as the summer came I found he very frequently would beat his prey until it was dead and lay it on the bank until he caught something more and then taking both in his long bill, would fly lazily down the creek. Of course I was anxious to find his nest, and as I knew he was carrying food to his young, I sought long and earnestly. But I was under the impression that a bird with so long legs as he must necessarily nest on the ground, 
for certainly, it seemed, no nest placed in a tree could accommodate such dangling legs. I had been told that he was a heron. In fact, while father and mother both usually called him a shitepoke, they knew that he was a green heron; but neither had seen a nest and both supposed he nested on a tussock in some swampy place like most of the waders. I tramped over the swamp ground in the neighborhood of the plum and crabapple thicket time after time to no effect.

I think I have already told you that I had been taught that there is a great tribe of waders, so called because of their long legs, and that they are fishers which live in shallow swamps and on the banks of streams. I had also seen a picture of a flamingo's nest, and was under the impression that all of this family built mud and grass nests on the ground like the flamingos.

I watched these birds for five years before I was successful in finding their nest, and when I did find it, there were five nests all within thirty or forty feet of each other, the oldest one almost rotted and falling out of the tree. Evidently there was a nest for each of the five years I had watched the birds. Lest you make the same mistake as I did, I must tell you that the nests were in very thick brushy crabapple trees about ten or twelve feet from the ground. They were of the size of a very large crow's nest and were built of sticks. The top of the nest was larger than one would naturally expect for so small birds, doubtless because their long legs make a bigger nest necessary than would otherwise be needed.

There was another mistake I made for several years. There is a similar bird not quite as large and not of the same color, but so shy that I have seldom been able to 
see him except at a distance, but I did hear his unearthly noise. This is a bird we knew locally as the thunderpump. In reality this bird is a bittern, and he fishes along the banks of streams very much as did my green heron; but he feeds more like a duck, putting his long bill down in the mud and feeling about for worms, snails, and anything he may be lucky enough to find. He gives utterance to a heavy rumbling noise that can be heard for a long way. As both birds lived along this creek, and as the thunderpump was so shy that I did not get to see him when I would creep up carefully to find out what was making the thundering noise and as I often found the shitepoke, I was sure that he was the bird.

The shitepoke is found over a very large part of our country. He does no harm, living as he does a quiet secluded life and feeding on snails, small fish, etc. In the Middle States he is probably the only long-legged bird anywhere near his size that you will find in such locations. Of course there are other herons of similar appearance; but they, instead of being twelve or fourteen inches in height, are two or three feet tall. The shitepoke is found in secluded places and deep in the woods about ponds or along streams.

\section{Key to the Families of Herodiones}

Prataleido-Spoonbills.

With the upper mandible grooved to the tip, the bill broad and spoon-shaped at its end.

THRESKIORNITHIDE-Tbises.

With upper mandible grooved to the tip, but with bill narrow and bent downward, not spoon-shaped at its end.

ARDEIDE-Herons.

With the upper mandible not grooved to the tip, the neck and most of the head feathered, and the hind toe on 2 level with the others.

CrCONIIDR-Storks and Wood Ibises.

Like ARDEIDE, but with the head and part of the neck bare, and the hind toe elevated. 


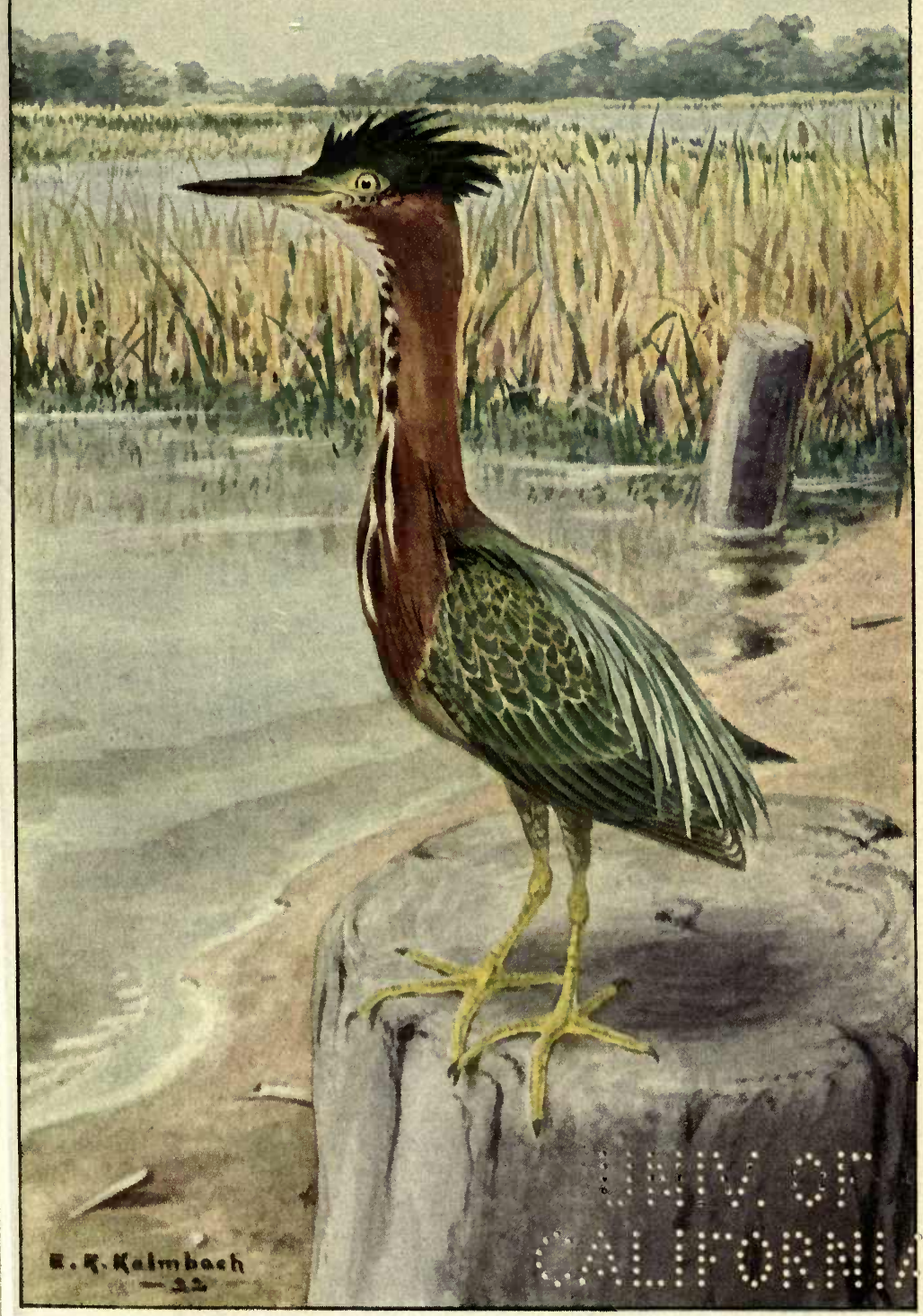




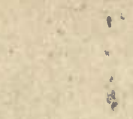

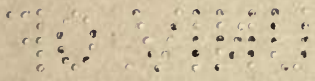

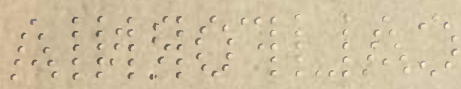




\section{XII}

\section{THE SILENT DANCER}

NE day late last spring, as I was walking across the campus toward my class room, I was startled by hearing a long-forgotten sound. It came like an echo of former days and brought with it a flood of fond memories of childhood. I stood still in my tracks and began scanning the Southern horizon as I had done hundreds of times in my childhood for my long forgotten friends. Presently the cries came again and I succeeded in making out a dim line of birds circling in the southern horizon. Higher and higher they mounted for perhaps ten or fifteen minutes and then started on north straight toward me. Nothing that I had seen for a long time was so great a surprize, or gave me so much pleasure, except the sight of the two trumpeter swans mentioned elsewhere in this book. Fortunately I succeeded in calling several persons to witness the sight.

By the time the birds were directly overhead they had fallen low enough that one could see their long legs sticking out behind and their equally long necks and bills sticking out in front. When they were almost directly overhead the leader gave a signal and they all broke rank and again started circling in order again to gain height before making another dash northward. They circled 
about until they were so high that they were almost out of sight and then the leader gave the signal and started north again, and before they had gone a hundred yards all had fallen into line. Every bird seemed to know his place and promptly flew directly to it. Sandhill cranes, for this is what these birds were, usually fly in a V-shaped line, but it differs from that of the Canadian wild goose in that one side of the line is very long and the other very short. Some wise old bird, usually a gander, flies at the point of the $V$ and usually no more than two or three fall in almost directly behind him. The others form a long line sloping back at angle of about forty-fire degrees.

When these birds are going south in the fall, especially if they have been surprized by an unusually cold spell, they fly rapidly, often going two or three miles before circling, but they never fly long distances without circling, as they gradually fall toward the earth when flying straight ahead. In the spring time especially, if the weather is warm and they come north early and so are in no hurry to reach their nesting place, they circle very often and then merely sail between times. In the spring I have watched sandhill cranes for twenty minutes or more from the time they came in sight on the southern horizon until they faded out in the north, whereas on a cold fall day they would cover the same distance in half this time. I do not think it is because these birds can fly better in cold weather but merely because they are in a hurry then and so do their best.

When I was a boy thousands of these birds passed over our place every fall and spring. They do not migrate early in the season, and so we always regarded it as a sure sign that we would have no more cold weather when we 
saw the first flock of sandhill cranes. These cranes never nested in our part of the country, tho formerly they nested in parts of Iowa and Illinois. Later they confined their nesting to the sand hills of North Dakota and Western Nebraska. There are a goodly number of small lakes in that district, and it was in that region that the sandhill cranes have made their home for ages. Later still, they seldom bred even there. The territory lying between the Missouri river and the Mississippi has always been a favorite flying place for migratory birds. Located as we were between the Mississippi and the Des Moines rivers, we were in the regular beaten path of the sandhill cranes. From the South they came up the Mississippi river and then followed the Des Moines directly across the State of Iowa until they came to the Missouri and followed it up to the vicinity of their nesting grounds. In this way they could always find plenty of food and water.

As these birds came south in the fall they often stopped in the cornfields and filled up on corn before going on. Oftentimes a bluster of cold in the sand hills would start them southward; but as this cold wave did not reach as far as southeastern Iowa, they found it convenient to loiter along the way, as food was more abundant there than it would be when they reached their winter home. Occasionally they alighted in the wheat fields on their trip northward in the spring. This was especially true if there came a few days of cool weather after they had started north.

We usually think of the long-legged, long-billed birds as waders, and expect them to feed on fish and other water animals; but the sandhill crane feeds to a considerable extent on grain and grasses. 
When a flock of cranes alight, they at once post their sentinels. If it is a small flock of not more than twentyfive or thirty, there is often only one that stands guard, but if, as sometimes happens, the flock numbers several hundred, there are several sentinels on duty. They stand bolt upright while the flock is feeding and as they are almost as tall as a man they have a good view of the surrounding territory. Perhaps no bird has keener eyesight and is more cautious than the sandhill crane. I have spent hours trying to creep up close to a flock of these cranes, but I never succeeded. This was not wholly due to my stupidity, either, for in all the years of my childhood I knew but one hunter to kill a sandhill crane, simply because other hunters could not get within gunshot of them.

These birds have a peculiar habit of dancing during the mating season. To a certain extent this custom is common among the cranes and some other birds, but the sandhill crane goes about the matter with a seriousness and a precision that puts him in a class by himself. My friend, Mrs. Phoebe Clark, president of the Tennessee, Kentucky and Northern Railroad, gave me the following narration of a sandhill crane dance she witnessed some years ago in the sand hills fifteen miles from Larimore, North Dakota. She said:

" $I$ was driving with a horse and buggy one afternoon when, as I rounded the point of a sand hill in full view of a small creek, I saw a flock of some nineteen or twenty sandhill cranes drawn up in a straight line on the prairie perhaps a half mile from the water. When I first saw them they were standing in a straight line as rigid as a company of soldiers standing at attention. I stopped my horses at once to watch them. Presently the bird at the head of the line 


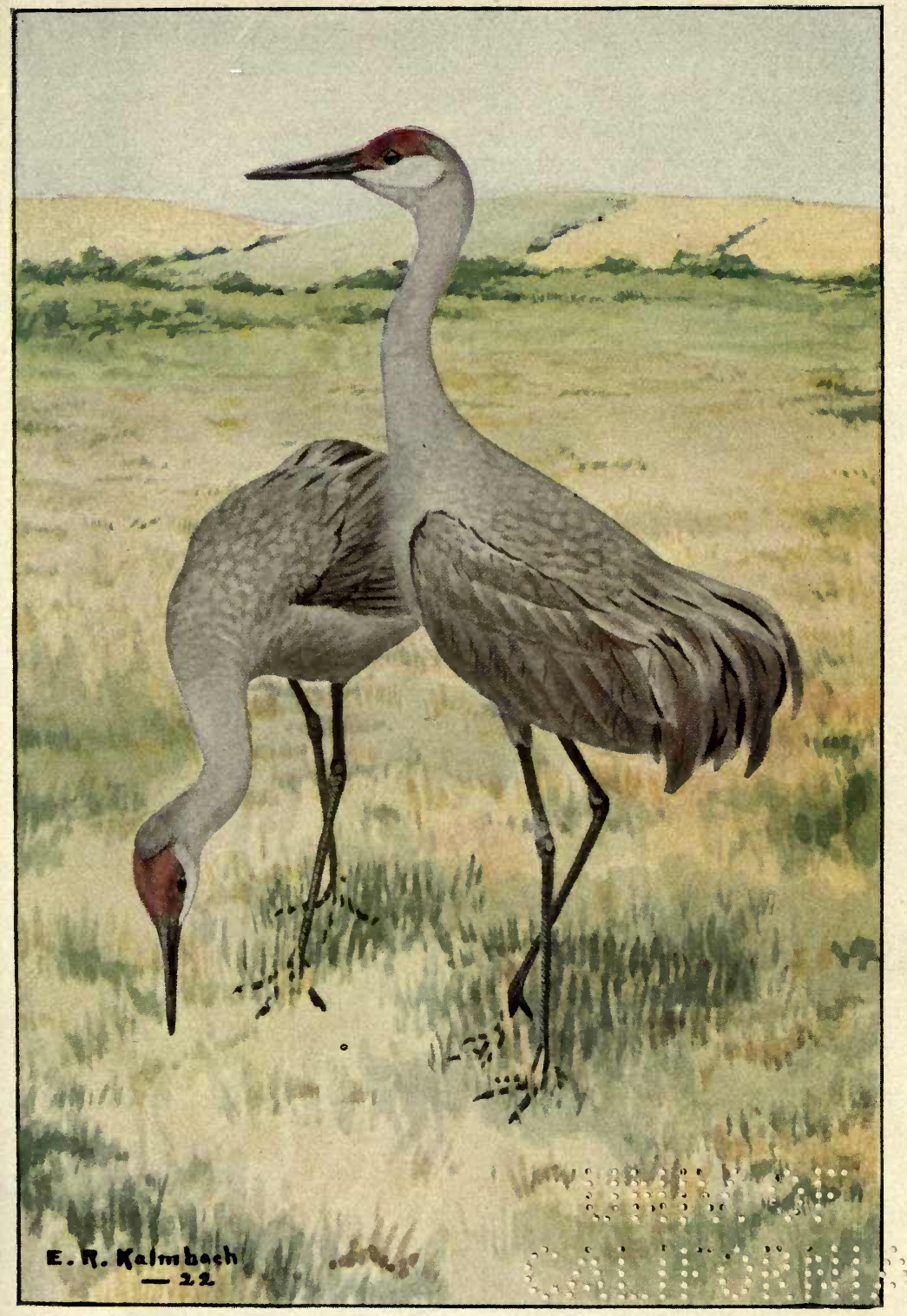

PAIR OF SANDHILL CRANES AT HOME 

walked out in front of the others and solemnly began dancing. He would hop first on one leg and then on the other, jump up and down, and whirl about, sometimes flapping his wings. This procedure continued from three to five minutes, when he solemnly marched back and took his place at the head of the line and the bird next to him walked out and went through the same performance. I sat there for more than an hour and watched until every bird in the line had taken his turn and performed his dance. When the last one had finished, the bird at the head of the line started the dance over again. After two or three had danced the second time, feeling that I could wait no longer, I drove away leaving them undisturbed. During all this time not one of the birds had uttered a sound."

Shy as these birds are at other times, during their love making and dancing season they do not seem to station any sentinels at all, but trust to the God of the wildlings to take care of them. They nest in rookeries, often large numbers nesting in a small space. The nests are built in marshy places on tussocks, often a dozen or fifteen nests being found in a group. This, however, may not be because they love to be together so much as because there are few choice places to nest.

I happened to be camping on the Brazos river, Texas, in 1903, when the sandhill cranes began coming in from the north, and I was surprized at their enormous numbers. There was not an hour in the day or night that a dozen or more flocks did not arrive, and as the new arrivals were not only noisy but were greeted by thousands of birds that had already arrived, they kept me awake most of the night. I had always heard that there are occasionally white sandhill cranes but, until on this occasion, $J$ had never seen one. I saw three snow white sandhill cranes that week. It has been suggested to me that they were 
white whooping cranes that had happened to be with the sandhills, and of course as I did not shoot any of them I can not prove that this is not true; but I saw at least one of them arrive from the North with a flock of sandhills and he flew in his regular place the same as any other member of the flock. I had a good pair of field-glasses with me and so was enabled to see these birds very clearly, and was thoroughly convinced in my own mind that they were white sandhill cranes. This would be nothing unusual among birds, for white robins, white grackles, or even white crows are occasionally seen in this country. In fact, there was a white robin that lived for three or four years in Montclair, New Jersey, a residence suburb of New York City. This bird finally was found dead one morning in the yard of a friend of mine who told me of the incident and of the interest the bird had excited in the community. Even white crows are sometimes seen, and there is no reason why sandhill cranes may not occasionally be white. I am aware that no albino sandhill cranes have ever been reported by an ornithologist, but my father, who was a keen observer of birds, and knew well the whooping crane, our large white crane, says he has seen several white sandhill cranes in the pioneer days when the cranes came into our neighborhood in countless thousands.

Within the last ten or fifteen years most of the breeding grounds of the sandhill cranes have been settled, and the same is true of their winter quarters. For this reason these cranes have become almost extinct. Dr. Harry C. Oberholser, bird expert of the United States Department of Agriculture, tells me that there are probably only a few left, except in Florida. There is a little brown crane, however, that is very similar to the sandhill, so similar in fact, 


\section{THE SILENT DANCER}

that it is almost impossible to tell them apart unless the birds are shot and measured. This crane is still found in considerable numbers during the migration season and in winter in different parts of our country. 


\section{XIII}

\section{THE SORA RAIL}

T A-WEET-EEP, Ka-weet-eep-eep-eep-eep-eep, Cheep1 cheep-cheep-cheep. I had slipped down through the woods and underbrush to a small pond and was sitting half concealed on a log, listening to the night voices and watching the fish leap out of the water here and there as they sprang for the flies that were bobbing back and forth over the surface of the pond. The twilight was just beginning to gather. The wail of the whippoorwill came from a rail fence a few rods away, from the tree above a screech owl called to his mate, while the bull frogs mingled their heary bass with the treble of the tree toads and the strident call of the katydid and of the green grasshopper. From up the river came the "whoo-whoo" of a great owl, while in the pasture beyond a killdeer was protesting excitedly because the cows were feeding toward the special preserve he claimed as his own.

No music is so restful to tired nerves and so soothing to troubled spirits after the toil and worry of a hard day than this song of the wildlings, God's chorus of the great outdoors. To one who has learned to seek and love it there is no enjoyment more keen and nothing that will revive courage and give new health and hope so effectively as to slip off alone into such a nook as this and spend the eventide. You may talk of the lure of the great white 
way and the pleasures of Coney Island or similar places; but to one who truly knows and has learned to understand something better their appeal, which only intoxicates and tortures tired nerves and over-wrought brains to madness, in no way compares with nature's evening entertainments.

Ka-weet-eep, Ka-weet-eep-eep-eep-eep, Cheep-cheepcheep-cheep came again nearer and nearer and more earnest than before, and a fantom bird darted round the foot of a stump and went racing over the sand, picking up a worm here and a bug there and, like a streak, whisked out onto the moss and lily pads, never stopping for an instant except to snatch a snail from the stem of a cat-tail or a crawfish from the shallows beneath. A queer apparition indeed he made with his legs so slim and so long that he appeared to be running on stilts, and his delicate, slender finger-like toes so nimble that they could take hold of the driftwood and lily pads as easily as a squirrel clings to his tree. Even more remarkable was his body-compressed until it reminded me of a croppy or a sunfish. The Creator truly has adapted each creature to the life he is to live. The goose, the loon, and the rest of the swimmers have a broad, flat breast and body so that they will float easily over the surface of the water. Their body is usually broader than it is deep. This creature which had so suddenly appeared from nowhere clearly was made for racing. His body was compressed until it seemed to split the air like a knife blade. He was a sora rail. To one who is unfamiliar with these birds the expression "thin as a rail" means very little. When we used to split rails from the oak trees and build rail fences, I could never quite understand why things were spoken of as being as "thin as a 
rail"; but when I became acquainted with this bird the expression became very striking indeed. I used to wonder what he did with his food when he swallowed it, for truly he looked too thin to have room even for his food and his digestive organs.

With contented "tweet, tweet" he raced over the lily pads until he came to an open place and to my surprize without a moment's hesitation plunged into the water and swam over to where there were more lily pads and clambered onto them and went on his way into the darkness beyond. I could hear his contented chirp for some time, and then suddenly three or four more came running down the beach and took their way out over the lily pads as he had done. By frequenting these places I soon became aware that these birds were nesting in the end of the pond where it merged into a sort of a marshy place overgrown with reeds and cat-tails. Here weeds and grass in abundance had been heaped together on a bunch of broken reeds above the water, making a pile several times as large as the bird. The surface was hollowed out just enough so that the eggs would surely remain in the nest.

We are told that these birds sometimes nest some little distance from the water, even occasionally building in gardens under gooseberry bushes or in other well concealed places. The bird lays from fire to sixteen buffcolored eggs spotted with brown and lavender. The young birds leave the nest soon after they are hatched, and take their part in chasing back and forth among the rushes and over the lily pads in search of food. They live largely on the insect life that is so abundant in the water, but add to this various seeds, wild rice, and an occasional snail or 
crawfish. They are exceedingly shy birds, and even tho they are abundant they manage to keep themselves so well hidden that many people never see thei..

The way to find a sora rail is to not hunt for it, but quietly to sit down near the bank of a creek, or on the edge of a pond where such birds are known to live, and wait for eventide when they appear in abundance. They are not only found about marshes but are abundant in old meadows, especially where there are creeks or wet places near by. They are more easily seen in the later part of August or the first part of September when the wild meadows are being mown, for at this time the young are not yet able to fly and the old birds, being made more brave by the necessity of caring for the young, are not so shy. While one is mowing these wild meadows, these birds are often seen; and when they get into a close place, they suddenly drop into a hole or depression and lie perfectly flat, allowing the mower to pass over, often without ever being seen by the driver.

These birds may be recognized from others of their tribe by the fact that they are black around the base of the bill, this space extending downward on the foreneck in front and over the forehead. Their upper parts are olive brown, with streaks of black running lengthwise, and many feathers have narrow stripes of white on their edges. The side of the neck and the breast to behind the eyes are of a bluish ashy color, with circular spots of white. The middle of the abdomen and under the tail are white, the sides and flanks brownish black and white barred. The bill is greenish yellow and the legs are dark green. The bird is about eight and a half inches long. He is usually seen 


\section{KNOWING BIRDS THROUGH STORIES}

running rapidly with the tail erect, and is most easily found in the early morning or late in the evening. He is discoverable over most of our country, migrating in the fall, but returning with the approach of warm weather in the spring. They nest mostly in the north country. 


\section{XIV.}

\section{THE AMERICAN COOT}

FTER the ducks had long stopped nesting along Awymore's Branch, another bird remained that we children were taught to call the fish duck. This bird was also known as the mud hen, I presume because it was usually found paddling around in the mud at the edge of the streams or near the shores of ponds; or it may have been because we occasionally found its nest among the rabbit ears or cat-tails where the water had dried up, leaving mud so deep that we youngsters had to roll our pants' legs above our knees to get to the nest. They were noisy birds, keeping up a clamor day and night. The note was a sort of a "Coo-coo-coo-coo-coo-coo." The first note always began on a high key and while the rest were lower it seemed as if the bird was in a great hurry to get through with his song. I used to say that if I were a bird and could sing no better than that I would want to get through with it, too, but that it seemed to me I would keep still in the first place.

The last of these birds I ever saw on Wymore's Branch were in the little pool where I became acquainted with the shitepoke. I was trudging through the woods with a twenty-two caliber rifle under the impression that I was hunting. When on such expeditions I occasionally car- 
ried home a nice bunch of game, but more often I came home without having fired a shot. I had learned to be expert in shooting, but never could make up my mind to kill anything if I allowed myself to stop and watch it for a time, because it always seemed to be having such a fine time living that it would be entirely too bad to end so happy an existence.

I had set my gun down against a tree and was watching an old mother crawfish which I had forced to release the youngsters she was carrying under her tail, gather them up again, one by one, when I heard a "quack, quack, quack," as plain as if it had been made by a duck. I had never killed any ducks and it seemed a very desirable thing to slip up on the drove which I felt sure was just around the bend of the creek and perchance shoot one.

Taking my rifle I slipped along the path that led just above the old fern bank, and when I came near crawled as noiselessly as possible to the creek bank beyond the bend. There was plenty of hazelbrush on this bank and as people were not accustomed to hunt here I found no difficulty in reaching the bank of the creek only a few yards from where $I$ expected to find my ducks without being discovered. Cautiously peering up and down the creek I saw nothing. Then it occurred to me to look in the pool and surely enough, no more than fifty or sixty feet away were a pair of fish ducks or, as they should be called, coots. They were swimming about without the least suspicion of fear, having just the best time possible catching tadpoles. No fish had been left in this pool the last time the creek had flooded, and an old warted toad had selected this place to lay her eggs and consequently there were young toad tadpoles here by the hundreds if not thou- 
sands. More than this, two or three meadow frogs had elected to lay their eggs there also and their tadpoles were abundant.

It did not take me long to recognize that these were not ducks, or at least were not the kind of ducks that I desired to kill. One very noticeable feature was that their bills were almost white and showed very conspicuously against the glossy black head and neck. In general the birds were a dark bluish color, the wings tipped and touched with white. The bill was not so broad as the bill of a duck and evidently was better suited for catching living creatures than for eating grass.

In fishing they were very active indeed. Instead of standing on their heads with their tails and heels in the air like a duck they made short quick dives, often only putting the head and neck under the water but sometimes submerging entirely. I watched them for some time, forgetting all about shooting. Finally becoming more interested I attempted to move to a new location where I could see better, when they discovered me and flew away, striking the water with a tremendous splatter of wings and feet as they rose into the air. Doubtless this was with the deliberate intention of startling me, just as a quail or a dove flaps her wings over her back for this purpose.

In Northern Iowa and Minnesota I have become better acquainted with these birds. Here they nest by the hundreds or even thousands. At one time I am sure that I saw several thousands of these birds on the shore of a lake where they appeared as thick as the chickens in our poultry yard at home. Usually they build their nests by piling reeds, moss, grass, etc., in the shallow water, anchoring them to rushes very much as does the loon. This nest 
is so constructed that should the water rise it will float higher but will not leave its moorings, but should the water dry up it will settle softly on the bottom. Sometimes where the water has gone down these nests are found several yards from the shore, but as they usually build farther out from shore than most marsh-nesting birds this is not apt to happen.

The nest is about a foot in diameter and is just saucer shaped enough on top to hold the eggs, this saucer being lined with fine grass. They lay from nine to fourteen eggs, slightly tinted with brown and minutely speckled all over with black or dark brown. They are so near the color of the nest in which they lie that it is hard to see them at a distance of a few yards.

This bird does not brood her eggs closely as do many birds. If one approaches where she is brooding she scrambles off the nest, runs a few yards and then rises into the air with a tremendous splatter and often manages to appear so badly injured as to lead people on a merry chase until she has led them far away from the nest.

Coots have a peculiar appearance when on the wing, as they often fly with the bill pointing down and the feet sticking backward and upward. The wings are much broader than tl . wings of a duck, which is a distinguishing mark between the two. When the coot alights in the water it makes a splash and when it starts to fly it makes a splatter. In fact, because of this habit, in many places it is known as the splatterer.

These birds are to be found along the creeks and in the marshes over the northern part of the United States almost from the Atlantic to the Pacific. They migrate late 

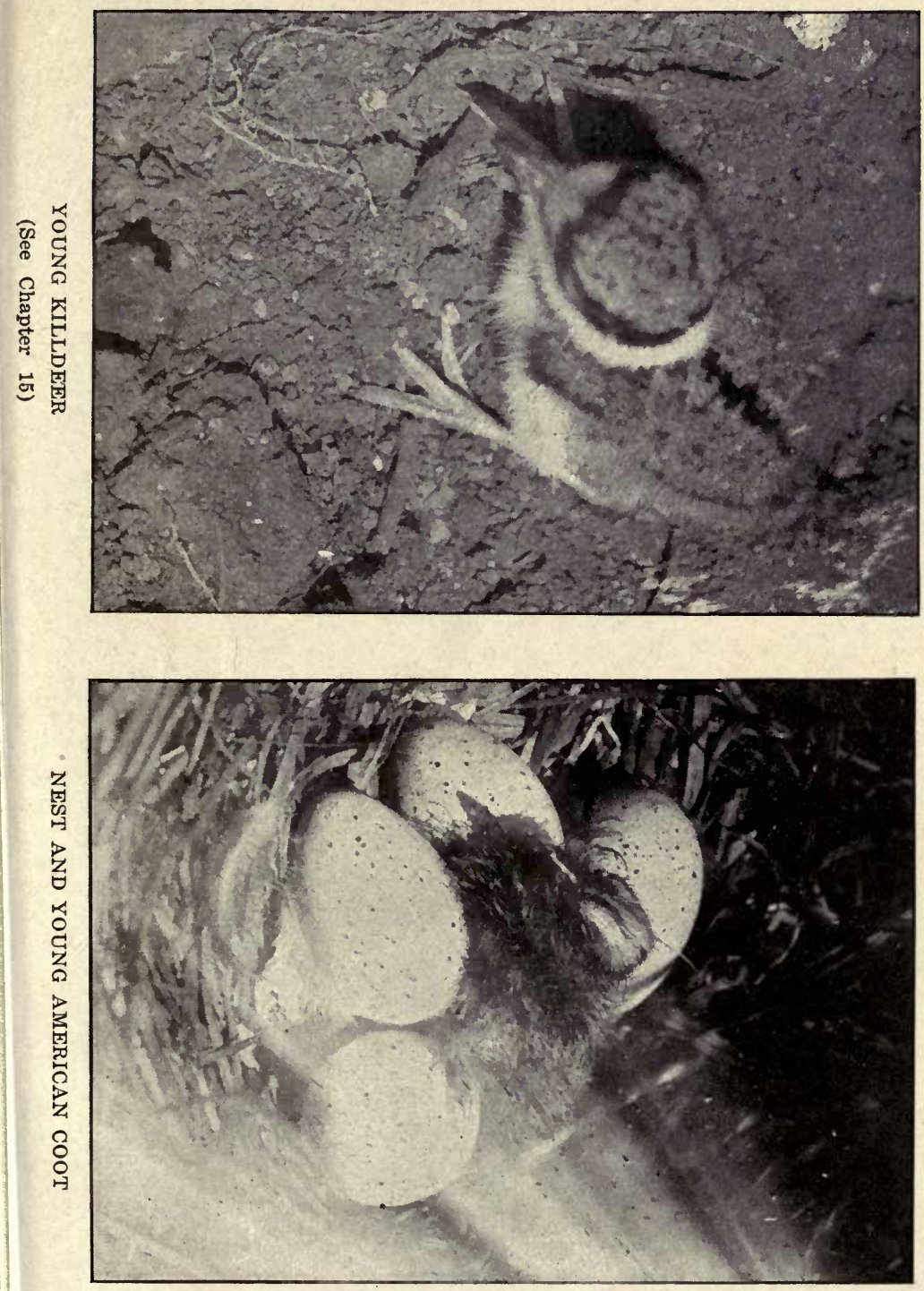


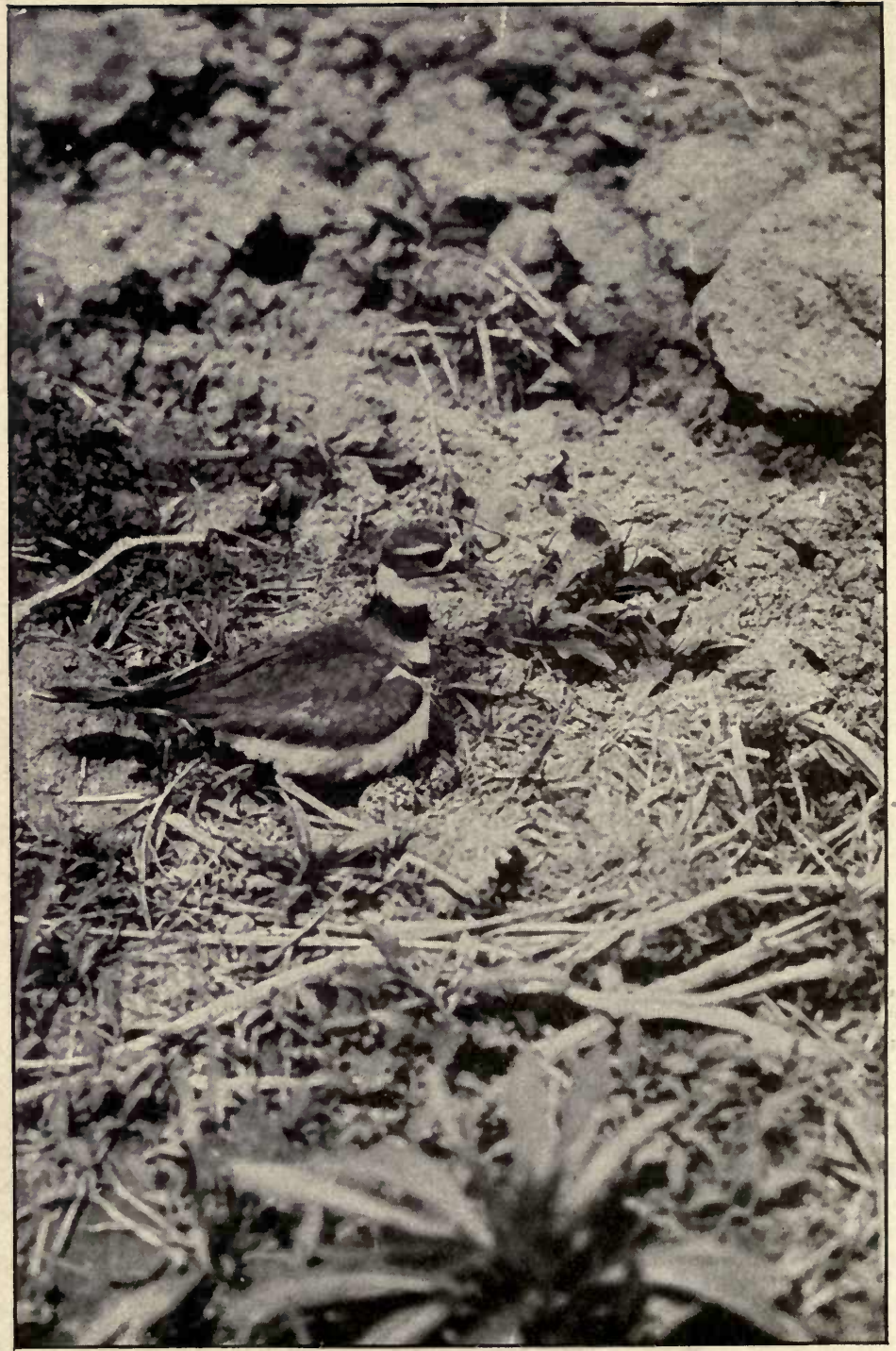

KILLDEER AND NEST

Photo by A. H. Eastgate 
in the fall and return early in the spring. They are usually found nesting in the marshes along our streams, lakes, and other similar places.

\section{Key to the Families of Paludicolæ}

\section{Megalornithide-Cranes.}

With the hind toe small and much elerated.

RALItDE-Rails, Coots, and Gallinules.

With the hind toe long and nearly on a level with the other toes, the tail feathers soft, very short, and almost bidden.

ARAMTDX-Limpkins.

With the hind toe long and nearly on a level with the other toes, but with the tail feathers stiffish and well developed.

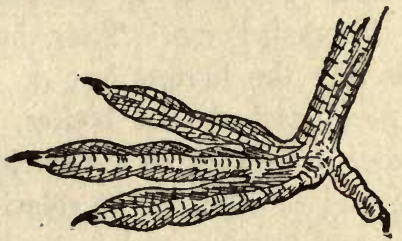

Foot of Coot 


\section{$\mathbf{X V}$}

\section{THE KILLDEER}

7 HERE is a large group of medium-sized birds that 1 have always interested me. They have long, slender legs and bills like the herons but do not have their excessively long necks and slender bodies. In fact, most of them have bodies as plump as a partridge or a quail. Their wings, long and slender, are so relatively more than those of the crane and herons; and instead of being awkward on their legs these birds are rapid runners. Indeed, I know of no birds anywhere near their size that are so active on foot as this family. There are many varieties, commonly known as snipes, sandpipers, woodcocks, plovers, etc. They all have similar habits, so if you know the life history of one, you can form a fair idea of how the others live. They are easily recognized from other birds by their long legs and distinctive bills, which separate them from other birds in general, and by the plump body and shorter neck which distinguish them from the cranes, the herons, and the bitterns.

These birds for the most part live along the coast or along the shores of lakes and streams, tho they are often found in pastures and meadows, especially in the swampy places. They feed mostly on worms, snails, insects and crustaceans that are found in shallow water. Possibly 
the most common and the best known of these birds is the killdeer. I have known these birds practically all my life, and have never been in any part of the United States where they are not found, altho of course they are much more abundant in some places than in others. But it has been only within the last ten or fifteen years that I have had the opportunity to know them intimately. From my class room I can look out over a pasture and see from one to two dozen killdeers almost any time. There is a small draw that heads in this pasture that or a large part of the year is more or less swampy. If I start across this part of the pasture, these birds from all sides begin screaming "killdeer, killdeer," and I see them running ahead of me very much as quails often do; but they do not run far before taking flight. For seventeen years no one has been allowed to shoot them. Probably no birds living there now have ever been shot at. For this reason they are tame, and even when they fly do not go more than a few rods before alighting.

In spite of my busy life I have had opportunity to watch these birds carefully. I find that they are experts in locating cut-worms or angleworms even tho these are buried under the soil, and that they are equally expert in digging down to them with their long, sharp bills. Their food consists largely of these worms, caterpillars, grasshoppers and other insects. If other foods run short, they feed on the young succulent grass that is sure to be found in swampy places. They particularly like to run over the garden in the springtime. When the garden is being plowed they make it a point to run over the newly plowed ground in search of angleworms or moth chrysalids that may be turned out. As the early vegetables 
come on, these birds are often seen running up and down the rows of cabbage and lettuce, picking off the worms. They are jolly little fellows, always chuckling to themselves, especially when they find a worm.

They usually live and feed in small flocks, and there is always a sentry or two on guard while the others feed. When disturbed this sentry warns his fellows by a sharp, piercing cry and then flies to safety.

Every season for at least ten years I have found one or more killdeer's nests in the garden. I was especially amused with one killdeer's nest I found about the tenth of last June. She had wallowed a little hole in the gravel on a side hill in a field of newly set strawberries. I was looking over this field in company with a friend, when to my amusement a killdeer ran up almost to our very feet and fell over and begun to flutter as if she had heart failure and was in her death throes. I was far too wise in bird lore to allow her to fool me into trying to catch her or into following her, and this seemed to worry her a great deal. Over and over she would flutter away fifteen or twenty feet, making it very plain that she was in the greatest pain, that one wing was broken and that the leg on the other side couldn't be used at all. She would struggle over the ground with one wing and one leg dragging, uttering the most pitiful cries of pain and distress, but when we refused to follow, she always managed to be able to fly back and fall almost at our feet again. I had not seen the nest as yet, and but for her antics doubtless we never would have seen or known that it was there; but by circling about a bit and watching her actions it was easy to see when I was getting farther away or nearer to the nest, and before many minutes $I$ found it. 
A killdeer's nest is not the casiest thirg to sed its simply a shallow depression wallowea into the "ground, and may or may not be lined with a few straws. This nest had no lining. The eggs were thickly speckled and so closely matched the pebbles in the soil that, even when I saw the nest, it was hard to distinguish the eggs at a distance of ten feet. We walked up within three or four feet of the nest; but as we did not touch the eggs and finally went away, I am quite sure that the mother believed that we did not find it. This bird laid four eggs and sat on them for days; then one morning about nine o'clock she came off the nest and lo, four little fuzzy, blackish brown and white mottled balls of down begun to run over the ground after her. I never see young killdeers but their small bodies and long legs make me think of the toy animals I used to make when a child by sticking sticks into small potatoes or match straws into peanut shells.

While these little creatures are colored so nearly like the ground, they are more easily seen than young quails of similar age. They do not stay in the nest like most birds, nor do they always follow the mother closely like the young quail, tho they are often with her. They often straggle across the field as they will, usually keeping near the nesting place. When the mother bird comes to find them she utters her call, alights on the ground and starts running about, chattering, while they come running for whatever she may have. These little fellows do not seem to be in the least afraid of man. I do not know whether it is because they have not been disturbed for so many years, for I never was fortunate enough to see young killdeers until the past few years, but I have never seen any that tried very hard to get away when I wished to catch them 


\section{KNOWING BIRDS THROUGH STORIES}

and-I thave even kacwn them to run to me-whether for protection or "because they thought I might have something to feed them I never could quite make out. They grow rapidly and when three weeks old, if all has gone well, are able to fly, but long before this time they have become fast runners. It has always been a mystery to me how these little fellows escape their enemies. I can understand well enough that their protective coloring saves them from hawks and owls, but there are rats, snakes, ground squirrels, and dozens of other small animals at large, and anything as innocent as a little killdeer wandering over the earth must meet these creatures frequently. That they usually get by alive is proved by the ever increasing numbers that are seen in the pasture near by.

I have stated that I have never seen the young killdeers follow their mother as young quails follow theirs. Others, however, have told me that they have seen the mother killdeer running about on the ground with her young folv lowing her closely. The mother bird does not carry worms to her young, but helps them to find their food on the ground. In order to do this she must be with them a great part of the time. I presume the reason I find them alone so often is that the mother bird is on the wing so much of the time that the little birds become scattered while she is away. When they have the opportunity, they doubtless follow her as other birds do. When night comes the mother killdeer comes back to the vicinity of the nest, calls her babies together, and hovers them during the night.

The killdeer is not a bird that minds the cold weather as long as it can get plenty of food. In open winters they used to stay all the year round in Iowa, but commonly 
they disappeared about the time the first heary snows fell, but were sure to be back again with the return of spring. Near Nashville, Tennessee, where I am now living, they are with us all the time except in the stormiest and snowiest weather. Doubtless, like most of our other birds, they retire to the cane brakes and thick brush when such weather comes.

Many people hunt the killdeer for food. This is true also of most snipes. The woodcock, one of the snipe family that is found over much of our country, is even a greater delicacy than quail. It seems too bad that such beautiful and valuable creatures as our birds must be slaughtered by tens of thousands every year simply that man may satisfy his appetite. Having protected the birds for the past eighteen years, our school farm has become a veritable bird haven, and probably this accounts for the fact that we have killdeers in such great numbers.

\section{Key to the Families of Limicolæ}

JACANIDE-Jacanas.

With the claw of the hind toe longer than the toe alone.

Phalaropodide-Phalatopes.

With the claw of the hind toe not longer than the toe alone, and the toes with lateral, usually scalloped membranes.

APHRIZIDE-Surf-birds and Turnstones.

With the tarsus transversely scaled in front, the toes without lateral membranes, bill stout and not longer than the middle toe without claw.

Scolopacide-Snipes and Sandpipers.

Similar to APHRIZID , but bill slender and longer than the middle toe without claw.

RECURVirostride-Avocets.

Tarsus covered in front with irregular or hexagonal scales and more than twice as long as the middle toe with claw.

HAMATOPODIDE-Oyster-catchers.

Tarsus covered in front with irregular or hexagonal scales, but less than twice as long as the middle toe with claw; and the bill longer than the tarsus, wedge-shaped at the tip.

Charadritde-Plovers.

Like HEMATOPODID $x$, but bill shorter than tarsus and not wedgeshaped at tip (the tarsus in one species transversely scaled in front). 


\section{XVI}

\section{LADY BETTY'S HUSBAND.}

ROB was the husband of Lady Betty, our tame quail. $B \mathrm{He}$ was born in a snug, grassy nest at the edge of the meadow beyond the orchard. His mother with the wisdom of her race had so timed the laying of her eggs that Bob and his fourteen brothers and sisters were hatched just three days after longhorns, the grasshopper, and his nestmates crawled out of the grass and weeds at the further edge of the meadow. Within less than twenty minutes of the time Bob was hatched, he was attempting to follow his mother through the wilderness that man called a meadow. His fellows had all popped out of their shells within a few moments of the time that Bob crept out of his. One of the marvellous things about the wildlings who lead their young from the nest in search of food is that many of them often hatch all their eggs at almost the same moment.

When quail eggs were hatched under the old bantam hen, they often required several hours to get out of the shell. Bob and his fellows were hatched in the morning and left the nest as soon as the dew had dried off the grass. The ever watchful mother, knowing where the grasshoppers were emerging by the thousands, led her brood to the edge of the cornfield where each little fledgling tried to excel the other in catching baby grasshoppers. 
One reason why quail are so valuable is that the first brood usually hatches within a few days after the grasshoppers emerge from their nests, and the baby quails eat them by the thousands. After half an hour or so, when the babies had all dined, the mother hovered beside a clod so nearly her own color that no sparrow hawk which might chance to fly overhead could notice her, and the babies snuggled under her or sprawled about her in the sunshine for a nap.

Toward evening, after the babies had fed and slept by turns throughout the day, the mother led her family back to sleep, perhaps for the last time in the home nest. Had it been necessary to wander far in search of food, she would not have returned to the nest for even the first night. The second evening this mother merely crept under the hedge and settled for the night on some dry leaves. Within a week she ceased to hover her brood, and instead they all sat beside her until morning.

By the time Bob was twenty-four hours old his father joined the family and bore his full share of the family responsibilities. When Bob was about two weeks old he was surprized to have his faithful little mother disappear for two or three hours one day. His father became even more watchful and solicitous for the safety of the family. When the mother returned, however, the children were all delighted to see her. The next day she disappeared again and this became the daily program for nearly two weeks. Probably Bob did not know that his sweet little mother had made another nest and was stealing away every day to add an egg to the growing treasure that was soon to be hatched into another brood of baby quails.

Before Bob was a month old he could fly as well as any bird, though he was not yet nearly grown up. His 
mother had deserted the family save for a short time occasionally, but the father never led them far from the new nest and every night they roosted close by the mother and her treasures.

The second family had their first feed on the chinch bugs that were just now running from the wheat into the corn. The mother would gather her family around a cornstalk on which there were dozens of chinch bugs, then backing off a few feet, she would fly against this cornstalk with sufficient force to jar the bugs to the ground. Before they could take flight or crawl back on the stalk the baby quails had fed in abundance. Thus the wild mother showed her wisdom again. Had these babies hatched a few days sooner, the chinch bugs would have been in the wheat field and therefore difficult to secure. Within a week the parents had united their flocks. Again it was only a few days till the mother was slipping away every day, leaving to her husband the entire responsibility of both broods. When the third brood was ten days old again the family united, and ran together until all were mature.

As spring drew nigh, the flock scattered in all directions, possibly a provision of nature against close inbreeding. But Bob chanced to return to the old home.

Quails were whistling their "Bob-white" on every bright morning and the spirit of spring was everywhere. Bob whistled his loudest and best, stopping to listen each time for an answering call from the mate he hoped to find. One day the boy took it into his head to whistle "Bob-white" in reply, so every time Bob whistled he received an answering call from the dooryard. Fearing lest his fancied rival might be more successful in finding the mate he felt 
sure was near, each time the boy whistled, Bob flew a little nearer until finally he alighted on the garden fence within fifty feet of the dooryard. Lady Betty, the pet quail that nested in grandfather's old carpet slippers, had been growing uneasy with the return of spring, and while she ordinarily was perfectly contented with her human companions, now she often wandered about the yard and orchard whistling her sweet little call, so different from that of the male. Most pet birds seem to feel above others of their kind, but Betty was such an adorable, unassuming little lady that it never entered her small head that she was superior to any one. So when the Bobwhite, dressed in his best summer suit, lighted on the garden fence and began whistling his love song, she was charmed at once. She did not immediately answer, however, but quietly flew around the house and into the edge of the orchard where it was almost impossible that she should not be seen. Bob flew directly to her and began fluttering and strutting about making the greatest possible ado over her. Betty had been reared with human folk and knew little of the doings of her own race. Perhaps she was not as coquettish as she might have been had she grown up with a flock of birds and been used to the flattery of such young gentlemen. As it was, within ten minutes the matter was settled. I never have known a bird wooing that was accomplished in such a simple manner or within such a short time, either before or since, but undoubtedly it was just as satisfactory as if it had taken a month. Together they wandered through the orchard the remainder of the day as happy as two birds could be. Poor Bob, little did he realize that henceforth he was to be known simply as Lady Betty's husband and to be worried and harassed 


\section{KNOWING BIRDS THROUGH STORIES}

by her doings which he never could understand or approve. Toward evening Betty insisted on coming into the dooryard, and poor Bob was distressed beyond measure. Every instinct and every bit of training he had ever received told him she was going to certain death and she seemed wholly unconscious of the fact. When mother threw out a handful of feed, poor Bob flew to the orchard, but true to the habits of his race, no sooner had he alighted than he ran back, keeping well under cover, to see what happened to Betty. When finally he peeped through the garden fence and saw her contentedly sitting on mother's shoulder, his surprize was beyond description. He began fluttering and flopping much as a mother dove would have done had some one disturbed her nest, and when he had attracted Betty's attention, he rose with a tremendous whirr and flew toward the meadow. Betty paid not the least attention and when night came roosted on the porch as usual.

Day after day Bob fussed and fretted in his endeavors to persuade Betty that she was not safe, but when at last she made her nest in the house he overcame his fears suffciently to sit on the railing of the porch, provided no one came near. When the little quails were hatched and Betty led them proudly into the front yard he alighted by her side with every demonstration of joy, but when mother threw a finely minced hard-boiled egg to the brood, he rose with a whirr which frightened the poor little fellows almost out of their wits. It was interesting to see how those babes, which but an hour ago had hatched, at this first call of danger scattered like the leaves of autumn, each hiding in the best manner possible. Betty began calling in her gentle soothing voice and presently one little fellow after 


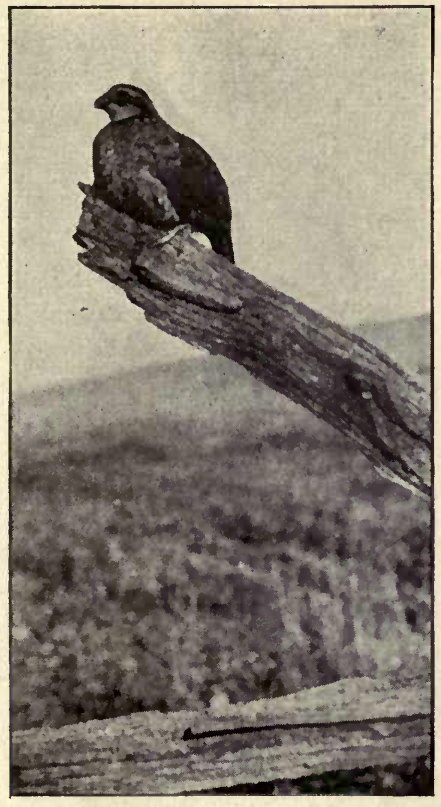

MALE BOBWHITE

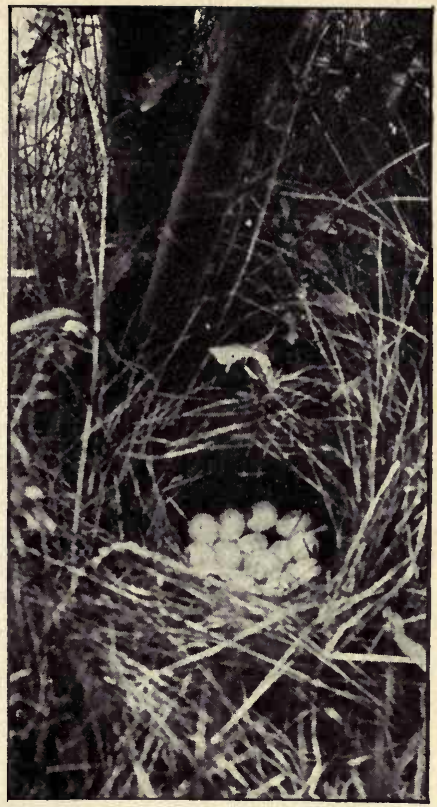

BOBWHITE'S NEST

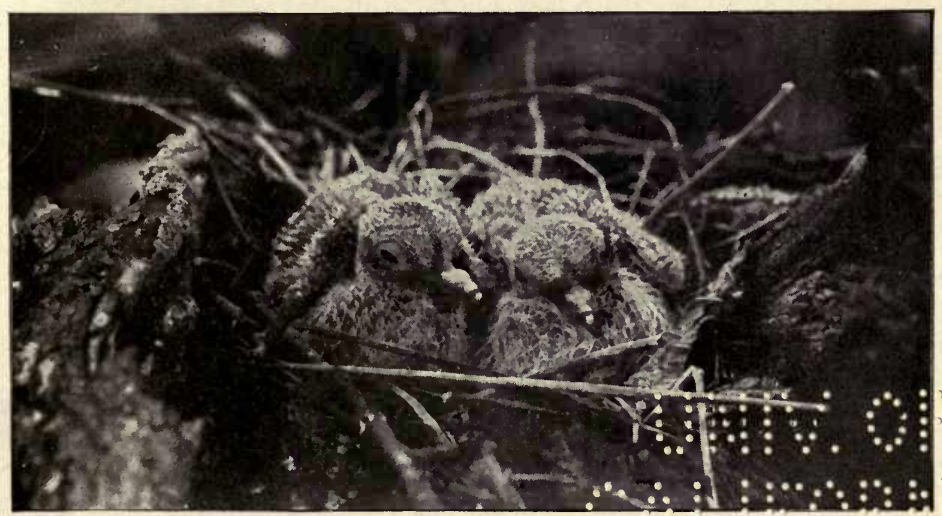



another slipped out of the grass, peered around cautiously, and then ran to their mother and began feeding on the egg. Within a week the brood was perfectly tame, but poor Bob never could satisfy himself that his family was not being wrongly educated. When Lady Betty began sitting on the second clutch of eggs, he led the brood to the orchard and vineyard and before many days they began to be shy. When winter came they followed Bob to the fields and left Betty to enjoy the luxuries of her home alone.

However, when winter piled snow several feet deep, instead of plunging under the snow after the manner of quail and prairie chickens, and huddling together to keep warm for the night, thus taking a chance of being imprisoned by the terrible crust that so often forms over the surface, Bob was wise enough to lead his brood to feed at the corn crib and to roost under the cattle shed.

Toward spring Bob and his flock disappeared. Whether he was killed or whether he chose to leave the vicinity and choose another mate I can not say. For years a flock of quails nested in our orchard and meadow, and were so gentle that they would scarcely fly when discovered and did not hesitate to come to the barnlot and the corn crib for food whenever it was scarce in the fields.

We have several varieties of the bobwhite quail in America, differing mostly in size and color, but the differences are so slight that any person who is acquainted with one would recognize the others as of the same family.

We have several flocks of quail where I am now located. These have been carefully protected for years, and almost every summer there are nests within a hundred yards of my house. In the summer of 1922, a quail nested near 


\section{KNOWING BIRDS THROUGH STORIES}

by that was so fearless that she would allow those whom she saw working about her every day to come within eight or ten feet without showing the least fear, and one day one of our faculty put his hand over her and stroked her while she was on the nest, and even then she did not fly.

Quails feed largely on weed seeds and insects, altho, of course, at certain times of the year they eat grain. However, very little of the grain the quails eat would ever be of value to man, for it is the waste grain that is scattered over the fields and would never be gathered.

Truly the Bobwhite deserves his name, "the farmer's friend," for no bird that lives is more beneficial, more cheery, and more worth encouraging than he. 


\section{XVII}

\section{THE PRAIRIE CHICKEN}

TST below our garden was a fire acre meadow which sloped gently south and southwest. It was protected on the north and northwest by our buildings and the grove beyond, and naturally in the winter the snow melted off there when it was still abundant in most places. It was a fertile meadow containing about an even mixture of clover and timothy and remained green through the winter. While the same thing doubtless occurred at times every winter, I especially remember the winter I was eight years old that some spots in this meadow were bare nearly all of the time, though there was much snow over the country in general. This became a favorite feeding place for many birds. In fact, it was the one spot that kept hundreds of birds from going hungry or perhaps from starving that winter. While other birds came to this meadow by twos and threes at various times in the day, along about ten o'clock in the morning, prairie chickens usually began to arrive in flocks of from a dozen to several hundred. Often one could count as many as five or six hundred prairie chickens feeding there.

As many of my readers have never seen prairie chickens, I wish to say that this bird is a scratcher. It belongs to the grouse branch of the family and in size is about as 
large as a guinea fowl. In the early history of our country prairie chickens bred by the millions in parts of Illinois, Iowa, Nebraska, Kansas, and the country bordering on those States. Like most of their family they do not fear the cold and, except on the plains, seldom migrate more than a few miles, if at all. They used to gather in our meadow and spend hours running about eating grass and picking up such hibernating worms or grubs as they were able to scratch out of the frozen ground. They were an interesting lot of birds, and were so cheery and happy that we would not shoot them ourselves, and did not permit anyone else to do so.

Our garden was surrounded by an Osage Orange hedge that had been trimmed carefully and was so thick that one could scarcely see through it. It was an easy thing to slip along under cover of this hedge and get within fifty or seventy-five yards of the prairie chickens to watch them at their feeding. They were sociable birds, always good natured. Never once at such seasons did I see fighting or quarreling in the flock.

In those days we as well as practically all our neighbors ate prairie chicken, but we did not care to shoot them because we did not wish to frighten them away. We recognized that most of them had been reared on the prairie forty or fifty miles away, and had gathered in our part of the country in the winter only because they could there secure more food and protection. But we could not help hoping that some of them would remain behind and nest on our place, especially if we did not disturb them overmuch.

In the early morning and late evening those prairie chickens would fly to the various cornfields in the neigh- 
borhood and, alighting on the corn shocks, scratch into the ears and help themselves to the corn. I presume they must have eaten a considerable amount of corn, but corn was cheap and every one had plenty, and I do not think it was missed much.

We used to make traps of lath, building them four square, a little wider at the bottom than at the top, making them about two and a half or three feet high. At the bottom these traps were as large each way as a common lath is long. The top consisted of a trap door made of lath and so hung that if a bird lighted on one half of it, it would trip at once and let the bird slide down into the trap while a weight on the other half of the top immediately closed this trap door. Pieces of lath were nailed every few inches around the edge of the trap and were sharpened at the top so that ears of corn could be stuck on them. A little corn was shelled and thrown inside and a few grains scattered around the outside. On cold icy days when it was difficult to scratch their way into the corn in the shock this was very tempting to the prairie chicken. They would first eat the corn scattered on the snow and then hop up on the trap expecting to pick the corn off of the ears that were stuck on the edge. Of course they could not alight on the edge of the trap as the ears were too close together, and since the top looked perfectly secure they alighted there and fell through the trap door. Sometimes we would catch as many as a dozen or more in a single trap in one day. This method of catching them had at least the advantages of not frightening the others and of not crippling any that were not killed.

As the broad prairies began to be settled and the tall grass plowed under, prairie chickens lost their best breed- 


\section{KNOWING BIRDS THROUGH STORIES}

ing grounds and soon began to grow scarce. Now where we used to see thousands every day it is the exception if we see a dozen in a year's time. It seems too bad that the progress of man should always work the extermination of the best of our wildlings.

But to return to my story. As the winter wore away and the snow melted off the prairie chickens began to depart for their nesting grounds, but as we had hoped, all did not go. Both on our farm and that of our next neighbor there were wet places where the slough grass had grown five or six feet tall. This grass did not make good hay, neither did it afford first class pasture. As long as we had plenty of blue grass pasture for the cattle and of timothy and clover for hay this grass was seldom disturbed except to cut enough of it to top out other stacks. It did not take the prairie chickens long to locate these places.

With the first bright spring mornings, even before the snow drifts were all gone, I used to be awakened at daybreak by the crowing or rather booming of the prairie cocks as they strutted about over the meadows and made love to the hens. In the springtime the cock becomes as proud and quarrelsome as a turkey gobbler. He struts about in the early morning uttering a half crow, half boom, heavy and loud out of all proportion to the size of the bird. On a crisp frosty spring morning this can be heard for two or three miles. I used to like to slip around the fields and watch these birds strutting and crowing about among the hens, attempting to win them. At such times the cocks are apt to clash frequently and fight like demons.

By the middle of April we used to find nests on the 
ground in this tall slough grass. These nests were depressions scratched in the ground, but there was always enough grass and leaves scratched together so that the eggs were well protected. The eggs were almost identical with guinea fowl eggs in both size and shape, and it was not uncommon to find as many as fifteen in a nest. Not realizing how much mischief we were doing, we boys used to hunt these nests and take the eggs home and boil them. In flavor they tasted very much like a guinea's egg, tho if anything they were of even better quality. I was in Eastern Nebraska one spring when a prairie fire swept over the country. Undoubtedly there were few old birds killed by this fire and the young had not yet hatched, but one could walk over the black and charred ground, especially in the low places where the tall grass had been abundant, and find eggs literally by the hundreds. We gathered all of these we could use. Some were roasted, some were merely scorched, and some seemingly were not injured at all.

As prairie chickens grew scarce at home we began to follow the practise of leaving the grass for the prairie chickens' special use in one little slough that ran through a field which we usually planted to corn. There it was that I got my first idea of the injury crows do other birds. We were plowing, Brother John and I, on the same land, one team following the other, when an old black crow alighted on a tall fence stake at the edge of this slough. Presently he hopped off on the ground and we noticed a strange sight. He would peck at something and flutter and flap his wings and then jump back. Presently we saw an old prairie hen attempting to drive this black rascal away from this piece of ground. She would peck and scratch and pound with her wings equal to any old setting hen, 


\section{KNOWING BIRDS THROUGH STORIES}

but the crow usually managed to keep out of her reach. Finally he half jumped and half flew over her head, made a grab at something, then flew back upon the stake and we could see clearly that he had an egg in his mouth. Now the secret was out. He had found this prairie hen's nest and she was defending her eggs. Knowing that it was useless to interfere in a case of this kind we went on with our plowing and watched these birds as much as possible. The trouble continued for an hour or more and we knew that the crow got another egg. Finally, perhaps because his hunger was satisfied for the time or possibly because he had received more punishment from the prairie hen than he wished he left the place.

We had noticed that he alighted on an unusually tall fence stake before attempting to reach the nest and perched there while eating the eggs that he succeeded in stealing. When we went to dinner, Brother John, who was an expert at trapping hawks and owls, brought a steel trap back to the field with him and set it on the top of this stake, driving the ferrule of the chain into the hard wood of the stake. About the middle of the afternoon this old black crow alighted on the ground near this nest. After trudging about for a time he managed to get another egg before the mother discovered him. One egg was all that he secured before she rushed to the defense of her nest. Realizing that he would be safe from attack while perched on top of this stake the crow alighted on it without stopping to look. Crows very seldom alight anywhere without very carefully scrutinizing the place, but like most people who are engaged in rascality he lost his good judgment for once, and once was all that was necessary. The trap caught him by both legs and held him securely. We 


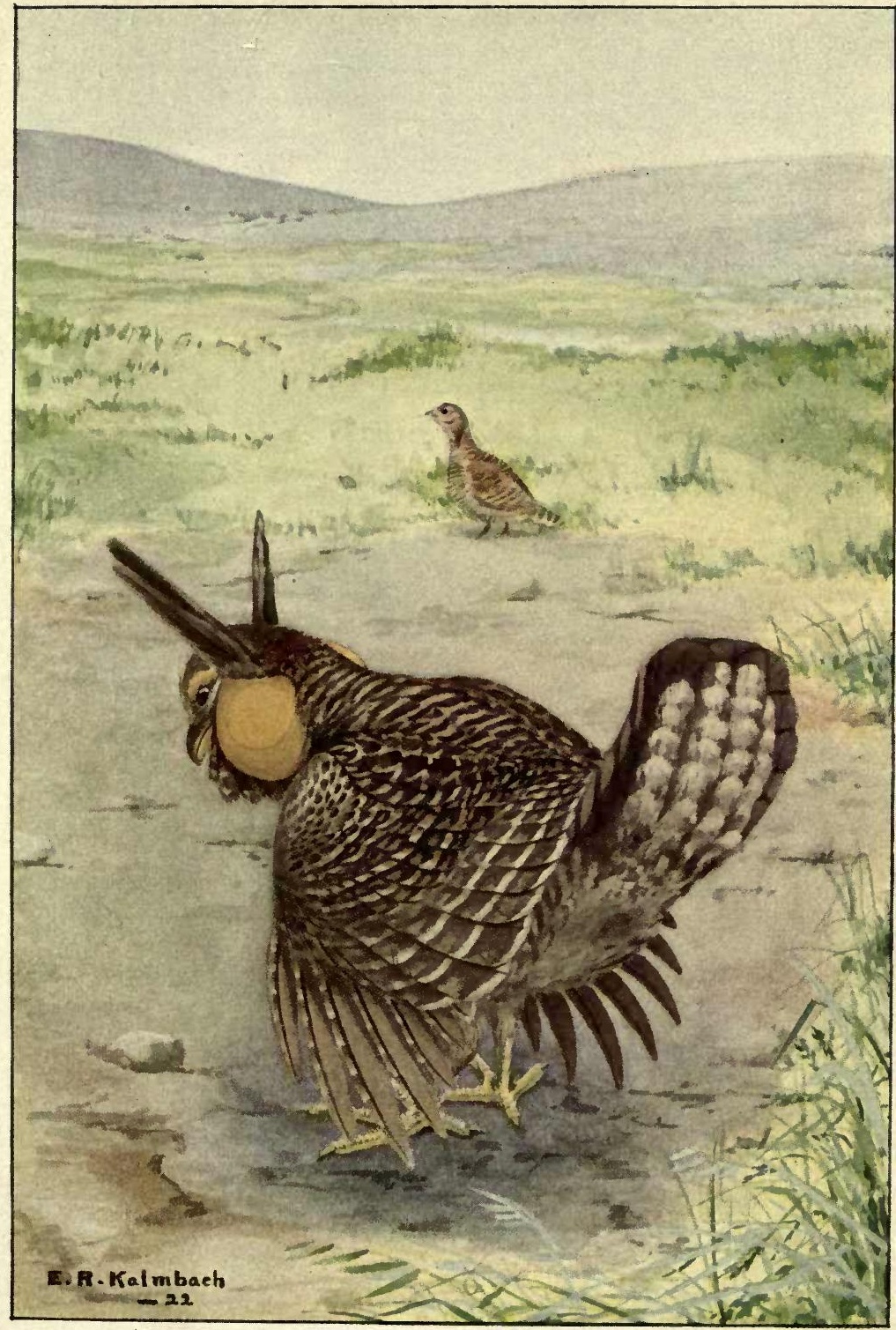

PRAIRIE CHICKENS

Male in Foreground-Strutting 

left our teams and ran to him in triumph, beat his head over the stake and hung his carcass from its top, and from that time our prairie chicken's nest was secure from molestation.

Examination showed that there were still six eggs unbroken and that the bird had not begun to sit. We knew better than to touch the prairie chicken's eggs or to get too near the nest, for we did not want the mother to desert it. So we contented ourselves with marking the place so that we could easily find it again. The mother, now that her tormentor was gone, laid several more eggs and hatched the last brood of prairie chickens I ever knew to be raised on our farm.

Little prairie chickens look very much like little quail, except that they are larger. Any one who is familiar with newly hatched guinea fowls knows about what a little prairie chicken looks like, for, I believe, if one should mix the eggs of the two birds together, when they hatched he would have difficulty distinguishing the young birds from each other until they were perhaps a week old and the wing and tail feathers started to grow.

Like young quails they have the faculty of hiding anywhere, anytime, should danger come. The mother could be leading the young birds through the grass, all of them as busy as could be, catching young grasshoppers and small bugs, but let me show my head and away she would go with a whir that would startle any one and not a young bird was to be seen. I have spent half an hour looking for the young birds when I knew at least a dozen were concealed within ten or twelve feet of me and still would not be able to find one. After becoming more familiar with them I found that they not only squatted flat on the ground 
where their peculiar stripes of various shades of brown blended perfectly with the grass and earth, but should I get too near and they saw my eye was not on them they did not hesitate to run six or eight feet like a streak and then again squat on the ground and hide. I used to be almost afraid to walk about lest I step on some little fellows that might be hiding under my feet, but I never had this misfortune, probably because they were shrewd enough to slip out of the way of my foot if it got too near.

By the time they were two weeks old their wing and tail feathers had grown amazingly and they were beginning to fly. At three weeks, while not nearly half grown, they could fly as well as their mother, and if anything disturbed them they usually flew away in a flock.

Prairie chickens are now scarce in almost every part of the country. Perhaps they are most numerous in the Dakotas, Nebraska, and Northwestern Texas at present. They are larger than the New England partridge or pheasant, but not so large as the Western sage hen. In fact, they are about the size of some of the grouse that are found in the Rocky Mountain districts. All of these birds belong to the same family, and have the same general character. All have been favorite gams birds, and under the relentless hand of man are growing scarcer.

Seemingly no one has successfully domesticated the prairie chicken, but they certainly are no wilder and should be no harder to domesticate than the guinea of South Africa; and this fowl has within the last few hundred years become almost as well domesticated as the common chicken. I am sure the prairie chicken is superior in almost every way to the guinea fowl, and it is unfortunate 


\section{THE PRAIRIE CHICKEN}

that no one has made a success of domesticating this valuable bird.

\section{Key to the Families of Gallinæ}

\section{CRACIDE-Curassows and Guans.}

With the hind toe inserted on the level of the anterior toes, and more than half as long as the lateral toe.

MELEAGRIDIDE-Turkeys.

Large, long-necked birds, with the hind toe less than half as long as the lateral, and inserted above the level of the rest; legs with spurs, and entire bead unfeathered.

ODONTOPHORIDA-American Quails.

Small or moderate-sized, rather short-necked birds, without spurs, and with the head feathered; tarsus and nostrils entirely unfeathered.

TrTRaONiDA-Grouse.

Moderate or rather large sized birds with the tarsus at least partly feathered, and the nostrils wholly so. 


\section{XVIII}

\section{THE MOURNING DOVE}

NE of my earliest recollections is of a hired man by the name of Dan Scott who used to take a great deal of interest in me, whether for his own pleasure or for mine I am not sure, but probably for both. Every evening he would take me on his knees and tell me "ringtails" for an hour or so, and they certainly were "ringtails." He it was who soberly informed me that if I put salt on a bird's tail I could catch it. I supposed any ordinarily bright boy ought to have seen the joke, but with me it was a serious matter; and I used to spend hours slipping through the woods and along the hedge fences with both hands full of salt, fully determined to put salt on the tails of all the birds in the neighborhood so that I could catch them.

I suppose this idea of being able to catch birds appeals to all boys. My good mother always told me that in heaven the birds will be perfectly tame and that we shall not have to keep them in cages in order to have them for pets. Most of my pet birds were gentle enough to come to me in any place and at any time, though they flew in the open the same as any other bird; but the experience I am now to tell came after my dismal failure to tame birds by putting salt on their tails. 
You may think that this putting of salt on a bird's tail has nothing to do with teaching you how to know birds, but it certainly did have a great deal to do with my learning to recognize them, for I am sure that if $I$ had not been simple enough to believe that Dan Scott meant everything he said and if I had not set out to carry it into practise, I never would have met so many interesting birds, nor would I have seen so much of their family life.

I remember very well that one day I was slipping very quietly along the Osage Orange hedge that divided our pastures when suddenly a turtle dove appeared on the ground not three feet in front of me and began wallowing and fluttering as if in great terror, but wholly unable to get away. This was a wholly new procedure to me. Salt and tails alike were forgotten and I made a wild scramble to catch the crippled bird. Down I went on the ground half a dozen times, catching only a handful of grass, the poor bird having been able to get just a few inches from my hand. I was perspiring and worn out with excitement and effort when after chasing this bird back and forth for ten or fifteen minutes it suddenly rose and flew off as nimbly as could be. By this time we were on the bank of the brook where there was a little point with a steep slope on both sides. I had maneuvered to get the bird to this point because I know it would fall off the bank and then I would have a better chance to catch the poor thing. On looking around I discovered that I was more than a hundred yards from where we started the chase. I knew just where it had begun, for there lay my new straw hat, with purple straws woven in it, where $I$ had lost it at the first dive after the dove. I remember this very clearly, 


\section{KNOWING BIRDS THROUGH STORIES}

for this hat was a special treasure of mine which had been bought only two days before, and it was the first hat I had ever seen made from white straw with a purple straw woven in every inch or so.

I trudged as fast as my four-year-old legs would carry me to get my hat, but to my surprize when I went to pick it up this poor crippled dove fell almost at my feet again. I was sure this time that she was mortally hurt. I had seen birds that had been shot make a desperate effort and fly for a distance only to fall utterly exhausted at last. Clutching my hat in one hand I gave chase again but some way or another when we had gotten far enough away this dove managed to rise and fly again. This time I went home to tell mother my troubles and ask her about the bird. You may imagine my chagrin when she told me that this bird was not hurt at all, but was merely feigning in order to lead me away from her nest. She told me that if I would pay no attention to the bird but looked sharp I undoubtedly would find a nest in the hedge very close to the spot where I first found the bird.

As soon as she could get her work in condition so that she could leave, she went with me to help find the nest, for no barefooted boy would dare to get near enough to an Osage Orange hedge to look into a bird's nest. Sure enough, in the forks of an old limb that had been stuck through the hedge to fill up a hole where some cow at one time or another had broken through was a dove's nest, the first one I remember having seen. It seemed to me that it was about the poorest excuse for a bird's nest imaginable. All there was to it was a flat saucer of sticks with a few straws and weeds stuck in to form a rim. In this nest were two almost perfectly round snow white eggs. 
We had plenty of pigeons in our barn and I was familiar with pigeons' nests and eggs. I remember well that it dawned on my mind that this dove must be a pigeon, because the nest and the eggs looked so much like those of a pigeon. Mother told me that they were of the same family and that there was another member of this family that used to be very plentiful but was now growing scarce, at least in our Iowa woods. On the way home, if my memory serves me right, she showed me a flock of thirteen of these wild pigeons. That was the only flock of wild pigeons I ever remember seeing, tho I occasionally saw a pair or a single bird after that. But I shall never forget the wonderful stories father and mother used to tell me of the wild pigeons and their roosts in the Ozark regions in Missouri when they were first married. These pigeons used to pass over their house in such flocks as at times to obscure the sun. In the morning until eight or nine o'clock they would fly, flock after flock, from their roosts to the fields and meadows, and about an hour before sundown they would begin to return to the roosting place. So low did they fly and in such dense flocks that one could hardly throw a stone into the flock without bringing down a bird.

The roost was a large oak grove only a short distance from home. There the birds roosted in untold thousands alighting on the branches so thickly that they would often break them down. Father said that in the roost at night the cooing of pigeons and the flapping of the wings of birds that were coming in late made a noise so great that even the report of a gun was not noticed by the pigeons. People would go into this roost and kill them by the sackful with guns, clubs, rocks, nets, and in other ways. 
Finally, when the railroad entered that part of the country, the pigeons were slaughtered by the tens of thousands and shipped to the city markets. This pigeon is now totally extinct. It was one of our most interesting American birds and was found over the greater part of the Mississippi valley, but like the buffalo it had to go before the hunter's gun.

Doves and pigeons belong to the family Columbidæ. They are peaceable birds, and look much alike. In fact, their shape and appearance are so distinct that any one who has seen a domestic pigeon should at once recognize any member of the family even tho he does not know its variety name. All these birds are largely seed eaters. So far as I know they do not eat many insects or meat of any kind. They do eat some green vegetable matter and fruit, but mostly seeds. When the wheat and oats were in the shock, farmers often complained because the birds congregated in the grain fields and fattened themselves on the ripened grain.

The common turtle dove is one of the smaller birds of this family. It is of a beautiful pinkish drab and brownish above with a bluish gray head, and is very graceful. It is found over most of the United States. One of its characteristics is the fact that when it is startled and flies up unexpectedly it flaps its wings together with a loud report that startles you so that you are not able to do anything until it is safe out of your way. Yet if this bird sees you approach it will slip away as quietly as a shadow without the least sound of its wings. They usually nest in bushes and low trees, often building on large limbs. They do not usually gather in droves until toward autumn; whon the last brood of young is able to fly, one often sees 
them in flocks in the grain fields. They are recognized as game birds and are protected by law, and are on the increase in many parts of the country.

They are silent birds except for their love song, which is a sort of a coo-ow, coo, coo. Because of the mournfulness of these notes the birds are often called mourning doves. There are several species of doves, but the habits of all are similar. Their notes are so alike that a person who is familiar with one will recognize that of another. Nevertheless each variety has a distinguishing note so that any one who really knows the woods can recognize at once what variety of dove he hears cooing.

From the earliest days of history the dove has been a favorite, and has long been used as the emblem of peace and of all that is pure and good. 


\section{XIX}

\section{THE TURKEY BUZZARD}

QOME day when you are lying on the ground looking $D$ up into the clear blue of heaven, I am sure that you will see a great silent bird floating orerhead in wide circles without so much as a flutter of a wing. As you watch he will sail up and down, back and forth, hither and yonder, occasionally tipping one wing upward and then the other as he wishes to change his direction, always and ever sailing, sailing, sailing. I think no bird I knew as a child seemed so unreal and so wonderful as this bird. Hardly a day passed, summer or winter, when at some time in the day I could not see one or more of these great birds, but always they were sailing so high in the air that I could tell nothing about their appearance. Father and mother told me they were turkey buzzards- "turkey" because their head was bare like the head of a turkey, and "buzzard" because of fancied resemblance to a hawk. These buzzards are a type of degenerate hawks. I say "degenerate" because they have lost the bold hunter spirit of the hawks and have taken to the cowardly method of stealing or sneaking up on anything that they may desire for food.

Occasionally they kill for food, but when they do it is either some helpless half grown bird or some injured or crippled animal. Seldom do they attack anything that has 
size or power enough even to make an attempt to get away. Because of this lack of spirit they have found food hard to secure and have degenerated into eating carrion. No animal can be so far decayed or smell so bad that it is not considered good food by these birds. It is in the search of food that they are sailing, sailing, sailing, and they fly at the great heights they do so that they may see for miles in every direction. Doubtless no bird has a keener sight than turkey buzzards. They are able to recognize a dead animal at a distance of several miles, possibly further. One instance of my childhood days nicely illustrates this fact.

It was in the middle of a cold winter and food had been scarce for all of the birds, both the meat eaters and those that fed on seeds. The snow piled deep over everything and the thermometer seemed unable to rise above fifteen or twenty below zero day or night. We were so unfortunate as to have an animal die; as the ground was frozen too deeply to think of burying it, we simply dragged it off into a field at considerable distance from the house and left it on the snow. No one had supposed there were any buzzards in the country during this cold weather, in fact, at no time in summer or winter had we seen more than two or three buzzards at a time. Surely no more than a half dozen of these birds lived within ten miles of us. Yet within twenty-four hours of the death of this animal twenty-three buzzards were feeding on the carcass. It was a mystery to everyone where they came from. That was the first time I saw these birds at close hand.

The carcass in the pasture was only two or three rods from the hedge. It was easy to slip up behind this hedge and watch the buzzards feed only two or three rods away. 


\section{KNOWING BIRDS THROUGH STORIES}

A few crows came to the carcass now and then, as food of all kinds was scarce; and when they came the cowardly buzzards always gave way with squeals and demonstrations of anger and disappointment. As soon as the crows had completed their meal and left the carcass, again the buzzards fell to greedily. They seemed to eat like famished creatures, fighting and eating as rapidly as possible. When they were gorged to the limit, they merely hopped off a few feet and waited until they were able to eat more. Evidently it is the custom of these birds to feed ravenously when food can be found and then to go long periods without food. Doubtless the fact that they can fly without expending energy in flapping their wings enables them to live on much less food than other birds whose flying is vigorous exercise.

The second day after this animal had been dragged to the pasture a bald eagle appeared on the scene, the first I had ever seen, and for two or three hours, while he was feeding, not a buzzard dared venture closer than fifteen or twenty feet. If an overly anxious buzzard came a little too close, all the eagle had to do was to straighten up to full height and the cowardly bird ran like a rat from a dog.

Until some fifteen or twenty years ago, when I was raising poultry quite extensively, I had supposed these birds never ate anything but carrion. At that time we had a number of sick chickens-not sick enough to die, but half blind with swollen heads and so weak that they stood about paying little attention to anything that was going on about them. Suddenly one day two buzzards alighted in the poultry yard and each attacked one of these poor sick fowl. Since then I have seen buzzards follow for 

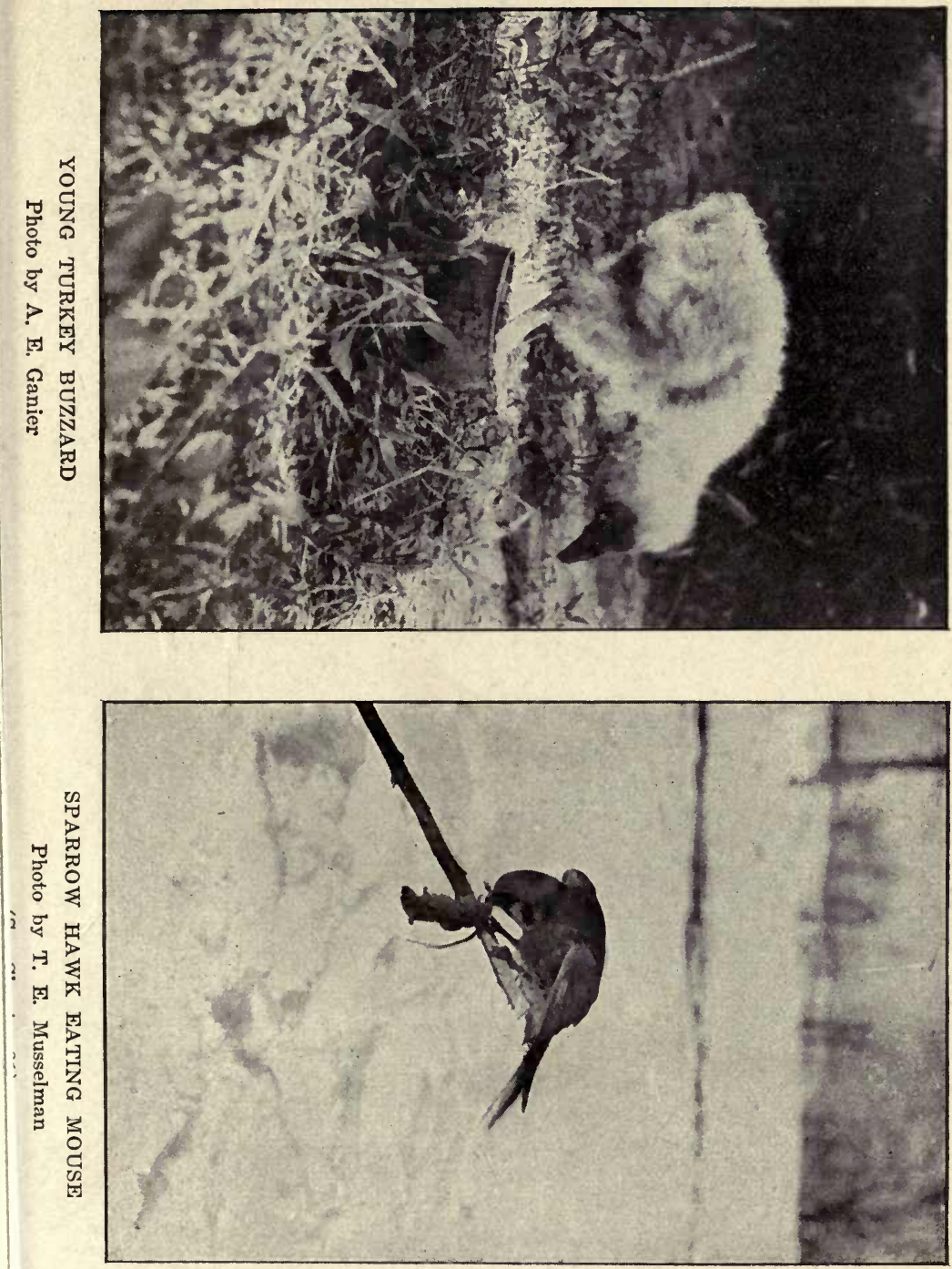


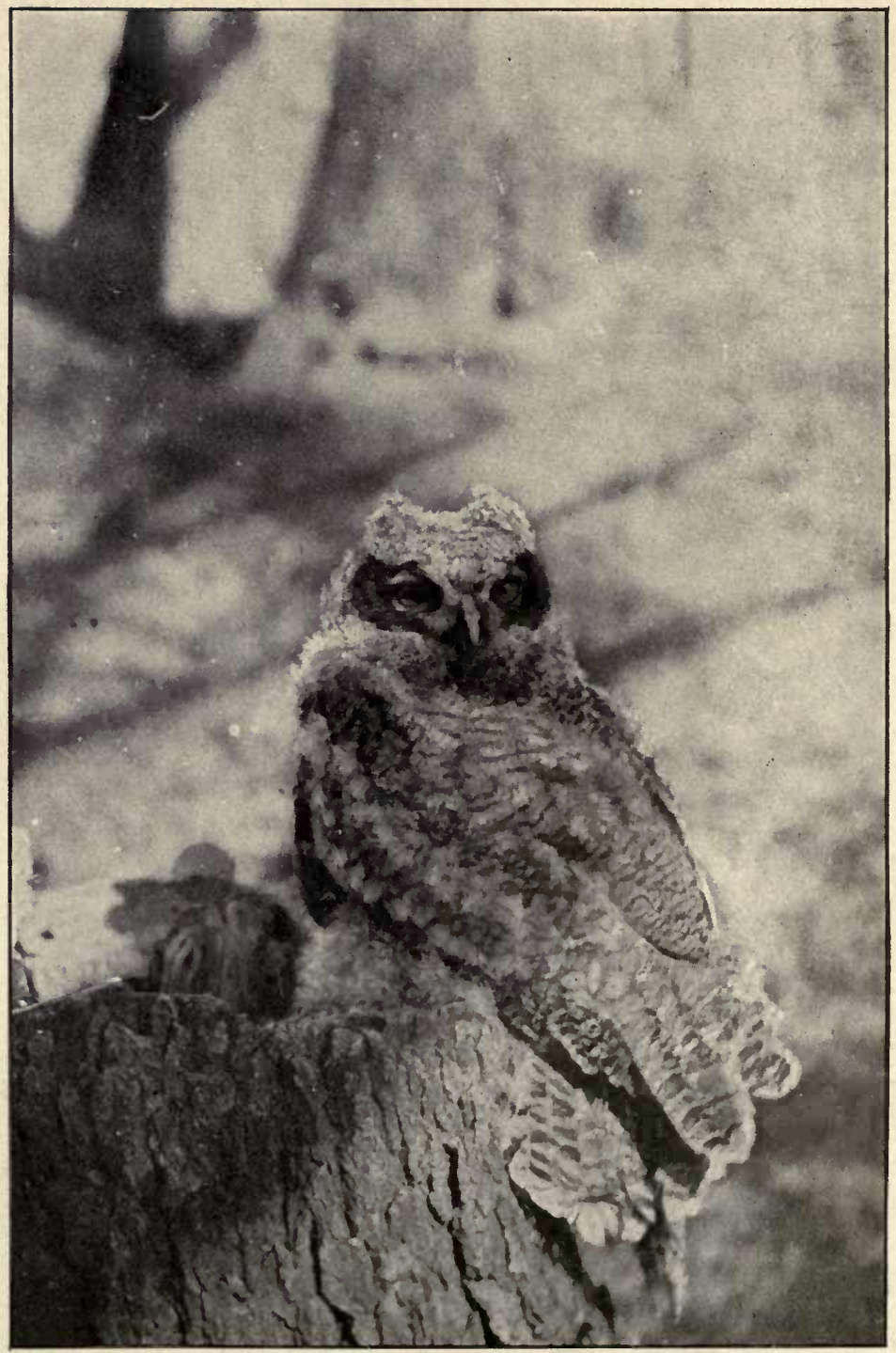

YOUNG GREAT HORNED OWL

Photo by Frank C. Pellett

(See Chapter 22) 
hours animals that evidently were so sick they could not live long, watching for the end to come.

These birds are wise in their own way, because they soon learn what it means to see a man start out with a gun. Strange to say, most States protect them simply because they are scavengers; and their flesh is so filled with poisons caused by their food that no living creature will eat them unless driven to it by extreme hunger. For this reason people seldom shoot buzzards. I have known these birds to follow a hunter for hours, hoping to see where he secreted any game he might kill; in case anything was hidden, or escaped after being mortally wounded, the buzzards would eat it in his absence.

In the Southern part of the United States buzzards are exceedingly numerous. In Texas and in Mississippi and Louisiana I have seen them by the thousands, especially on the outskirts of cities and about slaughter pens. The bird itself is rather remarkable in many ways. While it weighs only six and a half or seven pounds it has a spread of wings of at least six feet. The entire body is covered with long loose feathers which make it appear much larger than it really is.

In winter these birds like to gather on the south side of a bluff or in trees on the southern border of a large body of timber where they can sun themselves. I have found them in the woods of Tennessee in flocks of sereral scores sitting sometimes ten or fifteen on a single limb, lazily sunning themselves, occasionally yawning and stretching their wings, but never once have $I$ seen one of them preening his feathers. The fact is that at close range they always look dirty and disheveled. I am sure the buzzards are as filthy in their habits as they are in their 


\section{KNOWING BIRDS THROUGH STORIES}

food. In fact, it is true of birds as of people that bad habits of one kind are quite sure to develop equally bad habits of another kind. Occasionally as a child I used to find buzzard feathers in the spring when they were molting and scattering their great quills here and there over the fields. It was easy to recognize such feathers because of their stench. They smell like the food the buzzard eats.

Not so many years ago I found my first buzzard's nest. It was on the ground, as all buzzards' nests are, at the end of a log. Buzzards do not always build at the end of a log, however. If it is hollow they may build even two or three feet inside, or they may build at the base of a stump or a bush. I have known them to build on a dry tussock in a swamp so that they could be handy to the young cranes and herons that were near by. In fact, buzzards have a great preference for nesting in the midst of a colony of nesting herons. There they feed on the eggs and young herons without having to fly in search of food.

The nest I found contained two eggs about the size of the eggs of a common turkey, but they were a dull greenish white, and the shell looked thick and rough and was splashed here and there with a few brown spots. After these eggs hatched an occasional hour of watching enabled me to see the mother feed her young. This she did by disgorging her food into the young birds' mouths. When a buzzard's nest is disturbed the old birds will often fly overhead and attempt to disgorge food on the disturber, knowing that the smell will be sufficient to drive any man from the vicinity.

There are a number of varieties of buzzards, but the common turkey buzzard is most common all over the 
country. In California we have a giant buzzard that looks much like a turkey, even having white bars on the wings; but our common turkey buzzard is a dull brown color without beauty of any kind. Should you ever get near a turkey buzzard you will have no trouble in recognizing him by his bald red head and neck. This head and neck looks very much like the head and neck of a common turkey. The only birds that you could mistake for the common buzzard, either in flight or at any other time, is the giant black buzzard or carrion crow and one or two of the hawks. In flight all of these birds soar very much alike. I learned to recognize the difference when a child because all of the hawks find it necessary to flap their wings occasionally. In fact, I never saw a hawk soar more than a few minutes without flapping his wings, but buzzards will often fly for an hour without doing so. No one need have any difficulty distinguishing buzzards from the carrion crow because these latter birds have a square instead of a rounded tail, and the head is black. 


\section{XX \\ THE BALD EAGLE}

SPENT the summer of 1896 on the banks of the 1 Yellowstone River about eight miles above the city of Livingstone. The River at that point was full of fish of many kinds. In fact, suckers were so plentiful that the man with whom I stayed made it a practise each year to take a wagon and a pitchfork down to the edge of a shoal and fork out a load of suckers and bury them about his rhubarb, currant, and gooseberry bushes as fertilizer.

In a scrubby cottonwood tree near where I stayed was the first fish hawk's nest I had ever seen. The fish hawk, or osprey, is very powerful of flight and feeds on fish. I had read of those birds many times and was pleased to find an opportunity to study them at first hand.

I knew that bald eagles were common in those mountains. I had seen the historical eagle's nest on the top of pinnacle rock at the entrance to Yellowstone National Park, a nest that doubtless has been used for fifty years or more, and had found several other nests in the mountains. But it did not occur to me that any eagles lived near us, tho I should have known that inaccessible cliffs, a river full of fish, and an osprey's nest were a combination a bald eagle could not resist.

As I stated beore, the fish hawk had selected a scrubby cottonwood tree for her home, and late in April she built 
a nest not more than twenty feet from the ground. I do not believe she had been living in this vicinity long, for I had never noticed her until about the time she began building. She would fly down the river to a shallow a short way from where I stayed and would then hover over the river very much as a sparrow hawk hovers over a meadow when he has seen a mouse. This hawk would hang over that spot almost motionless, except for the flapping of her wings, for what seemed to be several minutes, when suddenly she would set her wings and dive headlong into the water. She was usually forty or fifty feet above the surface when she made her dive and would plunge completely under the water and sometimes remain submerged as long as a half minute. Then she would rise from the surface and, flapping heavily, mount into the air, often carrying a sucker eighteen inches or two feet long and as thick through as my arm at the shoulder.

One day in May I was watching her when I heard a scream in the direction of the mountain and looking around saw a bald eagle flying as rapidly as possible toward the hawk. Evidently the hawk had not been molested before, for she made no attempt to escape, but flew directly toward her nest, where my visit that afternoon had showed that she had youngsters. The eagle, being a more rapid flyer and not being burdened by a load, gained rapidly. When within perhaps fifty feet he again uttered his scream of defiance and struck straight for the hawk. She dodged and the eagle missed. Rising in a few short circles he again drove for the hawk and struck her full in the back. Tho a handful of feathers were torn from her back, evidently the eagle did not care to do real damage or possibly he had missed a direct blow. The hawk gave a cry 


\section{KNOWING BIRDS THROUGH STORIES}

of fright and dropped her fish, which was precisely what the eagle intended. She flew away rapidly, but the eagle, making a quick swoop, caught the fish long before it reached the ground and bore it in triumph to the mountains some two miles away. As soon as the eagle was out of sight, the hawk returned to her fishing. She had fished only a few moments when she caught another fish, which she bore safely home to her fledglings.

This eagle evidently had its own fledglings on some crag of the mountain near by. I tried several times to locate the nest but did not succeed. It came to be a daily occurrence to hear a scream and see the eagle coming from the top of the nearest high peak toward the hawk which it had discovered flying home with a fish. As the days went by, it was interesting to watch these two great birds match wits. If the hawk fished further up the river, she was fairly well concealed by some large trees and usually could manage to get away with her fish unobserved. On the other hand the water was deeper here, and she found it hard to locate her prey. Furthermore, her favorite fish, the sucker, preferred shallow water. So she usually chose to fish in the shallows in full view of the watchful eagle on the mountain above. When she made her catch, however, she was not long in learning to fly up the river as close to the surface as she could, for in that way she could often escape the notice of the eagle. On the other hand if the eagle failed for some time to see her catch a fish it would take to the air and sail back and forth high above the fishing grounds watching for the hawk.

After the one experience I never saw the hawk wait for the eagle to strike her before dropping her fish. On the other hand I never saw the eagle force her to drop her fish 
when she was directly over the water. Evidently the eagle realized that there was danger of the fish's being a loss to both of them.

The bald eagle is our typical American eagle, being found only in America. Except the golden eagle and California condor it is our largest bird of prey, and is found in practically all parts of our country. Its habit of robbing the fish hawk is practised from Maine to California.

It is very powerful of flight, but is not particularly bold. It catches many rabbits and other small animals, and occasionally a fish. I have also seen it disputing the carcass of a dead horse with crows and buzzards. Yet both these birds recognized their master in the eagle, for they preserved a respectful distance until it had dined and left the carcass. Then they again scrimmaged for its possession. Eagles often live to a great age.

It is interesting to watch an eagle's nest when the fledglings are grown and ready to fly. I have had this privilege and tell the story in detail in the history of a famous old golden eagle in my "Elo the Eagle and Other Stories." When the mother wishes to teach her eaglets to fly, she pushes them out of the nest, one at a time, and lets them flutter and fly as best they can. Should the fledgling be about to fall to the earth, she quickly swoops under it, receives it on her back, and mounts high into the air where she slips from under it and again allows it to use its wings. In this way it is only a short time till all of her fledglings are able to fly.

Bald eagles usually nest high. Where there are no trees they nest on cliffs; in the mountains the nest is frequently on a projecting rock on the side of a cliff or in some similar location, inaccessible to man. When a tall tree is se- 


\section{KNOWING BIRDS THROUGH STORIES}

lected it is often in the midst of a swamp, on a small island, or in some equally inaccessible place, and the nest is built of large sticks placed in the forks of a large tree. It is surprizing how large some of these sticks are-pieces five or six feet long and two inches thick not being unusual. Grapevines and smaller sticks are piled on these to form an almost flat nest. The same nest is used year after year, merely a few sticks being added by way of repair. Even tho the nest is robbed the birds seldom desert it.

The bald eagle can scarcely be mistaken for any other bird because, first, it is larger than the hawks and the buzzards, and, second, its head and neck are snowy white, something we never see in any other bird of prey. At present the bald eagle lives mostly in the timbered regions near the coast; but also in many places throughout the interior of North America, though it is there less common. 


\section{XXI}

\section{FLEETWING THE SPARROW HAWK}

THE first time I saw him he was chasing over the 1 fields close in the wake of another bird of almost exactly his own size but not quite so brilliantly colored. Back and forth they flew, circling and dashing first one way and then another, occasionally giving utterance to a shrill little cry. Whenever they came near, all the small birds took to cover at once. I probably would not have seen them had not the old white rooster called my attention to the fact that they were near. Immediately every hen in the vicinity gave a startled cackle and started toward the chicken house or into the brush near by. This sort of thing had happened so often before that I knew there must be some sort of hawk about. Looking around I saw two birds not much larger than doves dashing about over the pasture.

"Very well," I said to myself, "I will try to find time to locate your nest and study you this summer." You are perfectly harmless little fellows, and as far as I am concerned you may nest where you please. It may be interesting to see what you are about from time to time. There are a good many mice in the field and about the poultry yard, and if you will but decide to nest in the deserted flicker's hole in the top of the old hickory tree you will 
be given a royal welcome." With this I passed on. The next time I saw him was two or three days later. He was sitting on the very top of the old hickory tree where he could easily see everything that moved for a long distance; but I had no misgivings, for I knew that the sparrow hawk feeds largely on grasshoppers, beetles, and mice. It would be a benefit to have him rear a family so near, for he was sure to catch most of the mice that were living on the poultry feed and perhaps a few that stayed around the other buildings. I was sorry, however, that the nest was so high and so far out on a dead limb that it would be impossible for me to climb to it with safety.

The next time I noticed Fleetwing I was crossing the garden when a song sparrow flew by as if its very life depended on its speed, and truly it did, for just behind was Fleetwing. He was flying perhaps four or five feet higher than the sparrow and was gaining at every foot. I had no idea a sparraw could fly so rapidly, but in spite of his best efforts it looked as if he was doomed. There was a tree not more than a hundred yards away and suddenly the sparrow swerved from its course and flew directly toward this tree. By making this shift she gained a few feet, but quicker than I can tell it he had changed his direction also and was again in full pursuit. The hawk was no more than a rod behind the sparrow when it dashed into the tree and the disappointed hawk swerved upward with a scream of disappointment and flew back to the top of the hickory tree. Then it became clear why Fleetwing occupied this particular spot so much of the time. It was the highest point near; no bird could fly across the pasture or garden without being in sight, and he counted on being able to catch it before it got across. 
I also understood why the smaller birds keep near trees. I had never realized that hawks can not so easily catch a bird when it is in a tree.

When the first little chickens were hatched I placed two hundred in a coop on the grass not far from Fleetwing's nest. I felt safe in doing this because a sparrow hawk is not supposed often to feed on chickens; but within a day or two they began to disappear. Now began a real battle of wits. I got a gun, a thing which I had not had in years, and determined to shoot the hawks; but they succeeded in outwitting me. They managed to get three or four little chickens every day; and while I might see them catch a chicken, it was always either when I did not have my gun or when I was too far away to shoot. I spent hours watching for the hawks, but they never came near until I left. I did succeed, however, in learning exactly how these birds kill their prey, for I not only saw them do it at close range, but succeeded in scaring them away without their having time to carry the chick with them. The hawk watches until he feels sure of his prey, then swoops downward straight as an arrow, strikes the bird in the back with his talons, and with his powerful beak tears the top of the head off. The point of the beak is sunk into the base of the skull, and the skull is torn off with a swift forward motion. I succeeded in getting a number of chickens immediately after the hawk struck them, and every one had the whole upper part of the skull torn off, the brain exposed, and the medulla mangled with the point of the hawk's beak. After having watched this I felt much less antipathy toward hawks. True they kill for food, but they kill in a merciful and painless way, their method being instantaneous and almost painless. I have watched 


\section{KNOWING BIRDS THROUGH STORIES}

the pigeon hawk kill larger chickens and they do it the same way. Always the top of the head was torn off. It seems remarkable that these birds know that the brain is a vital spot and that of all the brain the medulla is the most vital. Fleetwing and his mate raised five as sturdy youngsters as a sparrow hawk could desire, and I did not succeed in getting any of them.

In spite of their method of feeding sparrow hawks are wonderful creatures. They alternate in sitting, the mother bird sitting perhaps no more than her mate. They are equally alert and apparently equally successful hunters. They show strong affection for each other, and while one is sitting the other is quite sure to bring food at least once every two or three hours. I have seen Fleetwing carry, food to his sitting mate frequently, but no more frequently than I have seen her carry food to him when he was performing the same duty.

When the youngsters were able to leave the nest the parents began systematic teaching. The youngsters were taken to the middle of a large pasture where the whole family alighted on the ground. The first lesson consisted in hunting beetles, grasshoppers, and crickets. Evidently insects are considered an important item of food because they are so easy to catch, and the youngsters must learn what to do for a dinner in an emergency. A bird would. perch on a tall weed, or skip from weed to weed watching the ground intently. Every few moments it would pounce on a grasshopper or a butterfly.

Next they were taught to hunt mice. Then father and mother would hover over the meadow and the young birds soon joined in the game. A hawk would fly over the meadow until something attracted his attention below. 


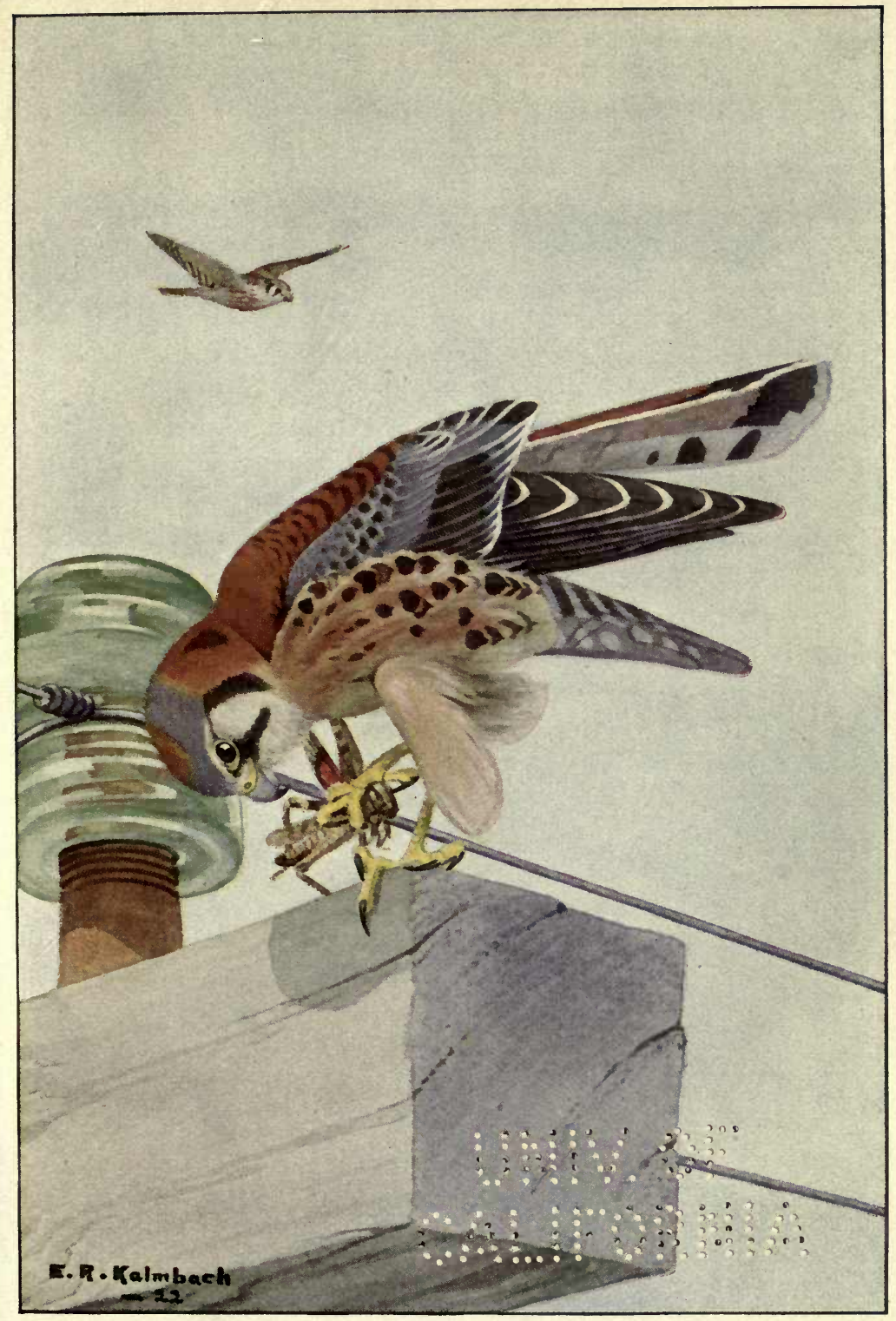

THE SPARROW HAWK 

Instantly he stopped and by fluttering his wings up and down would hang almost still, moving neither downward nor upward. All the while he was watching for the least movement on the earth below. If a mouse made the least movement, quick as a flash the wings were turned backward and the bird would fall like a bolt from the clear sky. Just before striking the ground the tail was slightly tilted and the wings spread just a little and the bird would strike the mouse and glide up again without touching the earth. This requires great skill. Sometimes hawks fall from great heights and gain great momentum, but practise has given them such skill in judging distances that they are able so to adjust wings and tail that they can pick up an animal, no matter how small, without striking the earth. The next spring Fleetwing and his wife were on hand with the first young chickens. I did not discover where they nested that summer, but they were even more skilful in catching little chicks than before. I am sure that this pair of birds caught not less than one hundred little chickens the second summer without my being able to prevent it. The third summer they started preying on my chickens again; but they were getting over-confident, feeling sure they were able to outwit me. One day I hid behind the chicken house when both birds came for their breakfast. As was customary they alighted on the old hickory tree to locate the particular chicks they desired. I shot the mother bird before she could get out of range, but did not kill her. For two hours I followed the two from place to place, never getting closer than a long range shot. Three times I shot this bird, but Fleetwing never deserted her. Wherever she went he went also, always keeping nearest me in a vain effort to draw me after him. 
Finally she alighted in the top of a tall tree, too badly hurt to fly again. A fourth shot brought her to the ground. Did this end my troubles? No, within three weeks Fleetwing had a new mate and is still living in the vicinity. He has, however, given up chicken stealing and has confined himself to English sparrows and other legitimate prey. The past season he nested in the timbers of our water tank. So long as he leares the chickens alone he may live there undisturbed.

The sparrow hawk is one of the smallest of the true falcons. We have three families of hawks, but the falcons have always been most admired by man. Before guns were invented, falcons were trained for hunting purposes. The bird was carried to the field with a hood over his head, and when game was sighted the hood was removed and he was released. The better trained falcons would frighten a goose, duck, or a heron, and chase it until it flew almost directly orer its master before striking it. Then with one lightning swoop it would strike its victim, either breaking its neck or crushing its skull, and seeming to rejoice when it fell at the master's feet. In Oriental countries some of the falcons were used even in hunting deer.

Falcons are almost the only hawks that catch poultry or do any considerable damage. Most other hawks are not active enough in flight to catch many birds in mid-air. They feed largely on rabbits, mice, rats, and other small animals, and are a benefit rather than an injury to man. Falcons can be recognized from the other hawks by their trim, slender build, and their longer, narrower wings. They do not sail about so much as do the other hawks, but more with a quick, nerrous motion. Many 


\section{FLEETWING THE SPARROW HAWK 143}

of the falcons are beautifully colored and nearly all of them are more or less spotted or streaked, especially on the belly and breast. Practically all nest in the hollow trees or on cliffs or in some other inaccessible place. 


\section{XXII}

\section{SILENT WING THE GREAT HORNED OWL}

T was one cold stormy day in February. All day the 1 wind had howled, and spiteful little gusts of snow had sifted it down over the nest in the yawning hole. As the twilight began to gather the mother bird arose and, sticking her great horned head out of the hole, glanced sharply about and then settled down again over five fuzzy little babies that she had kept warm for the last thiry-six hours without stirring from the nest. The storm should have spent its fury by this time, but to her consternation there was no sign of abatement. The babies must be fed, for though most of the wildlings that kill for food must accustom themselves to long periods without dining, her babies were too young to fast for any great length of time. Two nights ago her mate had brought them their first taste of flesh and departed in quest of more, but now they were chafing under the long wait for another feed. If only the wind would settle and the sky clear she could go and hunt! But these babies were too young and too hungry to stand the chill of cold snow sifting in over their backs, and this was precisely what would happen if she left them now. Why had not her mate come long ago, bringing provisions for the family? She had heard him sound the terror cry several times that night, and surely some foolish chicken 
must have lost its nerve enough to move or cackle at the sound of that terrifying cry, but he had brought none home. Later she had heard the report of a gun, but guns fired at night seldom do harm, and surely so wise an owl as her husband had not met disaster by this means. She would patiently wait, for hunger was to be preferred to cold.

Moments passed into hours and still she waited. Near morning the wind sank to rest and the moon shone forth brilliantly. Hastily slipping out of the nest she sailed to the top of the tallest tree in the neighborhood and began scanning the landscape. Things were not altogether to her liking, for the moon was full and its light on the new fallen snow was blinding, but she must succeed in her quest for food. While she was trying to decide which way to go, Molly Cottontail and her foolish brother emerged from the crabapple thicket and started a game of tag in the open field near by. Back and forth they raced, rejoicing in the feel of the soft snow, their minds wholly bent on the game. This mighty hunter of the night knew that even two foolish rabbits engaged in a game of tag would scurry to shelter should a shadow fall across their path, so she flew around the field keeping behind the tree tops so she could cross the field "up moon," so that her shadow would fall behind. Swiftly she flew, silent as the shadows that flit across the field. Molly ran down the field and squatted behind a little bush and waited to startle her playmate when he should come dashing past in pursuit, but she waited in vain. The silent wings swooped downward and, with a scream of triumph that was meant to tell the waiting babies that all was well, the great bird carried the warm limp form to the nesthole. Without thinking too much about the fate of her husband and the outlook for the future, 
the mother settled down content with the present, glad that she had selected for their home the great hollow tree that grew on the very bank of the river where she could always put its watery breadth between her and her enemies should danger appear.

In the meantime her husband, wounded and sore, was trying to find a way of escape from the corn crib in a neighbor's barn. On the night when he left home he had flown directly to a barnlot where past experience taught him that he would find white chickens roosting in trees. Alighting in the top of a great elm, he looked about for the chickens, but they were nowhere to be seen. Knowing he could not see colored fowls unless they moved, he sent forth his mighty challenge, but nothing moved except a mouse in the edge of the straw sack. His wonderfully acute ear caught the sound and there being no intimation of larger game, he flew directly to the spot and caught the mouse. Great horned owls prefer larger game than mice, but on a cold winter's night nothing that will do to eat is to be despised, especially when there is a hungry family at home. Hastily swallowing the mouse, he flew back to the tree and again gave his challenge. Still nothing stirred. Seeing and hearing nothing, he flew directly to the top of the pole in the middle of the haystack, where he felt that he could get a nearer view of the house which the man had made for his chickens; but as he alighted, he was startled by a snapping noise and something caught his leg that burned like fire. Hastily taking flight, he was jerked back by the chain of a steel trap and each time he tried to escape he succeeded only in hurting his leg. 0 , the agony of the hours that followed! Over and over he tugged and strained, sometimes flying this way, sometimes that, and 
then, when exhausted, hanging by the chain with his head down. Finally, at his wits' end, he alighted on the top of the pole and was sitting there resting on his uninjured foot when daylight came.

He did not flinch when the man came near, but, ruffling his feathers and snapping his bill, he was ready to defend himself to the last. But what could he do? When the man came near he attempted to use the talons on the uninjured foot, but he could not cling to the pole with the injured one and so again suffered the agony of hanging by. the chain. He was taken from the trap and put into the corn crib, where the boy saw him a day or two later. There were plenty of mice in this crib and he was expected to become a pet for the privilege of being confined where he could catch the mice that were playing havoc in the corn. That was why he brought no more food to the hungry family.

Things ran on as usual the latter part of February and the first of March. One day was warm and the next stormy, with flurries of snow interspersed with sleet and rain. The mother owl was sadly handicapped with five baby mouths to feed and no one to help; but she never whimpered, and never did it occur to her that she might desert her family.

Ringtail the coon sived hard by, and for a week or two the poor mother never left home without the deepest concern lest he, while prowling about for his supper, should happen to poke his nose in the hollow tree and discover the precious babies. Ringtail, however, knew the terrors of a great horned owl's talons, and somewhere back in his wise little head was stored the knowledge that if hunger pinches too hard these mighty hunters do not hesitate to catch even 


\section{KNOWING BIRDS THROUGH STORIES}

a full grown coon. His sensitive nose told him that a great horned owl lived in this hollow tree, but to him it would have been the height of presumption to investigate her home.

The boy had a habit of wandering up and down the river in search of whatever story he might discover. Abnut a week after the catching of the father owl he happened by the nest. By this time the babies inside were growing rapidly, and already the fluffy fuzz was beginning to give place to pin-feathers. They no longer needed careful brooding, and often the mother elected to roost in the clump of swamp willows a hundred feet from the nest. Here she felt more secure both because she could more easily get away if danger came and because if she had to flee from these willows she would not hetray the location of the precious nest.

The boy happened to stumble into this clump of willows. The sun was bright and its reflection from the snow that had fallen the night before made such a dazzling light that when the owl awakened she merely straightened up, blinked her eyes, raised her horns to their greatest height, and began looking around to locate the intruder.

The boy knew that in spite of the fact that great horned owls were believed to be plentiful because of the large numbers of poultry they carried away, in all probability there were no more than one pair in the neighborhood. Looking about for the mate to this owl, his eye fell on the hollow tree. At nesting time owls seldom sleep far from home, and the boy expected not only to find another owl nearby but hoped to locate the nest. Great horned owls usually build a giant stick nest two and a half or three feet in diameter on a spreading limb not far from the trunk of 


\section{SILENT WING THE GREAT HORNED OWL 149}

some great tree. As careful examination did not reveal such a nest, the boy turned his attention to the poor blinded owl that sat blinking on the limb. Stealthily he moved, in the hope that he might get near enough to catch the bird before it saw him. Just as he thought her within his reach, she became aware of his presence and flew directly across the river.

The boy was about to move on when it occurred to him that the other owl might be roosting in this hollow tree. Placing a fallen limb against the trunk, he climbed up and peeped in, and what was his surprize to see not one pair of great eyes staring at him, but five pairs, and hearing the snap of not one bill but of five. The boy remembered the owl in the neighbor's corn crib, and it occurred to him that here was the nest of that owl with only the mother to care for the family.

The fright of being aroused in the daytime over, these young owls began to make a soft, murmuring noise pleading for food. The boy always fed any young birds that he could induce to eat, if it were possible. He had a few small minnows with him, so cutting them in pieces with his jack-knife, he fed the five hungry birds. There is no food that a great horned owl relishes so much as fish, though few ever learn to catch it for themselves. They do not usually feed on carcasses, but so fond are they of fish that when a dead one is found it is eagerly devoured. When he put his hand in the nest with the first piece of fish all but one of the young birds crowded to the furthest corner of the hole. Snapping his little bill, this one boldly caught the boy's hand with his baby talons and started to defend himself. But the smell of the fish soon quieted his fear, and he allowed himself to be fed. One 
after another the others overcame their fears and dined for the first time on fish. The boldness of Silent Wing won the boy's heart, and he determined when the proper time came to take him as a pet.

Ever afterwards, when the boy visited the nest, Silent Wing always showed greater boldness and was more friendly than any of the others. He and the boy became great friends, and the boy learned to recognize him and to distinguish him from his fellows.

After the birds were fed they felt assured of the good intentions of their visitor, and permitted him to take them out of the nest and set them in a row on the limb, tho they protested against the blinding light by snapping their bills and blinking their great golden eyes in the most droll way. Soon, one after another, they began to doze off, and the boy put them back into the nest and went his way with the determination to visit them as often as possible; but he kept to himself the secret of their existence.

The great horned owl is one of the largest American owls. It has a spread of wing of four or five feet, and often grows large enough to kill a half grown turkey and carry it off. It lives largely on poultry, the larger wild birds, and rabbits or squirrels, tho occasionally it catches even opossums and woodchucks. Most varieties of owls are beneficial, living on mice, rats, and other small rodents and large insects. In the early days, when these owls were plentiful and poultry houses all but unknown, they earned such a reputation as chicken thieves that the whole owl race has suffered at the hands of man ever since. This owl is still occasionally met in practically every State of the union. It has such an abundance of warm fluffy 
feathers that it does not mind the most intense cold and for this reason those in the United States do not migrate, tho if food becomes scarce in one neighborhood they may move to another.

A few days before our birds were ready to leave the nest the duck hunter of the neighborhood happened by. This man killed not alone for the fun of killing but for the fun of telling about it later. To kill a great horned owl would furnish something to talk about in his favorite loafing places for days to come. Wild geese and ducks were coming in abundance and he was now tramping up and down the river almost every day, from long before sunrise till it was too dark to shoot.

And so he came to the hollow nest tree. What is the need of telling more? His sharp eye detected the owl dozing in the willows. She heard him and promptly started to cross the river, but even a river is no protection against swift-flying duck shot. She fell in the middle of the stream, whether dead or alive the hunter never knew or cared, and was soon carried out of sight by the current. On the way home that evening he passed the boy's house and after showing his string of ducks incidentally mentioned killing the owl. Then the boy knew it was "up to him." These birds must not starve. One he might hope to keep at home as a pet but never would he be allowed five.

That night his trusty target rifle was given a thorough cleaning and early the next morning he sallied forth to secure a supply of rabbit meat to feed his wards. Sour milk curd was abundant just then and that would make a welcome addition to the stock of provisions, and a few days' care was all the fledglings could hope to receive. The boy's mother was always a sympathizer and a confederate 
under such conditions, and as it was two miles to the nest the boy decided to make a confident of her, for otherwise it might prove hard to get away to feed his wards. She consented to the care of the birds and suggested that he move the entire family to the old hay barrack, where they might be conveniently fed, trusting that their inherent shyness would lead them to leave the place as soon as they were able to fly, but this proved not to be necessary. When the boy went for his wards he found sitting on a limb near the nest an owl with one foot swollen and crooked, showing plainly that it had been injured at no far distant time; and when he looked in the nest he found the remains of a Plymouth rock chicken that the young birds had not been able entirely to devour. Discreet inquiry revealed the fact that the day before the corn crib door had been left ajar for a few moments and the captive owl had escaped. Loyal soul that he was, he returned to his family too late indeed to find his faithful mate, but in time to save the young from starvation. With the boy's occasional help he fed the family, the members of which were soon able to care for themselves. For some time after the young birds were able to leave the nest they followed the father at night, not only begging for food but learning the ways of the woods and how to catch a living for themselves. Then they scattered never to come together again as a family.

The great horned owl is also a solitary bird. Even where most abundant, seldom more than one lives within a radius of a mile or more, except in nesting time. Instinctively, the young scatter miles apart as soon as they are strong and wise enough to care for themselves.

Unlike many owls, they sail readily and gracefully, rising, falling, and moving forward without the necessity 


\section{SILENT WING THE GREAT HORNED OWL 153}

of flapping a wing. They are typical owls, having the characteristic short, stout, hooked beak, the large eyes with rosette-like feather discs around them, the short stout tail, and the sharp, powerful talons. Owls are usually easy to identify by these marks, and by the fact that with one or two exceptions our owls hunt by night and sleep by day.

The great horned owl has a variety of calls. Sometimes he utters a cry closely resembling the rapid, staccato barking of a cur dog. Again he shrieks much like the cry of a panther or the scream of a woman in distress. More often he utters a deep "whoo, hoo, hoo." He moves his beak and even the whole body in the most grotesque way when uttering these sounds, snapping his bill loudly in the intervals.

Things ran along as they do in the busy life of every country boy until threshing time came. One evening an hour before sundown, the threshing machine unexpectedly pulled into the yard, and his father, realizing that no provision had been made for help, started out on horseback to notify the neighbors with whom he expected to exchange work that the machine had come.

Stalker's woods, a heavy body of timber of some eighty acres in extent, lay between the boy's home and that of his married sister, and through these woods the boy as messenger must pass to reach her home. He was too young to notify the neighbors of the situation, but he could walk across the fields to notify his married sister that her help was needed in the kitchen the next day. Dan Scott had told the boy so many stories of witches, ghosts, hobgoblins, etc., that he was afraid to poke his head out of doors after dark. With fast beating heart he set out on his trip, hoping that he might make the return trip early enough to get 


\section{KNOWING BIRDS THROUGH STORIES}

through this dreadful piece of woods before dark. But hurry as he might, the sun set before he reached his destination. Knowing he could not stay over night and ashamed to ask someone to accompany him home, he delivered his message and started homeward as fast as his weary legs could carry him. When he entered the woods twilight was already falling, and before he reached the other side it was dark. This was the first time the boy had ever been out alone after dark, and the fact that he was in the very woods where a coyote had been seen only three days before, where also wild cats were still believed to live, did not add to his peace of mind. When he was nearly through the woods he heard a "snap, snap" in a tree near by, and then the most unearthly, blood-curdling scream to which he had ever listened. The screaming of a woman who is being murdered added to the sobs and sighs of the lost could not be more terrible. The boy's hair rose up straight on his head. The cold sweat came out on his brow. He tried to run, but his feet were rooted to the ground. The agony of ages followed. A second blood-curdling scream came from the tree just over his head and then followed the softest, gentlest "Whoo-hoo-hoo," and a great horned owl alighted almost by the boy's side. Relieved? Well, rather! He knew that this owl was not attacking him, and then he recalled his father's stories of how the scream of the great horned owl, although heard only at rare intervals, can scarcely be distinguished from that of the female panther. Undoubtedly this was Silent Wing, who was hunting in these woods and recognized the boy as his one time friend and in the best way he knew was expressing his delight at finding him again.

This bird would not quite allow the boy to eatch him, 
but when the boy started on, he flew from tree to tree, snapping his bill after the manner of his race, and when the boy left the woods and entered the big road the owl flew out across the open field in search of his supper.

One evening during our usual January thaw a female owl flew to our grove, and alighted near the grapevine playhouse. By some accident (or was it an accident?) Silent Wing flew directly across the fields from Stalker's woods and alighted in the same tree. The call of spring was strong in his veins-the mating call of the wildlings. Silent Wing no sooner saw her ladyship than he knew he wanted her and he wanted her right now.

So he began bowing his head, ruffling his feathers, raising his wings and spreading his wings in a curious manner, making himself appear so ridiculous that the boy in the grapevine swing would have laughed outright had he not been fearful they would leave. Aside from watching his antics, she took no notice of his presence. Growing more earnest, he began hopping from branch to branch, continuing his maneuvers and snapping his bill fiercely as if to show that even tho he was not so large as she, what he lacked in size he made up in bravery.

Finally, he attempted to approach and caress her but she ruffled her feathers and rebuked him sharply. He took flight, sailing up and down, around and around, evidently doing all the stunts of his race, now and again punctuating his efforts by snapping his bill. After a few moments he alighted again and began his bowing and dancing all over again.

A rabbit came running down the bank and its white flag caught his eye. Rising in noiseless flight, he sailed downward without the flap of a wing, caught his prey from 
the ground, glided back into the tree, and presented his offering to his lady love. Apparently, she was convinced of his sincerity. Together they devoured the rabbit, and when he again began his love dance she joined in with as much enthusiasm as he. The last the boy saw of Silent Wing he and his bride were flying across the fields toward Skunk River.

\section{Key to the Families of Raptores}

Birds with firm plumage.

Cathartida-American Vultures.

Large birds with the head entirely unfeathered, the nostrils longitudinal. and the hind toe elevated.

Pandionide-Ospreys.

Rather large birds with sharp, strong, curved claws all of the same length; head feathered; hind toe on the same level as the other toes, and the outer toe reversible.

FALCONIDE-Falcons and Caracaras.

Small or rather large birds with characters similar to PANDIONIDR, but with outer toe not reversible, and claws not all of the same length; nostrils circular with a central tubercle, or narrow and set obliquely with the lower end anterior,

ACCIPITRIDE-Hawks and Eagles.

Birds of small or large size, similar in characters to FALCONIDR, but with nostrils not circular nor narrow and set obliquely with the lower end anterior.

Birds with rather soft plumage.

BUBONIDA-Horned Owls.

With eyes directed forward and surrounded by disks of feathers, and inner toe shorter than middle toe.

TyTONIDE-Barn Owls.

With eyes directed forward and surrounded by disks of feathers, but inner toe as long as the middle toe.

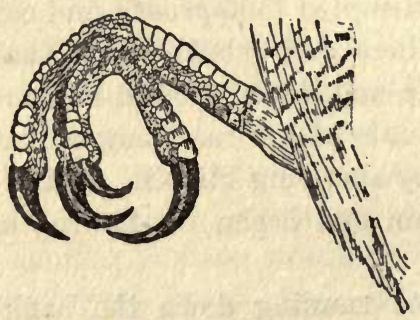

Foot of Typical Hawr 


\section{XXIII}

\section{THE BELTED KINGFISHER}

T was my first trip to the lakes and woods of Michigan, 1 and everything seemed strange and new. I was well acquainted with the birds, plants, and fishes of our own woods in southeastern Iowa, but here things were different. I never before had seen anything nearer the size of a lake than the ponds along Skunk River, which owe their existence to the overflowing of the river from time to time. At the first opportunity I wandered into the woods by myself merely to see what I could find. I had heard many stories of the wild animals that still roamed in these woods, and had been told that bears, wild cats, and Canada lynx were frequently caught. I had spent days and weeks in the woods, and knew that the wildlings, when not pressed by extreme hunger, are harmless; so it was the farthest thing from my thoughts to be afraid, but I was on the alert for new things. Even the trees were different from those at home, not only because they were of different kinds, but because of the different soil and climate; even the varieties with which I had been familiar all my life looked different.

Pushing through the underbrush in search of a flower I had seen at a distance I stumbled unexpectedly on a beautiful little brook, and almost at the same instant was 
startled by a rattling crackle from something near by. I couldn't imagine what it could be. No animal of which I had ever heard would give utterance to such a sound, and I was sure no bird could have so unearthly and unmusical a cackle as this. Freezing in my tracks, I began peering up and down the creek to see what I had disturbed, but nothing was in sight. The challenge had been so sudden and unexpected that I was not sure from what direction it had come, and as I was unwilling to let anything so unusual go unexplained and felt sure that whatever I had disturbed would return, I settled myself by the edge of the water to see what would happen. When I became convinced that the creature was not in sight, I turned my attention to other things. I had not been accustomed to brooks so clear that one could see what the fishes in them were doing as readily as one can see those in the globe on the parlor table. But here I could see dozens of croppies, coontailed bass, and sunfish as beautifully colored as any goldfish could be. Anxious to study these creatures, I moved over on a log that had fallen partly in the water, and began my childhood tactics of coaxing the fish to come near by throwing grasshoppers into the water. At first, all were shy, but hunger was insistent, and finally one fish after another got enough courage to dart up and swallow a grasshopper; finally seeing no harm come of it, they grew so tame that they did not hesitate to swim within touch of my hand, and one of the boldest even ventured to take a kicking grasshopper out of my fingers.

All this doubtless had consumed several hours, for when one becomes interested in the little creatures about him, time passes without notice. Finally, I became conscious that a bird had alighted on the limb of an old snag that 
was sticking out over the water and not twenty steps away, and looking up, I was dumfounded to see a great awkward bird that seemed all head and bill. This bird was wholly new to me, and of course the fish were forgotten in the new interest. I had never seen a picture or heard anything that gave me any clue to what this bird was. Presently the bird straightened up, ruffled his topknot, and looked more grotesque than ever. Then he settled down quietly to watch the water. Evidently he had not noticed me, and I sat immovable-the only way one can become really acquainted with the wildlings. For perhaps ten or fifteen minutes he sat perfectly still, and then without warning this strange bird apparently fell off his perch head first into the water. He dropped straight and stiff as an arrow, and it was not until I saw him rising out of the water with a fish gleaming in his bill that I became aware that he had not had a stroke of apoplexy, but was really alive and that this was his method of earning a living. He lighted on the snag from which he had fallen and began vigorously hammering his prize on the limb. When he was convinced that the poor fish was beaten into insensibility he flew up the brook carrying it with him.

Already the sun was low in the west, and tho I was reluctant to go without learning more about this interesting stranger, I turned homeward. As soon as I met some one who I thought would take some interest in the matter, I told the story of what I had seen, and to my surprize found that I had made no discovery at all, but was merely telling the story of one of our best known and most widely distributed birds, the belted kingfisher.

I have since traveled much in almost every part of these United States, and have found these birds practically 
everywhere with the exception of my own home country, the southeastern part of Iowa. There the water is usually too muddy for fish to be seen. There is some variation in the size of this bird in the different parts of the country, but the difference is not great. Everywhere this solitary bird reigns supreme as the king of fishers. He never has time to play and knows nothing of song save the rattling "Rickety, crick, crick, crick" which he sends forth when he sees an unwelcome stranger in his domain, and he waits for this until he is on the wing and safe out of gunshot.

A few years ago, on the banks of White's Creek, near Nashville, Tennessee, I had an opportunity to study the kingfisher at leisure and to watch his home life. Unlike most birds, the kingfisher does not seem to mind the cold. As long as there is open water and good fishing, he does not migrate, no matter what the temperature. I have seen him in Montana fishing in the mountain streams when the thermometer stood at thirty or forty degrees below zero without seeming to mind the cold in the least; and he was the same busy silent fisher that $I$ had seen in the middle of the Michigan summer. So in Tennessee I was not surprized to find him on the same sycamore limb almost every day in the year.

The kingfisher is a solitary bird, and loves nothing, so well as to be alone; but after the high water in the spring of 1912 two kingfishers decided they would forego the privilege of being alone for the privilege of raising a family, and that it was time to get busy. After flying up and down the creek togethe $\bar{r}$, examining every bank that looked as tho it might be above high water mark, they selected a spot about ten feet above low water level, and 
started scooping out a hole in the side of a mud bank, using their mighty bills as we would a pick. A quantity of earth was torn loose, and then scratched away with their claws. By persistent hard work they soon had a tunnel in the side of the bank three or four feet deep and perhaps three or four inches in diameter.

This hole did not run straight, but twisted to one side about a foot from the entrance, and then sloped up a little. I have dug out very few kingfisher's nests, but they all ran back five or six feet into the bank, and I have never seen one that went in straight, tho other persons report that they often follow a straight course. At the back end of this hole a little enlargement was made in the earth, and a few pieces of grass were piled about; hardly enough to be called a nest, just enough to show that mother kingfisher felt it her duty to do something. I did not see the eggs and do not know whether one was laid every day or not. The fact is, I did not care to disturb the nest because I wished to watch the development of the family.

In May the mother must have begun sitting, for then I seldom saw more than one bird at a time. But about the last of June both the birds were to be seen again, actively fishing most of the time, so I took it for granted that the young were hatched, and were old enough not to require much brooding. The mother bird, however, did her fishing nearer the precious hole than did the male, tho I do not know that she would have done anything if an animal had bothered the nest. Certain it is that when I would go to the mouth of the nest hole, she would fly away with the same rasping, rattling cackle she would have used if there had been no nest in the vicinity, and would not return until I had left the place. Probably she felt that her deep 
excavation in the bank was all the protection her babies required. But with the large number of snakes that lived along that creek, every one of which had the habit of crawling into holes, it has always been a mystery to me that none of them bothered the young kingfishers. More than that, Bobby Mink traveled up and down the creek every night catching crawfish, minnows, and anything else that came in his way. Knowing that the mink has a habit of poking his nose into every hole he passes and is never content to stop until he has explored it to the end, I have wondered that he did not dine here, but doubtless the mother bird was in the hole at night and her powerful, sharp beak ought to be sufficient weapon to drive away even a hungry mink.

Then both birds were even more absorbed in fishing than usual, but as at that time there were schools of minnows everywhere, it was not difficult to catch plenty even for a family of five babies.

I had supposed that a kingfisher was very sure to make a catch when he dove for a fish, but, whether or not necessity led them to take greater chances than ordinarily, these birds missed fully twice as often as they succeeded in catching the fish after which they dove. I often watched one of these birds sitting on a sycamore limb over a favorite pool. A white gleam would flash from the water, showing that a minnow was playing beneath, when there would immediately be a splash in the water. If the bird failed to make a catch, she usually promptly returned to the same limb and waited patiently for an opportunity to try again. If she caught her minnow, she usually flew directly to the nest without stopping to kill it. She alighted on a stone near the entrance, however, and beat the fish over the stone 
a number of times before entering the hole, tho I do not think she ate it.

When the young were half grown, they usually met their mother at the entrance of the hole. This never seemed to please her very well, for she steadily refused to feed them until they were well back under the ground. Of course this meant that I could not see her feed them at all. A young kingfisher is the most awkward, ungainly, ugly looking bird I have ever seen. Every feature of the old bird is exaggerated in the babies. They have such disportionately small feet and legs, and such ridiculously small naked bodies, crowned with such a large ugly head, that it is hard to see any beauty in them.

When the young birds were able to fly, which was about the middle of July, I dug out the nest, and it was a filthy sight. Most birds are cleanly in their habits, and are especially particular about their housekeeping, but not so with the kingfisher. The nest hole was a reeking mass of putrified fish, feces, bones, etc. The kingfisher must have a great deal of resistance to disease in order to be able to live and thrive under such filthy conditions.

The young birds did not remain in the neighborhood of the nest more than a few days, but those few days were busy ones, for in that brief time the mother was teaching her children how to earn a living. She would perch by their side on an overhanging limb and patiently wait for the glimmer of a fish below. The first day or two she usually caught the fish, beat it into partial insensibility and then dropped it again into the water. The young were persistent in their plea for food, but the mother was as insistent that they catch their living if they got any. There was very little current where they hunted, and a fish did 
not float out of sight quickly. The young birds would crane their necks and look hungrily at the fish below until finally one more hungry or more bold than the rest would make a dive for it. At first the aim was not good, and the bird would miss even a dead fish more often than he succeeded in catching it. Usually, however, he fluttered about the surface of the water until he got his fish, even tho he had missed it when he made his plunge. Old birds never hover about the water if they have missed their aim, for they have learned that there is a vast difference between a live active fish and one that is stunned and half dead. During the first few days when the young birds became too hungry, the mother would occasionally relent and feed them, but before the week was over, no matter how hungry they became, no food was coming until they caught it. Within ten days the young birds were catching live fish instead of half dead ones.

Then a young bird would catch his fish, carry it to his perch, whack it over the limb a few times, toss it in the air, catch it by the head as it came down and swallow it with as much skill as his mother. As soon as she was convinced of the skill of each of her brood, she forsook them entirely. I do not know whether she ultimately drove them from the neighborhood or whether they left voluntarily, but when July was past only the old birds were to be seen in the neighborhood. I became too busy to watch them longer, so never knew whether they reared more than one brood that summer or not. I do know that long before frost the pair had parted, her ladyship keeping the good fishing ground in the vicinity of the nest, while her spouse fished alone a half mile up the creek.

The kingfisher is an exception to the general rule 
among birds and animals. The female is more brilliantly colored than her spouse. She is easily recognized from the fact that she alone has the rufous belt across her abdomen. She is easily the head of her household, and usually has the best of everything.

Kingfishers are common in other countries, and there are a great many kinds varying in size from no larger than a sparrow to birds larger than a small crow. They belong to the family Alcedinida, and can always be recognized by the large head often with the feathers sticking straight up, the long sharp beak, the powerful wings, and the short stubby tail. No other bird looks much like them. Our own kingfisher is about thirteen inches long from the end of his beak to the end of his tail. His back and upper parts are a blue gray, with light and dark spots on his wings and tail. His throat and upper breast, as well as his belly, are snow white. The white on his throat extends completely around his neck, which makes one think he is wearing a high, stiff collar. There is a broad belt of blue gray which extends completely across the breast from the butt of the wings downward about two inches, which at a distance gives the appearance of a black hand. The feathers on the head stick up like the hair on the head of a ten-year-old boy. His feet are very small, not much larger than those of a sparrow, yet they are large enough for him to use in scratching away the dirt when making a nest hole and to enable him to sit on a limb. As he never tries to walk or hop, he has no use for better feet and legs. Some of the foreign kingfishers are brilliant in color, some even being a bright green, but their habits are much the same. They love nothing so much as solitude and a good clear stream of water in 


\section{KNOWING BIRDS THROUGH STORIES}

which is an abundance of minnows, tho a few varieties live in the forest far from water and eat insects. Even there they are contented to be wholly alone. They live in pairs only during the nesting season.

\section{Key to the Families of Coccyges}

\section{AlCEDINIDA-Kingfishers.}

With 3 toes in front and 1 behiad.

Cucuride-Cuckoos.

With 2 toes in front and 2 behind, but with the anterior toes separated to their bases.

TrogonIDE-Trogons.

With 2 toes in front and 2 behind, but with the anterior toes united for their basal half. 


\section{$\mathbf{X X I V}_{\mathrm{j}}$}

\section{PICUS THE FLICKER}

TTHEN I built my house in the vicinity of Nashville, Tennessee, I selected a site at the foot of a hill in a beautiful grove at some distance from the pike, where the birds could live their natural lives undisturbed by passing vehicles. The family moved into the house in the fall. One morning the next February we were wakened by a tremendous drumming on an old tin can. My good wife aroused at once and asked what was making all that racket. We listened a few moments and it came again, a perfect tattoo of drumming. My reply was that spring was opening and evidently some woodpecker was out hunting for a wife. We peeked out of the window and sure enough a gallant young flicker sat on an old five gallon tin can some one had dropped about two or three hundred feet away on the side of the hill.

The flicker is one of the most widely distributed and best known of woodpeckers. It is about the size of a meadow lark or a robin, and the Eastern forms are easily recognized from most other woodpeckers by the fact that their wing and tail feathers have yellow shafts and are shaded yellowish, which gives them more or less of a golden appearance when they fly; and from the fact that they are spotted and speckled with black while the general color 


\section{KNOWING BIRDS THROUGH STORIES}

of the upper parts of the body is a golden brown with a white rump. There is a red streak on the back of the head, and the belly is whitish, spotted, and marked with black.

They are jolly, saucy fellows, flitting about, chasing each other from tree to tree, and giving utterance to a "whickety, whickety, whickety, whick." Then one will call "Keeler" once or twice, and away he goes to another tree. You can recognize a woodpecker from any other bird from the fact that he perches on the side of trees and large limbs, uses his tail for a prop, and every little while pecks the wood. The bill is strong and sharp so that it cuts the wood easily. The head is rather large and the neck strong, which gives great power for pecking. The tongue is sharp, pointed, and barbed so that it can easily be stuck into a hole and made to pierce a grub and draw it out. They peck wood largely in order to get the grubs which are living in it. These grubs are much liked by these birds, are a welcome addition to their food in winter, and together with ants and bugs are the principal food in summer. I have never been able to decide just how a woodpecker knows where a grub is located, but I do know that they do not peck wood just anywhere but in some way locate a grub before they begin pecking. On the other hand they tap here and there, possibly listening for a hollow sound before making a hole. Some of the small woodpeckers, however, make a great many holes in trees, pecking just deeply enough to draw the sap. We are told that they drink the sap as it oozes out, but this is not their only reason for wishing the sap to run. They learned long ago how to sugar for insects.

When I am collecting moths, butterflies, and other insects I sometimes mix a preparation of sugar sirup and 
fruit juice and put it on the bark of a tree here and there. After a few hours I go back to the trees to see what is feeding it. When the insects have had time to find it, I am quite sure to discover many insects every time I make my rounds. Of course most of them are just ordinary varieties that $I$ do not care for, but sooner or later I find something worth while.

Now Mr. Sapsucker's feet and legs are not formed so as to permit him to go into the meadow and catch insects like a mocking bird or a robin, and yet he must live. Therefore he pecks holes in limbs and then comes back from time to time and feeds on the insects the sap has attracted. He knows full well when the sap will flow in the various trees and does very little drilling when the sap is not running. However, I must not spend too much time on woodpeckers in general but must get back to Picus.

Picus continued his drumming on the old tin can at intervals during the day, and early the second morning we were again wakened by his tattoo. Evidently there was a flicker maiden somewhere in the woods who heard and came to see what sort of gentleman it was that could drum so much louder and make so much more wonderful music than any of the young gentlemen of her acquaintance. Surely a bird which could peck like that ought to be able to provide grubs in abundance for a family. At any rate when I peeped out the second morning to see Picus drum, I saw this maiden alight on a limb just above his drum. Here she danced about in the characteristic flicker manner and attracted the attention of Picus, busily engaged as he was in beating his drum. Clearly it was a case of love at first sight on his part for he immediately left the ' can and alighted on the limb not six inches from her 
side. Then began a series of acting that was so human as to be amusing. The young lady looked up as if perfectly surprized, as much as to say, "Where did you come from? I did not suppose there was a young gentleman in all the woods." He bowed and whicked, "How do you do?" She promptly flew away to the next tree, wishing to have it distinctly understood that she did not talk to strange young gentlemen.

Picus sat still for a few minutes, craning his neck to see where she went, and then flew to the limb just above her, precisely as she hoped and expected he would do. He did not make his advances so boldly this time, but danced about the limb, examining it on all sides very carefully for a worm, while she sat demurely on her branch totally oblivious of his presence. When he became satisfied he was getting nowhere by dancing about on his limb he hopped down beside his lady love and began to whick, "Fine day this morning." More insulted than ever, away she flew; but while there were a thousand acres of trees to which she might have gone she flew only fifty or sixty feet.

This went on for perhaps an hour, when another gentleman flicker appeared on the scene and began to press his suit. To an outside observer it was evident from the first that this young lady had her heart set on Picus, but it was far from her to let him discover this as yet. Accordingly she received the attentions of the new arrival with apparent favor and allowed him to alight on the limb beside her and together they danced round and round the limb, whickety, whickety, whicketying as friendly as could be. Poor Picus did not seem to feel that matters had gone far enough for him to have any particular rights in the matter so away he went back to his can and began 
to drum lustily. And would you believe it, as soon as he had left the red oak tree this flicker maiden pounced on his rival and drove him away and then deliberately flew back to her perch above Picus and his drum! Of course she wasn't interested in Picus, but there might happen to be a fat grub in this tree!

In due time Picus saw her and the performance started over again. By noon the third day things were beginning to be interesting. When the courtship was at its height I saw at one time six flickers-Picus, his lady love, and four other suitors-on a large dead limb in the top of a giant oak tree. If you had been there and watched their actions without having followed the romance for the past two days I am sure you never would have been able to tell which of the suitors she favored.

I was not present when the matter was finally settled, but on the morning of the fourth day when Picus played bis morning tune on the tin drum, the young lady alighted on a tree near by, but she did not fly away when he alighted by her and began love making. Instead they nodded and chatted as friendly as could be, and then flew together to the dead limb in the top of the great red oak tree and began looking it over very carefully-for what purpose I was not quite sure. This time when some of her less fortunate suitors appeared, Picus did not hesitate to let them know how matters stood, and his lady love, with all her love for flirting, soon made it evident that their presence was no longer welcome. When I came home to dinner that day a new hole had been pecked more than an inch deep in the side of a limb in the great oak.

For nearly two weeks these woodpeckers played, hunted, made love, and worked at their nest by turns. Judging 
from the pieces of wood they threw out, they must have made their nest hole at least twelve or fourteen inches deep. It was too high and too dangerous for me to attempt to climb to it, but judging from many similar flicker nests I have seen, it went into the side of the limb an inch or so and then turned and ran downward. The hole in the side of the limb was just large enough to admit a bird nicely but was much larger inside, roomy enough, in fact, to house both birds nicely, or even to hold a half dozen full grown birds without overcrowding. The bottom was rounded out a bit and a few feathers may have been carried in, or they may have neglected this unnecessary work. Before the middle of March the eggs were laid; perfectly round eggs as white as alabaster and so transparent that if you held one up to the light you could see the yolk plainly through the shell.

While the nest building was going on Picus never failed to beat his drum every morning, and his good wife never failed to show her pride in the fact that he was the most powerful musician in all the woods. Evidently the greatest feat a woodpecker can perform is to beat a long, loud, rolling tattoo on his drum. Every male flicker, and every male red-headed woodpecker for that matter, selects a drumming place early in the spring and there he drums every day through the breeding season. He will search for hours and even days to find a place that is resonant; if at any time during the summer he chances to find a place where he can make more noise, he promptly forsakes the first for it.

As the boards on the comb of a house or barn are apt to be the best sounding boards in the neighborhood woodpeckers often choose these places for their morning song. 
I remember very well on the old farm it was always a race between the chimney swift and the woodpecker on the comb of the house to see who would have the honor of wakening the family. I have known a woodpecker to find a weather board that was loose enough to rattle well and peck on it until he had pecked a hole through the side of the house. At one time the tin that fitted around our chimney became loose on one side. A red-headed woodpecker discovered this and for several days he was in the greatest glee. Father put a ladder against the side of the house, gave me a hammer and some nails, and sent me to the roof to nail this tin down tightly. The next morning Mr. Redhead was much chagrined when he brought his wife to listen to his wonderful musical powers, only to discover that his drum would not work. He tried it a few times and then flew away in disgust and thereafter did his drumming on the barn.

As a boy it was always a mystery to me how such birds as flickers managed to get their young out of their hole. The hole where Picus lived faced directly toward our front porch, and my field glasses made it appear only a few feet away. When the young birds were nearly grown they began to get restless and made a good deal of noise whenever the parents came to the nest hole. Soon I began to notice an occasional head peeping out of the hole, looking at the great world outside. In a day or two the young birds did not hesitate to sit in the hole, and finally to creep outside clinging to the limb with their claws and bracing themselves with their tails. Evidently the young begin using their claws to crawl about in the nest hole and so soon as the tail feathers are well grown are able to crawl about on the outside. If you will notice a woodpecker 


\section{KNOWING BIRDS THROUGH STORIES}

when he is creeping about on the trunk of a tree, you will see that he uses his tail as a prop. It is doubtful if he could climb about a tree as he does if his tail were pulled out. When you get a chance, examine a tail feather from a woodpecker and I am sure you will be surprized at its stiffness. It was two or three days after the first young bird was out of the nest before I saw any of them fly. For weeks they were most often seen feeding on the ground. Woodpeckers and especially flickers live largely on ants and beetles, and these are easiest to find on the ground.

Picus' young flickers left the nest hole soon after they were able to fly and, as the summer was dry and food scarce, soon found their way to the barn and cornfield. They eat corn and other grain when short of food, and are especially fond of roasting ears, pecking the end of the ear and tearing the husks to shreds to get at the grain. At husking time farmers often find ears of corn the tips of which have been eaten by flickers.

Picus and his wife reared two broods of young in their nest hole and then were forcibly driven out by an old gray squirrel. There is no creature more light-hearted or goodnatured than the flicker. Picus never missed his drumming a single morning because he had lost his home, neither did he quarrel or fight with the squirrel. He merely moved with his wife to the barn, and went on with his normal life. Practically every day they visited the old home tree and early the next spring made a new hole on the other side of the tree. There they were keeping house contentedly when I moved away and there they may still be living for all I know. 


\section{XXV.}

\section{A' STRANGE NEST}

NE day Orvil Greeson and I started to the river to go fishing. Boylike we cut across fields and soon found ourselves in a large cornfield. Then Orvil said to me, "Let us go over to the bird's nest I found yesterday while plowing." No one ever saw a boy who wasn't interested in a bird's nest, especially if it be in such an unusual place as a cornfield, and so of course we went over. Near the middle of the field in a small clump of bushes he pointed to two whitish eggs lying on the ground without any indications of a nest. Now mother had taught me that we ought not to rob birds' nests, so the first thing I said was, "Why did you rob the nest?" His answer was, "I did not." "But," I said, "there's no nest there. Where did these eggs come from ?" "The old bird laid them right there," he said, and we had quite a discussion as to what sort of bird it was. Orvil said that when he was plowing corn the day before a queer looking gray bird flew up in front of his team and fluttered about so much that he stopped to see what was the matter. Of course the bird got away, but Orvil saw the eggs. He was not well enough acquainted with the bird to know it, so when I went home I asked mother what it was. She said it was a whippoorwill, but that their eggs are usually slightly speckled. We did not have 


\section{KNOWING BIRDS THROUGHI STORIES}

many whippoorwills in our neighborhood and it was only when we went over to the river that we heard them whistle.

Of course I was interested and would have liked to watch till the eggs hatched and the birds grew up. But as it was two or three miles from home and the garden needed hoeing, and when there was time to play there were so many things worth investigating near by, I did not get back to the nest. Orvil and I did not go to the same school so I never asked him whether he watched the young birds hatch and grow up or not; but I have always been glad I saw this whippoorwill's nest, for I have never found another in just that kind of place.

When the birds were learning to build their nests, evidently the whippoorwill had a lazy fit, for she does not build. She simply selects a spot on the ground, in the brush or woods or in some similar out-of-the-way place, and lays her eggs without even the trouble of wallowing a hole in the ground. They are sometimes laid even on top of a dead leaf or on the grass. I presume the reason why she lays her eggs on the ground is that the ground is so nearly her own color that there she can feel safe from being caught while brooding. A whippoorwill does not fly in the broad daylight. I do not know whether she sees well in the daytime or not, but I am inclined to think the light dazzles her eyes much as it dazzles the eyes of an owl. She depends almost entirely on her color for protection.

When I was about ten years old, two or three of us started up to the head of Wymore's Branch to gather dog'stooth violets and Dutchman's breeches. After we had all become tired, we clambered on the top of a rail fence 
to rest. We had been sitting there talking for some time when I happened to put my hand down on the rail on which I was sitting, and just for the fraction of a second a knot on the rail moved slightly and then settled back as quietly as before. But this one movement, slight as it was, was enough to catch my eye, and I could see that the object was not a knot but a bird. Clearly the bird felt that she had made a mistake in moving, but still believed she had not been detected. At any rate she allowed me very slowly to move my hand closer until with a grab I caught her. It was a whip-poor-will. Several times since I have caught whippoorwills in just that way; but at the time this was wholly new to me, and was my first experience with animals depending for protection on being the same color as the surrounding objects.

I had several surprizes when I came to examine my bird. Her body was about the size of a robin. In color she was a queer mottling of dull brownish, blackish, and gray white-just the colors we see on our dead and decaying wood. Her feet and legs were small and poorly developed. I am sure they would have been of little use in walking, but this is of little importance to the whippoorwill, for she does little of that. When I spread her wings I met another surprize-they were so long and well developed. I could scarcely believe so small a bird could have such long wings. In fact, they were so long they appeared very slender, tho really they were about as broad as the wings of some other bird of the same size.

Many an evening I had seen whippoorwills flit about near the ground over pastures and fields from an hour or so before sunset till dark, and had been told that they were catching insects. In fact, father had told me that in- 
sects were their only food and that they fly in the evening because at that time most of the winged insects are in the air. I expected to find a bird with a large, wide bill, and so looked at my whippoorwill's head very carefully. The head was broad and rather large, but to my utter surprize the bill seemed little larger than a large grain of wheat. There were a lot of bristle-like hairs growing at the base of the bill which made her look still more queer. I remarked to one of the boys that I had never seen so large a bird with so small a bill, and then, as I had been used to feeding birds that way, I pulled her mouth open and there came my greatest surprize. It opened clear down almost to the base of her head. It looked as tho she could easily swallow something much larger than her own head, for her mouth seemed to open half way down her throat. Then I understood how she could catch and swallow June bugs and other large beetles.

The whippoorwill belongs to the Caprimulgidæ family, of which a great many varieties exist, but only a few live in the United States. They are commonly called goatsuckers-I suppose because the mouth is so big that people used to think that they drew milk from goats.

We have four principal varieties of goatsuckers in this country and a few lesser varieties exist also. Three are generally known in the United States. The one most common is the nighthawk. Throughout the summer over a great part of the United States this bird is seen flying about over fields and meadows nearly every afternoon and evening, and many people mistakenly call it a whippoorwill. The nighthawk differs from the whippoorwill in that it is larger and flies well up in the air, while both the whippoorwill and the chuck-will's-widow 
(the third common variety) seldom fly more than fifteen or twenty feet high. The nighthawk has long slender wings ani a rapid flight. As he flies over us we can easily distinguish a white half moon on the under side of the wings. This bird is accustomed to make a dive sidewise or downward for an insect, when the rush of the air through the wing feathers produces a sort of half groan and half grunt, which is loud enough to be heard several hundred feet away. At such times he is probably darting after prey.

Nighthawks are common along the Atlantic coast and have been observed to follow boats several miles out to sea. Their main food is June bugs, grasshoppers, and the like. The nighthawk has no song. In color it is somewhat similar to the whippoorwill. The mother bird builds no nest but lays her eggs either on the bare ground or on on a bare flat rock about one hundred and fifty yards from my house. She selected a rock that was about her a bare flat rock. In 1921 a nighthawk raised her family own color and there she would sit even tho we came within eight or ten feet of her.

One spring I was visiting a Mr. Louie Schmidt near Bonaparte, Iowa. He lived on a farm not far from the Des Moines River, and as there was considerable brush and timber on the place the whippoorwills were abundant. One night when the moon was full and the whippoorwills were whistling on every hand, we decided to try to see a bird as he whistled. We crept across the pasture to the border of a field full of hazel brush till we stopped within twenty feet of where the bird was, and there I saw something for the first and only time-a whippoorwill lying flat on his side in an open place in the brush whis- 


\section{KNOWING BIRDS THROUGH STORIES}

tling, whippoorwill, whippoorwill, whippoorwill, as fast as he could. He seemed to feel that there was only one thing worth doing in all the world and that was to see how many times he could whistle whippoorwill in a minute. We watched him for at least a half hour and he never once paused for breath. This whistling without a stop or break is a characteristic of the true whippoorwill and becomes very tiresome after a time.

Usually whippoorwills sit on the top of a house or on a cattle shed or some similar place to sing, and they keep up their song from dark till dawn.

The chuck-will's-widow and the poorwill are the only birds that could be mistaken for a whippoorwill. Their habits are very similar to the whippoorwill's, but the birds differ in song, size, and details of coloration. 


\section{XXVI}

\section{THE CHIMNEY SWIFT.}

7 HE house on the old homestead was a two-story one,

1 or rather what nowadays would be called a storyand-a-half, which means that the upstairs rooms were rather low and near the roof. We boys slept in those upstairs rooms, and the chimney was only a few feet from the head of my bed. Usually I thonght little about the chimney, except to appreciate it on cold nights. But in the summer-time on Sabbath mornings, and on other mornings when we were allowed to sleep an extra hour, this chimney was a nuisance. With the first break of dawn the trouble began. Suddenly we would hear a rattling twitter, then a rumbling noise as tho something were being poured into an empty barrel, and then such a squeaking as would waken even a tired growing boy. No sooner would it stop and one would turn over, feeling that now he was going to get a little quiet, than the whole performance would be repeated. As the morning progressed, the noise became so persistent that it was impossible to sleep. And what do you suppose caused it all?

When the first settlers came to America, among other interesting things they found a small greenish black bird with slender wings and with feet so poorly developed that it very seldom attempts to alight. This bird was in the habit of building its nest in tall hollow snags or trees. 
Like the Colorado potato beetle and the American cabbagebutterfly, it was wise enough to profit by the coming of the white man; for no sooner had the settlers begun to build chimneys than some bird wiser or more curious than her neighbors proceeded to look the situation over. Whirling in ever narrowing circles over this strange hollow stone tree she doubtless was attracted by its comfortable warmth and by the fact that it would be secure from owls, snakes, and other marauders. Doubtless after long and earnest discussion with her mate she made the experiment of sticking her nest to the inside wall of this chimney.

The chimney swift, for that is the name of this bird, was a very careful housewife, and suceeded in raising a family of lusty youngsters, every one of which, we can imagine, sought out a chimney as its nesting place when old enough to build a home of its own. Their neighbors and companions were not long in following the example, so that long since they have forsaken entirely the ways of their forefathers, and there is hardly a tall chimney in the land over the regions where Mrs. Swift and her tribe spend the summer that does not contain from one to a dozen nests. They do not usually nest in low chimneys on onestory houses if they can find others. Some staid oldfashioned swifts stuck to the old paths for a long time, however, and even yet one occasionally finds a tall hollow sycamore tree-the favorite nesting place of the swifts for a thousand generations, possibly because its bark is too smooth for snakes to climb-in which these birds are nesting.

Mrs. Swift belongs to rather a small family, of which we have only three other members in this country. Swifts 
are remarkable birds not only because they spend a large part of the day on the wing, never alighting on trees and very seldom on the ground; but also from the wonderful way in which they build their nests. At nesting time these birds secrete a sticky gelatin-like saliva which they smear on the inside of a chimney and allow to dry. Our chimney swift brings small sticks, which she glues fast to this mass, and little by little, she adds more glue and more sticks until the nest is finished.

It is interesting to watch these birds gathering sticks for a nest. They select a tree whose twigs are dead but still tough. About such a tree near our house one could see swifts circling in great numbers, as they came both from our house and from our nearest neighbor's. Suddenly a bird would dash at a twig, catch it in its feet, and make a peculiar sidewise jerk which snapped it off short. Away the bird dashed to the nest, carrying the stick in its feet. It seems strange for a bird with such poorly developed feet to carry its sticks in this way, when most birds carry them in their bills.

The nest of our chimney swift is made about half and half of this bird-glue or gelatin and sticks. In Southeastern Asia and the East Indies one of her cousins uses no sticks at all, but plasters on the glue little by little until the entire nest is made of it. The natives have learned to collect these birds' nests and make them into soup, of which they are very fond. People who have eaten bird's-nest soup tell me that it really is fine. In fact, bird's-nest soup is so delicious and the nests are so hard to get that there are few articles of food there that command a higher price.

I have never known any one to attempt to make soup 


\section{KNOWING BIRDS THROUGH STORIES}

from the nests of our chimney swift, and I do not think it would serve that purpose well. Even if all the sticks were strained out, so much smoke and soot settles on the nest as it is drying that I am sure it would taste more like soot soup than like bird's-nest soup.

The nests are usually built several feet from the top of the chimney, and are almost flat on the side that touches the chimney. In fact, they look very much like half nests stuck against the bricks.

No one need have trouble in recognizing the chimney swift, for it is the only bird that enters, much less nests, in chimneys. A little observation will make it easy to recognize this bird even in the air, for the only birds that much resemble it in flight are the martins and swallows, and all of these that are found in the neighborhood of a house appear considerably larger than Mr. and Mrs. Swift.

As a child I wondered how Mrs. Swift managed to get her youngsters out of their nest. Usually some morning after the birds had been exceptionally noisy and annoying the noise would cease, and going out into the yard we would find the family sitting on the edge of the chimney top or on the comb of the roof. It was never more than two or three hours till they were flying about apparently as active as their parents, and we were not able to tell which were the young, except when the old birds fed them. This they do for two or three weeks after they can fly, feeding them while in full flight in mid-air. When feeding, both birds remain practically still in the air, hovering much as a humming bird does in front of a flower.

Almost every summer some over-ambitious bird would jump out of the nest before he was able to get to the top of the chimney and then we would hear his cries of dis- 
tress far down at the bottom of the chimney. Many times I have opened the hole at the foot of the chimney and taken these young birds out, but I was never able to raise one. They refused to eat grasshoppers and crickets, and I was not able to catch gnats and flies for them as their mother had done. In fact, the mother feeds her young largely on ants for the first few days, and then gives them partly digested insects from her crop till they are nearly grown. Perhaps they died under my care because they had been hurt in falling or it might have been because they had been used to the warmth of the chimney. If the young bird is not hurt by the fall it may climb back into the nest. These birds have very strong sharp claws and a stiff tail. The old birds roost at night with their claws stuck into the side of a brick, and their tails act as props to hold them in place. Audubon tells us that the fledgling, if his tail has grown out, can hold in this way and climb up the side of the chimney to his nest.

One afternoon at school one of the boys whispered the startling news to me that the chimney swifts were on the ground out by the old cinder pile and that they were so gentle one could get within fifteen or twenty feet of them before they would fly. He had been out of doors and was all excited over his discovery. I offered some excuse for leaving the room and sure enough there were half a dozen swifts hopping about on the cinders, chirping. It certainly was amusing to see them attempt to walk. In fact, one could hardly give the name of walking to their peculiar half-hitching gait. I had always supposed the swift to be black, but now I discovered he was a brownish black with a green gloss over his head and back. The lower parts are grayish brown, sometimes slightly tinged 
with green; the throat is dull white, and there is a lighter gray line over each eye. His very long wings lie back so far as to give him the air of a real aristocrat.

In the autumn, when the nights begin to get cool, the swifts begin to show anxiety. They can be seen perching on the roof or even sitting about on the ground. Finally some morning we notice that they are gone. They do not leave one at a time, but all that are nesting in any particular farmstead go together. One afternoon in the fall at Madison, Tennessee, I saw a large number of chimney swifts flying about over the school premises. They acted as tho perfectly at home, darting back and forth catching insects. This was a great surprize to me, for I have known only a few pairs to nest on this place. About sundown I noticed that they were circling about a large old chimney stack. Sometimes they would leave the region of this chimney for several minutes, and then would come back and circle about it again. Just as the sun was sinking below the horizon one more daring than the rest darted down the chimney, and in less time than it takes to write it there was not a bird in sight. All of them passed the night in this chimney, flew about over the place for two or three hours in the morning, catching their breakfasts, and then departed. It is not uncommon for migrating chimney swifts to stop in this way and rest. In the fall of 1921 hundreds of them roosted every night for ten days or more in the tall chimneys of our heating plant, and some birds remained all day.

In the spring they do not appear to come back one at a time, tho it is often reported that they do so. All the swifts in our neighborhood usually came back together. I remember one day we boys were out on the school grounds 


\section{THE CHIMNEY SWIFT:}

playing ball when suddenly the chimney swifts began to fly around the house. In and out of the chimney they chased each other, evidently in the greatest glee to find themselves at home again. Pretty soon we discovered more passing overhead, and when I got home that evening the first sight that greeted my eyes was the chimney swifts darting in and out of our chimney. The next morning every boy in the school reported the same thing at his home, and all agreed that they must have arrived at every house in the district within a few minutes. Whatever you may do with other birds, allow no one to kill the chimney swift, for he feeds entirely on insects such as mosquitoes, gnats, flies, and ants, and he catches most of them near the house, just the place where they do the greatest harm. 


\section{XXVII}

\section{RUBYTHROAT}

TN the northwest corner of our yard stood a clump of 1 Blue Damson plum trees. They had not always been Blue Damson plums. Father had set out only one tree and it was supposed to be a large blue plum. This tree never ripened any fruit because of the plum curculio. You can read the story of this in "Knowing Insects Through Stories." Finally this tree died or was broken down. In its stead a number of sprouts came up, grew vigorously, and within two or three years were bearing. We could not know whether they were like the parent tree or not until they were large enough to bear, and as plum trees were expensive in those days all were left to see what they would be. After these bore and proved to be damsons, we cut out the weaker trees and allowed eight or ten of the best to remain.

On one side of these Damson plums stood a clump of hardy hibiscus that died to the ground each winter but came up every spring and made plants six feet or more tall, and for weeks bore a mass of giant white flowers with crimson centers. Growing beside this hibiscus were several clumps of columbine, and ten or fifteen feet away was a coral honeysuckle, while roses grew in profusion all over the yard. It is small wonder that mother and father 
Rubythroat should select this particular corner of the yard for their home. They lived there for several years and may be living there yet for all I know. They certainly were when I left the old home.

Now Mr. and Mrs. Rubythroat were humming birds. Humming birds belong to the Trochilidæ family and are easy to recognize, first, because some of them are the smallest of birds; second, because they are mostly brilliantly colored; and, last but not least, because they vibrate their wings so rapidly that they make a humming sound, a thing that no other bird does. All humming birds are American, but most of them live in tropical America. In the West Indies there are many kinds, but one needs to go to the Amazon basin and to the Andes Mountains to find them in all their glory. Some of these are scarcely larger than bumblebees, while the largest are almost as large as a sparrow. Some of them have very beautiful crests and others long brilliantly colored tails. In spite of these differences they are much alike, and no one who has ever seen one kind would fail to recognize any other as a humming bird, tho he might not know what particular kind it was. East of the Rocky Mountains and north of Texas we never see any humming bird but the rubythroat. He is a beautiful peacock green above with a sheen of gold and bronze when the sunlight flashes on him. His throat is ruby red, hence his name.

Notwithstanding that he is so small, the humming bird is a bold, active bird, and at least one kind nests during the short summer season in the southern part of Alaska. In California, New Mexico, and Arizona there are about fourteen different kinds to be found; but as Mr. Rubythroat is found over more territory than any of the others 
we tell his story. He is found practically all over the Eastern United States and Southeastern Canada, so you will have no trouble in locating him.

The first I remember seeing Mr. and Mrs. Rubythroat was on a day early in May when I was about five years old. I was playing in the front yard when I heard a peculiar humming, and looking up saw a bird literally standing in the air not three feet away and staring into my face. His wings moved so fast I could hardly see them, yet he stood perfectly still. Finally his curiosity being satisfied, he gave a little squeek, whirled over the house, circled around a time or two and came back to the Yellow Harrison rose bush that was just opening its first blooms. I remember watching with great interest as he went from one rose to another, pushing his sharp bill in among the stamens and pistils and licking up insects, pollen, and possibly nectar. Finally he flew to a clump of bluebells that were still in bloom and proceeded to suck nectar from them.

I determined to watch these birds and find their nest. It seemed to me that birds so small as they would build a veritable fairy nest, and I was anxious to see how they would go about it and also to see their eggs. I saw these birds every day and almost every hour in the day for weeks and felt sure that their nesting place was either in one of the plum trees or in a Norway spruce hard by; but for all my watching I could not find it. These birds nested in our yard every year from that time until I was sixteen years old and left home to enter college. I do not believe there was a single summer in all that time that I did not spend hours hunting for their nest. I felt perfectly sure that they built in that part of the yard; and 
after the Blue Damson trees got large enough to bear I even thought I knew that the nest was in one of these trees, but I never discovered it.

I have spent many a Sabbath afternoon sitting under these trees with a book or paper, determined to watch until I saw those birds go to their nest. Every time I heard a whir I looked up, but the birds were more shrewd than $I$.

The young birds appeared regularly at the proper time, and I knew their family life well, but they were so expert at hiding their nest that they baffled all my family. I saw humming birds' nests at some of the neighbors', however. The first one I remember seeing was in Dan Davis' yard in a giant white elm tree too large to climb. Tho this nest was scarcely more than an inch and a half in diameter it was built on the top of a limb as thick through as a man's body. It was made of horsehair, thistle down, and feathers, stuck into a crack in the rough bark, and covered with lichens glued on with the bird's saliva. This tree stood on a sidehill where we could see the nest and even get close enough to know what was going on in it, but we could not get at it. After the young birds had flown, some of the boys put a ladder against this tree and took the nest down, and we tore it up to see how it was made.

$\mathrm{My}$ birds of the plum trees were great fighters. I suppose there is not a bird that lives that is more aggressive than the humming bird. He is always on the lookout for any bird that might possibly do his mate or his nest harm. If he does not find such a one, he will fight anyway if he can meet an opponent. He is the one bird with which I am acquainted that does not hesitate to attack the kingbird 
or the martin. In fact he seems to have a special grudge against those two birds, and my rubythroats would not allow the kingbirds to come into that part of the yard at all. If perchance Jerry happened to venture into his domain, before he knew it Mr. Rubythroat was upon him. Quicker than a flash he would strike with his sharp bill again and again. His tactics were even more aggressive than those of the kingbird himself; and since he was so small and so very active, Jerry had a bitter taste of the medicine he so delighted to give Jim Crow and the old brown tailed chicken hawk. When I was among the plum trees my birds were very uneasy indeed, flashing about my head and squeaking but never daring to strike. Sometimes they would alight within two or three feet of me and squeak and fuss, all of which led me to think that the nest was close.

Since I have been grown I have had the privilege of watching humming birds build their nests. The ordinary nest of this bird is built of down and soft vegetable substances and is covered on the outside with lichens. I have known of but one nest that contained hairs. These lichens are carefully picked from the limbs of trees and match their surroundings so well that the nest is hard to find. I am quite sure now that my humming birds nested for several years on a half dead limb on one of the plum trees that was covered for several feet with a growth of lichens. I never dared climb this limb for fear it would break, and evidently my eye could not distinguish between the lichens which covered the nest and those growing on the limb. Another thing that makes a humming bird's nest so difficult to find is the fact that the bird rises high in the air when she starts to her nest and when she 
reaches the spot, seems to drop upon the nest from nowhere like a bolt out of the sky.

The humming bird lays only two eggs. They are white and scarcely larger than a small navy bean. The bird sits usually fourteen to fifteen days. When the young are hatched, they are as helpless looking little creatures as one could imagine. They are scarcely as large as a tumblebug and as naked as a young mouse. They are so weak and frail that they can scarcely raise their heads for food. The mother is exceedingly careful of them, hovering them solicitously for two or three days. She feeds them by sticking her bill down their throats. When the young are half grown she begins feeding them freshly caught insects. Within sixteen days they are ready to leave the nest and fly. Think of it, a perfectly naked bird growing to maturity, putting on the brilliant plumage of a humming bird, and becoming ready to leave the nest and meet the cares and dangers of the big broad world all within sixteen days! Within three or four days the mother lays two more eggs. During this time the young humming birds have been taught to find the sweetest flowers and to catch the choicest insects, and then they are left to shift for themselves. They quickly leave the vicinity of the nest, and usually all of the young humming birds in the neighborhood collect together, either for the fun of racing with each other or because they feel more secure because of their numbers. I have seen in our yard as many as eight or ten young humming birds in one flock dashing after one another over the lawn and into the rose bushes and columbines till tired out, and then they would finally settle to rest on the branches of a tree.

The young, and for that matter the mother bird, do not. 


\section{KNOWING BIRDS THROUGH STORIES}

have the ruby throat. The young males have the throat whitish finely streaked with dusky, taking on the brighter color much later. The humming bird feeds largely on small insects that gather in tubular flowers. He has a partly tubular tongue which enables him to extract these insects readily and also any nectar which may be in a tube of the flower.

But these birds do not depend on flowers alone for their food. I have seen them "stand" for two or three minutes at a time in front of a branch on a box elder tree and lick the aphids off of the leaves with their long sticky tongues. I am sure most of you have seen gnats, mosquitoes, or other small insects flying in swarms of a summer afternoon The humming bird delights to find such a swarm. He darts back and forth through it catching insects until, tired out, he has to perch and rest, only to return to the chase in a few moments if the insects are still in sight.

Mother Humming Bird usually raises two broods in a summer. Mr. Humming Bird seldom alights, but when he does the first thing he begins to do is to primp. He will take a few steps sidewise, crane his neck, ruffle his feathers, lift first one wing and then the other and finally begin to run each quill feather in his wings separately through his bill. It takes quite a while to attend to this, but he goes through the performance perhaps a dozen or fifteen times a day.

If two strange humming birds happen to meet, there is almost sure to be a hard battle. The first humming birds I ever caught were two which were fighting so fiercely that they fell to the ground and failed to notice me until I had my hat over them. It is said that animals which have 
never developed patience by bringing up a slow growing family are always high tempered. Evidently this is true of the humming bird. The young grow up very quickly, and surely none are more high tempered and more ready to fight.

A friend of mine one day found a humming bird that had in some way injured its wing and could not fly. He made a splint out of a piece of match straw, carefully bound up the wing and fed the bird on sugar sirup with an occasional small gnat or beetle. In a very few days the bird was able to fly, but by this time it had become so tame that it did not care to leave the house. It would sit on the back of a chair or fly about the room for hours at a time. Its wing was not very strong, so it was not able to make long flights or to remain in the air long at a time. He used to fill an old fashioned fountain-pen filler with thin sugar sirup and hold it up for Mr. Rubythroat, who would come and thrust his bill into the end of the glass tube and suck up the sirup. My friend being somewhat of a musician, and having a scientific turn of mind decided one day that he would like to know just how many times Mr. Humming Bird moved his wings in a second when he was hovering before the fountain pen filler sipping sirup. Accordingly he took his violin and picked out the tone that exactly harmonized with the hum of Rubythroat's wings. The tone was " $A$ " below middle " $C$ " and as it takes two hundred-fourteen vibrations per second to produce this tone this tiny little bird actually fluttered his wings two hundred and fourteen times a second. It seems almost impossible that so small a bird can generate energy enough to do this enormous amount 


\section{KNOWING BIRDS THROUGH STORIES}

of work for hours every day; but any one who has seen a cross old bumblebee attack a humming bird that has crowded him out of a flower knows that he simply makes sport of the bee's anger, tantalizing him in much the same way that a jack rabbit on the western plains will tantalize a farm dog, keeping just far enough ahead to cause it to exert itself to the limit and, when he has had sport enough, darting away like a flash.

Sugar is suitable for furnishing a large amount of heat and energy to such things as bees and humming birds that have power to digest it; but even they can not live on this alone. My friend's bird in about three or four weeks began to grow droopy and showed clearly that he was not well in spite of the fact he was fed a few insects. Finally he was taken out of doors and allowed to fly to the honeysuckle vine and the jimson weed flowers where he caught an abundance of insects and doubtless ate pollen, and soon he became all right again.

When the autumn days came the great spirit that guides the feathered folk whispered in his ear one evening that it was time to fly away to the sunny land of flowers beyond the seas. He was well then, and had been active all day; but he was seen for the last time only an hour before sundown. The next morning he was nowhere to be found. I am sure humming birds migrate at night, for they are always gone some morning after being active all day. Rubythroat never came back again unless he was the bird who nested the next year on the branch of the Norway spruce in my friend's yard. We could not be quite sure , whether this was true or not, for this bird, while tamer than any other wild humming bird I have ever seen, was yet too wild to allow any one to handle him, while it had 
been Rubythroat's delight to perch on one's fingers to preen his feathers. Humming birds are very easy to tame. Almost as soon as they have been fed they lose all fear, recognizing that only a friend would furnish them such wonderful nectar as sugar sirup. This is best made by diluting sugar with ten or twelve times its bulk of water. All that is necessary is to put it in a cup and allow the bird to get a taste of it by carefully placing his bill in the sirup. He drinks greedily, if hungry, often plunging his bill and head in the sirup up to his eyes.

The Rufous humming bird is about as large as the Rubythroat. It is he that is found in Southern Alaska. I have never been in this region, but I have seen these birds in the vicinity of Bellingham, Washington, and Portland, Oregon. We have some fourteen varieties of humming birds in California and the Southwest. As before stated the members of the family are easily recognized by their small size and by the humming of their wings, even tho one should not catch them and examine the partly tubular tongue and the long pointed bill. Tho the humming bird appears to be very slender, if one should pick off all his feathers he would be surprized to find what a plump muscular little fellow he is. The breast is especially plump and well developed.

\section{Key to the Families of Macrochires}

TROCHILIDE-Humming birds.

With the bill long and slender, the gape narrow, and wing with only 6 secondaries.

Micropodid F-Swifts.

Birds of firm plumage, with bill short and broad, gape wide, secondaries more than 6 , and with the claw of middle toe without a comblike edge.

CAPRIMULGIDE-Goatsuckers.

Birds of soft plumage, with middle toe decidedly longer than the 


\section{KNOWING BIRDS THROUGH STORIES}

anterior toes, the claw of the middle toe with a comb-like edge; bill with conspicuous bristles; tail rounded, and the folded wing not reaching to the end of the tail.

Cropderimid-Nighthawks.

Like the CAPRIMUIGIDA, but with the bill lacking conspicuous bristles, the tail forked, and the folded wings reaching to or beyond the end of the tail.

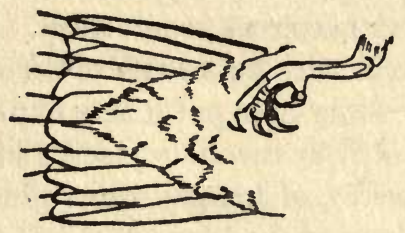

Tail and Foot of Swirt 


\section{XXVIII}

\section{JERRY THE KINGBIRD}

THERE was a Red June apple tree just back of the

1 house that was a favorite with us children. It was different from any other Red June tree I have ever seen. It was larger and thriftier, and grew in as perfect a cone shape as any hard maple. Even when the other trees did not bear, we could find apples on this one, but they ripened four or five days later than on the other trees. They also lasted two or three weeks after the others were gone. In flavor they were identical with that king of early apples, the Red June, but in size were really giants. It was not uncommon to get apples off this tree that were as large as the Ben Davis or the Delicious which we often buy now-a-days on the fruit stand at a high price. In my boyhood days we did not think of price. We helped ourselves to all we could eat and as often as we wished, gave to the neighbors who happened not to have plenty of their own, and even then had abundance to can, to make cider, jelly, or apple butter, and to feed the pigs. I can almost taste those wonderful mellow apples yet! We used to get a dozen or so, peel off the skin, mash them in a dish, mix them with real cream, and have them for breakfast-all one could eat and no one to think we were extravagant. But I must get back to my story. Jerry the kingbird 
evidently had reasons of his own for preferring this Red June. I was never sure what his reasons were, but have always been suspicious that the fact that this tree stood on the edge of the apiary, where there were fifty or a hundred swarms of bees, had something to do with it.

If I remember correctly it was about the first of May, 1883 , that I first met Jerry. I was in the back yard watching the red ants clear a path from their home to a new pasture when I noticed Jerry making love to a shy young bird about his own size and color. It was plain that he was making love to her, for every time she moved he would fly around and around her, fluttering his wings in the most excited manner possible, twittering and chattering all the time. She seemed to pay little heed to him, as is the way of maidens in general, and when he became too persistent in his attentions she flew to another tree. No matter, she hardly had time to alight before there was Jerry close beside her. Sometimes she would fly up into the air in a spiral a hundred or two feet high. Nevertheless there was her insistent lover flying around her and protesting in the loudest tones that he would be the most wonderful husband on earth if only she would consent. I watched them till mother called me to gather the eggs and get in the evening supply of wood. When that work was done, supper had to be eaten and the cows milked, and by that time all honest birds were sleeping.

The next morning, however, there was Jerry making love as insistently as the night before. It was plain to a mere outsider that he had already won his suit, but that his lady fair was not prepared to admit the fact; he, however, was pressing his suit more ardently than ever. For all their love making, both had plenty of time to catch a fly 
if it happened that way. While I watched, a beautiful yellow butterfly came flitting by. Quick as a wink Jerry caught him. Evidently that butterfly was quite a prize, for while in the past each had eaten whatever they caught, Jerry promptly presented his lady love with this butterfly, which she took as a matter of course and swallowed greedily. I had to go about my business and do not know whether the butterfly had anything to do with it, but by afternoon the matter was evidently settled, for I found these birds apparently talking over the best place to set up housekeeping.

I want to say just a word about the kingbird family. Mr. and Mrs. Kingbird are flycatchers, and belong to a large family of flycatchers of which we have a number in the United States. I am telling you the story of the kingbird because he is found in practically every State in the Union and none of the other flycatchers are so widely distributed in the summer, when most people study birds. They are known as flycatchers because many species live almost wholly on flying insects. They are moderately small birds with an alert, nervous appearance. As most species seldom alight on the ground and never scratch, their feet and legs are generally short, altho they have four good strong toes, the hind toe not being much if any longer than the others. Their claws are sharp, moderately strong, and arched, so that they can cling tightly to a limb. In the smaller species the plumage is soft and blending. In many species the bill is more or less triangular and rather wide at the base to make it convenient for catching insects. The tail is usually of moderate length. Many varieties have a topknot and a small red or yellow spot on the top of the head. The male king bird 
is usually a great fighter, especially when his mate is sitting. He perches on a branch over the nest and attacks every bird that comes in sight, and the larger the bird the more certain he is to attack it.

The kingbird is so called because he is such a little terror for fighting other birds. The farmers often call them the bee martin, because in size and appearance when flying he somewhat resembles a martin, and when other food is short he sometimes catches bees. I have often seen Jerry do that, but from my observation I am led to believe that he usually catches drones. I do not mean that if there were no drones and he was hungry he would refuse a perfectly good worker bee, but drones are his preference.

In color the bee martin is a dark bluish gray above, while the head is grayish black crowned with a vermilion spot bordered with yellow. The wings and tail are tipped with white. The breast is gray or sometimes nearly white. The female has an orange crown patch on her head a little smaller than that of the male.

Jerry and his wife decided to build their nest in the very top of my Red June tree. First they selected a number of small dry twigs and placed them as a foundation in the forks of some small branches. Next they went to the sheep pen and gathered wool in abundance and made a thick felt lining for their nest. This evidently was intended to keep it warm and to protect the eggs from anything that might strike the side of the nest. Next they began to take the strings and horsehair that had been put up for the Baltimore orioles' special use and went to a great pile of flax straw and gathered quantities of tow. Of these strings, tow, and horsehair he built a very neat nest inside of the wool lining. I say "he," for Jerry seemed to be 
master of ceremonies in the nest building. His wife helped all she could but Jerry bossed the job.

As soon as the nest was done, the mother bird quietly slipped on while Jerry perched on the very topmost twig of the tree to watch for intruders. Old Jim Crow, who was nesting down by the creek, having decided that grasshoppers should be plentiful in the meadow, started across the orchard to this hunting ground. Before he was nearer than two or three hundred yards, Jerry gave utterance to his sharp tremulous cry, and made straight for Jim. Evidently the crow knew what was coming, for with the first sound of Jerry's voice he began to fly as fast as possible, and dropped down close to the tree tops, hoping to escape notice. Like a fury Jerry was upon him, pecking from above, below, both sides, circling round and round, chattering and scolding, and finally as a climax to his rage alighted on the crow's back between the wings and began pecking and tearing out the feathers. Half a dozen. came fluttering to the earth as proof of the fierceness of the onslaught.

The crow screamed in rage, dashed up and down, back and forth, and in vain attempted to escape; but it was not until he was a full quarter of a mile away that Jerry left him and returned to exult and explain to his wife the great feat he had performed. He had hardly alighted on his lookout when he spied the family cat quietly sitting in the back yard. Here was another possible enemy, and with his shrill challenge he rushed for her. Poor kitty sat up mystified, hardly knowing what to do, when whack he took her in the back of the head. She struck at him with her paw, but before she could think he was out of reach, circling round, striking her again and again. Before many 
moments kitty owned defeat and dashed into the raspberries for protection.

So it went all day long. A hawk could not appear in sight, a crow come nearer than two hundred yards, or even a blue jay come closer than two or three hundred feet without being attacked at sight. For the six or seven years Jerry nested in this tree we never had a chicken caught by a hawk or a crow, and the cats entirely forsook the back yard in the daytime.

One year another kingbird determined to nest in our orchard. He located fully a hundred yards from Jerry's home, but nevertheless Jerry claimed this territory as his own. The two birds were fighting almost constantly for a week. Finally Jerry triumphed, and his defeated rival went to the monstrous Pippin tree in the old orchard, a quarter of a mile away. Probably he was glad afterward that he moved for he found himself within a hundred yards of the migrant shrike's nest and the shrike was following his custom of sticking insects on thorns. The kingbird was not long in finding this out, and it was a favorite pastime of his to collect every insect he found sticking on the thorns.

Tho Jerry would never tolerate another kingbird's nesting in what he considered his own private ground, no bird was more careful in the protection of his mate and of his young. He left his lookout during the period in which his mate was sitting only when he felt it necessary to satisfy his own hunger or to catch food for her, but he always managed to see that she was well fed tho at this time they dined pretty freely on bees. In fact, that was the only time we had reason to complain of his onslaught upon the bee yard, and with nearly a hundred colonies of bees, 
each one of which was hatching from 3,000 to 5,000 young bees every day, the few it took to keep him and his wife well fed amounted to little, especially as most of them were drones.

Two broods were hatched this first season. The young were given a two weeks' course of education as soon as they were able to fly. They would sit close to the parent birds, first in one tree and then in another, watching for some insect to pass by. For perhaps a week the old birds caught the insects and fed them to the young. One day the latter part of the week, one of the bravest of the young birds made a dart for a butterfly on his own account. When he had succeeded in catching it he carried it back to the tree on which the family rested with as much show of pride as ever a boy felt when he brought home the first dollar he earned. Soon one of his brothers, not to be outdone, made a dart for an insect and within a day or two all of the fledglings were hunting on their own account. Then they moved down into the plum orchard where there were grasshoppers as well as other insects in abundance. Now, the mother began to lay a second clutch of eggs, and Jerry resumed his place as watchman. By the middle of August Jerry and his mate forsook the Red June tree and were to be seen flying across the meadow back and forth, darting up and down, often swooping to a head of clover or a goldenrod and rising again without alighting. There was a haystack on one side of the meadow, and a cornfield on the other. Jerry would often perch himself either on a tassel of corn or on a stake in the haystack, and watch for hours, making a dart after a grasshopper here or a fly there, each time returning to the same spot. In fact, this habit of sitting in a definite 
place watching for food and always returning to the same spot when it is caught is one of the characteristics of the flycatcher family.

Before the first of September the old birds, with both lots of young, gathered in a plum tree one morning, and as soon as they had satisfied their appetites disappeared for the year. The kingbird flies rapidly when he is about his summer's business; but when he starts southward his flight is decidedly different. He flaps his wings three or four times and then sails twenty or thirty feet before flapping again. In this way he rests fully as much as he works and so is able to continue his flight for hours. He flies mostly at night and often stops for a few days at any place that happens to suit his fancy.

Early the next May Jerry returned with his mate. For a day or two after returning they seemed tired, but when they had had a day or two of rest the old fire and vigor returned.

We had a watering trough for horses near the June apple tree, and on hot days it was interesting to watch Jerry take his bath. This was the trough in which the Baltimore orioles bathed. Jerry did not bathe like other birds, but perching on a maple limb that hung over the trough he would dive down into the water, going completely under, always alighting and shaking himself dry before taking another dip. Often he would keep this up for fifteen or twenty minutes if the day was a hot one, making thirty or forty plunges before he was satisfied.

None of the flycatchers have crops. Their food is swallowed directly into the stomach. Since they feed largely on insects and as the shells of these insects are not digestible, the stomach works them up into little balls 
which are disgorged from time to time; so it was common to find little pellets of undigested feet, legs, wings, etc., about the size of a common quinine capsule under our Red June apple tree.

One spring after Jerry had been nesting in that tree for years I put up a martin box on the other side of the yard. I had wanted martins for two or three years, but had never made them a box. Within four or five days a pair of martins took possession, and then trouble began in earnest. Jerry resented the intrusion and was not wise enough to keep his resentment to himself. Doubtless the martins would not have raised any question of ownership; but when war was declared, they entered it with full vigor. The campaign lasted for five or six days, with fighting almost constant. The martin is the one bird that is more active than the kingbird, and poor Jerry came out second best in every encounter. The old spotted cat had always resented Jerry's tyranny, and now she sat in the front yard watching the combat. After an unusually hard fought battle Jerry fell to the ground, possibly injured-I never knew. In a flash the old cat was upon him, and from the way she carried herself it was evident that she felt more than the usual exultation on catching a bird, for she had not only caught her breakfast but had gotten rid of an old time enemy. Before night Jerry's mate left the neighborhood. I had grown very fond of Jerry, and promptly removed the martin house, hoping the mother bird would find another mate and return, but she never came back. 


\section{XXIX}

\section{SAM BLACK}

TN THE grove that had been set aside for a family play1 ground was a crabapple thicket around the edge of which grew a tangle of blackberries and ferns. In front of this crabapple thicket was a bed of giant ferns in which tradition said there was a snakes' den. Just beyond the ferns a little brook danced and sparkled. On the opposite bank of this brook was a wonderful wild grapevine that had so completely covered two young elm trees that it formed a rain proof roof. On one side this vine hung in a loop making a perfect swing. A few feet away, another vine had started to twine about an old tree trunk and then thinking better of it had bent down again and climbed up an elm tree a few feet away, and this bend made one of the finest steeds a boy ever rode. On the other side of this grapevine house stood a young tree that could be bent over to make the best see-saw in the world, and it promptly straightened up again as soon as it had served its purpose, and never once told what had been done.

This grapevine was a regular bearer of delicious grapes, and as it formed a rain-proof house it is no wonder that sister and $I$ chose it as our favorite playground. But we never dared venture into the fernery, for was not this the special domain of the bull snakes that had their den there? True, we never saw any of these snakes; but surely they 
must be there, for Dan Scott had told us so and Dan Scott was authority on all the ghosts, goblins and stinging things in the country.

Old Jim Crow, whose sharp eye saw all that went on in the woods, evidently had observed that tho we children ran at large in this grove at all hours of the day we avoided the crabapple thicket. When the first warm sun began to melt the snow he began to call from every tree top for a mate to come and live with him in our crabapple thicket. Before the first young fox squirrels were nibbling the seeds in the white elms, he had won a dusky bride and they had taken possession of the crabapple thicket.

From our grapevine playhouse sister and I watched them with considerable interest. Back and forth they went, each trip bringing a stick for their nest. The crow carries large sticks, so it was not uncommon for them to bring sticks twelve or fifteen inches long and as thick as my finger. We could see the nest growing from day to day. but we never dared to venture close enough to see the details of the nest building. For three days this work went forward rapidly. The fourth day we observed that they were carying not sticks any more but pieces of string or some other lining material. When the nest was finished it was fifteen or eighteen inches in diameter and was securely wedged in a crotch of crabapple branches where the top was thickest. It was not more than ten feet from the ground but the limbs were so thick beneath, above, and on all sides that had we not known where it was it is doubtful if we could have found it. By this time the warm breezes had started the leaves, the tree had burst into a blaze of pink blossoms, and these blossoms and half formed leaves hid the nest. 
When the nest was completed, Jim chose the top of the tall quaking aspen tree hard by for his watch-tower. There he spent hours scanning the surrounding country and not a twig could snap or an unusual move be made that his quick ear or eye did not catch it. He paid no attention to us children, but let any stranger come near and he immediately uttered a sharp "Caw, caw," and his dusky mate would quietly slip off the nest, and keeping herself well hidden among the branches, noiselessly fly out through the willows near by and would not appear silhouetted against the sky until she was at least one hundred yards from the precious nest. When Jim was sure his mate was well out of harm's way he also took flight but in the opposite direction.

In due time there were young birds in this nest. We knew this for we could see the parents carrying food and soon could hear cries every time the parent birds came near. The mother now spent most of her time flying over the meadows and fields in search of grasshoppers and other food. Jim, being more cunning, divided his time between waiting for a chance to slip into the hen house and steal an egg and watching for a little duck or chicken to wander far enough from the yard for him to catch it without attracting the attention of Jerry the kingbird. Mother complained of the loss of her eggs and poultry, and father threatened from time to time to shoot Jim, but I was insistent that I wanted a pet crow, and this plea, added to the law that nothing should be killed within this grove, caused my indulgent parents to put up with the pilfering until the young birds were old enough to be taken away.

Then it was time to get our pets. Brother John proprosed that we slip down to the nest just at dark, shoot 
the old crows and get the young ones. We laid plans to do this but at the last moment mother persuaded us it would be a mean trick to kill the old birds and take their young, so we had to be content with getting the young and destroying the nest. Perhaps it is hardly just to say we, for I stayed outside of the thicket while Brother John, who had reached the great age of twelve and of course was not afraid of anything, got the birds. There were five of them. We took them all to the house and killed one and hung it on a pole some distance from the chicken yard as an effective preventative of Jim's ravages in that vicinity.

Two of the young birds were given to a neighbor boy, and I started in on the rather doubtful job of feeding and caring for the remaining two. I fed them on bread soaked in milk, pieces of meat, cooked beans, Dutch cheese, mice, and insects of all kinds; in fact, whatever seemed to be convenient.

It is no trouble to teach a young crow to eat. Indeed, eating seems to be his one interest in life. After the first day I could not come in sight without both crows setting up an insistent plea to be fed. To nourish a young crow so that he will gain strength as fast as under his mother's care is quite difficult. Milk was hard to get, and it was easier to stuff the crows with white bread soaked in water than to provide them plenty of insects and milk or curd. While for two or three days these birds thrived amazingly they soon began to droop and have a rough bedraggled looking coat. I stuffed them full of white bread and water every little while, but they were never satisfied. They would utter the most mournful little cry every little while and acted as if they were starving-which in fact they were, starving while being fed to the limit. Finally the 
lining of their mouths became a pale sickly white and one died.

Clearly something must be done. I made excursions to the meadow and fed the remaining bird three or four meals of grasshoppers which relieved the situation very much. The young turkeys by this time had grown large enough to require an abundance of Dutch cheese, which mother began to keep on hand at all times. It was just as handy to feed this to the crow as bread, and it became the staple article of diet. Within two days the crow's mouth came back to a brilliant red, his coat soon took on gloss, and before the week was out he was able to fly. He escaped death by the fortunate circumstance of mother's turkeys requiring an abundance of freshly made Dutch cheese. And just here I will say that if you should wish to raise young birds as pets, there is no food that I have found so generally satisfactory as plenty of Dutch cheese, freshly made from milk that has not been skimmed closely. Of course it is not well to give this as the only food.

When Sam learned to fly he soon became a nuisance-he was so curious. He was always following some of the family about, paying attention to everything that was going on. He appeared as innocent as a baby, but let some one lay down anything small enough for him to carry and then step away for a moment and it was sure to be gone when he returned. Sam made a specialty of carrying off spools of thread, scissors, pocket knives, nails, bolts, screws, etc., and then watching to see what would be done when the loss was discovered. He was sure to be busy jabbering to himself in a low tone when we were busiest searching for the lost article. This went on for some time before we discovered where the things were going. We 
ought to have known, for Sam came on the stage of action after the death of Joe the blue jay, and those of you who have read his history in Elo the Eagle and Other Stories will remember his treasure trove and his proneness to steal everything bright and pretty. But there was this difference between them: Joe either carried his treasures to his cache on the roof or dropped them in the rain-barrel, while Sam dropped his anywhere, even burying them at times. He did not seem to place value on the things he stole, but took them merely for fun.

As he became more expert in flying, he extended his explorations away from home. But some wise spirit taught him that no matter how friendly the home folks might be to a pet crow, strangers were not to be trusted, especially on their own premises. Consequently he never took great liberties there. Nevertheless it was common for him to come flying home with something that belonged to one of the neighbors, but fortunately he never brought anything of value.

Toward fall, when there was an abundance of large, fat grasshoppers in the meadow, Sam spent considerable time hunting there. It is surprizing how many grasshoppers a crow will eat in a day, and grasshoppers were not the only things he caught in the meadow. One day he came home very proud of himself and exhibiting a field mouse that was still kicking. Give it up? Not he! But he did like to show what a hunter he was. After that he managed to catch field mice almost every day. This gave him a new lease of life, when the patience of the family was about worn out with his roguish ways, for anything that catches mice is valuable to a farmer.

When corn husking time came, Sam delighted to follow 


\section{KNOWING BIRDS THROUGH STORIES}

the corn huskers, picking up shelled corn and hunting for the worms that are occasionally found in the end of the ear. Most of these worms had already gone into the ground, but it was surprizing how many Sam would find by tearing the husk open far enough to see the end of the ear.

When fall plowing began he delighted to stalk about over the plowed fields, picking up beetles, worms, and grubs of all kinds.

When winter came Sam did not have to hustle for food as his wild kinsmen do, but nevertheless he enjoyed a rabbit hunt now and then. Flying close to the ground he would locate a rabbit sleeping in a tuft of grass or at the root of a corn stalk. Like a flash he would pounce on poor bunny, probably striking him before he was aware of Sam's presence. Away bunny would dash at full speed. Sam would pursue and flying faster than the rabbit could run every now and then would strike him so that in due time the rabbit became easy prey. Almost always the crow would draw blood the first time he struck the rabbit so by the crimson stains on the snow I could easily track the rabbit as he had run frantically here and there. Sam would finally strike a fatal blow either in the eye or in the back of the head. A wild crow would have eaten his prey entire but Sam usually contented himself with eating the eyes and possibly a few bites of the flesh, leaving the carcass for some brother who might happen by, or for the turkey buzzard that was always sailing somewhere in the heavens on the lookout for just such a thing as this.

In the breeding season crows nest by themselves; but in the fall the longing for companionship and gossip is sure to return, and roosts are established where the crows for 
miles gather every night to roost. These roosts are often pieces of thick timber that cover a hundred or more acres. Trees that do not shed their leaves until spring are preferred for this purpose. I have visited one such roost and it was not unusual to see scores of crows in a single tree while it was an exception to find a tree in which they were not roosting. They continued to arrive till late at night, sometimes flying miles to reach this place. With the first break of dawn they begin to scatter to the fields to feed, usually going back to the neighborhood where they had been reared.

Sam began to grow uneasy as the winter wore on, and would frequently fly a mile or two with a flock of crows that were on the way to a roost in East Central Iowa. But strong as was the desire to know what was going on in the roost and to have a part in the council of the race he reluctantly came back to spend the night in the old willow tree in the yard. After a few days of this uneasiness, we came to feel there was no danger of his leaving, but one night early in February he failed to come home. Next morning he was on hand, however, begging for his breakfast. This went on for a few days, when he began to bring other birds home with him. They did not come to the house to beg for food, but they helped themselves from the corn crib and the chicken house. It was soon evident that this could not be tolerated; we could not feed every stray crow that Sam took it into his head to invite home for breakfast.

There was one crow, doubtless a female, which was clearly a favorite with Sam. Shall I say she was his sweetheart? At any rate they often sat near each other in the orchard and jabbered in crow fashion, she each day grow- 
ing bolder and more free to help herself to the good things the place offered. One evening Brother John cleaned his target rifle and said he was going to shoot the first crow that came near. Next morning Sam came begging for his breakfast, and his lady love began strutting about in the yard picking up crumbs and crusts from the garbage pail. When John stepped out of the house, she flew to the top of a tall tree a hundred yards away. He shot, and as luck would have it, killed her. Her carcass was hung on a pole near the hen house and this effectively put an end to callers. For a few days Sam was disconsolate. Then he did his best to persuade himself and his new friends that it was an accident; but they merely sat in the old orchard forty rods away and watched while he came for his breakfast. Some people say a crow mates for life. I do not know. Sam's first love gone, he did not select another that season, but spent his time gaining wisdom. He flew far and wide. Was he gathering news for the crow's conclave when it met in the old dead tree in Gregory's pasture? He had an unusually keen eye and sharp wit even for a crow. His experience as a pet had taught him so much of human ways that his wisdom was almost uncanny. Tho he usually came home at least once every day or two for food, he soon became the local guardian and leader of this race. When an owl, a hawk, or any other enemy came into the neighborhood it was usually Sam who discovered the intruder and gave the help call, a shrill prolonged "Ca-a-a-ah, ca, ca." Soon crows would come from all directions to help drive away the intruder.

Farmers seldom love crows. Crows like to feed their young sprouted corn and to secure it they pull up the farmer's corn. No wonder every boy in the neighborhood 
was ever on the alert to shoot a crow. Not only could he do so without censure, but he must match wits with a creature so cunning that it is a real triumph to kill one.

Often I have tried to slip up on a flock of Sam's lieutenants when they were heckling an owl or a hawk. Like a true leader, when Sam got his crowd together, he left the work of driving away the intruder to them, while he kept a sharp lookout for their safety. He had totally ignored guns until Brother John shot his friend, but ever afterward he feared even us if we had a gun and were outside of the yard. I could never get within gunshot of Sam and his flock without his knowledge. No matter how busy they were, one sharp "Caw, caw, caw" from Sam and they left their victim and scattered instantly.

Sam was the recognized leader of the flock, and tho young for such a responsibility, it was he who called their council, heard the reports, and then perched silent on the tallest limb and meditated. When calling his counsellors, his call was distinctive. He would perch on the top of a tree and call "Caw, caw, caw," wagging his whole body with every "caw," then wait a few moments and repeat his call. Soon the crows would begin to arrive, but not nearly so rapidly as when they heard the "help" call. Soon all were together and the deliberations would begin. Sometimes they were noisy, more often they were dignified and orderly. No matter, Sam always occupied the highest perch; and remained till his flock scattered.

In the spring Sam selected a mate which refused to nest near home. Soon he ceased coming home at all. Possibly he became too familiar with some of the neighbors' things and was killed. More likely, as I could no longer recog- 
nize him, he became just a crow and lived in the vicinity for years:

Of course we missed Sam, but he was never the jolly companion that Joe the blue jay had been, and I have never cared for another crow. Doubtless they are interesting and it may be that I am somewhat prejudiced against them; but they are not so clean as most birds, and for this reason I do not like to have them around.

Occasionally pet crows learn to talk. I have known two that were as good talkers as a parrot. Such crows are taken from the nest when quite young and reared where they do not become familiar with crow language. Any bird attempts to imitate the sound with which he is most familiar, or perhaps it would be more exact to say the language of those he regards as his own people. No bird whose training does not begin young makes a first class talker. Even parrots must either be taken from the nest when very young, or taken where they will not hear others of their race before they are a year old if they are ever to become really good talkers.

Pet birds seldom mate with wildlings. Whether this is because they feel themselves superior or whether the wildlings consider them outcasts I do not know. That several of my pet birds finally mated and settled down to normal family life pleased me, for it led me to believe I was seeing them under normal conditions, which is, after all, the only way to become really acquainted with anything. 


\section{XXX}

\section{THE BOBOLINK}

NE afternoon in the late spring one of my brothers brought me a black bird with white on the back and shoulder and a whitish bordered buff spot on the back of the neck. In size he was smaller than either the red-winged blackbird or the robin, tho he was certainly more nearly the size of the red-winged black-bird than of the robin. I had never seen a bird like him before and did not know what he was. Strange to say, for once neither father nor mother knew this bird's name. They both said that he was a white-winged blackbird, and that he lived along the roadsides or more commonly along the creeks and that he was scarce in our part of the country. They said he was one of the best song birds we have.

The poor fellow had had his leg broken and his wing hurt in some way or other. Possibly some boy in the neighborhood with a shotgun could have explained how this happened. I got out my largest bird cage, the one I always used in taming my pet birds, and determined to do my best to nurse this bird back to health again. Father whittled out a splint and helped bind up the broken leg and the injured wing, while mother supplied her best mutton tallow and balm of Gilead salve to anoint the wounds. 
This bird never acted as if much afraid, and made no vain struggles to escape. In fact, from the very first he would both eat and drink, tho he resented being handled and would peck and fight with all of his strength if we attempted to lay hands on him. Seemingly aware that he was being helped while we were dressing his wounds, however, he was usually quiet. He had a stout bill and could pinch hard with it. I have had him pinch hard enough to draw blood more than once.

We fed him a variety of food. Our never failing Dutch cheese was the staple article, but to it we added such worms and bugs as we could catch, wheat, the seeds of various kinds, bread, and even fresh apple. He improved rapidly and within a week was beginning to chirp, and truly he had a very musical voice. In a little more than two weeks he was able to fly about in the room, tho he did not use his broken leg perfectly as yet. He was still a bit shy, and in making an attempt to get out through a window which he evidently mistook for an opening he injured his wing slightly again. Immediately I put him back in the cage where he stayed another week. By this time he felt at home with the family. His leg apparently was completely well; at any rate in jumping about and swinging in the cage he used it as well as the one that had never been hurt.

Not wishing to repeat the experience of having him injure himself against the window pane, I hung the cage out in a tree and opened the door. Presently he noticed this open door and hopped over and sat in it for a time looking longingly at the trees, but apparently uncertain as to whether it was wise to venture to fly. Finally he made up his mind to make the attempt, and soon was hopping 
about among the branches as happy as could be. But for two or three days he did not go far from the house. Then he began singing his wonderful rollicking song, whistling and calling for hours every morning, evidently in hopes that he might find a mate. It was not until he was turned loose and began singing that we recognized him as a bobolink. Even now I am not sure whether we guessed it ourselves or whether some one told us his identity.

This was my first experience with a bobolink. I never knew whether this bird found a mate. At any rate he left us within four or five days after he became able to fly and never returned. We frequently heard a bobolink singing in the meadow, the grove, and the orchard near by; but as I never found its nest, I was never sure that it was my liberated friend.

The male bobolinks come north a week or two before the females, and for two weeks are as care-free a lot of bachelors as one would care to see. This time is spent in making the fields and meadows ring with song. When the females arrive they are to be courted and won before nest building can begin, and as my bird was found about the time the first birds arrived he was probably healed before the last of the females arrived.

The bobolink should be given a place among our half dozen best songsters. $\mathrm{He}$ has a wonderful range of notes and it would be hard to improve on his song. Beautifully colored as he is, his mate is a dull, soberlooking brown bird. Nevertheless he is always proud of her and does his utmost to entertain her with song during the brooding season. He feeds on a variety of things, eating caterpillars and insects of various kinds greedily in the summer time. He seems to be especially fond of 
army worms, those caterpillars that form in numberless bands and march through our fields destroying everything. When the babes arrive, however, he prefers to feed them on young grasshoppers. Those who have watched him feed his young, patiently noting hour after hour and day after day what he feeds, claim he has a great preference for green grasshoppers-not any particular kind of green grasshoppers, but just green ones-not feeding brown ones once out of a dozen times.

After the mating season is over "Robert of Lincoln," as he is sometimes called, loses his fine feathers and becomes a dull brown not much different from his mate. Now with his family he flies away to the Southland, on his way to South America to winter. On the way he is not found in the edge of meadows or by the roadsides swinging on a thistle and singing his jolly, rollicking song. Instead he gathers in the Carolina rice fields in enormous numbers, feeding on rice until he is almost too fat to fly. Apparently he is so fond of rice that he forgets all his good manners and his caution as well and does not even leave the field to roost. Doubtless this over-fondness for rice is responsible in two ways for the fact that large numbers are destroyed in some parts of the country. First, it makes him so fat that his carcass is considered a very toothsome delicacy; and second, roosting as he does in enormous numbers in the rice fields, he becomes an easy prey to the men who are hired to hunt for him.

A man will take a torch or a brilliant flashlight, a tow sack, and a short broad paddle, and start for the rice field. Holding the sack mouth wide open under one arm and carrying the torch in his hand he moves slowly through the rice field. The light blinds poor bobolink and at the same 
time reveals his presence to the hunter. Robert sits bewildered by the brilliant light, until the hunter gets close enough to strike him with his paddle and knock him off into the sack. Scores are often collected in this way in a single evening.

Undoubtedly bobolinks become numerous enough in the rice fields to be actually injurious, and doubtless the man who feeds these birds has some claim on them; but nevertheless it seems too bad that so brilliant and jolly a song bird should be sacrificed by tens of thousands every year for no higher purpose than to be eaten. Surely if God ever made anything to cheer us and make us happy it was the bobolink, and it always seems to show a lack of appreciation of the really worth-while things in nature when people deliberately kill song birds for food. It must be admitted, however, that Robert never sings in the land where he feeds on rice and is slaughtered. This makes the case of his enemies appear more plausible, for many of them do not even know his virtues in the parts where he raises his young. It seems remarkable that a bird should be largely an insect eater in his northern home and a grain eater on his migrations. Perhaps he himself is ashamed of it, for he changes his coat so effectively that even his best friends in the North might not recognize him in the rice fields of the South.

In the Northeastern part of the United States, where the bobolink is most common, he sometimes forgets his good manners and becomes a nuisance as soon as the corn is in roasting ear. He occasionally gathers in the fields by hundreds, and creates great havoc by tearing open the ends of the ears and eating the sweet young corn. 


\section{XXXI}

\section{THE GRAFTER}

LMOST any time in the spring and summer I could
look out over the cow pasture and see a dozen or more dull-brownish black birds (the males were a shiny black) either picking around on the ground near the cows or sitting on their backs. They would actually sit on the back of a cow for a half hour at a time, and the cow seldom paid any attention to them, or if she did she seemed rather to encourage this friendliness. These birds were not shy, and when I would go to drive the cows into the lot to be milked it was not unusual for me to get within fifteen or twenty feet of them. They came for a while to be great favorites, even though they never sang and were not pretty. Their color was not attractive and I have always believed a bird should sing; but nevertheless I liked the way these birds caught the flies off the cows' backs.

There is a certain insect that lays its eggs so that the cow gets them in her mouth and swallows them. When these hatch and the little grub finds its way into the cow's circulation, and finally lodges in the tissue, just under the skin along both sides of the back; there the grub grows and feeds until spring. By that time they are almost as large as the grub worms we often find in old straw stacks or in the ground in our gardens. They eat holes through 
the skin, erawl out of the cow's back, and drop on the ground where they are transformed into the mature insect.

Father taught me that cowbirds eat these grubs when they crawl out of the cows' backs and so are a protection to the cows. I am inclined to doubt this, for while those birds lived with our cows for years, every spring the cows' backs were full of the "warbles." If the birds had been active in catching the grubs, they should have grown less numerous from year to year.

Finally I discovered something about these birds that changed me from their friend to their untiring enemy, and finally I exterminated them from our farm.

Our peach orchard was a favorite nesting place for yellow warblers, vireos, and other small birds. One spring a red-eyed vireo nested in my favorite peach tree. This was a seedling that ripened its fruit very early and was of exceptionally good quality. That spring I had fallen into the habit of visiting the tree every two or three days speculating how long it would be before I could get a ripe peach. One day I discovered a vireo's nest there, containing three eggs.

The next day there were still three eggs in it, but they were not all vireo eggs. One was much larger, and there was a broken vireo egg on the ground underneath the nest. I could not understand that, so I went back to the nest the next day and found another vireo egg in it. Then the vireo began sitting. Of course $I$ was anxious to see whether the big egg would hatch. It never occurred to me that it was not a vireo's egg. Sometimes one of our hens would lay an unusually large egg that contained two yolks. Again one sometimes laid an egg not much larger than a pigeon's egg, so it did not occur to me that this egg 
belonged to some other kind of bird. But I was puzzled about the difference in color. However, as there was occasionally a variation in the color of the eggs of a chicken, I thought little of that. I had set a number of these large hen's eggs in hopes of getting a double chicken, but none of them had ever hatched. Now I was anxious to know whether this egg would hatch a double bird.

Well, it did hatch and not into a double bird. Three days before the other eggs hatched I found this one had hatched a lusty little bird indeed. The vireos began feeding it, but it was never satisfied. By the time the other eggs were due to hatch, it had broken one of them, which of course meant that the bird it contained was killed. I carefully removed this dead bird with two sticks, but was still ignorant of the character of the lusty bird that had hatched before its fellows.

When the other eggs hatched it was evident even to me that they would not be the same kind of birds as this stranger. I was more anxious than ever, however, to find out what this bird would prove to be and so waited and watched. The two young vireos had no chance for their lives. They were so weak that their lusty mate managed to get all the food the parents brought and trampled its nestmates until within two days one of them was dead. The other evidently received little food for it grew slowly but never seemed anything but starved. I felt sorry for it and began feeding it with egg yolk, dutch cheese, and small grasshoppers, often feeding it all it would eat two or three times a day. It then began to thrive and I verily believe I saved its life.

The young stranger was beginning to get feathers and to my surprize they were black. It never seemed satisfied no 
matter how much it was fed, so I sometimes gave it portions when I fed my little vireo. In a few more days it was able to sit on the side of the nest and beg for food, meeting the vireos before they could get to their own young at all. Now the young vireo depended entirely on my bounty; but the mother bird had become so accustomed to me that she did not resent my lending a hand. Two days later this bird was fully fledged and ready to fly. Then it was evident what it was-one of these brownblack cowbirds. Almost as soon as it left the nest it was able to care for itself and it soon joined the birds in the pasture. The old birds welcomed it, but I have often wondered what it must have thought of its mother when it saw her. Surely there is little respect or affection among such birds. After that the vireos turned their attention to their own young, and it was surprizing how it changed in appearance and grew.

A survey of the birds' nests in the orchard and vineyard revealed the fact that these were not the only birds that had raised a cowbird. A pair of yellow warblers raised one. When I found their nest it was the only bird in it. I never knew what became of their own young, whether the cowbird threw them out of the nest, whether they were starved to death, or whether possibly they never hatched. At any rate this bird was the only youngster that grew to maturity. A pair of song sparrows raised a third. Doubtless one or two other cowbirds were raised by other small birds in the vicinity, but I never found them. Further watching led me to know what hundreds of people had known for a long time, that cowbirds never nest. They sneak to the nests of the smaller birds and slyly deposit an egg in each nest until they have laid several 
eggs. They throw out of the nest on occasions one of the eggs that rightly belong there. Sometimes they break and throw out more than one.

The cowbird is very sly and remains on a nest only a few moments. She often lays in nests that are so small it does not seem possible that she could sit on them. The cowbird usually hatches two or three days before the other birds, and either tramples or starves the rightful children to death. The cowbirds do very little good, and for erery one of them that is hatched at least three valuable birds are destroyed. That was the reason why I declared war on them and exterminated them from our pasture.

If a cowbird lays an egg in a yellow warbler's nest, as it frequently does, these wise birds often refuse to act as foster parents. They construct a second bottom in the nest, burying the stranger's egg, sometimes even burying their own, and then lay more eggs on this new bottom and proceed to rear their own family.

The cowbird belongs to the same family as most of our other blackbirds. None of the blackbirds are exceptionally desirable birds, most of them having some decidedly bad habit. Among the most desirable are the redwinged or swamp blackbirds, which we see in large flocks in our groves and fields in the spring and fall. The redwinged blackbirds are tolerably respectable citizens, and if it were not for the fact that they destroy considerable grain, few would object to them. You will have no trouble in recognizing blackbirds, for of course they are black or nearly black, and all of them are moderately small birds. Few other birds are black all over in color except the crows and ravens, and they are much too large to be mistaken for blackbirds. 


\section{XXXII}

\section{THE MEADOW LARK}

NE day when I was about ten years old I was playing in the meadow when I discovered one of the nicest little tunnels I have ever seen. It was an oval archway perhaps five inches in diameter, leading under a large tuft of grass. I explored it and found it ran back at least two or three feet. Of course I was all interest at once because aside from the tunnels of the bobtailed meadow mice and the ants I had never seen anything of the kind, and I knew this tunnel was far too large for such small creatures as these.

The tunnel made a turn, and I was not able to see where it led without disturbing it. Knowing that there must be some interesting story at the other end, possibly something that would need watching for days, I did not want to injure it, for I knew that if I did the little creature that made it might forsake it. By very carefully pushing the grass apart on the other side I was finally able to see that after running for eighteen or twenty inches in a straight line the tunnel turned abruptly to the right and after running fully as much further there was a nest and in that nest were five spotted eggs. Surely this nest belonged to a wise bird, for nothing flying overhead could see the little mother when she was sitting, and the babies were 
likely to be safe until they were well able to take care of themselves.

The mother did not happen to be at home, so I stationed myself some fifty or seventy-five yards away, began plaiting chains of white clover blossoms, and awaited her return. After half an hour or so I noticed a meadow lark flying by, but it did not occur to me that this nest belonged to her. True, I had never seen a meadow lark's nest, but I had known larks all my life, and she acted so naturally that it was not suggested to me that this bird was trying to learn whether I had found the nest and whether it was safe to return. She alighted in the grass near by and seemed to busy herself looking for worms. In five or ten minutes she flew by again and alighted on the other side. Again in a few minutes she came by, each time getting nearer the nest.

Presently she gained a little more courage, alighted within ten or fifteen feet of the nest, and began pecking about here and there in the most unconcerned way possible. When she felt sure no one would notice it, she ducked her head as low as she could and made directly for the tunnel and slipped in to the nest. Then the secret was out. It was a meadow lark's nest; the first I had seen and for that matter the most cleverly hidden of any nest I had known, excepting perhaps that of the humming bird. Meadow larks always build their nest in the grass, but they do not always take the trouble to conceal it as this one had done. In fact, it is seldom that I have found a meadow lark's nest hidden away in a tunnel where curious eyes could not find it.

Lady Lark was a careful, painstaking housekeeper, never allowing the least bit of trash or dirt anywhere about 
her nest. If any debris was left about my lark's nest, the old bird managed to carry it away. She even carried away pieces of paper I left to mark the nest, probably fearing that they would attract attention to the place.

Many birds that build their nests on the ground lead the young away from the nest almost as soon as they hatch, but this is not true of the lark. Its young remain in the nest until fully grown. The mother bird feeds them on insects.

The meadow lark lives over a considerable portion of the United States and is usually to be found on the ground in meadows and pastures. These birds are plump and active, about the size of the common bob-white quail, but rather more slender. They have bright yellow throats and a black V-shaped blotch on the breast, which serves to identify them. If we see a brown bird about the size of a quail, with rather slender neck and a yellow throat, running about in the meadow and pastures, we can be pretty sure that it is a lark. There are two varieties of meadow larks, and they are best distinguished from each other by the variation in the yellow around the throat and the color of the upper parts, wings, and tail. Each kind has a song of its own, altho even the song has some similarity in the two varieties.

Meadow larks are among the first birds to be heard in the early spring, and I have always considered them among our most delightful songsters. We do not hear them sing so often in the late summer or early fall; but on any bright day in the winter and from then on through the spring and summer they may be heard every morning. As the fall approaches, most of the meadow larks move to the South, but many remain all winter. I have seen them by 
the hundreds on the bare prairies of the Missouri River valley between Omaha and Sioux City when the thermometer was twenty below zero. At such times their food consists largely of such seeds as they can pick up. The day is never so cold but that if the sun comes out and shines for an hour or two you can hear them singing their thankfulness for its warmth. Where I now live near Nashville, Tennessee, larks come in by thousands every fall and are to be seen in great numbers almost every day. In fact, I can sit in my class room and look out over the pasture and see a dozen or more disputing the hunting grounds with the kildeers. Most of the larks go farther south than our locality, and in the latter part of January or the first of February as they begin to work their way back northward the fields and meadows are all atune with them. They move north leisurely, having a good time as they go, so it is no uncommon thing for them to spend several weeks with us before going further.

Our meadow larks are not much like the English lark. In fact, ours are not really larks. The English birds have a prolonged song, while ours merely whistle a delightfully musical note, and repeat it every few moments. As I write this, December tenth, I can hear the meadow larks singing in the distance. They have come from the north and, unlike the bluebirds, are singing their thankfulness for a delightful winter home.

I have introduced you to the meadow larks, but I have not said one word about their company name. When a lark is introduced into learned company he is not presented as "Mr. Lark," but as "Mr. American Oriole," (a later name than starling), for that is his name in the big books. 
This may sound ever so well to those who are used to it, but when as a boy I read about the American orioles I had not the least idea that they were my everyday friends, the larks. Call them larks if you choose, but you should know that they are really American orioles just the samenot a relative of the black, pilfering starling of Europe. Our meadow lark feeds entirely in the meadows, and eats mostly insects, seeds, and a little grass. 


\section{XXXIII}

\section{THE HANGING BIRD}

NE morning early in May mother and I were out in the apple orchard admiring the blossoms and looking for the old mammoth bronze turkey's nest. Hoping we might be able to track her to her nest, we were partly hidden behind a grape vine watching the old turkey as she stole through the clover. Suddenly a bright orange streak flashed before our eyes and a black and orange-yellow bird about half way in size between a bluebird and a robin alighted on a limb almost above our heads and began caroling its song. I watched it almost breathless for fear it might see us and fly. To me it was a new bird. I had doubtless seen it before, but small boys do not always notice all they see nor remember all they notice. This bird was such a brilliant orange-yellow, with such black wings, tail, and head, and its voice was so musical, that the thought came to me at once, "I wish this bird would build its nest somewhere near, so I can watch it this summer."

Presently the bird flew away and I said to mother, "What kind of bird was that?" She replied that it was a "hanging bird," and to my question, "What is a hanging bird ?" she explained that it was a bird that builds a hanging nest. I asked if she supposed it possible that it would nest where I could see it, for I had never seen a hanging 
bird's nest. "Yes," she said, "if you will get bunches of horsehairs and pieces of string and put them about on fence posts and in the limbs of trees, most likely this bird will find them and decide to build its nest where material is plenty." At once I asked where to get the horsehairs and was given permission to take a pair of scissors and go to the barn and cut a small bunch here and there out of old Phoebe's and Flora's tails. Phoebe and Flora were the old sorrel horses that were the main stand-bys on the farm. Mother made me promise that I would not get hair from the other horses' tails and that I would not get so much as to spoil the looks of their tails; and away I went, happy as could be, to get my horsehairs. As luck would have it, father was in the barn; and when I told him what I wanted he not only let me clip from Phoebe's and Flora's tails but got me a fine bunch of long white hair from Tuck's tail, and some long black hair from Napoleon's.

Armed with this supply, I put horsehairs in the cracks and under the splinters of every post and fence stake within three or four rods of the great red maple tree that grew near the milk house pump. Later mother gave me some short pieces of cotton warp that were left when she had finished threading the loom for a new carpet, and these were scattered about in the same way.

Nothing happened for a day or two, and by that time I was busy making stick nests in the box elder trees below the barn in the hope that a robin would decide on one of them as a convenient home for him, and my horsehairs and strings were forgotten. I suppose I must have built a dozen such nests, or what I called nests, and came home at dinner time full of plans to tell mother about the won- 
derful things $I$ had been doing and the still more wonderful ones I meant to do. But before I got the story half out of my mouth she said, "Floyd, do you know the hanging birds are using your horsehairs today?" Of course, I could not eat dinner until I had gone out to watch, and sure enough these birds were busy carrying strings and horsehairs into the very top of the red maple tree, where they were weaving them into a baglike nest. A place had been selected where the strings could be woven about three limbs, so the nest would be perfectly secure. For nearly a week the birds worked busily carrying strings and hairs, and after the second day more or less grass, to this nest. When it was completed it was a sort of bag about six inches deep and three or four inches in diameter. It had been woven together so securely that it was almost as strong as a cloth bag would have been. Inside of this baglike network was a lining of wool from the sheep shed, feathers from the chicken yard, and soft grass and moss. The nest was so high that I could not climb to any place where I could look into it, and both mother and father told me that this bird is so shy that if I ever touched the nest they would leave it even tho there were young birds in it. I used to climb the maple tree to within ten or twelve feet of the nest and watch it with longing eyes, but never dared go nearer-not because I was afraid the birds would leave the nest but because the limbs were so small that I feared they would break with me. I spent so much time watching this bird that she finally came to regard me as a necessary evil, and went about her business as tho I were not near.

You will probably wonder what the real name of this bird is, for doubtless you know that "hanging bird" was not 


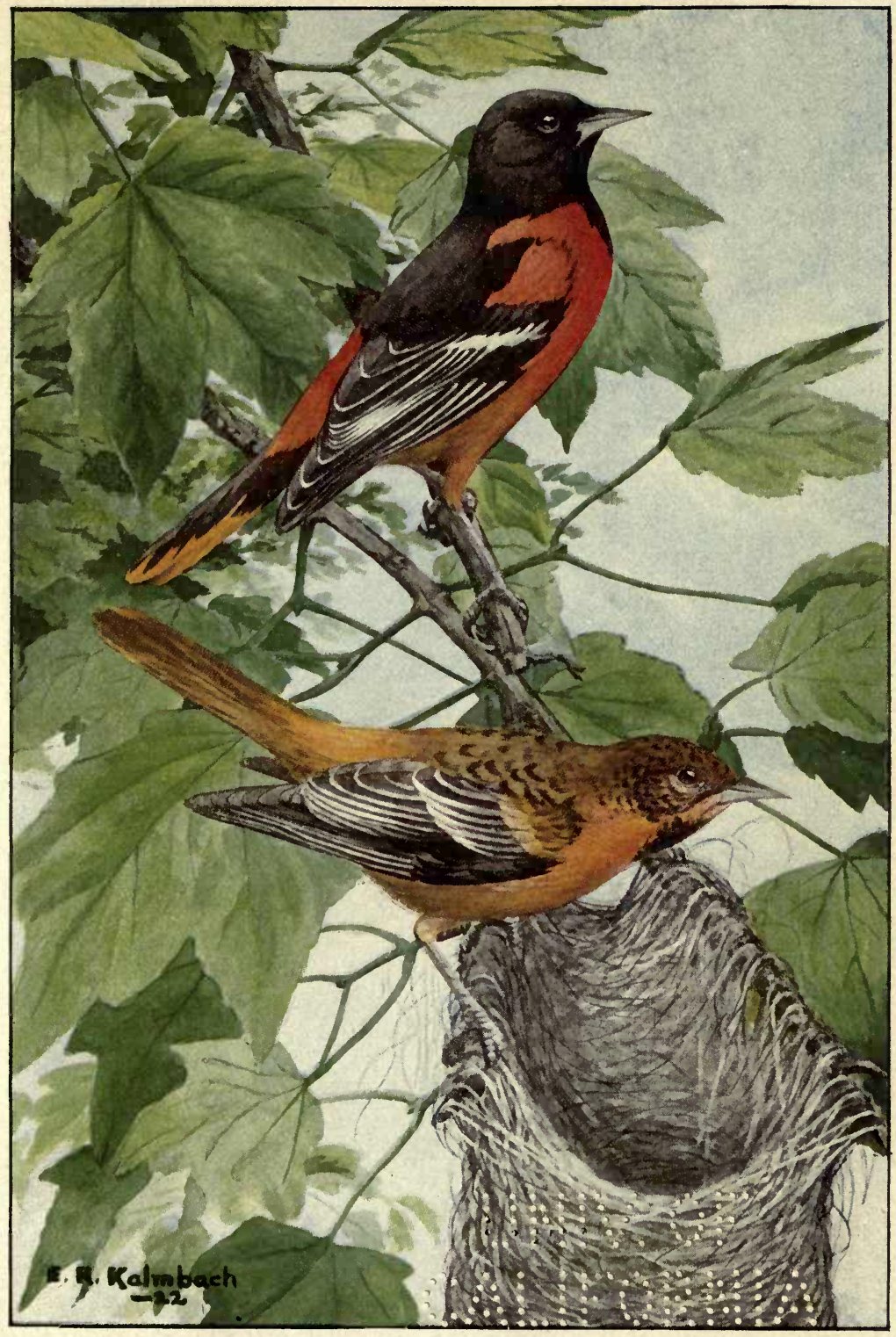

THE BALTIMORE ORIOLE

Upper Bird-Male Lower Bird-Female 

its real name. It was a Baltimore oriole, a bird that most of my readers can find in their orchards if they but take the trouble to look. There are several varieties of orioles, most of them orange or yellow and black in color and all about the same size. So far as I know all of them build hanging nests. Some of the others are fully as brilliantly colored as the Baltimore oriole.

We were especially delighted to have this nest by the side of our orchard, because these birds feed on small moths and butterflies or their caterpillars. The codling moth, which lays the egg that makes the apple worm, is especially liked by the orioles, and many farmers believe that a pair or two of orioles nesting in the orchard will save at least fifty bushels of apples from becoming wormy. In those days we knew nothing about spraying to keep away worms, so orioles were always welcome with us. In Knowing Insects Through Stories,* you will find some of the methods we used to get rid of the codling moth, but we relied on the birds about as much as on anything to prevent wormy apples.

Those birds used to drink and bathe regularly in the trough where we watered the horses, just outside the yard under their maple tree. I liked to hide among the blue damson plum trees and watch them take their daily bath. First Mr. Oriole would alight on the side of the trough, drink a few swallows, throw a few drops of water over his back with his bill, edge about on the side of the trough looking for a place that suited him better, stick his head in the water and rub it over his shoulders, splatter a time or two with his wings, and then, perhaps, hop on the fence

* Published by Funk \& Wagnalls Company, 1921. 
or on the lower limbs of the tree, look about, shake himself again, and I would be disappointed, feeling sure he was not going to bathe after all. Presently he would hop back on the side of the trough and again begin dabbling in the water. After a few moments of these preliminaries he would hop off into the trough even tho the water were five or six inches deep, and fairly make it fly as he splattered with his wings, ducked and dived until in a few moments he was wet to the skin. After that he would scramble up on the side of the trough, shake himself a time or two, and then begin drying the water out of his feathers. If danger had come just at that time, he would have found it difficult indeed to escape, for I have seen him try to fly to the top of the fence not more than three feet above the trough and hardly succeed in doing so. After fluttering and shaking himself as free from water as possible he usually hopped to the top of the tall corner post, which always caught the sun, to finish drying himself. Here every feather was carefully smoothed out and drawn through his bill till it was clean and smooth, and then he flew back to look after household affairs and allow his wife to take her bath. It was never long before she appeared and bathed as enthusiastically as her husband, but I never knew them to bathe at the same time. One always waited until the other was through and thoroughly dry.

I usually had several bird pets, and naturally became anxious to add an oriole to the number, but it was a question how I was to secure it. I could not climb to the nest, still I had hopes that I could catch a young bird as soon as it left the nest, but before it was able to fly well. I watched carefully, but when the young birds left the nest they were able to fly so well I could not catch them, so 
there was nothing to do but wait for the second brood. In the meantime a neighbor, Milo Lemley, succeeded in getting some young birds just as they were ready to leave the nest. Not knowing what to feed them, he put them in a cage and hung the cage in a tree near enough the nest for the parents to find it, yet close enough to the porch for him to watch what the old birds did. In this way he hoped not only to avoid the trouble of feeding his birds but also to learn what they were fed. We often did this with young birds, and in this way found out much we might never have learned otherwise.

The old birds found their young promptly and fed them readily the first day; but they also tried in every way they knew to get their young out of the cage. The cage was taken indoors at night, and put out again early the next morning. Again the parents fed their young, but both old and young made even greater efforts to open the prison doors. Finally sometime after noon the parents seemingly decided it was of no use; so they stopped trying to get into the cage, and again went for food for the young. After feeding them this time they flew away and did not again return to the cage. Before night every young bird was dead. It did not seem possible that they had starved, so we felt sure the old birds had poisoned them rather than allow them to languish in prison. Both mother and Milo's father said that these birds will poison their young if they are caged. After that I never tried to catch young orioles, for tho I always gave my pet birds as great freedom as the wild birds as soon as they had become tame, yet I felt it would be cruel to keep, even for a short time, birds that preferred death to captivity. Others have caged young Baltimore orioles, however, and report that the 


\section{KNOWING BIRDS THROUGH STORIES}

parents feed them readily, and that they are easy to rear.

My orioles nested in the top of the red maple tree year after year, even after I no longer put out nesting material for them. Perhaps they never missed my cooperation, for in a farmyard there is usually plenty of wool and hairs on pasts and trees against which animals have rubbed. 


\section{XXXIV}

\section{PETER THE GOLDFINCH}

P ETER was a goldfinch. He never told me where he 1 hailed from nor just how it happened that he was alone in the world; but I had always suspected that the old spotted cat knew something about it, for a day or two before I met Peter she had a lady goldfinch for her breakfast.

I was in the garden planting peas when I heard a rustle behind me and looked around. There was Peter, hopping about in the raspberry patch hard by, dividing his time between singing and trying to get the seeds of an Indian lettuce head. I noticed him particularly because he was one of the most brilliant colored finches I have ever seen, and he had a white feather in his tail which served to distinguish him from the other goldfinches in the vicinity. Our gooseberry and raspberry patch, at the side of the garden, and the plum orchard beyond had long been favorite nesting places of the goldfinches- "wild canaries," we called them; so I was not surprized to see Peter. As he could be easily recognized by the white feather in his tail. I determined to get acquainted with him.

I then had no idea that these birds were not really canaries. They are about the same size and the males are as brilliantly colored as a canary. I had often wondered 


\section{KNOWING BIRDS THROUGH STORIES}

why the wild ones did not sing so well as those in our neighbor's cage. I realized that they are slightly heavier in build than canaries, and that they have black wings and a black cap; but canaries often show a great deal of black, and resemble goldfinches fully as much as the wild pigeons resembled the tame ones that nested in our barn. I find that most people make the same mistake of calling the goldfinch a wild canary. At home when these birds played havoc with the seed on an especially desired lettuce plant mother spoke of them as lettuce birds but that was only a temporary name. In my own mind I ascribed their inability to sing as well as tame canaries to their lack of training. The facts are that they belong to the same family but are different species.

Peter had no wife. This was not Peter's fault, for of all the goldfinches in the vicinity none was more gallant to the lady goldfinches and none sang so often as Peter. In fact, it was this insistent singing that caused me to watch him carefully enough to learn that he was a bachelor.

Goldfinches are sociable birds and usually fly in flocks of at least half a dozen. Alighting on a sunflower head or a weed that promises to furnish seed, they hunt carefully for some time and then fly away together to the next place. They have a peculiar up and down motion in their flight, and a "Cut-a-cut-cut" in a sweet wave like voice as they fly. Should they pass where others of their kind are sitting, they always receive an invitation to stop for a visit and seem always to accept the invitation. Peter was different. He hunfed alone in the garden and the meadow, tho he always invited every passing flock to dine with 
him. Often he flew away with them, but it was not long till he was again in his own garden.

The fall before I became acquainted with Peter my Aunt Eve Adams had given me a canary bird. It was scarcely grown, and no one knew whether it would prove a singer or not. I cared for this bird carefully and it had become very tame. Each day I watched for it to begin to sing. My friends, wise in bird lore, said it did not sing because I allowed it too much freedom. I never believed birds were made to live in cages. I had a cage for my canary, but it was little more than a convenient roosting and feeding place, for the bird was allowed the freedom of the house.

I called this bird "Dick." Had I waited a year, the name would have been different. Dick soon learned that the stove pipe was apt to be hot and that the dining room table was forbidden ground. Otherwise he went wherever he pleased. He was on the best of terms with the old spotted cat. It was not uncommon after we had all been away for some time to find this cat quietly dozing behind the stove with Dickie sitting on her head pecking at her ears. If he happened to peck a little too hard she would open an eye sleepily, utter a little mew of protest, and perhaps shake him off of her head and then go back to sleep.

When the weather became warm I often hung the bird cage in the great willow tree in front of the kitchen door, and before many days Peter discovered and began paying attention to Dickie. Finally it dawned on us that Dickie had been misnamed. We left the cage door open most of the time. At first Dickie seemed afraid of the great outof-doors but before long she flew everywhere, but always 


\section{KNOWING BIRDS THROUGH STORIES}

came back before dark. This came to be a habit, and after that we did not take her cage in overnight.

I never knew just when it happened, but one evening I discovered that Dickie was not in the cage. Probably she had been gone for several nights. Mother said she came back several times every day for seeds that were always kept in the cage and for water. Nevertheless she had been spending considerable time in the garden with Peter.

It was the strangest occurrence I have ever known among the wildlings; but Dickie and Peter fell in love with each other, and finally Dickie ceased to come back to her cage at all. We left the cage in the tree for two or three weeks. But when Dickie did not return it was finally taken into the house to await the needs of the first crippled bird found in the neighborhood. We supposed that Dickie, having been reared in a cage, had lost the instinct of the wildlings and had been unable to cope with the hardships of the great out-of-doors.

One day late in August I went to see if the Miner plums were beginning to ripen. Imagine my surprize to have Dickie meet me and alight on my shoulder as friendly as could be. She seemed overjoyed to see me again. Soon I noticed Peter. He was sitting in a plum tree near by and seemed very much concerned over the turn events were taking. He scolded and protested until it dawned on me that Peter had at last found a wife and that his wife was Dickie. Then I understood why she had forsaken her cage. Before long I found their nest. It was not at all like the nests we see in a canary's cage. I have never seen a wild canary's nest, but from its description in the books it must be something like the nest of the goldfinch. 
At any rate Dickie's was built very much like the nest of the goldfinches near by, tho it did not show as fine workmanship.

Goldfinches are peculiar birds. They are in the North always early in the spring, but for some unexplained reason do not nest until August. Just at the time other birds have finished their year's brooding, and are beginning to molt and get ready for winter, the goldfinches think about rearing a family. Possibly they have been waiting for an abundance of milkweed and thistledown. At any rate they raise their young in a veritable bed of down gathered from these weeds. The outside of the nest is closely woven of fine grass and shreds of tough bark, but the bottom inside is a cushion of down sometimes an inch thick. For so tiny a nest it would seem unnecessary to make so thick a base, but evidently this bird, having waited so long, means to give its young the best that can be had. The nest is often placed in a bush or low shrub, not more than five or six feet from the ground. However, for years our plum thicket was a favorite nesting place for these birds, and as the trees had been pruned so that the lowest limbs were five or six feet high, their nests were usually ten or twelve feet from the ground; and nests have been reported as high as thirty or forty feet.

The goldfinch sometimes weaves lichens in the outer corering of the nest, like the wood peewee, so that it is difficult to discover. The goldfinch lays from four to six bluish white eggs, not differing much from canary eggs except that these last are usually marked with reddish brown.

The female goldfinch usually does all of the nestbuilding, tho her mate sometimes assists in carrying material and always feeds her while she is brooding. The mother canary 


\section{KNOWING BIRDS THROUGH STORIES}

is also usually insistent on building her own nest, so the resemblance Dickie's nest bore to those of the goldfinches about her may have been due to the material furnished by her spouse. When winter came, Peter, Dickie, and their family flew away to the Southland.

The goldfinch feeds largely on weed and grass seeds, and, small as he is, where these are abundant, he often remains all winter, even where the thermometer goes well below zero. 


\section{XXXV}

\section{THE SONG SPARROW}

N my way to school and as I played in the fields I was always charmed with the song of the song sparrow. This is a small brown bird possibly a little less heavily built than the English sparrow. The resemblance in shape, size, and color is close enough so that probably most of my readers would be able to recognize him as a sparrow from having known his quarrelsome foreign cousin.

But with this physical likeness the resemblance ceases. The English sparrow is a spiteful, quarrelsome bird with anything but a musical voice. He resembles nothing so much as the quarrelsome, fighting street Arabs with whom he lives. He seldom does anything which is of value to man but is a genuine nuisance because he is so often quarreling, fighting, or pestering some poor birds that are both musical and beneficial, until it leaves his vicinity in disgust. On the other hand, the song sparrow is one of our gayest and sweetest song birds. One could not travel the roads near my boyhood home for a quarter of a mile without seeing several of these birds sitting on fence stakes, the top wire of a fence, or on weeds or twigs, every one singing as if his whole mission in life was to cheer passers by. 
Some birds have a musical voice but a limited range to their notes. Other birds have a wide range of notes but little music. The wood thrush is an example of the first class while the blue jay is a good example of the second. Perhaps few birds have a wider range of notes than he; yet few birds have less music in their voice. The song sparrow is different from both these. He not only has a delightfully musical voice but there is enough variation to his song to make it pleasing indeed.

He builds his nest in the meadows or orchards; usually the nest is on the ground and sometimes in a bush or a tree. It seems that these birds can never be sure which is best. They raise three broods each year, and build three nests in which to do so. The first may be on the ground, the second in a tree, and the third in a bush, or vice versa. The nest is made of grass and lined with hair, usually horse hair. The eggs are bluish white, speckled all over with brown. My observation has been that six are usually laid in the first clutch, five in the second, and only three in the third. The young are fed largely on insects. The mother is a faultless housekeeper, carrying all litter thirty or forty feet from the nest. In fact, when her young are ready to fly, her nest is in as good condition as that of most birds when first built. A new nest would seem wholly unnecessary, but this bird will take no chance with vermin or disease-strange contrast with her filth loving English cousin. The old bird feeds almost entirely on insects and weed seeds; and, living as he does where weed seeds are most apt to be a nuisance, his efforts in this line are beneficial indeed.

After you have learned to recognize sparrows by their shape and general appearance you will be able to distinguish 
the song sparrow from the others by his beautiful song. The song sparrow is one of the first birds to arrive in the spring and one of the last to leave in the fall. In fact, as far north as my old home in Southeastern Iowa they sometimes stayed all winter. At intervals, when there were warm days, they sang even in the winter. In fact, I think I especially loved these birds because they were so cheery and full of song when there were so few birds about.

I am not attempting in this story to tell the story of one sparrow only, but to help you to learn about sparrows in general, for they are numerous in this country. It is said that on the average about every tenth bird in the United States is a sparrow, and this is not necessarily because of the large number of English sparrows either. Most of our American sparrows, of which we have more than a hundred kinds, are beneficial because they live so largely on weed seeds and insects.

Another of our most common and widely distributed sparrows is the chipping sparrow, so called because of the peculiar "chip, chip," which is the most common note it utters. As a child I knew it as the "chip bird." You will find it easy to locate one by its chipping song. 


\section{XXXVI}

\section{THE TOWHEE}

THE desire to know the wildling springs as naturally in

1 a boy's heart as to breathe the fresh air or run in the warm sunshine. I am sure that when as a five or six-yearold boy I used to beg a pin from mother, bend it into a fish hook, tie a twine string just below the head, and trudge away to Wymore's Branch to spend an afternoon fishing, it was not just because I liked to catch fish. I think the greatest pleasure connected with the whole occupation was the opportunity to get out with nature, and the chance to match wits with the finny denizens of the brook. In fact, I did not always try to catch these fish. Many an hour I have fished with the bait fastened on the string in such a way that the fish could take it readily without being caught. It was great sport to dangle this bait near the surface of the water and watch the different ways the various kinds of minnows fed.

There was a shady pool at the foot of the fern bluff only a few rods from an old stone quarry where some skunks had their den. I especially liked to fish there, not because it was the best place in the creek to catch fish, but because the water was clearer than anywhere else and I could see more of the fishes' doings. Besides at this place it made one feel glad that he was alive just to look at the flowers and ferns on the bank. Since I have grown old enough 
and brave enough to go out among the wildlings without any excuse, I have abandoned both fishing and shooting for sport.

While I especially liked to fish in this pool, there was a little black, orange, and white bird which did not appreciate my presence. I never could come near this place but he began flitting about among the branches and uttering a peculiar cry of protest which sounded to me something like "W-R-R-INK W-R-R-INK."

This very active bird was somewhat similar in size and appearance to the Baltimore oriole, but lacked the golden color. He never was still for more than a few moments at a time, but was always jumping back and forth, here and there, and darting through the foliage until it almost made me dizzy to watch him. We called him the "Joree." Since I have grown up I have come more often to speak of him as the "towhee." In fact, there seem to be few birds that have more names than this fellow.

This towhee was almost always on the ground or slipping back and forth among the low bushes. He especially delighted in the willows that hung out over the creek, for there he could find plenty of caterpillars and other food and be concealed at the same time. From there he would fly to the bank under the old fernery and scratch vigorously, making the leaves fairly fly.

If you wish to identify this bird, there is no characteristic more prominent than this habit of scratching in the leaves. Few birds as small as this are at all likely to be found on the ground scratching and turning over the leaves. If you approach he slips under a brush pile at once, or slyly moves through the brush or tall weeds. In fact, he is distinctly a ground dweller. 


\section{KNOWING BIRDS THROUGH STORIES}

His nest is made by scratching a hole in the ground just large enough so that when the leaves and grass which constitute the nest are fitted in place, it will be level with the surface of the ground. It is usually placed under a bush or in a thick tuft of grass. Shreds of bark and dry leaves are piled in Sirst and then lined with dry grass, but the leaves and bits of bark are left in sight and others are strewn about until it is almost impossible to discover the nest. This usually contains four or five dingy white eggs, finely speckled with reddish lilac. The female bird's brown and white markings mingle closely with the color of the dead grass and dry leaves so as effectively to conceal the bird when sitting. Mr. Towhee is exceedingly nervous, and is continually spreading his wings and opening his long fan-like tail with a jerky motion which is very noticeable because of the white spots it reveals. I have followed these birds up and down the creek and watched their maneuvers for hours at a time. It is surprizing how many insects and grubs they eat. They eat something two or three times every minute that they are hunting, and they seem to hunt more than half of the time.

As a songster the towhee is a shining success. Few birds have more musical notes, when he wishes to sing. However, the note most common is the rasping sort of "W-R-R-INK" mentioned above. His real song is usually given from the thick leafy branches of some tree, and is more often heard in the early morning or late evening. 


\section{XXXVII}

\section{THE CARDINAL}

7 ARLY one spring morning we started from home to C. drive to Sigourney, our country seat-father, mother and I. I remember well that when we entered the great body of timber that extended from the Rock Creek bottoms to Skunk River I was interested at once, for my ear detected the whistle of a bird with which I was unacquainted. I had no sooner noticed this than father said to mother, "Hear that? "I believe that is a southern red bird." He stopped the team and we listened. Surely enough we heard the whistle repeated and almost as soon as the song was finished a streak of red flashed through the air, and a bright cardinal-red bird alighted on a branch not far from our horses' heads. I think I shall always remember that bird because $I$ was so impressed with its beauty. He was a little smaller than a blue jay and almost a uniform shade of cardinal red. He ruffled up a beautiful topknot, chirped at us a time or two, and then began his delightful love call again.

In about a month I had the good luck to accompany father and mother to Sigourney again, and we decided to take the same road and see if we could find this red bird's nest. Mother was reared in the South where cardinals are abundant and knew their habits well, and father hav- 
ing spent several years in southwestern Missouri was fairly familiar with them. When we reached the place where we had seen the bird, mother said "We ought to find the nest somewhere about here for from the way that bird was singing when we passed before, I think it likely that he had already started nest building and they almost always do their singing near the nest." Before we had time to get out of the wagon the male cardinal alighted in the tree above our heads and began scolding and fussing. Now we felt sure the nest was near, and surely enough it was not long until we noticed the little reddish brown mother sitting on the nest. The nest was in the branches of a white oak tree so near to the road and so low that by standing up on the seat we were able to look into it.

As soon as the mother realized she was seen, she left the nest and joined her husband in complaining at our trespassing. Nevertheless we all three had a good look at the nest although we did not go nearer than ten feet. The eggs had already hatched, but the young were evidently not over three or four days old. Father and mother were as much disappointed in this as I, for we had planned that if we found birds old enough to raise by hand we would take them for pets. Fearing some one might come by and see us looking at the nest and so learn of its whereabouts, we started on as soon as we heard an approaching wagon.

The nest was only about four miles from home, and we determined to return for the young birds later. We did not get back for three weeks and were again disappointed, for not only were the young birds gone but we could not find the old ones. Later we learned that an irresponsible man with his gun had come along. There are those who 
can not be content to allow a bird to live. Its very happiness seems to grate on such souls. The more rare and beautiful a bird is the more determined they are to kill it. That was the only wild cardinal I ever saw in Iowa, though once some twenty years later I heard one whistle in the deep woods. Now they are more common there.

These birds are found in abundance throughout the South, as far north as Ohio, Indiana and Illinois. They are rare in New York, Pennsylvania and New England. They range westward almost to the Rocky Mountains, a few having been seen even in Colorado and South Dakota. They are easily recognized, being our only red bird with a topknot. The female is slightly smaller than the male, and is of a reddish brown color. They are grosbeaks, and have the stout beak of this group. We have several grosbeaks, all having stout bills, broad and thick at the base, and of only moderate length. This characteristic is so well marked that if you familiarize yourself with one you should find it easy to recognize the other members of the group.

When about fifteen years ago I moved to Tennessee, I found cardinals abundant everywhere and have had the opportunity to become well acquainted with them. They do not migrate, but stay all winter in the vicinity of their nesting place. There is no more beautiful sight than a flock of cardinals on a snowy day. At that time a half dozen or more are often found together in fence rows or on the border of woods, feeding on weed seed or buckbrush berries. Their brilliant color makes such a contrast with the snow that they can be seen a long distance. At no time are they more active or apparently more happy than then. 


\section{KNOWING BIRDS THROUGH STORIES}

That is the time to make friends with them. A few crumbs scattered near the door will usually accomplish this. One winter we regularly threw the crumbs from the table a few feet from the kitchen door. It did not take long for the birds to learn this, and a pair of cardinals were the mast regular patrons of that lunch counter. Soon they were waiting in the trees that grew in the yard long before feeding time came. They did not hesitate to alight on the railing of the porch and peep in at the window if the crumbs did not arrive when they thought they should. Finally they took up their abode in our yard and nested in a cedar tree. Cardinals prefer to nest in such well concealed places, for then the mother bird is hard to see when on the nest.

The male cardinal assisted in building the nest, but then his work was done until the young were hatched. The males of many birds divide with their mates the tedious work of sitting, but not so the cardinal. The female carainal may feel very proud of her gorgeous colored lord, but the labor of doing all the sitting is the price she must pay for this luxury. Her lord is so brilliantly colored that neither he nor the nest would be safe were he to sit. He does his best to make up for this, however, by singing and whistling by the hour in some nearby tree to entertain his wife. $\mathrm{He}$ is no flirt, neither will he tolerate the presence of a rival in what he regards as his domain. Should another female cardinal come near his nest, he pays not the least attention to her; but should a male come, he attacks him fiercely and drives him from the vicinity.

The cardinal lays three, four, or five eggs that vary somewhat in color from gray to clear white. Ordinarily they raise two broods in a year. The male is active feeding 


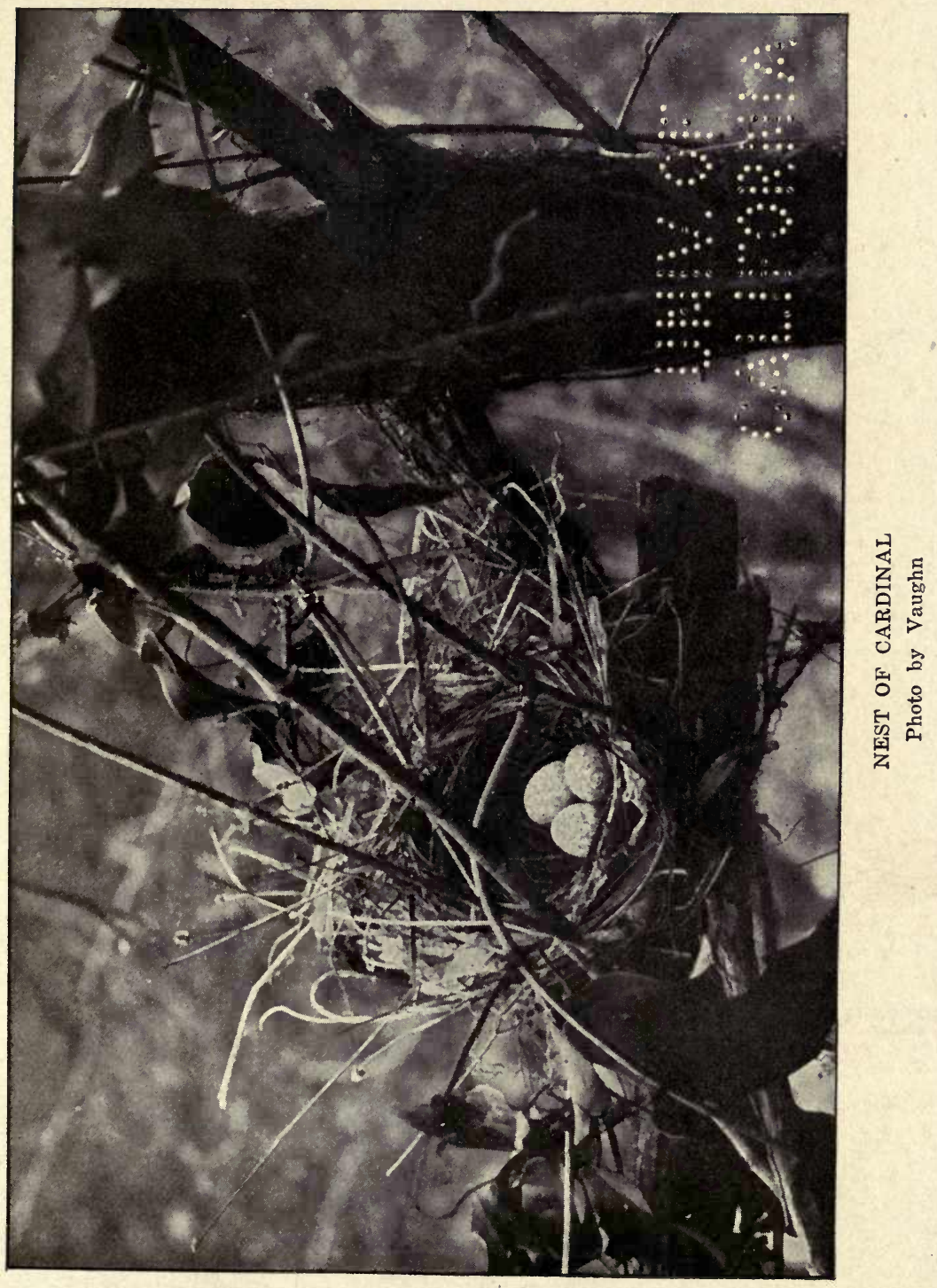




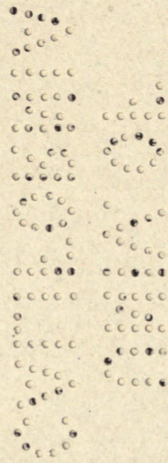


the young and attends to their training when they are able to fly.

There is no bird with which it is easier to make friends than with the cardinal. I have a friend who without thought began throwing crumbs from the table into the yard near the house. In a few days the cardinals were feeding there and of their own will almost immediately formed the habit of alighting on the window sill to beg for crumbs. Undoubtedly seeing his reflection in the glass, the male cardinal first began pecking at the window thinking he was fighting another bird, but as this attracted the attention of the family who thought that he was asking for food and provided it, he soon learned to come to peck at this window till he was fed. When insects and berries became plentiful, however, he stopped coming, though he continued to be very tame and played about on the premises a good deal. 


\section{XXXVIII}

\section{THE INDIGO BUNTING}

NE spring as I was playing in the grove I heard a strange chirp and looking up into a tree saw a new bird, a slender little fellow about the size of a vireo. This bird appeared to me to be a deep blue green, tho other people insist that his color is not green but blue. I was much interested in the little stranger because I had never heard of a green bird, so I promptly named it "the green bird." I went to the house and persuaded both father and mother to come and see my find. We were not long in locating it among the branches, but neither of them had ever seen it in our woods before. They agreed, however, that he must be an indigo bunting or, as a friend a little later told me, an indigo finch. In fact, they had both known him elsewhere. Now-a-days we call this bird the "indigo bunting."

Evidently these birds were strangers in our neighborhood, for many neighbor boys reported a new bird at about the time I saw mine and they all said it was a little green bird. They became abundant that spring and ever after were among the regular inhabitants of our grove. I have never been able to understand why birds that have not been in the habit of living in a certain locality will on a sudden move in in large numbers; but clearly that was 
the case with the indigo bunting, and from that day forward as long as I lived in Southeastern Iowa it was abundant.

This bird is not much of a songster. In fact, we never considered him a song bird at all, but we liked to see him flit back and forth among the trees because of his brilliant color. Because of his color and shape he could hardly be mistaken for any other bird. He is much more slender than the bluebird and has no red on the breast. These birds vary more or less in color, some being more nearly green, others more nearly blue. In the picture you will see a good representation of these birds, so a careful description of their appearance is hardly necessary. You will have no difficulty in recognizing them after you have looked at the picture carefully.

They prefer to live in the open places in forests, and on the borders of woods rather than in the deep forest itself, tho I have frequently seen them in the deepest woods. They feed largely on insects and are desirable birds to have about.

The nest is usually built of leares and coarse grass, well lined with fine roots and fibers of bark, and the inside is nicely finished with hairs. The birds lay three or four white eggs and usually raise two broods in a year. You will generally find the nest in a tangle of brush or on the branches of low growing trees, seldom more than four or fire feet from the ground and completely sheltered by a canopy of leares.

We have quite a number of buntings in this country, all delightful little creatures, feeding largely on insects and weed seeds or wild berries, and most of them are bright colored. We like to see brilliant colors in birds almost 


\section{KNOWING BIRDS THROUGH STORIES}

as well as in flowers. Consequently any bird that shows a brilliant color is especially welcome.

The indigo bunting is more widely distributed than the other varieties, and is 60 conspicuously colored that it seemed the easiest one for you to learn to identify. After you have become acquainted with it, you will tho more easily recognize the others, 


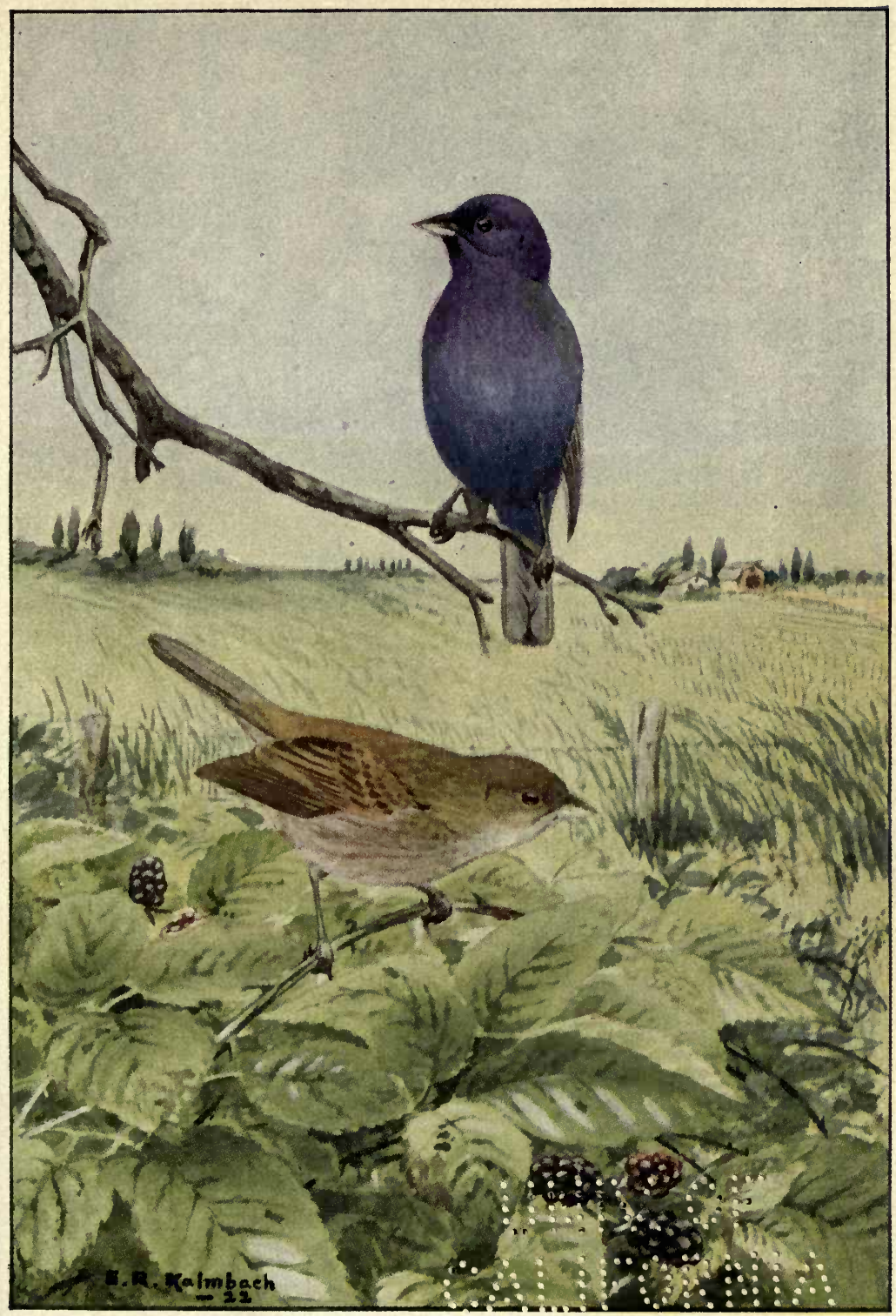

PAIR OF INDIGO BUNTINGS

Upper Bird-Male Lower Bird-Female 



\section{XXXIX}

\section{THE SUMMER TANAGER}

W HEN I moved to Tennessee one of the first things I did was to visit an old friend who had moved into the hill district of Tennessee, purchased land, and was conducting a rural school. He was working on the unique basis of earning his living from the soil and inviting the neighbors' children who had no good opportunity for education to come to his school without money and without price.

As one means of earning a livelihood he had two or three swarms of bees. Knowing that I had been interested in bees most of my life, he invited me to examine them, stating that they were not doing well. We went out and looked through his hives and surely enough I found all the swarms weak, yet I saw no evidence of disease. I could not understand this, because there were plenty of flowers near by and I could see no reason why they should not be strong and gathering an abundance of honey. I examined the hives for moths but there were none. I was at loss to understand the situation, so we sat down on a log near the bees to discuss the matter.

We had not been there long before I saw a beautiful red bird of a variety I had never known light on a twig near the bees, and while I was trying to decide whether it 
were a summer tanager, a bird of which I had heard much but had never seen, it flew in front of one of the hives, caught a bee and again lighted on its twig. In a moment it repeated this maneuver and within a few minutes it caught fifteen or twenty bees, quite enough I should think for a good meal for any bird of its size. It had hardly left before its mate, a beautiful reddish brown bird, took its place and remained until she had satisfied her appetite on bees.

This was a surprize to both of us because, while we knew that these birds feed on insects, we had never known that they catch bees. We continued to watch the bees from time to time during the day and there was a summer tanager there almost half the time. Of course this explained at once why the bees were not doing well.

We did not know how many birds were feeding there, but it was evident that there were more than two, for no two birds could possibly eat so many bees as we saw caught that day. After watching them for a week, my friend, himself something of a naturalist and a great lover of birds, decided he would have to do a distasteful thing in self-protection, so he took his gun and began shooting tanagers. The first day, he killed eight of these birds feeding on his bees. Within a few days the bees began to grow strong, showing that this had been their only trouble; and as he had killed all the summer tanagers near by, he had no more trouble.

Lest my readers should think this habit of catching bees is common to these birds I wish to say that the event occurred more than twelve years ago and I have kept bees ever since and so has my friend. Summer tanagers are so numerous that seldom a day passes without seeing 
several of them, but I have known but one other pair of these birds to bother bees.

Two summers ago a pair of tanagers made up their minds that the easiest way to make a living was to catch bees from my apiary. There were some sixteen or eighteen strong swarms of bees and as there was only one pair of tanagers making trouble, I decided to let them alone. I feared that when their young were able to fly they might train them to catch bees also, but made up my mind that when this occurred would be time enough to take drastic action. Those birds fed on bees regularly for perhaps two weeks and then began to come less frequently. Within another two weeks, while they were often to be seen flitting about in the trees near the apiary, they apparently entirely ceased catching bees. I never learned whether they tired of bees as food or whether they had been catching them in an emergency when other food was scarce.

The summer tanager is common over most of the Southern part of the United States, and is found in fewer numbers north of the Ohio river as well. They are easily recognized, as the male is practically red all over and has no crest or topknot. The only other all red bird we have is the cardinal grosbeak, and he not only has a very conspicuous topknot but is larger than the summer tanager. The only red bird that could in any way be mistaken for the bird we are studying is his cousin the scarlet tanager, the most brilliant bird in the American woods. The scarlet tanager is a more fiery red, and has jet black wings and tail.

The tanagers are slender birds, not much larger than a kingbird or a phoebe. They all feed largely on insects, as can be inferred from my story. The summer tanager 
feeds largely on beetles, caught on the wing or in trees. In fact, it seldom alights on the ground, tho I have seen it do so. It eats beetles so large that it seems impossible for it to swallow them. After these insects are digested the indigestible feet, legs, and shells are rolled into a ball by the bird's stomach and disgorged.

This bird can be heard uttering an unmusical "chickeychucker-chuck" from time to time as it flits among the branches. In mating time, however, it sings freely early in the morning - the song resembling that of a vireo, only sweeter.

The summer tanager keeps itself well hidden in the tops of trees, and for this reason it seems strange that it usually nests on a horizontal limb seldom as much as twenty feet high and often so low that one can look into the nest from the ground. This nest is built of dry weeds, etc., bound together by dry grass and is so poorly fastened to the limb and so shiftlessly put together that a high wind often shakes it to the ground.

The three to fire light blue eggs are brooded by both parents-twelve days are required for them to hatch. When the young are old enough to fly, the parents do not attempt to rear another brood but lead the young through the woods for a while and in the fall they all go south together. The young look much like the mother, but can be recognized by their hunger call-such a forlorn, pained tone as to touch even the hardest heart. Evidently they succeed in touching the parents' hearts, for the young are fed for two or three weeks after they are able to fly. 


\section{$\mathrm{XL}$}

\section{FLYGOOD AND FLEETWING}

T $\mathrm{N}$ the story of Jerry, the kingbird, I told you of two 1 purple martins that caused the death of Jerry. I think I told you that they left us, but I did not tell you what became of them. But before I give you their story let me tell you something about their family.

Martins are the largest of our swallows. Swallows are moderately small birds with long, powerful wings, and are among our most rapid flyers. When on the wing they resemble chimney swifts, tho they have differently formed feet and legs, and often alight on dead trees or other convenient resting places. They have large mouths as, indeed they must have, for they catch their living in the air.

Among the most common varieties are the cliff swallows that plaster their mud nests against the side of cliffs in the mountain country, or under the eares of the barns; the bank swallows that burrow in the mud banks of our midwestern streams; the barn swallows which plaster their mud nests inside our barns, and the purple martin, which has become almost dependent on man for its nesting place. Flygood and his wife Fleetwing, who attempted to live in my martin box, were purple martins.

After being convinced that they could not live with me 
they went to our nearest neighbor, only about two hundred yards from our house, and took possession of a new martin house that had just been put up. I became well acquainted with them, for seldom a day passed that I was not at this neighbor's from one to half a dozen times. The martin house was a two-roomed apartment, and of course Flygood and his wife needed only one. Contrary to the habits of the race, they did not invite any of their friends from neighboring colonies to move in and live next door; or if they did the invitation was not accepted. Nevertheless, this pair of martins set up housekeeping in one apartment of the house and immediately began carrying straw and grass to build a nest.

A pair of bluebirds had had their eyes on this house for some days and were highly displeased when the martins moved in. I do not know why these bluebirds had not already taken possession. They come north at least a month earlier than the martins, and ordinarily would have had eggs or even young birds by the time the martins arrived. I do know that they had been visiting this house and twittering and making a great demonstration over it for two or three days. There were three or four families of bluebirds living within a hundred yards of this particular house. No sooner had the martins entered the house than the bluebirds attacked them. One pair of bluebirds is not able to drive away a pair of martins, but no sooner had the war begun than the other bluebirds in the neighborhood came to assist. Flygood and Fleetwing held a twittering conversation, as if trying to decide what to do. They had been driven from our house and it seemed that they might have the same experience here. But they were not minded to give up so desirable an apart- 
ment without a struggle. Evidently it was settled between them that Flygood should remain and hold possession of the disputed home while Fleetwing went for help. Flygood flew back to the house, chased the bluebirds out and then, sitting with his head and shoulders in the entrance, gave battle to all comers. Fleetwing rose in quick circles and started to Lemley's, more than a quarter of a mile away, and inside of ten minutes was back accompanied by a dozen or more martins that she had brought to help.

It took only an hour or two of real battle between the martins and the bluebirds before the latter gave up the struggle, and the martins slept in the house that night. As soon as the matter was settled the visiting martins left and, so far as I know, never again paid a visit to their friends.

This impressed me very much. Evidently these birds not only knew that others of their kind lived at Lemley's, but they were able to tell them their troubles in a way to convince their neighbors that the proper thing was to come over and help.

It was late by the time these birds took possession of this house. Their neighbors had already begun to lay eggs. I presume that explains the fact that they carried only a small amount of straw and made the poorest excuse for a nest I have ever known martins to build. There was enough straw to keep the eggs from rolling about, but that was all.

These martins were friendly fellows and did not take offense when their human friends peeped into their home. Their house was on a pole only twelve or fourteen feet high and it was easy to place a ladder against the pole and see what was going on inside. The second day after these 
birds took possession of the house by noon there was a creamy white egg inside. In three days there were three more eggs, and then the mother bird started sitting, but troubles were not over.

A pair of English sparrows, among the very first ever seen in our neighborhood, decided that this martin box had been constructed especially for them. English sparrows appear to have no conscience. No matter how far the nesting operations of other birds have gone, if they decide that a nesting site is desirable they immediately set about to take possession.

These martins were busy catching insects when these sparrows arrived, entered, and decided that the location was ideal. To be satisfied of this meant to act, so these busybodies began to throw on the ground the few straws the Martins had placed in the box. Nor was this all. A sparrow had just come to the door with one of the precious eggs in her mouth when Flygood circled near enough the house to see what was going on. With a chatter of anger, he flew like a bolt to the nest hole, entered, and catching the sparrow by the back of the neck, backed out of the door and shaking her angrily, flung her to the ground. By this time his mate arrived and joined in the melee. The sparrow which had been so peremptorily thrown out was not hurt in the least but merely infuriated. For some time there was a battle on and about this martin house; but in spite of all her pernicious ways, the sparrow is no match for the martin when numbers are nearly even. The sparrows had to leave the martin box, and they took up their abode in the wind-mill tower nearby.

The martin is a strong fighter, but he is not spiteful. When the matter of possession of the nest box was settled, 
they paid no further attention to the sparrows. But English sparrows are mean-spirited and carry a grudge. For weeks these sparrows lost no opportunity to slip into the martin box and commit any depredation they could. This made life strenuous for the martins. Flygood did not attempt to help brood the eggs, but perched on the martin box much of the time watching for the sparrows. Half a dozen times a day it was necessary for Flygood to chase them away. He sometimes left long enough to secure food, and he even carried food to his mate at times; but usually she left the nest and went for food on her own account. At these times Flygood never left the precious nest more than a few feet. Even then he often had to use strenuous efforts to protect the nest. While ordinarily only the female sparrow came to the martin house, one day when the mother martin was away bathing or gathering food the male sparrow came and drew Flygood away in pursuit while his wife slipped into the nest. She threw another egg out of the nest only a day or two before it would have hatched. These sparrows were not now fighting for a nesting place. They had a nest and eggs of their own. What they did was done apparently out of mean-spirited spite.

After that day's experience the martins kept more careful watch than ever over the house. The experience of having the female sparrow break an egg while he chased her husband taught Flygood a lesson. Now he never chased a sparrow more than a few feet before he returned to the house to make sure that its mate had not slipped in during his absence.

When the young hatched, new difficulties presented themselves, for they must be fed at all hazards, since starvation was even more to be dreaded than sparrows. Per- 
haps it was fortunate after all that two of the eggs had been broken, for now there were only two baby mouths to fill, and it seems that young martins are all appetite. No matter how often they are fed, they are always ready for more; and in spite of all the parents could do, those babies were always ready to accept hard boiled egg or small grasshoppers at my hand. By the time they were a week old, they were too large for the sparrows to injure, and both martins and sparrows seemed to recognize this. So both parents were free to hunt, and it was only a few days till both seemed to show more vigor of flight than when they were living the strenuous life necessary to safeguard the home.

The old spotted cat which, like most of her tribe, sometimes caught birds, but seemed to be particularly fortunate in catching only those I was glad to see destroyed, went down to the neighbor's, climbed the wind-mill tower and caught the sparrow on her nest. She not only made quick work of the mother, but devoured the five young birds as well; and this ended the martins' trouble from that source.

Not only had the martins guarded their nest against the sparrows, but they were almost as active as Jerry the kingbird in chasing and keeping hawks and crows from their neighborhood. Because the martins are such fighters they were favorites with our American Indians. Before the white man came to our shores, these people made it a practise to cut holes in the side of large gourds and hang them in the trees near their village to attract the martins. The birds in turn protected from buzzards and hawks the deer skins and other pelts which were stretched on the trees near the Indian camp during the tanning process. 
Probably the early settlers got the idea of building martin houses from the Indians. Whether this is true or not, a colony of purple martins living in a yard is a more effective protection against hawks than half a dozen shotguns; for man is usually either too busy or too stupid to see a hawk when it comes, but these sharp-eyed birds are always on guard, and seldom indeed can a hawk slip into the yard and catch a chicken while these birds are about.

The young birds had been out of the nest at least two weeks before the old birds ceased feeding them. Even then they slept in the home nest every night.

The mother bird laid five more eggs as soon as these youngsters could fly and their sleeping in the nest never seemed to concern her in the least. Doubtless they were careful not to break the eggs or to injure their younger brothers and sisters when they hatched. They occasionally entered the box in the day time, but I question whether they fed their young brothers and sisters. With many birds one could easily have settled this matter by watching, for had they done so they would have carried the food in their bills; but martins swallow their prey and then thrust their bills down the young bird's throat and there disgorge the partially digested food. The feeding always occurs inside the house, so mere man cannot tell whether a bird that enters the box feeds the young or not.

When the second brood of young were able to fly, a third clutch of four eggs was laid. By this time sleeping quarters were crowded at night, for the five eggs of the second clutch all matured into fully-grown birds. All seven of the young birds crowded into the nest every evening, but their parents slept next door. It would have seemed more in keeping with our ideas to send the older children 


\section{KNOWING EIRDS THROUGH STORIES}

next door to sleep; but I have no disposition to criticize the housekeeping methods of my little neighbors, especially as every one of the third clutch of eggs hatched and all lived ito maturity. By the first of August there were thirteen martins living in this house. With no family cares, they now roamed over orchard and meadow, sometimes flying as far as the neighbors which had rendered them such valiant assistance in the spring.

Toward fall the weather became dry and the only convenient watering place was the brook near our grapevine playhouse. There these birds came several times every day for a drink or a bath. A thirsty martin would circle back and forth near the surface of the water, every few moments dipping her open bill into the water and scooping up a mouthful. In bathing, they fly close to the surface of the water and then dive, and, coming up again, continue their flight almost without checking speed. Round and round they circle, dipping and splashing for an hour at a time, probably getting the water to the skin in places; but I have never seen them become thoroughly soaked, as most birds do while bathing.

When the last of August came and frost might be expected soon, they changed their habits. They would sit for hours on the comb of the house or the limbs of an old dead tree, chattering and preening their feathers. Undoubtedly birds find it necessary to have their bodies in good condition before they start southward. At any rate, every feather was oiled and preened a hundred times during the ten days' gathering preceding their departure. Almost every evening the birds would fly to the similar council that was being held in the neighbor's orchard a half mile away, tho they never remained long at a time. Two or three days before leaving they began to act 
strangely. All would be sitting in the gathering chirping and preening their feathers when suddenly one would utter a peculiar twitter and instantly every bird would leave its perch and start rapidly southward; but after flying a hundred or two yards one always heard the rallying chatter and all returned to the gathering place again.

It would be interesting indeed to know all that went on in those days preceding the journey south. Some people believe the parents were instructing their young in the maneuver of starting together and keeping together in the long flight.

At that time they never went near the martin house except to sleep. Undoubtedly there was more or less vermin there and these wise birds meant to get their bodies entirely clean from troublesome pests before going to the warm tropical regions where the vermin would cause annoyance all winter through. Half or three quarters of an hour before sundown these birds would leave their perch and begin circling round the old nest every few moments, twittering as they went, then circle back over the orchard or meadow for more insects. Shortly after sundown these circles would grow smaller and finally some bird would enter the house. The next time they came by perhaps another would do the same. Then within a few moments every bird would dart inside and things would become quiet for the night.

Early one morning this flock of birds was holding its gathering in an old apple tree in our orchard perhaps a hundred yards from the nest. Suddenly the parent birds gave the signal which to my ears sounded exactly like the signal they had been giving a score of times each day for a week, and the whole flock started toward the south; but this time they did not return. They had not gone very 


\section{KNOWING BIRDS THROUGH STORIES}

far before I was convinced that they had really started southwards, for I did not hear the return signal and not one bird showed the least disposition to circle or look back. Gazing after them, I saw them meet the much larger flock from Lemley's and all passed out of sight over the southern horizon.

These birds sometimes gather in large flocks for the journey. Often all the purple martins within miles meet at a common point, and together take their flight. The departure is always in the morning and, as far as my observation goes, before ten o'clock.

Some naturalists claim that a few sentinels return to the northland as early as the middle of March to spy out the land and see if the old nesting places are in order. In the southern part of the United States they are sometimes seen in flocks of tens of thousands on the northward journey. At that time they move leisurely; but when spring really comes in the north they usually appear at practically the same time over a considerable area of territory and begin nest building at once.

If there are martins in your vicinity and you will construct a proper house and mount it on a pole the day the martins return to your neighborhood, you will very likely find it inhabited within three or four days. Should you put it up earlier than this, bluebirds are likely to take possession of it before the martins come; once they are in possession, the martins are not very likely to drive them away. No bird is of more value to us human folks than martins, not only because they drive away crows and hawks, but because they feed largely on flies, ants, and other injurious insects.

Watch for the martins and learn to recognize them. 


\section{XLI}

\section{THE CEDAR WAXWING}

NE day early in spring my sister and I were in the woods hunting for the first bloodroot and anemone blossoms when we heard a "twee twee" among the bushes. Looking around we saw a flock of a dozen or more beautiful little birds feeding on buck-brush berries.

I had never known anything to eat these berries and of course was surprized to see these birds feeding as merrily as if at the banquet of a king. There is one thing I admire about birds. Tho a certain article of food may not be to their liking, if circumstances force them to eat it they feed as cheerily as if eating the fat of the land.

The thing that impressed me about these birds was the beautiful crest or topknot, as we call it. The head, neck, and breast were a beautiful brown color, and when they raised their crest it reflected a beautiful purplish sheen. The body was olive-gray shading to ash color on the rump and to yellow underneath, the tail coverts shading to a blackish color in the tail itself, which was tipped with yellow. The wings, especially when spread for flight, showed sealing-wax red tips to the feathers.

They did not swallow the berries whole, as I had expected, but cracked the seed with their strong beaks and ate only the kernels. These were so small that it was no 


\section{KNOWING BIRDS THROUGH STORIES}

wonder they had to keep busy in order to secure a good meal. Occasionally one would find a grub or an insect which he ate greedily.

Fortunately my sister knew these birds. They were cedar waxwings. She said that they feed on cedar berries, especially in the winter. I have seen them doing this many a time since.

As we watched these birds, a swarm of mosquitoes came dancing through the air and immediately these birds began catching them. Flying back and forth through the swarm they followed it until it passed into the bushes where the members of the swarm could not be easily caught. I came to know these birds well in later days, and there is no bird with which I am acquainted that is more active in catching flies, gnats, and other flying insects than the cedar waxwing.

When the crane flies emerge from the meadows in the springtime, these waxwings catch them by the hundreds. In his notes on birds of Minnesota Dr. Hatch quotes a Mr. Washburn as stating that one day in August in the Red River Valley of Minnesota he watched a half dozen cedar waxwings hovering over a slough and catching insects. He states that these birds were on the wing constantly for almost half an hour passing back and forth among the insects which they caught steadily. He says that not once during all this time did one of these birds alight and for the most part they were so busy that they did not even take time to utter their characteristic notes.

When our cherries were ripe I saw my first dead waxwing. We had a number of cherry trees and ordinarily allowed the birds to eat all they wished without let or hindrance. That spring father and mother gave consent for 
my older brother to shoot certain birds that were eating cherries, and having a new twenty-two caliber rifle he was not slow in acting on the permission. Robins, red-headed woodpeckers, cedar waxwings, and blue jays were the worst offenders, but robins were not to be killed. The slaughter continued for only one forenoon, however, and perhaps no more than fifteen or twenty birds were killed. Then my brother himself decided that it was cruel to kill birds simply because they liked cherries, but he did not come to this decision till four or five cedar waxwings had been killed.

This bird measures seven and a quarter inches from the end of its bill to the end of its tail, and as the tail is considerably less than three inches long the body is of fair size, not quite so large as the butcher bird's, but yet quito plump. Many farmers slaughter these birds without mercy because of their love for cherries. Few seem to know that they have any good qualities to offset this weakness. If they were to become better acquainted with them, however, they would find them among our best insect-eating birds. True they eat berries of various kinds, but most of the berries are wild. They eat a great many seeds, but not grain, and the few cherries they devour are paid for many times over by destroying insects.

I presume the thing that most prejudices people against these birds is their gluttony. They will eat any berry, fairly gorging themselves on fruits that no other bird eats, often continuing until they can not fly. They seem greatly to enjoy their food, erecting their topknots and moving their wings as they eat, and in every way showing keenest enjoment. The are persistent when feeding, so much so that it is often difficult to drive them out of a cherry tree. 


\section{KNOWING BIRDS THROUGH STORIES}

Ordinarily they are cautious. They fly in droves, often circling several times to make sure all is safe before alighting; but when once they are convinced all is well, they pour down all in a heap. Then they scatter and begin feeding.

They nest on a low horizontal limb, preferring an apple tree. They build the nest largely of coarse grass, lining it with finer grass and tie it to the limb securely. They lay four purplish white eggs speckled with black, more so at the larger end.

When the nest is disturbed they are seldom seen, as they quietly slip away at the first approach of danger and remain away till the danger is past. 


\section{XLII}

\section{THE BUTCHER BIRD}

A LITTLE less than a quarter of a mile from the old A farm house on the east edge of our farm stood one of the first three orchards set out in that part of Iowa. Most of the trees had originally been seedlings, but father, with the skill of most pioneers, had top-grafted them and many of them were as large as forest trees and bore apples as good as could be found anywhere. The field where the orchard grew was usually planted to corn, even the orchard being cultivated as tho no apples were there. This field had an osage orange hedge on all sides, but on the north there were occasional holes where the cattle were wont to break through. To prevent this two or three strands of barbed wire had been stretched through the hedge.

In apple time sister and I were often given two sacks and sent to this orchard for a load of apples. This was always a delight, for there was never any hurry, there was always an abundance of delicious apples to be eaten, and when one no longer had room to eat there was plenty of time to fill the sacks. In the hedge fence near the old Shaker Yellow apple tree was a bird's nest of a variety whose name we did not know. The nest's owner was somewhat larger than both the phoebe bird that nested un- 
der the cattle shed and the catbird that nested in the pippin tree, but it did not much resemble either. It was a beautiful bluish gray with black wings and tail, and always looked so fresh and clean that we were fond of it. The nest was placed so low that by standing on an old barrel we could see the eggs and watch the young birds. These birds were not shy, and were always on the watch about their nest, tho they did not make any such outcry when we came near as did mother catbird.

They nested there year after year, seldom locating the new nest more than fifteen or twenty feet from the old one. They and their nest form one of my earliest recollections, and when I left home at sixteen to enter college they were still nesting in the old place, so of course I knew them pretty well. With a cornfield on one side, a pasture on the other, and a neighbor's oat field within a hundred yards, food was always abundant. True, these crops sometimes alternated, but they were always there. Those birds fed on grasshoppers and beetles, with an occasional mouse for dessert, so they could have had no better hunting ground.

I had known these birds for a number of years when one spring I began to find grasshoppers and beetles impaled on hedge thorns or on barbs on the wire near the nest. These insects were stuck so that they could not wriggle loose, and yet were not hurt seriously enough to die for some time. Once or twice I found a mouse securely stuck on a barb by the skin of his back, wiggling and twisting in a vain attempt to get free. This appeared to me cruel and horrible, but I had no idea who was doing it. I knew that small boys had been coming to the orchard for apples, and $I$ thought they were amusing themselves in 


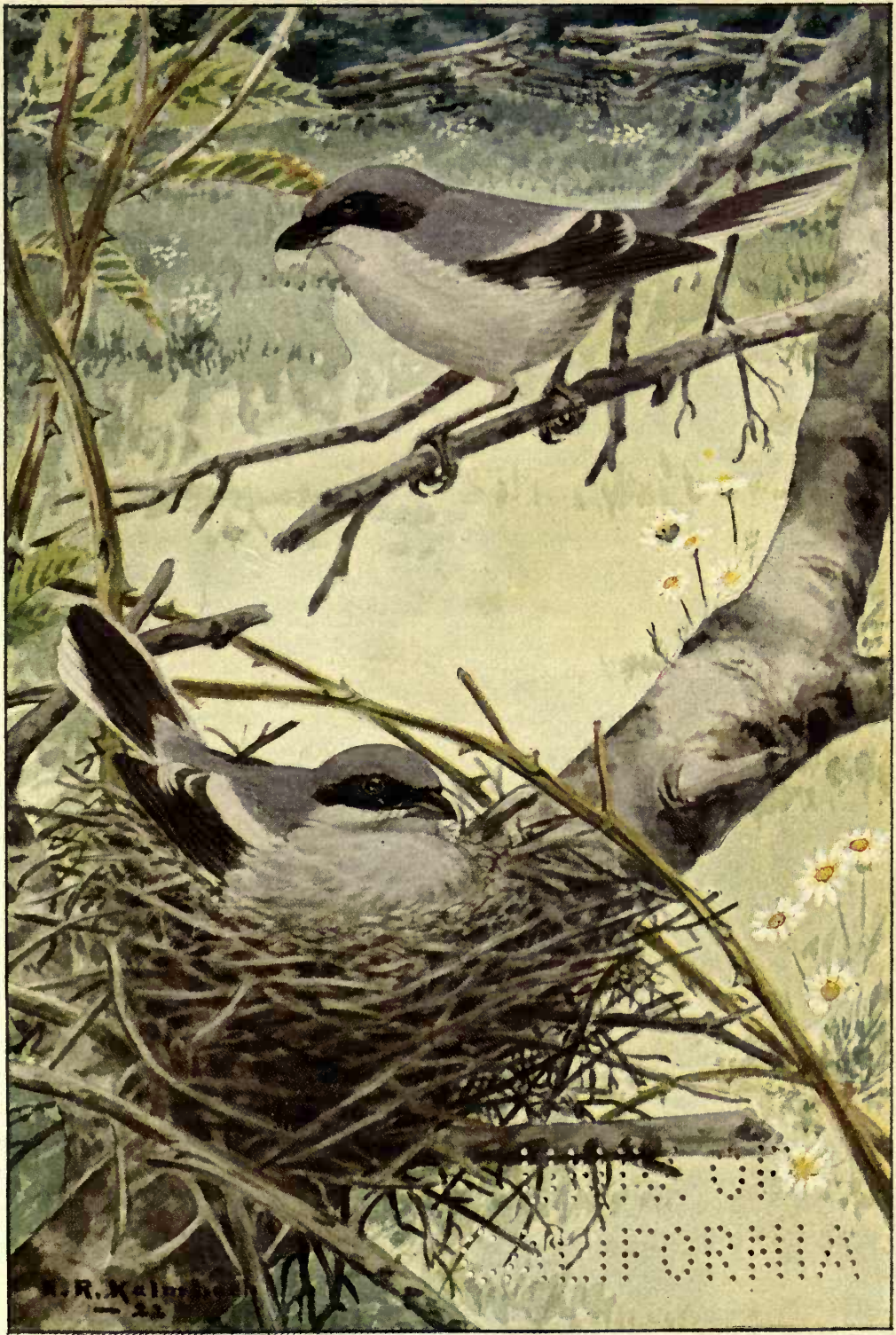



this way. We did not care about the apples as there were plenty of them, but I did care about this cruelty. I made it my business to release every poor creature $I$ found impaled in this way, and either to turn it loose or, if it appeared too badly hurt, to end its suffering by killing it. I became so indignant that I finally appointed myself a committee of one to discover the culprits, and one day discovered them. To my utter surprize these birds were guilty. The situation was this : it had been a cold spring, and grasshoppers and other food were scarce. Ordinarily these birds could catch an abundance of food whenever they desired, but this year it was different. It often took a long time to find food, but early in the morning when the grasshoppers were cold and stiff they could be caught easily. These birds would not eat decayed or tainted meat of any kind if they could help it, and they did not know how to build coops or pens. Clearly this was the only way they knew to keep a supply of live, fresh meat always on hand. As the summer wore on the insects became abundant, I found no more poor creatures stuck on the thorns and barbed wire.

When I made these discoveries, I renewed my efforts to find out what birds these were. Finally some one in the neighborhood said they were called "butcher birds" because of the cruel way they had of sticking mice, small birds, etc., on thorns merely for the fun of watching them die. Since then, I have learned that this bird's true name is the migrant shrike; and that there is a large family of shrikes all looking much alike and having practically the same habits. In regions where this bird is abundant, it is common to find small creatures impaled on thorns and barbed wire. I am aware that many who are very familiar 


\section{KNOWING BIRDS THROUGH STORIES}

with the shrike's habit claim that they impale these poor insects for the fun of killing, and that they never return to them afterwards. This may be true, but it certainly Fias not true of my birds. I have many time seen them return and eat insects they had impaled, and have even seen them feed these to their young.

My friend, Professor A. C. Holt, dean of Tusculum College, tells me that when he was a boy he knew these shrikes very well, and that he never knew them to impale creatures for amusement merely. This corresponds to my own experience, for I had known these birds for several years, seeing them practically every day and spending hours in the vicinity of their nests, before I discovered any such habit. Cruel, you will say! Yes, but no more cruel than for fisherman to string their fish on a line or a string of bark passed through the gills and to leave them for hours or even days in the water, where every breath is torture while they also suffer for lack of food. Nor is it more cruel than the way we handle chickens in our markets.

The shrike is accused of robbing other birds' nests, and I presume in an emergency he does so; but I have seen as many as three or four sparrows' and other small birds' nests within a hundred feet of my shrike's nest and none of them were ever disturbed; moreover the mother birds showed no alarm when the shrike happened to alight near their nests. I am convinced that shrikes feed entirely on live insects and mice when they can get them. If the food supply runs short, they store a supply when they make a lucky find. If food should become even more scarce and a bird's nest happened to be near, I do not doubt that they would eat the young birds. Doubtless for this 


\section{THE BUTCHER BIRD}

reason they deserve the widely spread common name of "butcher birds," but nevertheless they are a benefit to the farmer. Nesting as they do in well protected places near the fields they devour a large number of field mice, and surely this is good service. 


\section{XLIII}

\section{THE RED-EYED VIREO}

7 HE first thing I usually hear of a summer's morning

1 (if I waken at the time I usually do, just as the first streak of dawn appears in the east) is the song of the red-eyed vireo, tho at home, where we had plenty of robins, they used to begin singing as early as the vireos. In fact, it was a race between these two birds to see which would get up first, sing his morning hymn, and catch the early worm.

From the fact that the vireo is one of the first birds to sing in the morning, it becomes fairly easy for one who is willing to get up early to identify him. He proclaims his name as plainly as a bird can do. His melody is scarcely worthy of the name song, nevertheless it is a pleasing and cheerful role and seems to express entire satisfaction on the part of the bird himself. It is a "vireovireo-viriee-vir-'a-viree," uttered energetically but with a tendency to drawl the words a bit.

As the day advances, by nine-o'clock the robin is usually through singing and does not resume till evening. Not so with the red-eyed vireo. He sings all day long. But tho he sings almost constantly, he is usually heard rather than seen. His small size and dull color help to conceal him and he generally manages to keep himself 
hidden in the trees and brush. He not only prefers to live in trees, but chooses the tall leafy ones where he flits about among the topmost branches.

He feeds largely on the caterpillars, flies, and other insects in the tree tops, hence has small need of coming to the ground. If you watch a vireo carefully, you will see him moving back and forth on a limb, reaching for insects first on one side and then on the other, stretching his neck and legs until you would almost think they are made of rubber. He hunts over the limbs from morning till night, stopping every few moments to sing his thankfulness for his delightful home. He is such a lover of the trees that he sometimes even drinks the dew and raindrops that cling to the leaves and branches.

I have found the red-eyed vireo's nest in a clump of small bushes within two feet of the ground, tho more often they build in trees some ten or fifteen feet high. The nest is rather characteristic, being a half hanging nest. Where it can be obtained, the mother bird peels off the tough inner bark of the red elm or of the willow, sometimes using the tough fibers of the previous year's "cotton weeds," and weaves the body of the nest from this tough fiber. As soon as this is woven so that she is assured of plenty of strength, she mixes in other materials, such as soft grass and fuzz from various seeds. Bits of hornets' nests or pieces of paper are often used not only to make the nest soft and cozy but because the dull colors are effective in helping to conceal it.

The eggs are glossy white but are slightly speckled at the large end with reddish brown or chocolate. Four is the most common number, altho it is not unusual for the bird to lay only three. When the young are able to leave 


\section{KNOWING BIRDS THROUGH STORIES}

the nest they follow their parents, all hunting together for a long time. The vireo usually rears but one brood in a season, feeding the young birds for some time after they leave the nest.

We have many kinds of vireos in America, but the redeyed is the most widely distributed. They are all small birds, the red-eyed being about six and a quarter inches long from the end of the bill to the tip of the tail, two inches of this being taken up by the tail. The bill is pointed, and the entire bird is a trim, slender little creature. The back, rump, edges of the wings, and tail feathers are of bright olive green, rather more olive than green. The sides of the head and the neck are paler. The top of the head is a dark ashy color sharply edged by a dark line. A white line just below this dark line runs from the bill across over the eye nearly to the back of the head. The bird is white beneath and often shows pale sulphur yellow under the tail. All of the vireos are delightful birds, and are especially valuable in that they feed almost wholly on caterpillars and insects with a few weed seeds.

From the key you can learn the family characteristics, and you ought to be able to find three or four kinds of vireos in your vicinity. The red-eyed vireo, of course, has a red eye, which is one means of distinguishing it from its fellows. 


\section{XLIV}

\section{THE YELLOW WARBLER}

AONG our small birds, of which we have such great A numbers, there is none more commonly known and more widely distributed than the yellow warbler or, as it used to be known when I was a child, the summer warbler. It comes flocking North in the early part of April and stays with us till late fall. It is one of the birds that seem to come all at once. We children used to watch eagerly for the first bluebird or robin, and then expect it to be several days before we would see another, and usually two or even three weeks would pass before they became common. This was not true of the yellow warblers. When you saw one you could expect to see others right along, and they were among the most numerous of our small birds.

There is a large family of the warblers, and it may be rather difficult for the beginner to learn to recognize them. In the key you will find the characteristics of the family and by becoming acquainted with two or three warblers, it will be easier to recognize the others. We have chosen to tell the story of the yellow warbler not only because it is plentiful over more of our country than any other but because it is one of the easiest to recognize. It arrives in the spring ahead of most of the small birds, and this makes it still easier to recognize. 
There are several peculiarities by which this bird can be identified if you can get near enough to see it well. Its bill is lead-colored, while its head and under parts are yellow-not a dull but a really bright yellow. The back and the rest of the upper parts are a dull yellowish green, brightest on the rump. In some birds the back is more olive than yellow. Sometimes there are streaks of dusky reddish brown on the back, while the breast and the sides of the body are always streaked with brownish red. The tail feathers are dusky, except part of the web, which is yellow. The wing feathers are dusky, edged with yellowish green, while there are two narrow bands of yellow on the wing.

They mostly frequent the thickets and edges of woods, but can be seen almost everywhere. While they have a charming little song, they are by no means great songsters and perhaps would never be noticed for their song alone. In fact, after the other birds have come North and the woods are one grand chorus of music, a person hardly notices the song of the yellow warbler.

This bird must not be mistaken for the goldfinch, which belongs to an entirely different family. The male goldfinch is yellow excepting the top of the head, tail, and wings, which are black, while the general appearance of the yellow warbler is that of a truly yellow bird. He is also much more slender than the goldfinch.

What this bird lacks in song he makes up in mechanical skill. Sometime between the first of April and the middle of May he constructs one of the best-made nests of any of our birds, without doubt the very best of any of our warblers. It is almost always placed in the forks of a bush, the site being selected so that it can be fastened to several 
small branches. Where everything is as it should be, the nest is built three to five feet above the ground. Weeds form the framework, and any other good nesting material that can be easily found constitutes the filling. Bits of wool, dead wood, horsehairs, cow hairs, feathers-any such material is carefully woven to the sticks with the long tough fiber peeled from the wild grapevine, or if the grapevine cannot be found, with fine roots or tough dry grass. The nest is much larger than would be expected of so small a bird, because he takes the trouble to make the walls very thick. Building as he does just at the time that the cotton is flying from the willows and the cottonwoods, a great deal of this silky down is woven into the lining. Early thistledown is occasionally gathered and used. When the nest is finished it is as cozy inside as a carpeted parlor, and the builder might well be proud of his job.

The eggs are greenish white, heavily spotted with brown and lilac, the spots sometimes running together into splotches. The cowbird seems to take especial delight in laying her eggs in the nest of the yellow warbler, doubtless in part because it is so well built. This bird often selects the nest of some small birds so that her young will be more lusty than its fellows.

The yellow warbler may raise two broods or may be content with only one, according to the part of the country in which it lives. Those that go farthest North probably raise only one brood. Like most of the warblers, its food consists largely of insects and weed seeds, and so this bird is truly a friend of man. 


\section{XLV.}

\section{THE YELLOW-BREASTED CHAT}

T $N$ the story of the crow I told you about the clump of 1 blackberry bushes, giant ferns, etc., that grew hard by the crabapple thicket and that tradition said was a snake's den. No one tramped through this thicket and so it had grown so thick with blackberry briers and gooseberry bushes that it would have been difficult to crowd through it. But in spite of supposed snakes and thick brush few things went on in this thicket without our knowledge. As you remember we children played on all sides of this thicket, because it was only a few steps from our favorite playhouse, the wild grape arbor.

One day early in May sister and I were playing in the grape arbor when we noticed a pair of birds that were different from any with which we were familiar. They were fair sized birds, about seven and a half inches long, of uniform olive green color above while the breast and under coverts of the wings were bright jellow, and the belly white.

These birds stayed pretty close in this thicket, tho they did not hesitate to enter the crabapple thicket or the gooseberry bushes near by. They did not go into the open woods, however, seeming to feel safer in the thick brush. The male evidently had not finished courting his wife, 
for as we watched them he went through the queerest courtship we had ever seen. He would sing and parado before his lady love, evidently doing his very best to please her, yet his every act, even his voice, gave the impression that he was scolding her with all his might. He gesticulated with every note, sometimes jumping into the air and alighting again, now hanging to a twig with his head down, now performing some other maneuver, but always moving his body with every note uttered. He seemed to be in a perfect delirium of song, but his antics appeared anything but graceful to us. Every few minutes he hopped into the air, sometimes to an altitude of eight or ten feet above the female, his feet and legs dangling at full length and his tail jerked up and down until we had to laugh at his awkward appearance.

Evidently the lady of his choice failed to see anything ludicrous in this performance, for the very next day they. began building a nest. This nest was placed not more than two feet from the ground, in a wild gooseberry bush toward one edge of the thicket. It was perhaps six or. seven inches in diameter, built mostly of dry leaves and sticks, bound together with strips of bark taken from our wild grapevine and grass collected from under the hedge near by. It was firmly placed, however, and was neatly lined with horsehairs and a few small willow roots.

The nest done, the male bird again took up his song and continued to sing from time to time for a number of days. His song sounded as peculiar as his antics looked. Perhaps it can be best described in the words of Audubon, that matchless student of birds. He says of its song, "Sometimes the sounds are scarcely louder than whispers, now gain strength, deep gutteral notes roll in slow succession 
as if produced by the emotion of surprize then others clear and sprightly glide after each other, until suddenly, as if the bird had become confused, the voice becomes a hollow bass." I can compare it to nothing so well as to the voice of a boy who is just changing from childhood to manhood.

In a few days the eggs were laid, five of them, of a flesh color spotted with a reddish brown. When four eggs had been laid we happened to notice these birds making a terrific fuss about the nest. We knew that something was wrong, so ran over to find what it was.

A large blue racer snake had crept into the gooseberry bush and was just ready to help himself to the eggs. The distressed birds were fluttering about, striking at him and using every means within their powers to prevent his stealing their precious eggs. Now we were sure this thicket was a snake's den, but for all that we mustered up enough courage to get a long stick and chase this snake out of the bush. We were afraid he might return and rob the nest, later, but either snakes do not remember as well as do crows and many other wildlings, or else we gave him a thorough scare, for the next day when we examined the nest instead of all of the eggs being gone there were five instead of four. The mother bird began sitting at once and in twelve days there were baby birds in the nest. Two broods were raised that summer.

While I did not have the opportunity of becoming acquainted with very many yellow-breasted chats when I was a boy, I have found them frequently since and they almost always live in low brush and tall weeds. The thicker the brush and the more difficult for a human to get through the better they are pleased. Nesting as they do in places that 


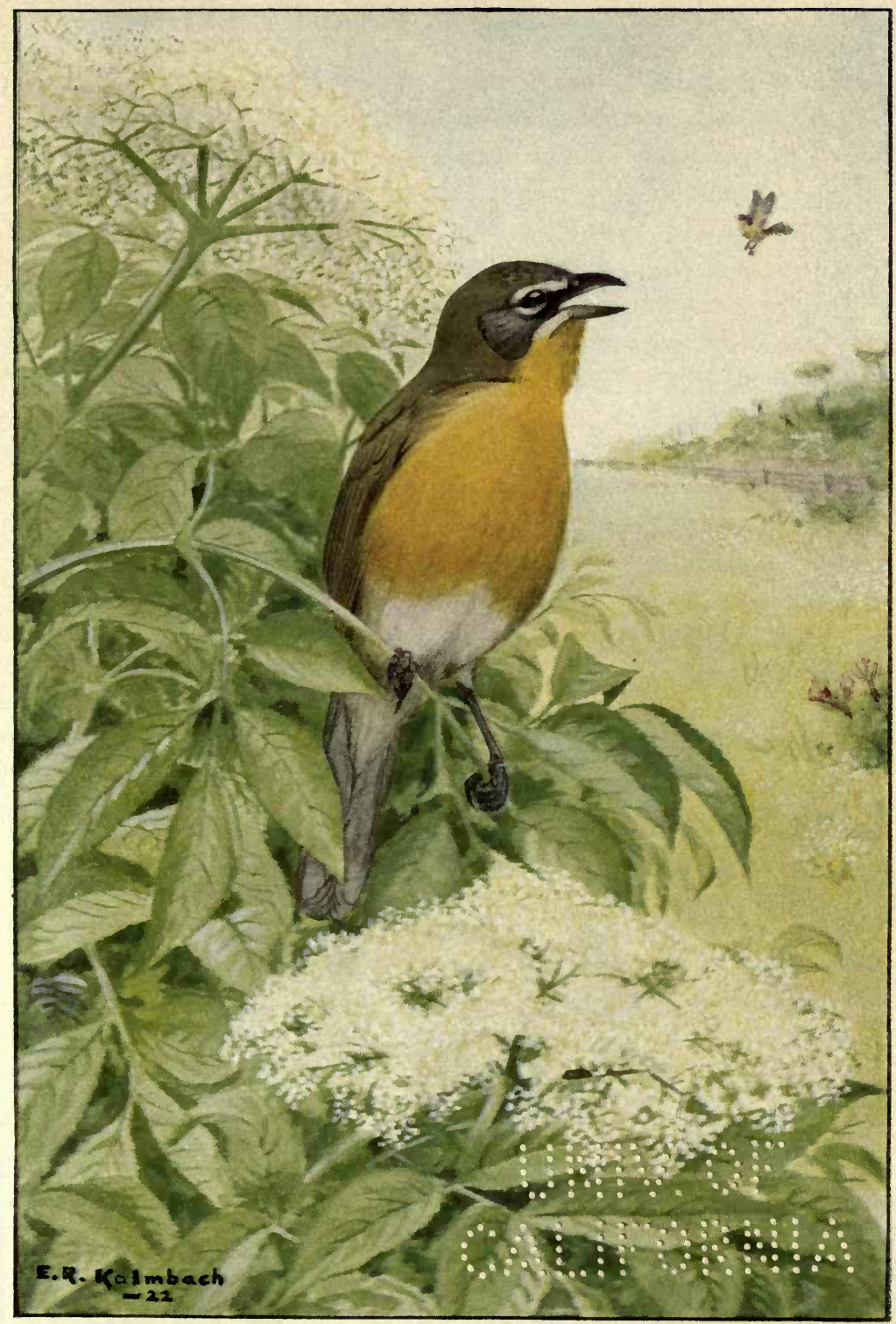



are frequented by snakes, and placing their nests so near the ground, it is no uncommon thing for snakes to eat either the eggs or the young birds. The parents are fearless, however, and doubtless sometimes succeed in driving the snake away.

If a dog passes through their thicket they do not hesitate to follow him, scolding and manifesting their distress in every possible way, and I have even seen them pounce on the dog's back and peck and pound him with their wings.

These birds feed largely on beetles, caterpillars, and other insects, tho they are fond of wild fruit, especially strawberries. Wild strawberries are apt to grow in brush such as they inhabit, and from their great fondness for this fruit I have sometimes thought this might be a deciding factor in selecting their home. I have never seen them do damage in orchards, however, so no one should begrudge them the wild berries they eat.

They are found over the greater part of our country, tho one must go into the sort of places they inhabit in order to find them. 


\section{XLVI}

\section{THE MOCKING BIRD}

A S I write I am usually entertained all day long by - 1 a mocking bird in a tree near my window. If I feel blue or disgruntled in any way, all I have to do is to listen to this bird for a few moments, and the gloom disappears and the world looks bright again. Unfortunately some of my readers have never seen this most remarkable of songsters, but wherever it is known it has always been greatly loved.

There is a legend that once upon a time the birds were discussing which was the best singer. The argument waxed loud and long until at last the wise old owl suggested that they have a contest. Each bird was to sing his sweetest song and then all should rote as to which was the master musician. Through all this discussion the mocking bird remained silent, but no one seemed to notice this until the contest began. The lark, the robin, and the nightingale, the whippoorwill, the blue jay, and the wren-in fact, all the birds-in turn sang their loudest and best till all were done. Then some one discovered that the mocking bird had taken no part at all. One after another demanded the reason, and finally were met with the reply that he had no song. At last, after much urging, he came forward, chirped a bit, and then sang the song of one bird after 
another until he had sung the songs of all. When the vote was taken he was chosen by common acclaim the greatest singer of them all, for all acknowledged that not only could he sing as well as others but could sing their own songs better than they themselves could sing them.

This legend isn't so far from the truth, for while the mocking bird really has no fine song of his own, he is the greatest mimic in the world.

For a number of years a mocking bird nested within a few yards of my window. We became well acquainted, and a wag he proved himself to be. In the springtime, when the mother is breeding, the mocking bird seems too happy to think of anything but song. All day long he sits on some limb and sings his heart out. Thus far he is not much different from other birds, but when the sun goes down and most of the others creep off to sleep, the mocking bird seems to feel that it is his duty to make up the deficiency by singing all the longer and louder. Any time that I waken during the months of April, May, and early June I can hear my mocking bird singing, and it is in the night that he manifests his roguish spirit most clearly.

I used to raise Chinese geese, and in the springtime usually had a few valuable goslings about the house which I always shut up carefully at night lest disaster overtake them. I never knew how friend mocking bird learned of the great interest $I$ took in these goslings, but certain it is that before they were a week old, about the time I would fall into the soundest sleep I was sure to be awakened by the voice of little goslings. I would listen a while doubting my ears and trying to distinguish some false note, but usually ended by going out to catch my stray goslings. Sure enough the noise would be coming from 
the grass and I would follow it a few steps and then stop to listen. The sound always seemed only a few feet away, but strange to say every time I thought I was getting near, it would come from some place a little way beyond. After the bird had led me about from place to place for five or ten minutes, the last "peep" was pretty sure to come from a tree straight overhead and would be followed by the cackle of a guinea or the bark of a dog, and I would remark to myself, "stung again!" Nevertheless the next night my anxiety usually got the better of my judgment, and I would feel sure that that time a gosling had actually gotten out.

A little later in the season there was a brood of baby bronze turkeys about the house for a few days, and we had our performance over again practically every night, except that Sir Mocking Bird chose to imitate a baby turkey rather than a gosling that had now grown too large to need care.

A little later I bought an Angora cat which raised me a few broods of kittens. Now my mocker was in the height of his glory, seeming to realize that the safety of a kitten meant a great deal more than that of a gosling or a turkey, and I think he must have had the time of his life worrying me night after night every time there was a litter of kittens on the back porch. You may say that I should have learned that the mocking bird was deceiving me. I felt so too, sometimes, but just so surely as I came to this conclusion I would find that some imp had put it into the head of some of my pets actually to get out and lose themselves and when I did not go to the rescue some real disaster was quite sure to happen.

A little later, when the neighbor's guineas became noisy, 
my mocking bird took up their song for a time, singing "potrack" as well as any guinea could.

When the robins are flying northward in great numbers and sing in every tree, my mocking bird seemingly believes himself to be a robin, but within a week or two he forgets all about this and takes up the song of some other bird. Just now some of the boys have made a peculiar whistle which they are enjoying, and only a day or two ago some one called my attention to the fact that my mocking bird vias imitating this whistle. A few summers ago I arranged for some one to give a certain signal on a police whistle if my number was called, so that no matter where $I$ happened to be I could come to the telephone. It didn't take my mocking bird long to adopt this whistle, and many times he has called me to the phone only to learn that the girl had not whistled for me. I always fancied that he looked at me with a sly wink of amusement every time he saw me come in answer to one of his calls.

The mocking bird is much like the blue jay in size and build, the chief difference being that the mocker is more slender and altogether a lighter bird. He frequents hedges and brushy fence rows, much as does the jay; and, strange as it may seem, I have known people to confuse the two. He feeds on seeds, berries, fruits, and insects when he can get them, seeming to prefer grasshoppers and crickets, though he eats many caterpillars and even cotton boll weevils and other beetles. He has been a hunter so long that he has learned the way of the wild folk. Mcny an hour I have watched him in my front yard during the hot summer. He runs across the lawn for perhaps eight or ten feet, then suddenly stops and throws up his wings, sometimes repeating this action two or three times. There is a con- 
spicuous white spot under each wing, and from observing him I have concluded that this maneuver is an attempt to frighten an insect into making a move. Many insects are so colored that so long as they do not move, they are hard for even a bird to see. But among insects there are a great many foolish individuals which, even though they may know the law of the woods, "When in doubt sit tight and keep still," never seem to be able to remember it when danger approaches. My mocker seldom has to throw up his wings many times before some grasshopper is foolish enough to move and then he is sure to disappear down the mocking bird's throat or be carried away to feed the fledglings.

The mocking bird does not confine his song to the mating season. During the hot days of August, when he is tired out from taking care of two or three broods of young, he is usually quiet, but no sooner has he molted and the first cool days of fall have come than he again begins his singing. His fall song is not so rollicking nor so continuous as his spring song, and he seldom sings at night in the fall; but for all that I think his fall song is the sweeter.

The mocking bird migrates little if at all. In the winter he feeds largely on weed seeds and wild berries, but does not sing until the opening of spring. One has no trouble in recognizing the mocking bird even though its most common song closely resembles that of the brown thrasher or some of our other best song birds. The bird resembles the thrushes closely in shape, except for its long tail, and it is nearly their size, but none of the thrushes resemble it closely in color. The catbird, the brown thresher, and the yellow-billed cuckoo are all similar to the mocking bird 
in shape, but there the resemblance ceases. The mocking bird has one characteristic feature, that of jumping up and down while singing, though he seldom does this except in the mating season. At times he flies high in the air and sings as he comes down, often singing until he reaches the ground.

Mocking birds are not found to any great extent along the Pacific coast north of central California, or, coming further east, much north of the Missouri and Ohio rivers, but they have been found occasionally as far north as New England. In my childhood days I saw three or four in southern Iowa.

Without doubt the mocking bird is one of our best American songsters, and a great many bird lovers give him first place among the wild birds of the world, preferring him even to the nightingale. 


\section{XLVII}

\section{SALLY THE HOUSE WREN}

TN England there is a little brown bird known as the 1 Jenny Wren, which has a "stickup" tail and carries itself in a pert, attractive, and characteristic way. We have a number of wrens in America, all of them about the shape of the Jenny Wren, some of them larger and some smaller, but none of them large birds. In most of our States we may find the long-billed marsh wren among the rushes bordering ponds, lakes and streams. This bird is shy, and a person has to be keen to see it. It nests among the reeds and feeds on insects and worms. Its color is cinnamon brown with a whitish streak down the back. It is recognized as a wren by its "stick-up" tail. The shortbilled marsh wren also lives in swamps, but it may be easily identified by the lack of a long bill and by the upper parts being streaked all over.

The most common wren found over the northern part of the United States and the one most widely known is the house wren. I suppose because our forefathers had always known the Jenny Wren at home, and noted the similarity of these tame little songsters to it, they called them jenny wrens. Even now most people do not know we have no jenny wrens. This bird is a delightful songster and very tame. It almost always nests about our houses, and if there is a knot hole in the weather-boarding it is quite sure to build in the house. 
I tell the story of Sally the house wren, an old friend of my boyhood days, because Sally was such a shrewd, bright, pert little mother and was so typical of the family that her story. will give a good idea of wrens in general.

One day late in April I was visiting my old uncle, David Halferty. I liked to visit there, for Uncle Dave was a most interesting story-teller and Aunt Polly was a master hand at fishing. I thought their house was the most beautiful in all the world, and it was situated in the only spruce grove I ever saw in my childhood days. The spruce had been set out; but those who planted them had been wise enough not to put them in straight rows, so no one would have known that they had not come up themselves.

Another interesting thing to me was their well. Our well at home was properly covered with a platform on which was a pump, and when we wanted water we simply pumped it. The same was true of all the neighbors' wells, but Uncle Dave's well was different. It was some fortyfive feet deep, had a beautiful old well house over it, and the water was drawn with a windlass and two buckets. One of the first things that always happened when I reached that place was that I suddenly became thirsty and ran to the well for the novelty of pulling up a great brimming pail of water and watching the other pail go down and sink out of sight in the depths below. Another attraction was that the only hammock I had ever seen was stretched between two of these great spruce trees, and a boy was free to play in it as much as he pleased.

I went over to Uncle Dave's early one morning in spring. As usual, Uncle Dave took it upon himself to entertain me until dinner by showing me about the place 
and telling stories. Aunt Polly and I were to go fishing in the afternoon. We had chored about the barn and were on our way back to the house when we were both startled by the rollicking song of a wren. "Well," said Uncle Dave, "I do believe Sally is back; let's go and see," and he led the way to the well. Uncle Dave leaned over the well and called, "Sally, Sally." Quick as a wink the bird darted to his side, scolding, twittering, and fussing with all her might. He stood there and smiled until she became quiet and then called "Sally," and the whole thing started over again. It seemed that this little songster knew her name and resented it.

It had started in this way. Two years before, this wren had decided to set up housekeeping in the roof of the well house. Day after day she and her hard working husband carried sticks by the hundred and piled them in the corner of the well-house rafters, and evening after evening Uncle Dave threw them away, for he was equally determined that she should not nest in the well house, lest the sticks and feathers flutter down into the water. Some whim caused him to begin calling her Sally, and scolding her every time she came around the well. Persistent little vixen that she was, in spite of his efforts she raised three broods of young in the very spot where she placed her first sticks. She became so furious at his throwing away her sticks that he could not come near the well without her flying into his face scolding and pecking like a little demon, although she never bothered anyone else. This pleased Uncle Dave so much that he finally surrendered and allowed her to have her way. As the summer wore away and her nest was not disturbed any more, her resentment seemed to settle around the use of the name Sally, 
and nothing delighted Uncle Dave more than to call "Sally," and have her fly around his head and scold.

Sally, like all of her tribe, was a tireless worker. When nesting time came she seemed to carry sticks for the pure pleasure of it. She would fill holes that would hold a peck or more with sticks without paying the least attention to the order in which they were placed, even though she finally built her nest in a different place entirely. There were many osage orange (bois d'arc) hedges in the country, and Sally gathered the thorny twigs that had been trimmed from these hedges the previous year. These sticks were never less than six inches long, and often she would carry pieces eight or ten inches long. Her nest was usually constructed almost entirely of these thorny sticks and was eight or ten inches in diameter and four or five inches deep. When this huge pile of sticks was in shape she carried straws, dry grass, and hairs and built rather a large nest of these inside of the stick nest. She finished with a lining of feathers gathered from the poultry yard. The nest was so built that the sticks covered the top as well as the bottom, leaving only a small hole for entering.

Sally nested in this well house for seven years and there were few available spots in it where she had not piled sticks some time or other, though in the end the old nest was usually repaired and used again. I became so interested in her that I determined to have some wrens of my own. So I found two or three bleaching horseheads which I put in trees in various parts of the yard, and every year a pair of wrens nested in each of these skulls. The hole where the spinal cord had entered the head was used as an entrance and the nest was built where the brain had been. 
An interesting thing about these nests was that the birds would spend three or four days piling sticks here and there until they became satisfied that they had done their duty. Then they carried just enough hairs and feathers into the skull to make a snug warm nest without attempting to take any sticks in at all. I never could understand why they should carry to such places a lot of sticks which they could never use.

Sally always looked upon the kitchen garden as her special domain, and made it a business to attack on sight any other bird that dared enter its sacred precincts. This garden was a full hundred yards from her nest, but experience taught there might be luscious cabbage worms on every head of cabbage or bunch of lettuce in that garden, and from dark till daylight there were seldom fifteen minutes she was not to be seen searching those plants for worms.

Sally usually laid seven eggs at a clutch, though one time I found nine in a nest. As the eggs almost always hatch, it is no wonder that Sally and her husband had to visit the cabbage patch frequently. They became so tame that they went about their household duties without paying the least attention even tho I was standing within ten feet. The hammock was not twenty feet from the well and it was interesting to lie there and count the worms carried to the nest in an hour, and to learn what kinds they were. Sally fed her young three or four different species of "measuring worm," caterpillars, at least two varieties of cut worms, an occasional grasshopper, and perhaps a few other small insects, but her main reliance was on cabbage worms. Five times out of six she would bring a green one to her young. A fair estimate of the number 
of worms carried to the nest, based on counts made a large number of times, was a little more than one worm every three minutes. Often they would average a worm a minute for an hour or two. Usually the babies in the second brood received more food than those in the first, not because the old birds were more fond of them, but because food was more abundant at that time. When we think of those birds feeding their young ones worms every three minutes for hours every day over a period of at least three weeks, we can get some idea how beneficial they were to the garden. This means that for every brood of baby wrens raised near a garden thousands of worms are destroyed, to say nothing of what the old birds themselves eat. We never had to pay any attention to cabbage worms in our garden, for I had places in the yard where at least five pairs of wrens nested every season.

I have said little about Sally's husband, but he was an important member of the family. He was a jovial, gallant husband, proud of his family and jealous for their safety. He did the singing, but he nevertheless did a fair share of the work. When his mate began sitting he sang more than ever. Perched on a branch near the nest he fairly laid himself out to excel all other wrens in the vicinity. Should another wren sing too well, he would attack him at once and a battle royal was sure to follow. When he had succeeded in chasing his fancied rival away, he came back with a more exalting song than before; but he never became so busy with singing and fighting that he failed to slip away every little while and catch a worm for his wife.

The wren does not usually come north until danger of frost is past, but when he does come no bird is more full of song. Some claim that the male comes first and begins 


\section{KNOWING BIRDS THROUGH STORIES}

nest building within a few days. Others claim that they come together. I have known wrens to begin building the day they arrived.

When the brood leave the nest, they follow the parents through the bushes and garden, seldom more than a few feet behind. For once the father is silent, seeming to realize that their safety depends on their moving unseen until the young are better able to fly. It is interesting to see how eager the young birds are to eatch their first worm. At first the parents catch the worms, and give them to the youngster that is nearest. Within a day or two the parent finds the worm, but leaves it for the youngster to catch. Within a week or two the young birds have completed their education and are left to shift for themselves. Then the parents return to the nest to rear a new brood.

Sally's plucky temper, coupled with the inborn hatred for the race of cats, finally brought about her undoing. She felt it was her duty to chase all dogs and cats out of the neighborhood of her nest. Usually wrens are content with scolding and complaining whenever a dog or cat comes near, but Sally came to the point where she did not hesitate to fly straight into the face of a cat or dog, and usually the astonished beast would run. One day she became too bold and reckless. Her last brood had been flying only a day or two and were not very sure of their wings. Doubtless she was unusually anxious to drive away the old cat that came to sit on the front door step. She chased it around the house, but that did not satisfy her. Finally the outraged cat stopped, crouched, and as Sallie swooped struck her with his paw and before any one could interfere she was no more. 


\section{XLVIII}

\section{THE BROWN CREEPER}

TOT many days after Creepy appeared on the willow 1 tree I was surprised to see a deep-brown bird scarcely as large as he alight at the bottom of this tree and begin hunting over its surface in much the same way my nuthatch had done, except that he started at the bottom and rapidly ran up instead of going down headfirst. Of course I was interested because these two birds were so strangely alike and yet so absolutely different.

A pair of these brown creepers, for such they were, took up their abode in our yard and orchard, hunting over the various trees but preferring the willow to any of the others, though they hunted the pecan tree and the great transcendent crabapple from bottom to top almost every day. It has always seemed strange to me that these birds will hunt the same tree over perhaps half a dozen times every day for weeks and yet always find some food every few moments.

Many insects lay their eggs in the rough bark of trees and many little creatures hide there in the fall in order to get some measure of protection during the winter. Of course they are colored nearly like the bark, and undoubtedly are growing to look more like the bark every generation, for only those that most closely resemble the 
bark in which they hido escape the sharp eye of the birds, and naturally their offspring resemble them. In this way nature is always busy helping the creatures adapt themselves to the hard situation in which they find themselves. The strange thing is that any of these insects escape. I am sure my willow tree was hunted over regularly a dozen times every day for months not only by the brown creepers and the white-breasted nuthatch, but also by a dozen or more black-capped chickadees and at least one pair of downy woodpeckers, with a flicker and an occasional hairy woodpecker for good measure.

The brown creeper appeared to be the most expert of them all in creeping over trees and gathering insects. He certainly moved much more rapidly over the tree. In fact, he seemed fairly to run as he went about his work, occasionally stopping long enough to give a happy littlo chirp.

These birds were jolly little creatures, not in the least selfish or ill natured; for should the chickadees or the nuthatch appear on the tree when the creepers were there, they made no protest whatever, but all worked together, each willing to take what he could find, doubtless feeling that the bounties of nature belong to all alike and that the one who is the most industrious will win in the end. As I stated in the last story, the nuthatch seldom worked on anything but the trunk, leaving the limbs for the chickadees; but this was not true of the brown creeper. He would often run along on the under side of limbs, looking almost like a mouse running across the top of a beam, so rapidly did he go, yet he always kept a sharp lookout for anything to eat.

He seemed methodical in his work, usually going round 
and round his tree, though sometimes he hunted in a straight line up the trunk and then flew to the bottom and started again at another place. He did not hop or hobble about, as does the woodpecker; he was far too nimble for that.

Many of my readers may find it difficult to locate this bird or at least to examine him well, because he is shy. It is not so much that he aroids our presence as that he does not like to be seen. He may be hunting on a tree within ten feet of you and yet you never suspect his presence, for he will be working on the opposite side of the tree, stopping each time just before coming around far enough to be seen.

As my bedroom window was only ten or fifteen feet from the trunk of the willow, this was a good place from which to watch this bird. He was dark brown above, showing a slightly reddish shade, each feather being streaked centrally with whitish, although this blended into the brown. The rump was rufous and the under parts were almost pure silky white, and there was a white streak over each eye and a few whitish streaks about the ear coverts. The edges of the tail feathers were wood-brown, and there was a pale buffish white bar across each wing. He was about five and a half inches long from the end of the long, sharp, slender bill to the end of the tail. The bill was about as long as the head.

From this description you should have no trouble in locating this bird and identifying him. If you see one alight on a tree and quickly creep around to the other side, sit down by the nearest tree or stand perfectly quiet, and it will not be long till, noticing everything is still, he will come around to your side of the tree, and doubtless 


\section{KNOWING BIRDS THROUGH STORIES}

will be so intent on his hunting that he will not notice you.

In order to attract these birds, it is well to fasten pieces of suet or bits of fresh meat on the bark of tree trunks. It will not be long until one or another of these little tree hunters will find it, and if you continue to put it out they will soon form the habit of coming for it every day.

This bird remained all winter with us in Southern Iowa, though further north he migrates late in the fall. Of course he is easiest to find in the winter when birds are few and the leaves are off the trees. But if you are sharp-eyed you will find him even in the summer in the north.

Most of my readers are interested in birds' nests, and I have described the nest of most of the birds whose stories I have told because often the finding of the nest leads to the identification of the owner. The brown creeper builds in any available place like a split limb, a cleft in the trunk of a tree, or in the opening beneath a piece of loose bark. The five or six eggs are rather unique in that they are a delicate rosy white marked with brown. He is to be found at some time of the year almost all over the United States. 


\section{XLIX}

\section{CREEPY THE WHITE-BREASTED NUTHATCH}

T WAS a cold morning a few days after the events that 1 led to the feeding of my chickadees that I first met Creepy. I was attracted by a cry of cha-cha-cha-cha-chacha-ank. Looking up I saw a little ashy blue bird creeping about on the old willow tree. He was not much larger than a chickadee and the top of his head and his neck were black, which alone might remind one of the chickadee; but here the resemblance ceased. The under parts of the head and the belly and breast were white. His bill was sharp and unusually long for so small a bird. As I stood watching him, he suddenly stopped in his course down the tree raised his head saucily and looked at me as much as to say, "Who are you? What have you to say about it?"

Doubtless this bird had lived about our house all my life, but for some reason he had never made any impression on me. Possibly the fact that I had recently begun feeding the chickadees had increased my interest in birds and made me notice them where I might not have done so before.

Sleet had fallen the night before and everything was covered with ice except the under side of large limbs and a narrow strip on one side of the large trees. This old willow was a great favorite of mine. When father bought 


\section{KNOWING BIRDS THROUGH STORIES}

the claim and decided on the site of the house he stuck a small yellow willow switch in the ground, remarking that he would soon have shade over the kitchen door. Nothing roots more easily than a yellow willow, and it was not surprising that this twig should have taken root at once and quickly grown into a nice little tree. By the time I was old enough to take notice it was the largest tree in the yard. Its long, drooping twigs furnished the switches that stirred up my memory when I was inclined to depart from the straight way, and its larger branches furnished a proper support for my rope swing, while there were always several birds' nests higher up. It was the first tree to bloom in the spring and it filled the house with fragrance and furnished the golden pollen that stimulated the bees to brood rearing. Its bark had grown furrowed and rugged, and provided the best place imaginable for insects to hide over winter.

This white-breasted nuthatch (for that is what he was) evidently had come to this willow as a last resort in hopes of finding some breakfast. When I first saw him he was under a large limb just starting down the trunk of the tree with his head downward. I was dumbfounded to see a bird sit, apparently perfectly comfortable, on the side of a tree with his head down and especially to hear him singing as if he enjoyed the situation. Tho on my way for a load of wood, I stopped to watch the unique sight. This bird was moving over the trunk of the tree prying into every nook and crevice, picking up a morsel here and another there, as busy as could be. He worked his way down the tree until he reached the edge of the snow and then with a "cha-cha" flew to join the chickadees in the garden. 
When I fed these birds I noticed he was still with them, and I was not long in discovering that they were really chums, that he and another of his kind were to be found with this flock of chickadees almost any time in the day. When their crumbs were scattered on the snow, Creepy did not hesitate to feed with them, although at other times he seldom alighted on the ground. Chickadees hunt the trees for insects and their eggs as carefully as do any of the woodpeckers or nuthatches, but Creepy and these birds hunted together in perfect harmony and never seemed to infringe on each other's territory. The top of the tree and the branches evidently belonged to the chickadees while the trunk was the special property of the nuthatches.

Creepy invariably alighted on the tree pretty well up and hunted downward, which means that his head was down the greater part of the time. These birds are even more expert at crawling about on the bark of a tree, taking any sort of position imaginable, than are the woodpeckers. Their toes are long and stout and are armed with powerful claws which enable them to hold firmly to the side of any tree. I have seen one of these birds sitting on the side of a tree with its head upward and then without letting loose of the tree at all with one foot, turn completely around until the head was downward, the foot still pointing upward. To me it is as marvelous to see one of these birds turn almost completely around without changing a foot as it is to see the owl turn his head more than half way round to gaze at me.

These birds are found practically everywhere, though they are never numerous. If you look sharply you will have no trouble in locating them in the winter time when the trees are bare and other birds are scarce. If they 


\section{KNOWING BIRDS THROUGH STORIES}

migrate at all it is only occasionally and for a short distance. They are smaller than any of the woodpeckers and are not so brilliantly marked. The bill is more slender, and you should have no trouble in identifying them by this mark alone.

Creepy and his wife hunted through our orchard, garden, and yard until spring, when they decided that the old willow tree that had proved their salvation in the winter was the most satisfactory place for their summer home. They selected a limb perhaps four inches in diameter about twenty-five feet from the ground and began the work of pecking a hole in it. They worked with a will and made the chips fairly fly for three or four days. They were a happy little pair, both working with a will, congratulating each other every few moments. These birds seemed even more expert at chiseling out a nest hole than the woodpecker; but, unfortunately for me, they made their hole so small that my hand would not go into it. A rye straw pushed in, however, showed that it was at least fourteen inches deep. I do not know how many eggs these birds laid, but five to eight is the usual number, and they are of a pearly white color, slightly marked with lilac or rusty yellow.

No bird could have been a better husband than Creepy. He was a hard worker, doing fully as much of the nest making as his wife, fluttering over and hopping about her while she worked. When the hole was several inches deep and his wife was taking her turn at drilling he would peep in with the greatest concern if she stayed too long, and when she was sitting he remained near by to keep her from becoming lonesome, not forgetting to feed her every little while. When she left the nest for a little airing, he mani- 
fested his delight by strutting about and hopping over her, then rushing for a beetle to feed her.

Early in June I became aware that there were young birds in the nest, for the parents were kept busy carrying food from morning till night. They not only fed caterpillars and small insects that they caught on the trees, but did not hesitate, when other food was scarce, to alight on the ground and hunt among the leaves and grass. In the winter we had formed the habit of putting out bits of suet and in warmer days bits of fresh meat for these birds, which came to look for this food every day. We ceased doing this in the spring, but now when they had a family to feed these birds appreciated a piece of suet as much as in the winter. By the middle of July the young birds left the nest. Creepy continued to feed his children for some time and seemed proud of them. They raised five to maturity. 


\section{$\mathbf{L}$}

\section{THE BLACK-CAPPED CHICKADEE}

NE cold winter day I had been kept in the house all morning. My health had never been very good and I had been suffering considerably from sore throat, rheumatism, etc. The most trying thing in the world for a boy is to be kept indoors where it seems to him nothing of any importance is going on and he knows there is so much of interest outside. I was disconsolately looking out of the window at the drifts of snow when mother stepped to the door and threw out the crumbs she had brushed from the table. The wind whirled these crumbs over the snow until they were caught in an eddy near my window. Almost immediately a flock of half a dozen jolly little birds with black heads, tails and wings alighted on the snow and began picking up these crumbs and singing "Chick-a-dee-dee-dee-dee" as happily as if they had been invited to a banquet. Indeed they might well have thought they had been invited to a banquet, for the winter had been so cold and the snow so deep that it must have been hard indeed to find food.

These were chickadees. They said so themselves, as plainly as could be, and then to prove the matter I asked mother and she confirmed their word. I watched them until they had cleaned up the crumbs and marvelled at 
their peaceful ways and the liberality with which they shared this meager meal. There was no quarreling over which should get the best crumbs, and no matter how anxious a bird was to feed he never failed to stop and sing his thankfulness every few moments. When the last crumbs were gone, away they whirled into the garden and began picking over for the thousandth time every old sunflower head and Indian lettuce plant in sight. I then conceived a great admiration for these happy little birds. Talk about bravery, I know of nothing more courageous than these tiny feathered creatures which defy the winter's snow and ice where the temperature falls to twenty or more degrees below zero rather than forsake the home they love. I have never seen a winter so cold that many chickadees did not remain with us, and I have never seen them when they were not apparently as active and as happy as in the summer time.

That was the winter I have already mentioned in this book when the snow was so deep that we could drive anywhere we pleased over fences and creeks. This incident of the crumbs gave me an idea and, after talking the matter over with mother, she gave me permission to feed these birds every day. So after that memorable forenoon the crumbs from the table were always placed either on the window sill or scattered on the snow. Somewhere, I read a little story about putting out a sheaf of wheat for the birds at Christmas, but it seemed to me that if this was a fine thing for Christmas it must be equally desirable every day. We did not have any sheaves of wheat, but our barn floor was usually covered several inches deep with chaff and in this there was not only an abundance of timothy and clover seed but a good many grains of wheat as well. After 
the day mentioned above it was our practise not only carefully to save the crumbs from the table but to get chaff from the barn floor and scatter it over the snow. It was surprising how soon these little birds came to expect their food and how tame they became. After breakfast and after dinner they were sure to be sitting about near the house waiting for their crumbs. When they were brought these birds would come in a troop and clean them up.

Gradually I began to put little bits of suet and pieces of bread, oat meal, etc., on the window sill, and it did not take the birds long to find this treasure. Sometimes ten or twelve birds would be feeding on the window sill at once, and they paid no attention to us even tho we came within two feet of them on the other side of the glass. Every day the flock increased in size.

But chickadees were not the only birds that came. There were at least twc or three other birds that frequently accompanied the chickadees and apparently lived with them. These were the ruby-crowned and the golden-crowned kinglets. The kinglets are smaller than the chickadee, but can be distinguished from them by the color of the head and wings. The head of the chickadee is black, while the kinglets have either a yellow and orange or a scarlet crest on the head, the rest of the head being more or less brown. The white-breasted nuthatch was also often in the company. We called all of them "snow birds," which is their common name over much of the country.

These birds feed almost entirely on weed seeds and insects, but of course they will feed on crumbs or even wheat, especially in the winter when other food is scarce. They are valuable because they eat many times their own weight in weed seeds, as well as many noxious insects every 
year. There is really no excuse for killing a chickadee, for it not only cheers us on a cold, wintry day, but is always our friend and helper. And it is so small that no one could possibly have any use for it for the table.

As soon as we have the first suggestion of spring, usually in February, the chickadee begins singing a new song, a very sweet "Phoe-e-bee," not at all like the jerky song of the phoebe bird, but to my mind much more like the word. The little call is so seductive that it is no wonder it never fails to win the singer a bride. When she appears, the singer finds that he has several other notes he can perform, especially a catchy yodel of delight.

When nesting time comes they hunt up an abandoned hole made by a woodpecker or a nuthatch, or a natural cavity, or if none is handy, dig one for themselves in a decaying tree, and line it well with moss, fur, feathers, or other soft material. This hole is seldom ten feet from the ground and is often in an old fence post. They lay as many as eight white eggs, lightly speckled with reddish or lilac brown spots. 


\section{LI}

\section{THE BLUE-GRAY GNATCATCHER}

TEAR our grapevine playhouse, where I became ac1 quainted with so many of my birds, early one spring there appeared a little stranger that I at first mistook for a small bluebird. I watched him carefully and finally got near enough to see that he could not possibly be a bluebird, at least not the kind with which I was familiar, for instead of his breast being red-brown and his belly white, his entire underparts are whitish gray. More than that, his tail was black, bordered with white, and even the wings were brownish black, especially toward the tips, which were bordered with blue-gray.

The day was fine and in the open places near the woods there were many swarms of small flies or gnats. This little stranger was busily engaged in catching these insects. He would fly back and forth through the dancing swarm and every time he caught one or more of them. Evidently he was hungry, after his long journey from the great Southland, or possibly he especially liked these gnats. At any rate he spent a full half hour catching gnats without stopping to rest for a moment.

I asked mother what this strange new bird could be, but she was not able to tell me, so the next day we went to the woods together to see if we could find the little 
stranger. Surely enough he was at almost the same spot, feeding on flies. We managed to creep up close enough to see that this bird was not a bright blue, but a gray blue.

When hunting he would fly a short distance this way and a short distance the other, jerking his tail up and down as if it was hard work to keep his balance. In fact, this habit of jerking his tail up and down while flying is one of the easiest ways to identify the blue-gray flycatcher, for few other birds do this. When he alighted, it was on the tip of a twig, and he often hung to the last bunch of leaves rather than light on the twig itself. This is another characteristic of his.

I think I have never seen one of these birds light well back on a limb where he could secure a good foothold, tho others say that he does so. As a result, when he alights on the end of a twig, he has to keep jerking his tail up and down to preserve his balance, and he even finds it necessary to droop his wings to help him cling to the twig on which he roosts. He seldom if ever alights on the ground even to drink and I have never seen him take a bath. When thirsty he sometimes sips the drops of dew from the end of the twigs or of the leaves.

The nest is built of very frail material, and tho the bird is scarcely larger than a house wren the nest seems small even for so tiny a bird. It is built mostly of dried leaves and bud scales, etc., tied together by the silken fibre of plants and flowers and the inner bark of weeds. Lichens are fastened on the outside, while the lining is of moss, down, and horse hairs. It is firmly attached to two twigs, usually near the end of a limb. These birds, living as they do on small insects, many of which breed in the water, 


\section{KNOWING BIRDS THROUGH STORIES}

prefer to live near creeks or ponds and to build in low trees.

Altho they live in most parts of the United States, except the extreme North, they are not common in many places, and their tiny frail nest is difficult to find. They lay four or five white or bluish-white eggs with a few reddish dots at the large end, and often rear two broods each year. As soon as the young are able to fly they hunt with the parents. At such times half a dozen or more may be found in a flock busily engaged catching tiny insects. Their common note is a "Tswee, tswee," but this has a musical tone. They arrive late in the spring and leave early in the fall, and generally spend the winter south of the United States. 


\section{LII \\ THE WOOD THRUSH}

W ing the summer months, I am always impressed with the wonderfully sweet voice of the wood thrush. This bird is more abundant there than in any other place I remember visiting. From five o'clock in the evening until after dark I am especially pleased with his wonderfully musical call, "Chit-a-link, chee-wee-eee." In the morning I listen to this song from daylight until seven or eight o'clock. Sometimes he sings during the day, but his song never sounds so sweet or musical as in the evening.

The wood thrush, or, as the mountain people call it, the "chitalink," is well known as a wonderfully sweet songster even though he sings only a few notes. If he had the wonderful range of the mocking bird, he would outdistance all competitors so far that I am sure we would cease to appreciate many of them as we do now. This bird has several notes, but we usually hear only three or four. Clear and musical as a silvery bell, no matter how often we hear them they never become monotonous or tiresome.

This bird is well named the wood thrush, for he loves the deep woods and means to keep himself concealed therein. So shy is he that when he alights he usually manages to sit near some stump or tree trunk the color of which matches his own so completely that he is difficult to see. 
I find many people who are familiar with this bird's song who do not recognize him by sight because he is so seldom seen, and when he is seen it is seldom while he is singing. In shape he much resembles the brown thrasher or the mocking bird, having the same general conformation of body, but a shorter tail. The color abore is a cinnamon brown, becoming more of a rufous on the top of the head. The rump and tail are more nearly olive, the under parts are white. The breast and the belly are thickly marked with sharply defined spots of a blackish color. These spots never extend to the middle of the throat or back to the vent, however. The sides of the head are dark brown streaked with white, and there are streaks on each side of the throat. He is about eight inches long from the tip of the bill to the tip of the tail. His tail alone is slightly over three inches long.

This wonderful songster was fairly common in our home woods when I was a boy; but I did not know him by sight. I loved his wonderful voice but had no idea to what bird I was listening. It remained for me to come South where these birds are abundant to become acquainted with them at first hand. The wood thrush reaches the north later than most birds. Audubon says that males come first by two or three days, but do not begin their song until their female audience arrives. When they first come they are usually seen in small flocks, but when the females arrive and the courting begins they separate at once.

Their favorite home is in the low bushes and underbrush along streams and on the borders of the forest. If there are any wild grapevines creeping over these trees they are almost sure to select such a location for their home. Early in the morning they come to our gardens and 
orchards in search of food, but they usually retire to the woods when the sun is bright, as they might be seen. However, I have known them to nest and live in our back yard here in Tennessee, and they are abundant even in the rather thickly settled residence district of Asheville, North Carolina. One can hear them practically any day among the trees on the campus of the George Peabody College or of Vanderbilt University in the heart of Nashville. I mention those facts so as not to give the impression that one must always go to the deep woods in order to find wood thrushes.

Their nests are usually built in low bushes, but they choose a bush that is so thick that the nest is not conspicuous. They prefer a place near the water. They construct their nest of leaves, grass, weeds, etc., making a rather beautiful nest. Mud is used in the outer part, but the nest is usually lined with moss and soft fine grass and roots. Four eggs are most commonly laid and these are of a uniform light blue. 


\section{LIII}

\section{THE AMERICAN ROBIN.}

$7 \mathrm{HE}$ snow hed piled deeper, the winds howled more 1 fiercely and the ice on the rivers was deeper than in any year within the memory of the oldest settlers. The fences everywhere were buried beneath piles of glistening white, and to one who did not know better the whole country appeared to be one great field. The crust on the snow was so hard that men drove with team and sleigh anywhere they chose to go orer fences and creeks without the least fear.

Father had bought some timber far down on the Skunk River bottom. One day he decided there would never be a better opportunity to get this wood than while he could load it on a bobsled and bring it home directly across the fields, thereby saving two or three miles. Accordingly, the axes were ground, the crosscut saw filed, and early the next morning the team was hitched to the bobsled, my two brothers and I were tucked in, and we all started for the timber. I was still a child, and my part of the job consisted in piling brush and playing about watching for squirrels. The day was bright and turned out to be warmer than usual. The bobsled was left several rods from where we were cutting timber, so that there would be no danger of trees falling on it. The horses were tied to the sled and plenty of hay and grain heaped in it for them. 
When we stopped for dinner and started toward the bobsled, I was surprized to see a robin sitting on the hay picking at the timothy heads. As I have said, the winter had been exceptionally cold and there was no sign of spring anywhere. My whole experience with robins had led me to take it as a matter of course that they all went South and stayed there till the snow melted off in the spring. When we got closer we found a second robin in the hind part of the sled. I promptly raised the question why the robins had come back so early in the spring. To my surprize, father told me they had not come back at all but had remained all winter deep in the forest, and that they had been feeding on hackberries, weed seeds, and other food to be found there. Since then I have found other robins in the dead of winter and as far north as the middle of the State of Iowa. It seems that robins do not go south because they dread the cold weather but because the food supply will become low and they must seek regions where things are growing or starve.

Over most of our country the American robin is one of the best known and most loved birds. Here again we have fallen into the habit of giving the name of an English bird to one to which it does not belong. The English robin has a red breast and is known all over the continent as robin redbreast. Possibly because our robin has a dull brick-colored breast it has received the same name, but the American bird differs in many respects from the English robin redbreast. In fact, they do not belong to the same sub-family.

Our robins take delight in human companionship, and often nest near houses. The most of the nests I found as a boy were in our orchard; but one year a robin nested in 
a rose bush that climbed over the front porch, and it was there that I had opportunity to learn more about him than ever before. The robin must be the proverbial early bird that catches the worm. At any rate he is up and chirping with the first streak of dawn, struts about on the lawn for a few moments, and before broad daylight is off to a pasture or meadow in search of his breakfast. Alighting on the ground, away he goes hoppety-hop, jumping up and down on the ground as hard as possible, making several hops without traveling more than a foot or two, and then stopping to peer very carefully at the ground near by. I used to wonder why robins travel in this particular way, and it was not until a few years ago that I discovered the secret. I had left the soil in one bench in our greenhouse two years without disturbing it, as I had a number of plants growing there that bloom better the second year than the first. In the spring I decided to mix this soil with fresh soil and to use it in potting young bedding plants.

I went to the greenhouse one morning before sunrise, piled some fresh dirt on a corner of this bench and started potting plants. I had not noticed any angleworms when $I$ began, but in only a few minutes a number were crawling over the surface of the ground, while others were sticking their heads and part of their bodies out of their holes. I had two or three pet baby chickens and thinking they might enjoy some fresh worms for breakfast, I brought them in, intending to let them run over the bench while I worked. I was gone only a few minutes, but when I returned there was not a worm in sight, so I dropped the chickens on the greenhouse floor, where they ran back and forth looking for anything they might find, and I again 
started potting plants. It was only a few minutes before worms were again sticking out their heads and crawling out of the ground. It occurred to me that the jarring of the soil might be painful to those angleworms, so I started to experiment. Waiting until the worms had crawled back into the earth, I took my trowel and tapped here and there near the openings of several holes. I could never tap more than a few times before the worms popped their heads out, sometimes coming completely out and crawling to a place that was less disturbed. About the time I became really convinced that this jarring of the soil was actually painful to these worms and caused them to come to the surface, I happened to look out through the glass and saw a robin hopping up and down on the damp ground. Presently he caught hold of an angleworm and began pulling backward to get it out of the ground. The secret was out! The robin had known better than I that when angleworms are feeding near the surface, as they are early in the morning or in wet times, jumping up and down on the earth will cause them to stick out their heads, and then they become an easy prey. I have watched this with field glasses and in other ways a great many times since, and have become convinced that there is some connection between the hopping of these birds and their feeding on angleworms.

But to return to my nest in the rose bush over the porch. The birds began the nest by bringing fine straw, grass, a few bits of twine string, some tough roots and a few leaves, and weaving all into the form of a strong nest. Then soft mud was brought, so soft that water would run out of it, and was literally thrown into this mass of nest material. When the entire nest was saturated with this 
soft mud, the mother bird hopped into it and wallowed first one way and then another until she had not only pressed this mud well into the nest material, but had shaped it to fit her body. Next, before this was dry, it was lined with soft fine grass, neatly woven together and securely stuck to the mud.

Robins do not require mud in order to build a nest, however. I saw one only recently that had no mud at all in its structure.

When the nest was finished mother robin laid five light greenish blue eggs in as many days and then started sitting. She paid no attention when a member of the family came near. Any of us might walk up within two or three feet of her and stand gazing as long as we chose and she never showed the least trace of fear; but let a stranger come into the yard and she left the nest immediately. I sometimes attempted to show friends how tame the bird was, but I fear many of them thought I had been telling them a fish story rather than a robin story, for I never could succeed in demonstrating the bird's tameness to them; mother robin recognized as fully as I that they did not belong on the place and she was not sure what their motives were.

When the young birds hatched, it was interesting to watch their daily menu. The robin feeds on almost anything except carrion. Early in the morning the young birds were usually given a breakfast of angleworms with cutworms for dessert. As soon as the sun was well up their diet changed and they began to be supplied with caterpillars of various sorts, an occasional grasshopper, and (when it could be obtained) fresh fruit. Fruit was fed sparingly, however. Even in cherry season, when the 
mother bird is gorging herself every hour of the day on ripe red cherries, her young are given one only occasionally. Evidently, the mother bird feels that worms and bugs are better food for producing growth and feathers.

When the young birds were able to fly, the parents did not give them much of an education. When I think how Sally the Wren would hunt worms and show them to her babies, but would refuse to pick them up herself; and when I remember that the belted kingfisher would kill fish and toss them into the water and make the young kingfisher dive for them, and then gradually begin merely to stun the fish, thus teaching her children how to catch a living, I am convinced that the robin is a poor schoolmaster. She is so concerned with the welfare of her children that she continues to feed them for days and even weeks after they are able to fly. I have seen young birds hopping about on the ground picking up worms for themselves, but still the over-fond parents were hard at work gathering food for them and the greedy little fellows ate not only all they themselves could find but all the parents would bring them.

As cold weather approaches and caterpillars are hard to find, the robins, recognizing that food will soon be growing scarce, fly away to the Southland. I was in Texas one year when the robins came in by thousands and was very much surprized and amused to see what gormands they really are. I had always heard that when some people get away from home they show poor manners. This certainly is true of the robin. In Texas there are a great many "umbrella china" trees which bear large crops of berries about the size of cherries. Most of the native birds do not eat this fruit, but no sooner do the robins reach Texas 
than they go on one long spree. They make straight for the "umbrella china" trees and begin eating the berries. These berries make them as drunk as any old toper ever gets. In fact, they get so drunk that they can neither hop nor fly. They fall to the ground and lie on their side, occasionally feebly fluttering, apparently as happy as any drunkard in his cups. No sooner does the "jag" wear off a bit so that they are able to fly than they go back to the trees and get drunk all over again. Often the natives catch these drunken robins, kill, and eat them, but the other robins do not seem to learn wisdom from this. In fact, they never really sober up until all the "umbrella china" berries are gone. Then they are good citizens until another year comes around.

Robins prefer to spend the winter in the cane brakes along the rivers and swamps from Tennessee southward. On cold days they remain close to or in the cane brakes, but ordinarily they scatter over the woods and fields by day and return to the brakes in the evening to roost.

Being a great lover of fruit, the robin, in the minds of a great many farmers, is a nuisance, and they do themselves great injury by killing him in cherry time. But for every cherry a robin eats he eats hundreds of insects that would have done much more injury than the value of a cherry. 


\section{LIV}

\section{AZURE WINGS THE BLUEBIRD}

$7 \mathrm{HE}$ people who came over in the Mayflower were 1 charmed with a beautiful bird that appeared in the woods about Plymouth early the next spring after their arrival. It was such a sweet, happy little songster and was of such a beautiful brilliant blue that they were as delighted with it as they had been with their own home robin. This bird is about the size of the English robin, and has a dull brick-red breast. Immediately the Pilgrims began calling it the blue robin, and until the present day many of the children in New England know it by no other name.

This is our bluebird, which is found over practically all the Eastern United States. There are, indeed, several species of bluebirds, and the western species are more brilliant in color than the one found in the eastern part of the country, and they have less red or even none on their breast. Nevertheless, all of the species are as much alike as two kinds of horses, and they are all generally known all over the country simply as bluebirds.

When I was a boy we children took keen delight in being the first to see a bluebird or a robin, and it was always an open question which bird would arrive first. In the story of our robin I noted that they sometimes stayed 


\section{KNOWING BIRDS THROUGH STORIES}

all winter in the deep woods along Skunk River. Bluebirds sometimes did the same thing, tho I do not believe as many bluebirds did this as robins. The only bluebird I ever saw in the dead of winter was in the thick underbrush in an oak grove. These oaks did not shed their leaves and consequently made an almost perfect wind break. Brash so thick had grown up under those trees one could scarcely get through it. The last drumming partridge I ever saw killed in Iowa flew into this wilderness of brush and trees, and while we were creeping through the snow looking for it what should we see sitting on a stump but a bluebird, looking like some beautiful blue flower on a background of white. Perhaps the few bluebirds that usually came about our homes the last of February or the first of March had stayed in such places all winter. At any rate it was usually two or three weeks after we saw the first bluebirds before they became common.

Like other children, sister and I always delighted to hunt bird's nests, and the prize of them all was a bluebird's. We had been taught that it was wrong to take the eggs or in any way to break up a nest, and we seldom did so, but we often looked at the eggs and helped feed the young birds. There are some birds that will promptly desert their nest if it is bothered before the eggs are hatched, and there are a few that will even desert their young, but this was not true of mother bluebird. We birds these were, and so seldom touched their eggs or young, but this was not true of mother bluebird. We never hesitated to handle the bluebird's eggs, but we were careful not to do this more than once or twice in any nest, and of course were most careful not to break the eggs. 
The bluebird is one of the sweetest and cheeriest of our song birds. He does not sit on the top of a tree and give a grand concert, as does the brown thrasher or the mocking bird. He merely warbles and twitters as he flies or when he sees his mate; but to my eyes there is no prettier sight than one of these beautiful blue creatures hovering about his mate, fluttering his wings, and carolling his song; and few birds have a sweeter song.

Bluebirds usually come north two or three weeks before they build their nests and so have a chance to select the location very carefully. This they do. I have known a pair of bluebirds to examine more than a half dozen sites, even carrying a few pieces of grass or other nesting material to each before finally settling on a place to build; but I have never seen a bluebird family make a foolish choice. Normally they nest in deserted woodpeckers' holes, or similar hollows in trees, but they are quick to see the advantage of a regular bird house. When we boys in the neighborhood began to construct martin houses the bluebirds usually took possession at once; and as they come north at least three or four weeks earlier than the martins, they often had their nests pretty well constructed when the martins came. If martins had been in the habit of nesting in any locality, they usually entered these houses when they arrived and started tumbling the bluebirds' nests on the ground. Then there was trouble at once. 4 martin is a larger and stronger bird than a bluebird, and one would suppose from watching them fly that they were swifter as well; nevertheless it has been my experience that, at least three times out of five, the bluebird comes out victorious and chases the martins away. This is not always true, however. Milo Lemley, one of my nearest neighbors and 
a boy of about my own age, was somewhat of a genius in building and decorating martin houses. He usually had several in his yard and garden, and it was always my envy that martins nested in every one of these. I especially remember one, a very elaborate martin house with eight or ten compartments in it, and this house never failed to have a pair of martins in each room. The bluebirds never succeeded in driving the martins from any of Milo's houses, and at their place the bluebird's nest nearest to the house was in an old apple tree in the orchard, where a woodpecker had made a hole and built a nest some years before. At our house it was different. The only pair of martins that ever succeeded in gaining possession of any of the houses I put up was the pair that were responsible for the death of Jerry the kingbird. No matter where I put a house, bluebirds promptly took possession of it.

There were battles royal, however, in both places almost every spring; for if a pair of bluebirds got into trouble over a nesting place, all the bluebirds in the neighborhood came to their help, and the same was true of martins. Doubtless more martins lived at Milo's place than there were bluebirds in the immediate vicinity, while at our place the bluebirds were so numerous that enough martins never came that way to outnumber them.

The bluebird lays a beautiful light blue egg. There are usually four or six of these, and the birds generally raise three broods of young in a summer. The father is a model husband; he delights to feed his mate not only during their courtship, but when she is sitting he makes it his business to see that she is well supplied with food; and as soon as the young are hatched, he is so busy all day long catching worms and insects to fill the baby mouths that he doesn't 
have time to sing. For this reason we seldom hear the bluebird's song after the first young are hatched. No sooner does a brood get old enough to leave the nest than the father takes full charge of them, gives them their education, fights for their safety any bird that comes his way, and even goes so far as to drive the house cat from their vicinity. In the meantime the mother bird rests a few days and then begins the task of rearing a second brood. By the time she is sitting again the young birds are usually able to look after themselves, at which time the father, without a day's vacation, returns to his duty of feeding her. In the early spring we often see bluebirds alight on the plowed ground, and if insects are scarce and there is a young family to feed, they may even follow the plow all day long for grubs and worms. By the time the third family is ready to fly it is time to think of the trip to the southland. So the bluebird leads a busy life in the summer.

I was in Texas one fall when the bluebirds began to arrive from the North. They did not come with the joyous song with which they arrive in the spring in the North. Instead they seemed to be dull and sad. They would sit about on trees, occasionally giving utterance to a sad little chirp. Each day they arrived in greater numbers until by the first of November they could be seen by the hundreds any day. At first I thought they were dull because they were tired after their long journey, but as the days wore by and there was no change I became convinced that it was their normal way of acting. Evidently they do not love the Southland as well as their northern home, and feel that they are simply forced to come South by the hard winter. 
The most beautiful of all our American species are the Arctic bluebirds. They live from far north in Northern British Columbia south to Chihuahua and New Mexico. I became acquainted with them in Washington and Oregon. They are a brilliant ultra-marine blue, with lighter blue beneath, and have no red breast.

You will have no trouble in recognizing the bluebird, because it is the only bird that is blue with a red breast. In size it is only slightly larger than a sparrow, though it is plumper and fuller breasted. The only other bird that would possibly be confused with it is the indigo bunting, and it has no red breast, is a slender bird, and is smaller than our bluebird. Besides, it does not come early in the spring and is not so sweet a songster.

\section{Keys to the Families of Passeres}

ALAUDIDE-Larks.

Rather plainly colored birds, with the tarsus rounded behind, the hind toe much lengthened, the bill rather stout, and the nostrils with bristly tufts.

Cotrngrde-Cotingas and Becards.

Plumage usually, at least in part, of bright colors, the tarsus rounded behind, the hind toe not lengthened, and the hind face of the tarsus with numerous small scales.

TyRannide-American Flycatchers.

Dull colored birds of mostly grayish, yellowish, or olivaceous plumage, with the tarsus rounded behind, the hind toe not lengthened, the bill usually flattish, and bristly at base, the hind face of tarsus without numerous small scales.

HiRUNDINIDE-Swallows.

Bill short, broad, and flat, without bristles at base; feet small; tarsus short and sharply ridged behind; the longest primary at least twice as long as the secondaries; plumage often in part metallic.

CINCLIDE-Dippers.

Plumage dull colored, densely downy underneath; tarsus not transversely scaled except at the very lowest part; tail very short; and nostrils linear.

Cram $\approx I D=-$ Wren-tits.

Plumage brownish, not densely downy; tarsus not scaled; tail much longer than wing; nostrils oval.

TURDIDE-Thrushes, Solitaires, and Bluebirds.

Of moderate size, the length of the wing more than 3 inches; tail not longer than the wing; the tarsus not scaled except at the very lowest part; the bill moderately slender, the upper mandible notched near its tip; the tail square or nearly so; and the first primary very short. 
SyLvird E-Warblers and Kinglets.

Small birds of mostly dull colored plumage; the wings less than 3 inches in length; the bill slender; and the first primary very short, about one-third of the longest.

Coerebide-Honey Creepers.

Brightly colored small birds with the bill strongly curved downward from the base, and tail-feathers rounded at tips.

ICTRRIDE-Blackbirds and American Orioles.

Bill straight or nearly so, more or less cone-shaped, and not notched at the tip, the gape without bristles; plumage mostly yellow, orange, black, and white.

FringILlide-Sparrows and Finches.

Bill more or less cone-shaped usually short and stout, the gape with bristles; the third and fourth primaries usually of about the same length; the nostrils concealed by feathers or overhung by a horny scale, or else the cutting edge of lower mandible forming a distinct angle near its base.

TANGARIDA-Tanagers.

Like the FRINGILLIDA, but nostrils not concealed by feathers or overhung by a horny scale; and the cutting edges of lower mandidle not forming a distinct angle near its base.

Motacrllids-Wagtails and Pipits.

Bill relatively slender; claw of the hind toe as long or longer than the toe itself; tertials reaching nearly or quite to the tip of the wing.

COMPSOTHLYPIDA-Wood Warblers.

Small birds, usually under 6 inches in length; plumage usuallv bright-colored; bill not notched nor decidedly hooked at the tip; the second or third primary the longest.

VIREONIDE-Vireos.

Small birds, plumage mostly olive green and gray and white; bill relatively stout, without conspicuous bristles at the base, notched and distinctly hooked at the tip; the basal joint of middle toe united for all its length to the two lateral toes.

LANIIDX-Shrikes.

Plumage gray, black, and white; length about 8 inches or 9 inches: the bill strongly notched and hooked at the tip, almost hawk-like.

Certhima-Creepers.

Size small; plumage, brownish and white; the bill long, slender and curved; tail-feathers stiffened, with lengthened sharply-pointed tips.

BOMBYCILLIDE-Waxwings.

Head crested; bill short and broad at base, the length of the keel of the lower mandible decidedly less than the width of the bill at base; the outermost primary less than half as long as the primary coverts; feathers between the eyes and bill dense and velvety; plumage generally soft and its colors blended.

Prizogonatide-Phainopeplas.

Like the BOMBYCILLIDs, but with the outermost primary much longer than the primary coverts, and the feathers of the space between the eye and the bill not dense and velvety.

PARIDR-Titmice and Chickadees.

Small birds of mostly black, white, and gray plumage; bill short and stout, not notched at the tip, the nostrils more or less covered with bristly feathers; the basal joint of middle toe usually united for all of its length to the two lateral toes.

Troglodytide-Wrens.

Bill lengthened, rather slender, and not hooked at tip; nostrils not covered with feathers and bristles; the basal joint of middle toe united for all of its length to the two lateral toes; plumage usually brown or brownish and white. 


\section{KNOWING BIRDS THROUGH STORIES}

STURNIDA-Starlings.

Plumage more or less metallic; bill more or less flattened at the base of the upper mandible; wings long and pointed, the first primary less than half an inch long.

SitTIDE-Nuthatches.

Small birds with slender bills; nostrils more or less covered with a tuft of bristly feathers; wings long, the first primary less than an inch in length; the tail short; the hind toe longer than the outer anterior toe.

Corvidx-Crows and Jays.

Size moderate or large, the length of wing more than 4 inches; the nostrils quite covered with a tuft of bristles, or else circular, or else the base of culmen broad and flattened feet and legs stout; tail more or less rounded; first primary one-half inch or more shorter than the second.

MIMIDE-Thrashers and Mocking Birds.

Size moderate, the birds from about 8 to 12 inches in length; tail rather long and decidedly rounded; length of wing more than 3 inches; base of upper mandible not flattened; nostrils not circular nor covered with bristly feathers; bill not stout, but moderately long.

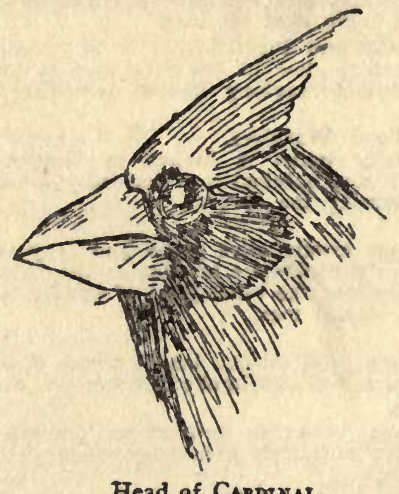

Head of Caxprnar. 


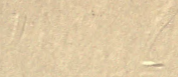


THIS BOOK IS DUE ON THE LAST DATE STAMPED BELOW

AN INITIAL FINE OF 25 CENTS WILL BE ASSESSED FOR FAILURE TO RETURN THIS BOOK ON THE DATE DUE. THE PENALTY WILL INCREASE TO 50 CENTS ON THE FOURTH DAY AND TO $\$ 1.00$ ON THE SEVENTH DAY OVERDUE.

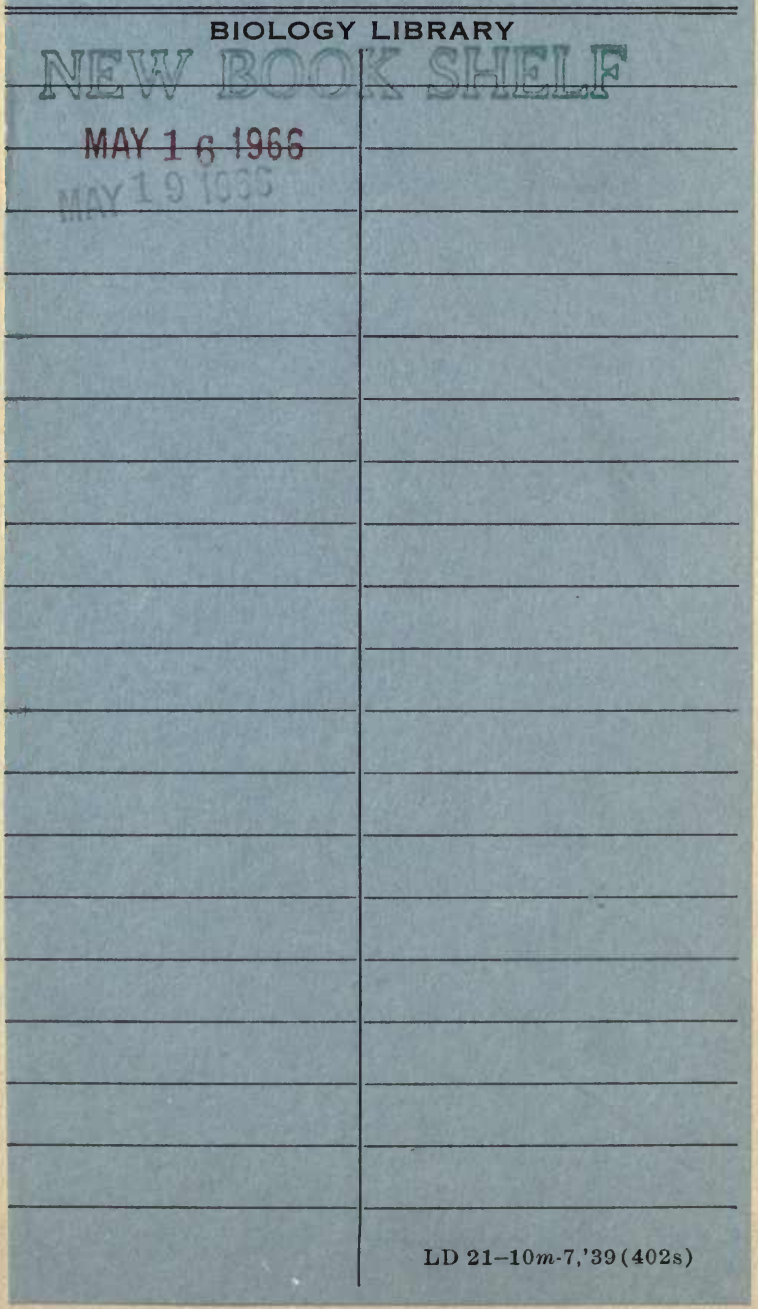




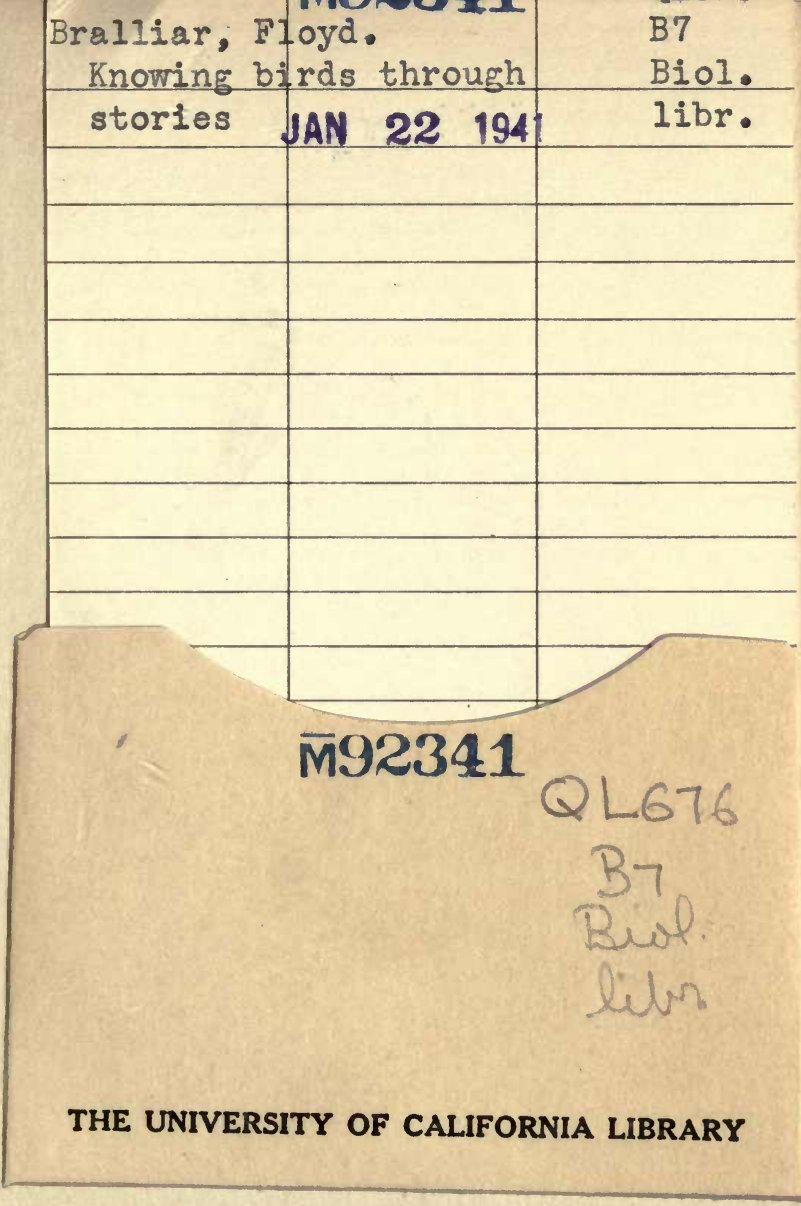


